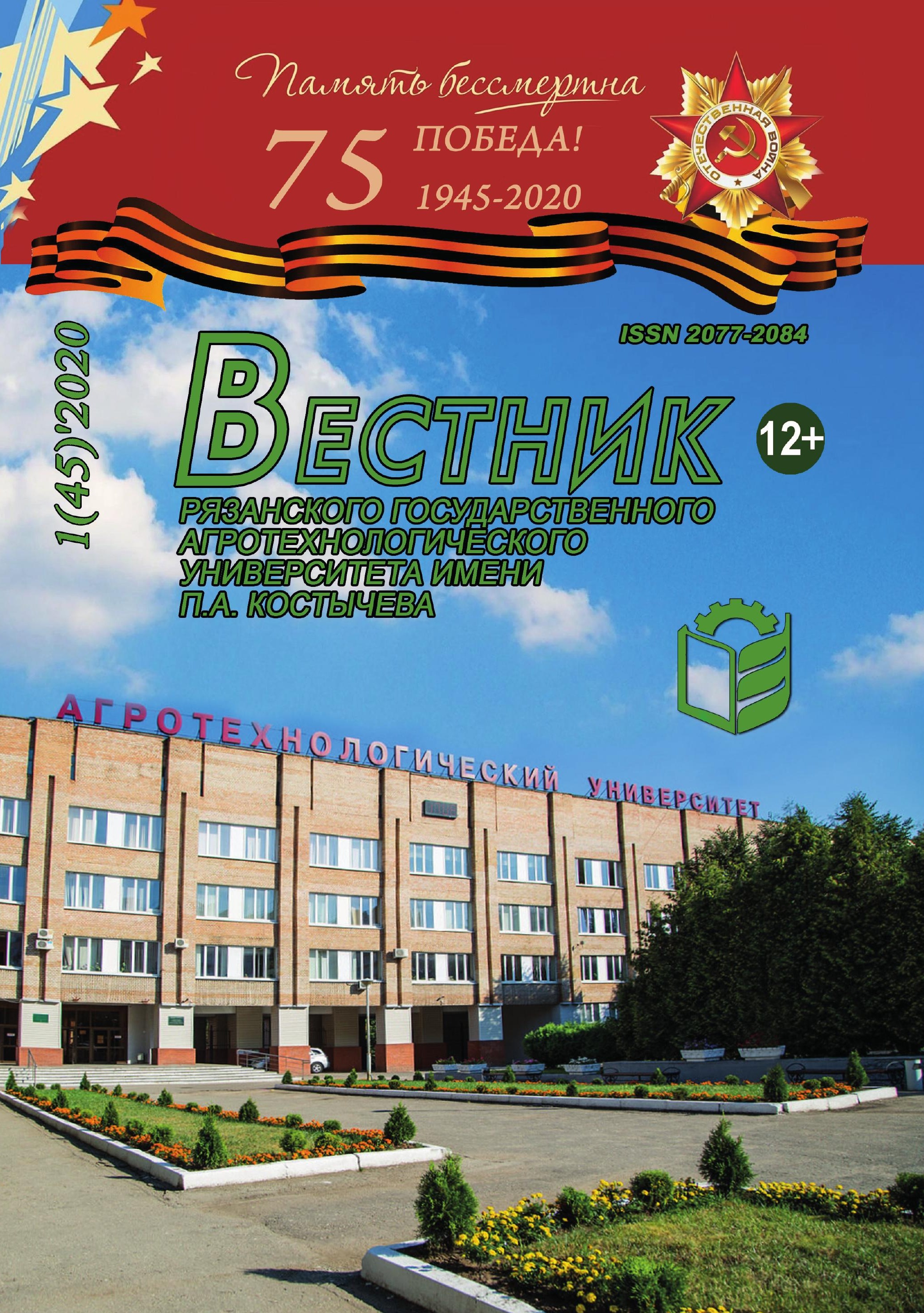

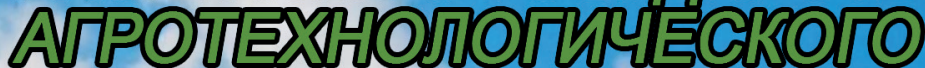

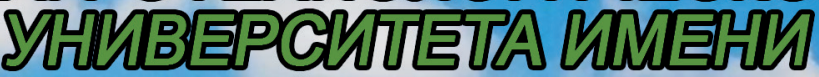
ПIA RSOCIIMEDEA 


\section{ВЕСТНИК \\ РЯЗАНСКОГО ГОСУДАРСТВЕННОГО \\ АГРОТЕХНОЛОГИЧЕСКОГО УНИВЕРСИТЕТА имени П. А. КОСТЫЧЕВА}

Входит в Перечень рецензируемых научных изданий, в которых должны быть опубликованы основные научные результаты диссертаций на соискание ученой степени кандидата наук, на соискание ученой степени доктора наук, по научным специальностям и соответствующим им отраслям науки

05.20.01 - Технологии и средства механизации сельского хозяйства (технические науки)

05.20.01 - Технологии и средства механизации сельского хозяйства (сельскохозяйственные науки)

05.20.03 - Технологии и средства технического обслуживания в сельском хозяйстве (технические науки)

06.01.01 - Общее земледелие растениеводство (сельскохозяйственные науки)

06.01.02 - Мелиорация, рекультивация и охрана земель (сельскохозяйственные науки)

06.01.04 - Агрохимия (сельскохозяйственные науки)

06.02.05 - Ветеринарная санитария, экология, зоогигиена и ветеринарно-санитарная экспертиза (биологические науки)

06.02.05 - Ветеринарная санитария, экология, зоогигиена и ветеринарно-санитарная экспертиза (ветеринарные науки)

06.02.07-Разведение селекция игенетика сельскохозяйственныхживотных (сельскохозяйственные науки)

06.02.07 - Разведение селекция и генетика сельскохозяйственных животных (биологические науки)

06.02.10 - Частная зоотехния, технология производства продуктов животноводства (сельскохозяйственные науки)

\section{Научно-производственный журнал \\ Издается с 2009 года \\ Выходит один раз в квартал \\ №1 (45), 2020}

Учредитель - ФГБОУ ВО «Рязанский государственный агротехнологический университет имени П. А. Костычева»

СОСТАВ

редакционной коллегии и редакции журнала «Вестник РГАТУ»

Главный редактор

Н. В. Бышов,

д-р техн. наук, профрессор
Заместитель

главного редактора

Л. Н. Лазуткина

д-р пед. наук, доцент
Технический редактор

М. Ю. Пикушина, канд. эконом. наук, доцент

\section{Члены редакционной коллегии: \\ Сельскохозяйственные науки}

Л. Д. Варламова, д-р с.-х. наук, профессор

М. А. Габибов, д-р с.-х. наук,профессор

В. В. Калашников, д-р с.-х. наук, профессор

О. И. Кальницкая, д-р вет. наук, доцент

С. А. Клементьева, д-р биол. наук

А. А. Коровушкин, д-р биол. наук, профрессор

А. В. Коршунов, д-р с.-х. наук, профессор

Я. В. Костин, д-р с.-х. наук, профессор

Н. А. Кузьмин, д-р с.-х. наук, профессор

В. И. Лебедев, д-р с.-х. наук, профессор

Ю. А. Мажайский, д-р с.-х. наук, профессор

В. П. Максименко, д-р с.-х. наук, профессор
Н. И. Морозова, д-р с.-х. наук, профессор

М. Д. Новак, д-р биол. наук, профессор

А. И. Новак, д-р биол. наук, доцент

Г. В. Ольгаренко, д-р с.-х. наук, профессор

А. Н. Постников, д-р с.-х. наук, профессор

В. Г. Семенов, д-р биол. наук, профессор

Д.И. Удавлиев, д-р биол. наук, профессор

Р. Н. Ушаков, д-р с.-х. наук, профессор

Г. Н. Фадькин, канд. с.-х. наук, доцент

Л. А. Храброва, д-р с.-х. наук, профессор

А. Ф. Шевхужев д-р с. -.Х. наук, профессор

\section{Технические науки}

С. Н. Борычев, д-р техн. наук, профессор

П. П. Гамаюнов, д-р техн. наук, профессор

И. К. Данилов, д-р техн. наук, доцент

М. Ю. Костенко, д-р техн. наук, доцент

В. И. Криштафович, д-р техн. наук, профессор

Г. К. Рембалович, д-р техн. наук, доцент

А. П. Савельев, д-р техн. наук, профессор

О. В. Савина, д-р с.-х. наук, профессор

И. А. Успенский, д-р техн. наук, профессор

М. Н. Чаткин, д-р техн. наук, профессор

Компьютерная верстка и дизайн - Н. В. Симонова

Корректор - Е. Л. Малинина

Перевод - В. В. Романов

Адрес редакции: 390044, г. Рязань, ул. Костычева, д. 1., ауд. 103, тел. 8(4912)34-30-27, e-mail: vestnik@rgatu.ru Тираж 700. Заказ № 1447. Дата выхода в свет 27.03.2020г.
Свидетельство о регистрации СМИ ПИ № ФС77-51956, выдано Федеральной службой по надзору в сфери связи, информационных технологии и масовых коммуникаций 29 ноября 2012 г. О. Костычева 1. ауд. 103. Цена издания 185 руб. 50 коп. Подписной индекс издания в катологе "Пресса России" 82422 


\section{RYAZAN STATE AGROTECHNOF OLOGICAL UNIVERSITY \\ Named after P.A. Kostychev \\ Scientific-Production Journal}

It is included in the list of peer-reviewed scientific publications, which should publish the main scientific results of dissertations for the degree of Candidate of Science, for the degree of Doctor of Science, on scientific specialties and their respective branches of science:

05.20.01 - Technologies and means of agricultural mechanization (Technical Sciences)

05.20.01 - Technologies and means of agricultural mechanization (Agricultural Sciences)

05.20.03 - Technologies and means of technical maintenance in agriculture (Technical Sciences)

06.01.01 - General agriculture, plant growing (Agricultural Sciences)

06.01.02 - Irrigation, land reclamation and land protection (Agricultural Sciences)

06.01.04 - Agrochemistry (Agricultural Sciences)

06.02.05 - Veterinary sanitation, ecology, zoo hygiene, and veterinary-sanitary expertise (Biological Sciences)

06.02.05 - Veterinary sanitation, ecology, zoo hygiene, and veterinary-sanitary expertise (Veterinary Sciences)

06.02.07 - Breeding, selection and genetics of farm animals (Agricultural Sciences)

06.02.07 - Breeding, selection and genetics of farm animals (Biological Sciences)

06.02.10 - Private livestock, technology of livestock products production (Agricultural Sciences)

Issued since 2009

ssued once a quarter

\#1 (45), 2020

Founder - FSBEI HPE "Ryazan State Agrotechnological University Named after P.A. Kostychev"

\section{Editor in Chief}

N.V. Byshov,

Doctor of Technical Science, Full Professor
"RSATU Herald" EDITORIAL STAFF

\section{Editor in Chief Deputies}

L.N. Lazutkina,

Doctor of Pedagogical Science,

Associate Professor

Editorial Staff:

Agricultural Science

\begin{abstract}
L. D. Varlamova, Doctor of Agricultural Science, Full Professor
M. A. Gabibov, Doctoror of Agricultural Science, Full Professor

V. V. Kalashnikov, Doctor of Agricultural Science, Full Professor

O. I. Kaliczkaya, Doctor of Veterinary Science, Associate Professor

S. A. Klementyeva, Doctor of Biological Science

A. A. Korovushkin, Doctor of Biological Science, Full Professor

A. V. Korshunov, Doctor of Agricultural Science, Full Professor,

Y. V. Kostin, Doctor of Agricultural Science, Full Professor

N. A. Kuzmin, Doctor of Agricultural Science, Full Professor

V. I. Lebedev, Doctor of Agricultural Science, Full Professor

Y. A. Mazhayskiy, Doctor of Agricultural Science, Full Professorof

V. P. Maksimenko, Doctor of Agricultural Science, Full Professorof

N. I. Morozova, Doctor of Agricultural Science, Full Professor
\end{abstract}

M. D. Novak, Doctor of Biological Science, Full Professor

A. I. Novak, Doctor of Biological Science, Associate Professor

G. V. Olgarenko, Doctor of Agricultural Science, Full Professor

A. N. Postnikov, Doctor of Agricultural Science, Full Professor

V. G. Semenov, Doctor of Biological Science, Full Professor

D. I. Udavliev, Doctor of Biological Science, Full Professor

R. N. Ushakov, Doctor of Agricultural Science, Full Professor

G. N. Fadkin, Candidate of Agricultural Science, Associate Professor,

L. A. Khrabrova, Doctor of Agricultural Science, Full Professor, A. F. Shevkhuzhev, Doctor of Agricultural Science, Full Professor,

\section{Technical Science}

S. N. Borychev, Doctor of Technical Science, Full Professor P. P. Gamayunov, Doctor of Technical Science, Full Professor

I. K. Danilov, Doctor of Technical Science, Associate Professor

M. Y. Kostenko, Doctor of Technical Science, Associate Professor

V. I. Krishtafovich Doctor of Technical Science, Full Professor,

G. K. Rembalovich, Doctor of Technical Science, Associate

Professor,

A. P. Savelyev, Doctor of Technical Science, Full

Professor,

O. V. Savina, Doctor of Agricultural Science, Full Professor

I. A. Uspenskiy, Doctor of Technical Science, Full Professor

M. N Chatkin, Doctor of Technical Science, Full Professor, Professor

Computer-Aided Makeup and Design - N.V. Simonova

Proof-Reader - E.L. Malinina

Translation - V.V. Romanov

Editorial address: 390044, Ryazan, Kostycheva str., 1., RM. 103. tel: 8(4912)34-30-27, e-mail: vestnik@rgatu.ru Circulation 700. Order No. 1447. Date of publication Date of publication. 27.03.2020r.
Certificate of registration of mass media PI № FS77-51956, issued by the Federal service for supervision in the field of communications, information technology and mass communications November 29, 2012

Printed in the Publishing house of the RGATU, Ryazan, Kostycheva str., 1., RM. 103. Price edition 185 rubles 50 kopecks Subscription index of the publication in the prospectus of the "Press of Russia" 82422 


\section{Содержание}

СЕЛЬСКОХОЗЯЙСТВЕННЫЕ НАУКИ

БОЧАРОВА П. А., БАЧИНСКАЯ В. М., ПЕТРОВА Ю. В. ПРИМЕНЕНИЕ ИММУНОМОДУЛИРУЮЩЕГО ЛЕКАРСТВЕННОГО ПРЕПАРАТА ГАМАВИТ В КРОЛИКОВОДСТВЕ И ВЛИЯНИЕ ЕГО НА ПОКАЗАТЕЛИ КАЧЕСТВА МЯСА

ВАСИЛЬЧЕНКО Н. И, ЗВЯГИН Г.А. ПЕТРОВА А. А. ВЛИЯНИЕ ПОЛЕЗАЩИТНЫХ ЛЕСОПОЛОС НА ОСНОВНЫЕ ПОКАЗАТЕЛИ ПЛОДОРОДИЯ ЧЕРНОЗЕМОВ ЮЖНЫХ СЕВЕРНОГО КАЗАХСТАНА

ГАБИБОВ М. А. ЭФФЕКТИВНОСТЬ БИОЛОГИЧЕСКИХ И МИНЕРАЛЬНЫХ УДОБРЕНИЙ НА ТЕМНО-СЕРОЙ ЛЕСНОЙ ПОЧВЕ

ГЕРЦЕВА К. А., ДУБОВ Д. В., КАДЫРОВ А. В., КИСЕЛЕВА Е. В., СИТЧИХИНА А. В. ЭФФЕКТИВНОСТЬ КОРМОВОЙ ДОБАВКИ «КАУФИТ ДРАЙ ПЛЮС» ПРИ ПРОФИЛАКТИКЕ ВНУТРЕННИХ НЕЗАРАЗНЫХ БОЛЕЗНЕЙ У КОРОВ В ПОСЛЕРОДОВОЙ ПЕРИОД

ДОКУКИН Ю.В. ВЛИЯНИЕ МИНЕРАЛЬНОГО ПИТАНИЯ НА МЕДОВУЮ ПРОДУКТИВНОСТЬ МОРДОВНИКА ШАРОГОЛОBOГO (ECHINOPS SPHAEROCEPHALUS L.)

ЗУБАРЕВ В. А., МАЖАЙСКИЙ Ю. А. ВЛИЯНИЕ ОСУШЕНИЯ НА ИЗМЕНЕНИЕ АГРОХИМИЧЕСКИХ СВОЙСТВ ЛУГОВОГЛЕЕВЫХ ПОЧВ СРЕДНЕАМУРСКОЙ НИЗМЕННОСТИ

КАРЕЛИНА О.А., ФЕДОСОВА О. А., МУРАШОВА Е. А.,ЗАЙЦЕВ А. М. ВОЗРАСТНЫЕ АСПЕКТЫ ИЗМЕНЕНИЯ РЕПРОДУКТИВНОЙ ФУНКЦИИ ЖЕРЕБЦОВ-ПРОИЗВОДИТЕЛЕЙ

КОЛЕСНИКОВА Т. А., КУЛИКОВА М. А. АГРОМЕЛИОРАТИВНАЯ ОЦЕНКА ПРИМЕНЕНИЯ ПОДГОТОВЛЕННЫХ ЖИДКИХ ОТХОДОВ СВИНОКОМПЛЕКСОВ НА ЧЕРНОЗЕМЕ ОБЫКНОВЕННОМ КРАСНОДАРСКОГО КРАЯ

САВИЧ В. И., БЕЛОПУХОВ С. Л., БАЛАБКО П. Н., СОРОКИН А. Е., ДМИТРЕВСКАЯ И. И. ВЛИЯНИЕ ПРОМОРАЖИВАНИЯ И КРИОГЕНЕЗА НА СВОЙСТВА ПОЧВ

ТУНИКОВ Г. М., СЕРЕБРЯКОВА О. В., ЕСЕНКИНА С. Н. ВОЗДЕЙСТВИЕ ОТРИЦАТЕЛЬНЫХ ТЕМПЕРАТУР И РАЗНЫХ РЕЖИМОВ ХРАНЕНИЯ НА ОСНОВНОЙ ФЕРМЕНТ МЕДА

УЛИВАНОВА Г. В., ГЛОТОВА Г. Н., ФЕДОСОВА О. А., РЫДАНОВА Е. А. АНАЛИЗ ИСПОЛЬЗОВАНИЯ ГЕНОТИПИРОВА НИЯ ПО ПОЛИМОРФНЫМ СИСТЕМАМ ГРУПП КРОВИ И БЕЛКАМ МОЛОКА В ПЛЕМЕННОМ И ПРОМЫШЛЕННОМ СКОТОВОДСТВЕ

\section{ТЕХНИЧЕСКИЕ НАУКИ}

АФАНАСЬЕВ А. М., КОСТЕНКО М. Ю., АФАНАСЬЕВ М. Ю., МАМОНОВ Р. А. ИССЛЕДОВАНИЕ ПРОЧНОСТИ ЯЧЕЕК ПРИ ИЗГИБЕ ПЧЕЛИНОГО СОТА

БЫШОВ Д.Н., КАШИРИН Д. Е., ГОБЕЛЕВ С. Н., БОЧКОВ П. Э., ПАВЛОВ В. В. К ВОПРОСУ ИССЛЕДОВАНИЯ КПД ЭЛЕМЕНТОВ ПЕЛЬТЬЕ

БЫШОВ Н. В., РУЗИМУРОДОВ А. А., ЛИПИН В. Д. ОБОСНОВАНИЕ ПАРАМЕТРОВ ПОПЕРЕЧНОГО ВОРОШИТЕЛЯ ПРУТКОВОГО ЭЛЕВАТОРА КАРТОФЕЛЕУБОРОЧНЫХ МАШИН

КАШИРИН Д. Е., УСПЕНСКИЙ И. А., ПАВЛОВ В. В., ЮХИН И. А., ПЕТУХОВ А. А. К ВОПРОСУ ОБОСНОВАНИЯ РАЦИОНАЛЬНЫХ УСЛОВИЙ ОЧИСТКИ ВОСКОВОГО СЫРЬЯ В ВОДЕ ПРИ ИНТЕНСИВНОМ МЕХАНИЧЕСКОМ ПЕРЕМЕШИВАНИИ

ЛОВЧИКОВ А.П., КОНСТАНТИНОВ М. М., КОРОВИН Ю. И., ОГНЕВ И. И., ОГНЕВ И. Г., ГЛУШКОВ И. Н. ИССЛЕДОВАНИЯ ТОЛЩИНЫ ВАЛКА ХЛЕБНОЙ МАССЫ В ЗАВИСИМОСТИ ОТ УГЛА ПОЛОЖЕНИЯ ПОДБИРАЮЩЕЙ ПОВЕРХНОСТИ ПРУЖИННОГО ПАЛЬЦА

МАКСИМОВ Н.М., НИКИФОРОВ Н. В. ТЕОРЕТИЧЕСКОЕ ОБОСНОВАНИЕ РАБОТЫ ВОСКОПРЕССА «ЛИСИЦА» ПРИ ОТЖИМЕ ВОСКА ИЗ МЕРВЫ

ТЕТЕРИН В. С., ГАПЕЕВА Н. Н., ПАНФЕРОВ Н. С. СПОСОБ АЭРОЗОЛЬНОЙ ОБРАБОТКИ ПРОПАШНЫХ КУЛЬТУР

ФИЛЮШИН О. В., КОСТЕНКО М. Ю., УСПЕНСКИЙ И. А., ЮХИН И. А., УШАНЕВ А. И. АНАЛИЗ ПРОЦЕССА ВЫГРУЗКИ КЛУБНЕЙ ИЗ ТРАНСПОРТНОГО АГРЕГАТА С УСОВЕРШЕНСТВОВАННЫМ САМОСВАЛЬНЫМ КУЗОВОМ ТРИБУНА МОЛОДЫХ УЧЁНЫХ

КАБИЦКАЯ Я.А., КАЛАШНИКОВА Л.А., БОЙКО Е. Г., КАЛАШНИКОВ А. Е. ГЕНЕТИЧЕСКАЯ ИДЕНТИФИКАЦИЯ КАК КРИТЕРИЙ СОВПАДЕНИЙ С ДАННЫМИ ПЕРВИЧНОГО УЧЕТА ЖИВОТНЫХ НА ТЕРРИТОРИИ УФО

РУЧКИНА А. В., УШАКОВ Р. Н., ЕЛИЗАРОВ А. О., АМЕЛИНА Т. Ю. ДИСКРИМИНАНТНЫЙ АНАЛИЗ В ОЦЕНКЕ УРОЖАЙНОСТИ ЗЕРНОВЫХ КУЛЬТУР НА АГРОСЕРЫХ ПОЧВАХ

юБиляры 


\section{Content}

\section{AGRICULTURAL SCIENCE}

BOCHAROVA P. A., BACHINSKAYA V. M., PETROVA Y.V. APPLICATION AN IMMUNOMODULATING DRUG GAMAVIT IN RABBIT BREEDING AND ITS INFLUENCE ON MEAT QUALITY INDICATORS

VASSILCHENKO N. I., ZVYAGIN G.A., PETROVA A. A. THE INFLUENCE OF SHELTER BELTS ON THE BASIC NDICATORS OF FERTILITY OF SOUTHERN CHERNOZEM NORTHERN KAZAKHSTAN

GABIBOV M. A. THE EFFECTIVENESS OF THE BIOLOGICAL AND MINERAL FERTILIZERS

ON DARK-GRAY FOREST SOIL

GERTSEVA K. A., DUBOV D.V., KADYROV A. V.,KISELEVA E. V., SITCHIKHINA A.V. THE EFFECTIVENESS OF FEED ADDITIVES "KOUPIT DRY PLUS" IN THE PREVENTION OF INTERNAL NON-CONTAGIOUS DISEASES OF THE POSTPARTUM PERIOD IN COWS

DOKUKIN Y. V. INFLUENCE OF MINERAL NUTRITION ON HONEY PRODUCTIVITY OF ECHINOPS

SPHAEROCEPHALUS

ZUBAREV V. A., MAZHAYSKY Y. A. THE EFFECTS OF DRAINAGE ON THE CHANGE OF THE AGROCHEMICAL

PROPERTIES OF MEADOW-GLEY SOILS OF THE MIDDLE AMUR LOWLEND

KARELINA O. A., FEDOSOVA O. A., MURASHOVA E.A., ZAITSEV A. M. AGE ASPECTS OF CHANGE OF REPRODUCTIVE FUNCTION TREASURES MANUFACTURERS

KOLESNIKOVA T. A., KULIKOVA M. A. AGROMELIORATIVE EVALUATION OF APPLICATION OF PREPARED LIQUID WASTE OF PIG COMPLEXES ON THE BLACK-SOILS OF THE KRASNODAR REGION

SAVICH V. I., BELOPUKHOV S. L., BALABKO P. N., SOROKIN A. E., DMITREVSKAYA I. I. INFLUENCE OF FROST PENETRATION AND CRYOGENESIS ON SOIL PROPERTIES

TUNIKOV, G. M., SEREBRYAKOVA O. V., ESENKINA S. N. THE IFLUENCE OF NEGATIVE TEMPERATURES AND DIFFERENT STORAGE MODES ON THE MAIN HONEY ENZYME

ULIVANOVA G. V., GLOTOVA G. N., FEDOSOVA O. A, RYDANOVA E. A. ANALYSIS OF THE USE OF GENOTYPING BY POLYMORPHIC SYSTEMS OF BLOOD GROUPS AND MILK PROTEINS IN BREEDING AND INDUSTRIAL CATTLE BREEDING

\section{TECHNICAL SCIENCE}

AFANASYEV A. M., KOSTENKO M. Y., AFANASYEV M. Y., MAMONOV R. A. RESEARCH OF STRENGTH OF CELLS AT BENDING OF BEE CELL

BYSHOV D. N., KASHIRIN D. Y., GOBELEV S.N., BOCHKOV P.E., PAVLOV V. V. RESEARCH EFFICIENCY OF PELTIER ELEMENTS

BYSHOW N. V., RUZIMURODOV A. A., LIPIN V. D. JUSTIFICATION OF THE PARAMETERS OF THE TRANSVERSE TARGITER OF A BAR ELEVATOR OF POTATO HARVESTERS

KASHIRIN D.Y., USPENSKIY I. A., PAVLOV V.V., YUKHIN I. A., PETUKHOV A. A. TO THE QUESTION OF JUSTIFICATION OF RATIONAL CONDITIONS OF WAX RAW MATERIAL PURIFICATION IN WATER WITH INTENSIVE MECHANICAL MIXING

LOVCHIKOV A. P., KONSTANTINOV M. M., KOROVIN Y. I., OGNEV I. I.,OGNEV I. G., GLUSHKOV I. N. EVALUATION OF THICKNESS MEASUREMENT OF A BREAD MASS ROLL DEPENDING ON THE ANGLE OF THE SEARCHING SURFACE OF A SPRING FINGER

MAXIMOV N. M., NIKIFOROV N.V. THEORETICAL JUSTIFICATION OF THE WORK OF THE WAX PRESS "FOX" WHEN PRESSING WAX FROM WASTE

TETERIN V. S., GAPEEVA N. N., PANFYOROV N.S. METHOD FOR AEROSOL SPRAYING OF TILLED CROPS

FILUSHIN O. B., USPENSKY I.A., YUKHIN I. A., USANEW A. I. ANALYSIS OF THE PROCESS OF UNLOADING TUBERS FROM A TRANSPORT UNIT WITH AN IMPROVED DUMP BODY

ITRIBUNE OF YOUNG SCIENTISTS

KABITSKAYA Y. A., KALASHNIKOVA L. A., BOYKO E. G., KALASHNIKOV A. Y. GENETIC IDENTIFICATION AS THE CRITERION OF PRIMARY ERRORS BEHIND DISCRIMINANT ANALYSIS

RUCHKINA A. V., USHAKOV R. N., ELIZAROV A. O., AMELINA T. Y. IN THE ASSESSMENT OF CROP YIELDS ON AGRIBUSINESS SOILS

AHEROES OF THE DAY 


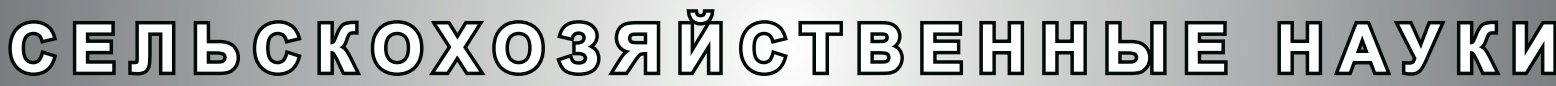

Удк 637.072: 636.5.033

DOI 10.36508/RSATU.2020.45.1.001

\section{ПРИМЕНЕНИЕ ИММУНОМОДУЛИРУЮЩЕГО ЛЕКАРСТВЕННОГО ПРЕПАРАТА ГАМАВИТ В КРОЛИКОВОДСТВЕ И ВЛИЯНИЕ ЕГО НА ПОКАЗАТЕЛИ КАЧЕСТВА МЯСА}

БОчАРОВА Полина Александровна, магистрант 3 курса по направлению подготовки 36.04.01"Ветеринарно-санитарная экспертиза»

БАЧИНСКАЯ Валентина Михайловна, канд. биол. наук, доцент кафредры паразитологии и ветеринарно-санитарной экспертизы, bachinskaya1980@mail.ru

ПЕТРОВА Юлия Валентиновна, канд. биол. наук, доцент кафредры паразитологии и ветеринарно-санитарной экспертизы,

Московская государственная академия ветеринарной медицины и биотехнологии - МВА имени К.И. Скрябина, Москва, Россия

В статье приведен анализ влияния препарата «Гамавит» на показатели качества и безопасности мяса кроликов. Гамавит - комплексный препарат, основными действующими веществами которого являются: нуклеинат натрия - 0,02мг и кислотный гидролизат плаценты денатурированной эмульгированной (ПДЭ) - 0,50мг. Экспериментальные исследования проведены на кафредре паразитологии и ветеринарно-санитарной экспертизы ФГБОУ ВО МГАВМиБ - МВА имени К.И. Скрябина. Объекты исследования - кролики породы Советская шиншилла, подобранные по принципу аналогов с учетом массы, возраста, состояния здоровья и пола, содержащиеся в одинаковых условиях на базе НИЦ эпидемиологии и микробиологии имени Н.Ф. Гамалеи, в минифермах типа кварт. Для эксперимента отобрано 20 кроликов, из которых сорормировали 2 группы. Продолжительность опытов составляла 123 суток (подготовительный - 15 суток и учетный - 108 суток). Кролики первой, опытной группы, в составе основного рациона получали комбинированный иммуномодулирующий лекарственный препарат «Гамавит» в количестве 0,1мг/ке массы тела животного 1 раз в сутки с начала периода откорма в 1-й, 4-й и 9-й дни с интервалом в 21 день перорально. Кроликам второй, контрольной, группы препарат добавлен не был. Продукты убоя (тушка, внутренние органы) оценивались в соответствии с требованиями нормативной документации. Оценка производилась: по органолептическим показателям; была произведена товароведческая оценка туш; установлены физико-химические показатели мяса; токсичность, биологическая ценность мяса, а также качественные показатели мяса. По результатам проведенных органолептических и физико-химических исследований отрицательного влияния препарата Гамавит на качество получаемой продукции кроликов не установлено.

Ключевые слова: безопасность, качество, ветеринарно-санитарная экспертиза, кролики, мясо.

\section{Введение}

На сегодняшний день комплексные иммуномодулирующие препараты получили широкое применение во всех областях животноводства. Данные препараты используются не только в качестве лекарственных и профилактических средств, но и в качестве кормовых добавок.

Отечественными учеными доказана эффективность применения в животноводстве кормовых добавок на основе макро- и микроэлементов, которые положительно влияют на физиологический статус животных и на продуктивность [1-6]. На данный момент предпочтение отдается комплексным препаратам в связи с тем, что данные препараты обладают большей биологической доступностью, что, в свою очередь, позволяет снизить уровень дачи препарата, получая при этом должный результат. За счет высокой биодоступности приме- нение данных комплексов является более эффрективным по сравнению с другими препаратами. Это наблюдается в повышении уровня резистентности организма, сохранности молодняка, стрессоустойчивости, в связи с чем наблюдается повышение продуктивности и процента конверсии корма. А.В. Санин и А.В. Деева (2015) провели исследование действия Гамавита на организм животных с целью фармако-токсикологического обоснования его применения. Авторы утверждают, что при применении данного препарата улучшились показатели воспроизводства, наблюдалось значительное увеличении массы, а также отмечалось снижение заболеваемости незаразными болезнями [7-9].

Данный препарат характеризован как биостимулятор, эффрективный и безопасный при применении его в качестве средства для повышения сохранности, скорости роста, откормочной и мясной

() Бочарова П. А., Бачинская В.М., Петрова Ю.В.,2020 г. 
продуктивности, а также воспроизводительной способности животных.

Цель исследования - изучить влияние препарата Гамавит на показатели качества и безопасности мяса кроликов.

\section{Материалы и методы}

Опыт по изучению биологических свойств препарата Гамавит был произведен на базе НИЦ эпидемиологии и микробиологии имени Н.Ф. Гамалеи, в минифермах типа кварт и на кафедре паразитологии и ветеринарно-санитарной экспертизы ФГБОУ ВО МГАВМиБ-МВА имени К.И. Скрябина. Изучение проводилось на кроликах породы Советская шиншилла, подобранных по принципу аналогов с учетом массы, возраста, состояния здоровья и пола, содержащихся в одинаковых условиях. Для эксперимента было отобрано 20 кроликов, из которых сорормировали 2 группы. Продолжительность опытов составляла 123 дня (подготовительный - 15 дней и учетный- 108 дней). Кроликам второй группы препарат добавлен не был. Кролики первой, опытной группы, в составе основного рациона получали комбинированный иммуномодулирующий лекарственный препарат «Гамавит» в количестве 0,1 мг/кг массы тела животного 1 раз в сутки с начала периода откорма в 1-й, 4-й и 9-й дни с интервалом в 21 день перорально. Ветеринарносанитарные мероприятия в НИЦ эпидемиологии и микробиологии имени Н.Ф. Гамалеи проводились согласно действующим стандартам. Эпизоотологическое состояние было благополучно по инфекционным и инвазионным заболеваниям в течение всего времени проведения опыта. В течение проведения опыта учитывались следующие показатели: сохранность поголовья, поедаемость кормов и их остаток, среднесуточный прирост, валовый прирост, масса кроликов. По окончании опыта был произведен убой кроликов обеих групп для дальнейшего исследования мяса и продуктов убоя по ветеринарно-санитарным показателям. Для гистологического исследования были отобраны сердце, печень, селезенка, а также мышечная ткань. Ветеринарно-санитарная экспертиза мяса кроликов проведена согласно действующим нормативным документам: «Правила ветеринарного осмотра убойных животных и ветеринарно-санитарной экспертизы мяса и мясных продуктов» (1983 г. с дополнениями и изменениями 1988 г.) с учетом требований санитарно-эпидемиологических правил и нормативов «Гигиенические требования к безопасности и пищевой ценности пищевых продуктов» (СанПиН 2.3.2.1078-01). Органолептические исследования мяса кроликов проводили согласно ГОСТ 27747-2016 Мясо кроликов. Мясо кроликов опытной и контрольной групп исследовали на соответствие «Гигиеническим требованиям безопасности и пищевой ценности пищевых продуктов» (СанПиН 2.3.2.1078-01) по показателям содержания первоначальной влаги, протеина, жира и золы. Исследования проводили в соответствии с утвержденными нормативными документами (ГОСТ, МУ, МУК).

\section{Результаты исследований}

За период проведения экспериментальных исследований кролики находились в одинаковых условиях содержания и кормления. Все зоотехнические параметры, предъявляемые к данной породе кроликов, соответствовали требованиям. Результаты исследований представлены в таблице 1.

Таблица 1 - Зоотехнические показатели кроликов на протяжении эксперимента

\begin{tabular}{|l|c|c|}
\hline \multicolumn{1}{|c|}{ Показатели } & Опыт & Контроль \\
\hline Кроликов в эксперименте, голов & 10 & 10 \\
\hline Поступило на убой, голов & 10 & 123 \\
\hline Количество суток содержания & 123 & 100 \\
\hline Сохранность, \% & 100 & $1400 \pm 200$ \\
\hline Масса головы(г): 27.05 & $1400 \pm 200$ & $2114 \pm 236$ \\
\hline 15.06 ( начало опыта) & $2069 \pm 181$ & $2430 \pm 220$ \\
\hline $15.07($ 30-е сутки опыта) & $2560 \pm 140$ & $2870 \pm 220$ \\
\hline 23.08 (70-е сутки опыта) & $3145 \pm 255$ & 100 \\
\hline 30.09 (108-е сутки опыта) & $3690 \pm 140$ & 11960 \\
\hline $\begin{array}{l}\text { Расход корма на 1 кг массы тела } \\
\text { животного, (г) }\end{array}$ & 100 & 261070 \\
\hline Валовой прирост массы за 108 суток & 16210 & \\
\hline Общая поедаемость корма, (г) & 274545 & \\
\hline
\end{tabular}

В результате проведенных исследований нами установлено, что применение препарата Гамавит в дозе 0,1 мл/кг живой массы кроликов способствовало увеличению живой массы на $10 \%$ по отношению к контролю. Валовой прирост в контрольной группе составил 11960,0 г, в опытной 16210,0 г, что на 4250,0 г превышало вес кроликов контрольной группы. По результатам проведенных исследований нами был рассчитан экономиче- ский эффрект применения препарата Гамавит при выращивании кроликов. Экономический эффрект в опытной группе составил 2228,15 рублей, что на 1155,71 рублей больше, чем у контрольной. Из этого следует, что использование препарата Гамавит в схеме выпаивания кроликов является экономически выгодным. На рисунке наглядно показана разница в предубойном и убойном весе исследуемой и контрольной групп. 


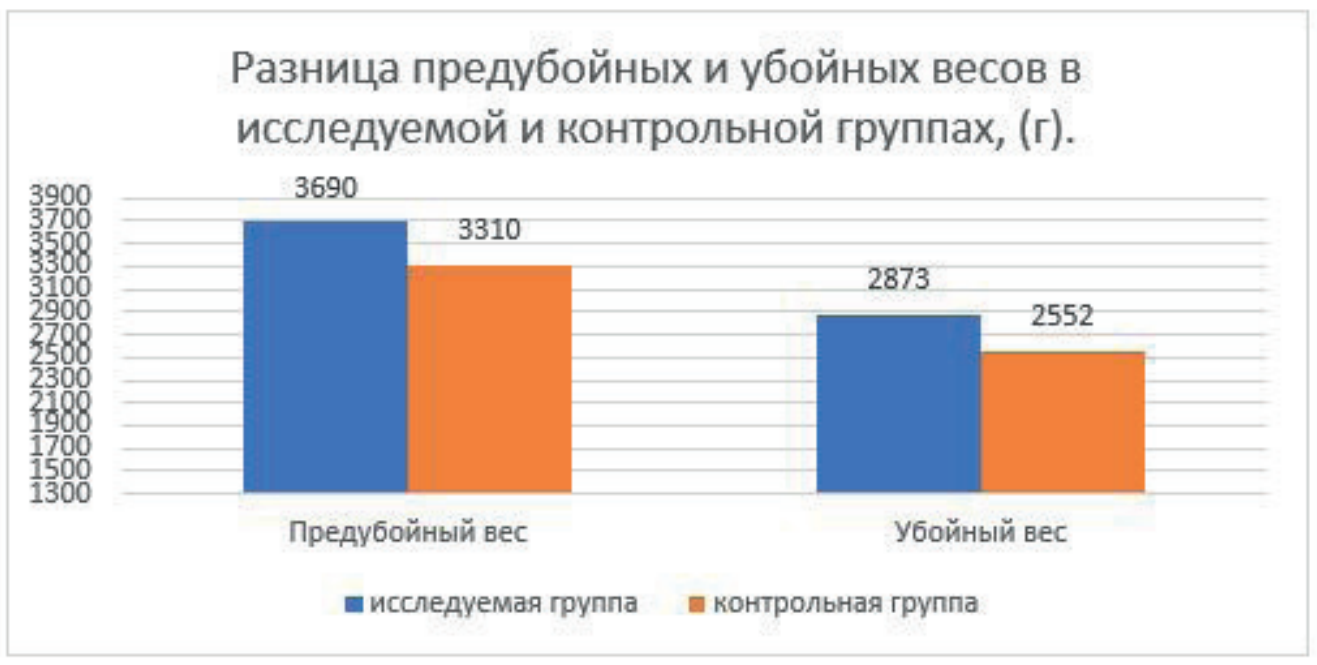

Рис. - Разница предубойного и убойного веса исследуемых кроликов

Одним из этапов ветеринарно-санитарной экспертизы продуктов убоя кроликов обеих групп является органолептическая оценка мяса. В соответствии с нормативно-техническими документами органолептические исследования проводились после процесса созревания мяса, т.е. спустя 24 часа после проведения убоя.

По результату проведенных исследований нами установлено: тушки обеих групп хорошо обескровлены, патологоанатомические изменения, а также побитости и кровоподтеки отсутствуют. Мышечная ткань имеет цвет от бледно-розового до розового. Серозные оболочки чистые, в соответствии с нормой цвета. Подкожный жир имеет цвет от белого до бледно-желтого, что соответствует норме. Запах туши характерный, свойственен свежему мясу кроликов. Мышцы упругие, умеренно влажные, имеют характерный, бледно-розовый цвет. На разрезе - равномерные, бедра округлены. Остистые отростки спинных позвонков не выступают. Бульон прозрачный, ароматный, не имеет посторонних запахов. Паренхима селезенки однородная, умеренно рыхлой консистенции, красно-сиреневатого цвета. Печень имеет коричневый цвет, паренхима соответствует норме. Сердце красновато-бурого цвета, характерной формы. Патологических изменений в органах не обнаружено.

По результатам оценки продуктов убоя кроликов опытной и контрольной групп видимых различий между ними не установлено. Все тушки соответствуют нормативно-правовой документации и являются свежими. По результату ффизико-химических исследований установлено, что тушки кроликов обеих групп являются доброкачественными, $\mathrm{pH}$ опытной группы составил 5,9, контрольной группы - 6,0. Данные показатели соответствуют нормам свежего мяса. Реакция с сульфатом меди дала отрицательный результат.

По результатам микробиологических исследований у животных обеих групп отсутствовали бактерии рода Salmonella и listeria monocytogenes, при этом КМАФАнМ, находилось в пределах нормы и составляло не более $1 \times 10^{4} \mathrm{KOE} / г$, что отвечает требованиям.

По результатам гистологического исследования мышц и внутренних органов мышечная ткань представлена хорошо сформированными мышечными пучками, состоящими из волокон; имеет равномерную толщину, различимые границы и ровный контур. Мышечное волокно равномерно окрашено в розовый цвет, сохранена целостность структуры, не нарушена миофибриллярная структура волокна, поперечная исчерченность сохраняется. Диаметр сосудов не увеличен, в просвете редко наблюдаются эритроциты, эндотелий плоский.

По результатам наших исследований химический состав мяса кроликов полностью отвечает всем требуемым стандартам, заявленным в нормативно-правовой документации. Химический состав мяса зависит от множества факторов, таких как возраст, породные особенности, пол, тип кормления и других. В приведенной ниже таблице представлены данные химического состава мяса кроликов. Анализ был произведен в лаборатории биохимического анализа ФНЦ «ВНИТИП» РАН. Были исследованы шесть проб мяса кроликов по следующим показателям: влага первоначальная, протеин, жир, зола.

Таблица 2 - Химический состав мяса кроликов

\begin{tabular}{|l|c|c|c|c|c|c|c|c|}
\hline \multirow{2}{*}{$\begin{array}{c}\text { Показатель } \\
\%\end{array}$} & \begin{tabular}{c} 
Контроль \\
\cline { 2 - 10 }
\end{tabular} & $\begin{array}{c}\text { Контроль } \\
2\end{array}$ & $\begin{array}{c}\text { Контроль } \\
3\end{array}$ & $\begin{array}{c}\text { Среднее } \\
\text { значение }\end{array}$ & Опыт 1 & Опыт 2 & Опыт 3 & $\begin{array}{c}\text { Среднее } \\
\text { значение }\end{array}$ \\
\hline Влага & 68,86 & 69,58 & 69,17 & 69,20 & 70,42 & 68,52 & 71,79 & 70,24 \\
\hline Протеин & 71,34 & 73,85 & 72,16 & 72,45 & 73,31 & 71,11 & 79,66 & 74,69 \\
\hline Жир & 17,25 & 15,60 & 18,56 & 18,56 & 16,54 & 19,87 & 11,20 & 15,87 \\
\hline Зола & 2,86 & 3,04 & 2,98 & 2,98 & 3,54 & 3,13 & 3,62 & 3,43 \\
\hline
\end{tabular}


Полученные данные позволяют говорить об увеличении первоначальной влаги мяса животных опытной группы на 1,4\% по отношению к этому показателю в контрольной группе. Увеличение процентного содержания протеина - на 3\%, в то время как увеличение процентного содержания золы произошло на 13\% по отношению к пробам в контрольной группе. Эти данные, в свою очередь, позволяют говорить об увеличении качества продукции кролиководства при применении в рационе комплексного иммуномодулирующего препарата Гамавит.

\section{Заключение}

По результатам проведенных органолептических, микробиологических, ффизико-химических, а также гистологических исследований нами не установлено отрицательного влияния препарата Гамавит на доброкачественность продукции кролиководства. Данный препарат может быть рекомендован для применения кролиководческим хозяйствам в дозировке 0,1 мл на кг массы тела животного.

\section{Список литературы}

1.Василевич, Ф.И. Влияние кормовой добавки Абиотоник на ветеринарно-санитарные показатели мяса кроликов / Ф.И. Василевич, В.Н. Шевкопляс, В.М. Бачинская // Проблемы ветеринарии санитарии, гигиены и экологии. - 2019. - №4 (32). - С 375-381.

2.Деникин С.A. Влияние наноразмерного порошка кобальта на эритропоэз у кроликов / C.A. Деникин, Л.Г. Каширина // Вестник Рязанского государственного агротехнологического университета имени П.А. Костычева. - 2013. - №3 (19). - С 106-108.

3.Каширина Л.Г. Взаимосвязь интерьерных показателей кроликов с продуктивностью по вли- янием наноразмерного порошка кобальта / Л.Г. Каширина, С.А. Деникин // Вестник Рязанского государственного агротехнологического университета имени П.А. Костычева. - 2015. - №3 (27). - С 112-117.

4.Каширина Л.Г. Влияние кобальта в наноразмерной форме на санитарно-биологические, физико-химические показатели продуктов убоя и дегустационную оценку мяса овец / Л.Г. Каширина, Е.Н. Качина // Вестник Рязанского государственного агротехнологического университета имени П.А. Костычева. - 2014. - №4 (24). - С 16-21.

5.Каширина Л.Г. Влияние кобальта в наноразмерной форме на физиологические и биохимические процессы в организме кроликов / Л.Г. Каширина, С.А. Деникин // Вестник КрасГАУ. - 2014. - №4 (91) - C 203-207.

6.Коростелева В.П. Влияние цеолитов на качество мяса кроликов / В.П. Коростелева, Э.К. Папуниди, С. Ю. Смоленцев // Мясная индустрия. 2013. - №1. - С. 64-65.

7.Лактионов К. С. Кролиководство в России и за рубежом. Современное состояние и перспективы развития / К.С. Лактионов, О.В. Тимохин // Вестн. Орлов. гос. аграр. ун-та. - 2009. - Т. 17, № 2. - С. 26-27.

8.Фролов А.В. Ветеринарно-санитарная и биологическая оценка качества продуктов животноводства при использовании в рационах кормления добавок «Гумифит» и «Макс Супер Гумат» : дис. ... докт. биолог. наук : 06.02.05 / Фролов Алексей Викторович. - Казань, 2015. - 460 с.

9.Череменина Н.А. Оценка влияния кормовой добавки на состояние организма кролика / Н.А. Череменина, К.А. Сидорова // Изв. Оренбург. гос. аграр. ун-та. - 2010. - Т. 4, №28-1. - С. 87-88.

\section{APPLICATION AN IMMUNOMODULATING DRUG GAMAVIT IN RABBIT BREEDING AND ITS INFLUENCE ON MEAT QUALITY INDICATORS}

Bocharova Polina A., master's student of the 3rd year, in the direction of training 36.04.01 - "Veterinary and sanitary examination" Moscow state Academy of veterinary medicine and biotechnology-MBA named after K. I. Scriabin, Moscow, Russia

Bachinskaya Valentina M., Candidate of Biological Sciences, Associate Professor of the Department of Parasitology and Veterinary-Sanitary Examination, Moscow State Academy of Veterinary Medicine and Biotechnology - MBI named after KI Scriabin, Moscow, Russia, E-mail: bachinskaya1980@mail.ru

Petrova Yuliya V., Candidate of Biological Sciences, Associate Professor of the Department of Parasitology and Veterinary-Sanitary Examination, Moscow State Academy of Veterinary Medicine and Biotechnology MBI named after KI Scriabin, Moscow, Russia, E-mail: belova_u@mail.ru

The article presents an analysis of the effect of the drug "Gamavit" on the quality and safety of rabbit meat. Gamavit is a complex preparation, the main active substances of which are: sodium nucleinate- $0.02 \mathrm{mg}$ and acid hydrolysate of the denatured emulsified placenta (PDE)- $0.50 \mathrm{mg}$. Experimental studies were carried out at the Department of Parasitology and Veterinary and Sanitary examination of the Moscow State Medical Univercity named after K. I. Scriabin. The objects of study are rabbits of the Soviet Chinchilla breed, selected according to the principle of analogues taking into account the weight, age, health and gender, contained in the same conditions on the basis of the SIC Epidemiology and Microbiology named after N. F. Gamalei, in quart types mini-farms. For the experiment, 20 rabbits were selected, of which 2 groups of 10 animals each were formed. The duration of the experiments was 123 days (preparatory - 15 days and accounting-108 days).. Rabbits of the first, experimental group, as part of the main diet received a combined immunomodulating drug "Gamavit" in the amount of $0.1 \mathrm{mg} \backslash \mathrm{kg}$ of animal body weight 1 time per day from the beginning of the fattening period on the 1st, 4th and 9th day with an interval of 21 days orally. For rabbits of the second, control group, the drug was not added. Slaughter products (carcass, internal organs) were evaluated in accordance with 
the requirements of regulatory documentation. Assessment was made: according to organoleptic indicators, a merchandising assessment of carcasses was made, physical and chemical indicators of meat, toxicity, biological value of meat, as well as quality indicators of meat were established. According to the results of organoleptic and physico-chemical studies, the negative effect of the drug Gamavit on the quality of the resulting products of rabbits has not been established.

Key words: safety, quality, veterinary and sanitary examination, rabbits, meat.

\section{Literatura}

1.Vasilevich, F.I. Vliyanie kormovoj dobavki Abiotonik na veterinarno-sanitarnye pokazateli myasa krolikov / F.I. Vasilevich, V.N. SHevkoplyas, V.M. Bachinskaya // Problemy veterinarii sanitarii, gigieny i ekologii. - 2019. - №4 (32). - S 375-381.

2.Denikin S.A. Vliyanie nanorazmernogo poroshka kobal'ta na eritropoez u krolikov / S.A. Denikin, L.G. Kashirina // Vestnik Ryazanskogo gosudarstvennogo agrotekhnologicheskogo universiteta imeni P.A. Kostycheva. - 2013. - №3 (19). - S 106-108.

3.Kashirina L.G. Vzaimosvyaz' inter'ernyh pokazatelej krolikov s produktivnost'yu po vliyaniem nanorazmernogo poroshka kobal'ta / L.G. Kashirina, S.A. Denikin // Vestnik Ryazanskogo gosudarstvennogo agrotekhnologicheskogo universiteta imeni P.A. Kostycheva. - 2015. - №3 (27). - S 112-117.

4.Kashirina L.G. Vliyanie kobal'ta $v$ nanorazmernoj forme na sanitarno-biologicheskie, fiziko-himicheskie pokazateli produktov uboya i degustacionnuyu ocenku myasa ovec / L.G. Kashirina, E.N. Kachina // Vestnik Ryazanskogo gosudarstvennogo agrotekhnologicheskogo universiteta imeni P.A. Kostycheva. - 2014. - №4 (24). - S 16-21.

5.Kashirina L.G. Vliyanie kobal'ta $v$ nanorazmernoj forme na fiziologicheskie $i$ biohimicheskie processy $v$ organizme krolikov / L.G. Kashirina, S.A. Denikin // Vestnik KrasGAU. - 2014. - №4 (91) - S 203-207.

6.Korosteleva V.P. Vliyanie ceolitov na kachestvo myasa krolikov / V.P. Korosteleva, E.K. Papunidi, S. YU. Smolencev // Myasnaya industriya. - 2013. - №1. - S. 64-65.

7.Laktionov K. S. Krolikovodstvo v Rossii i za rubezhom. Sovremennoe sostoyanie i perspektivy razvitiya / K.S. Laktionov, O.V. Timohin // Vestn. Orlov. gos. agrar. un-ta. - 2009. - T. 17, № 2. - S. 26-27.

8.Frolov A.V. Veterinarno-sanitarnaya i biologicheskaya ocenka kachestva produktov zhivotnovodstva pri ispol'zovanii v racionah kormleniya dobavok "Gumifit» $i$ "Maks Super Gumat» : dis. ... dokt. biolog. nauk : 06.02.05 / Frolov Aleksej Viktorovich. - Kazan', 2015. - $460 \mathrm{s.}$

9.CHeremenina N.A. Ocenka vliyaniya kormovoj dobavki na sostoyanie organizma krolika / N.A. CHeremenina, K.A. Sidorova // Izv. Orenburg. gos. agrar. un-ta. - 2010. - T. 4, №28-1. - S. 87-88.

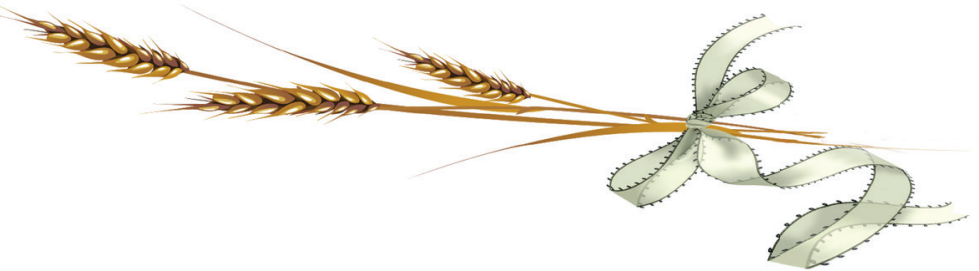

УДК: 631.41

DOI 10.36508/RSATU.2020.45.1.002

\section{ВЛИЯНИЕ ПОЛЕЗАЩИТНЫХ ЛЕСОПОЛОС НА ОСНОВНЫЕ ПОКАЗАТЕЛИ ПЛОДОРОДИЯ ЧЕРНОЗЕМОВ ЮЖНЫХ СЕВЕРНОГО КАЗАХСТАНА}

ВАСИЛЬЧЕНКО Николай Иванович, канд. с.-х. наук, гл. специалист Управления изысканий и мониторинга земель Департамента земельного кадастра, некоммерческое акционерное общество «Государственная корпорация «Правительство для граждан», Республика Казахстан, Vassilchenko-n@ mail.ru

ЗВЯГИн Григорий Александрович, Ph.D, ассистент кафредры «Почвоведение и агрохимия», АО «Казахский агротехнический университет им. С. Сейфуллина», Республика Казахстан, regor1984111@ rambler.ru

ПЕТРОВА Анастасия Алексеевна, магистр почвоведения и агрохимии, главный эксперт- почвовед управления изысканий, мониторинга земель и лабораторных исследований, филиал некоммерческого акционерного общества «Государственная корпорация «Правительство для граждан» по г. Нур-Султан, Республика Казахстан, аsya-petrova1994@mail.ru

Целью данной работы было изучение влияния полезащитных лесополос на свойства черноземов южных в зоне сухой степи. Объектом исследования являлись черноземы южные маломощные Северного Казахстана. Предметом исследований служило изменение фризико-химических свойств данных почв под влиянием полезащитных лесных полос. Исследования свойств черноземов южных проводились под лесополосой и межполосным пространством на территории Урюпинского сельского округа Аккольского района Акмолинской области Республики Казахстан. В результате задержания лесозащитными полосами снега в межполосном пространстве создается значительное количество

(C) Васильченко Н. И., Звягин Г. А., Петрова А.А., 2020 г. 
влаги в почве в период появления всходов зерновых, что является благоприятным фризическим показателем. Наибольшие значения продуктивной влаги соответствуют участкам на расстоянии 5-15 метров от лесополос и составляют 138,00-134,74 мм. Наименьшее количество продуктивной влаги отмечено на расстоянии 140 метров от лесополосы с заветренной стороны и составляет 117,77 мм, что связано с меньшим запасом снежного покрова на данном участке. Исследования показали, что наибольшее содержание гумуса и общего азота в верхнем гумусовом горизонте отмечается под лесополосой и близлежащими участками к лесополосе, что связано с запасом продуктивной влаги и усилением биологических процессов. В средней части межполосного пространства на расстоянии 70-140 метров от лесной полосы плотной конструкции происходит заметное снижение содержания гумуса, которое связано не только с меньшим снегоотложением и запасом продуктивной влаги, но и проявлением в этом промежутке в наибольшей степени выраженности зоны выдувания фракций пыли и ила, что приводит к снижению фрракций ффизической глины в почвах.

Ключевые слова: полезащитные лесополосы, чернозем южный, агрохимические свойства почв, фризико-химические свойства почв, гумус, азот, фосфрор, калий.

\section{Введение}

В условиях степной зоны полезащитные лесные полосы имеют большое агролесомелиоративное значение, они способствуют улучшению и оптимизации водного режима почв, улучшению влагообеспеченности территории землепользования для водоснабжения возделываемых сельскохозяйственных культур. Помимо этого они оказывают многостороннее и существенное воздействие на многие свойства черноземов, улучшая показатели структурного состояния, плотности сложения и гумусового состояния почв. [1-4]. В условиях резко континентального засушливого климата в зоне сухой степи на черноземах южных Северного Казахстана первостепенными задачами остаются накопление и сохранение почвенной влаги, предотвращение процессов деградации почв, что возможно лишь при рациональном землепользовании, в том числе за счет создания полезащитных лесных полос.

Мелиоративная роль лесных полос традиционно связывается с конструкцией насаждений (продуваемая, ажурная, плотная), которая определяет формирование оптимального микроклимата на межполосном поле и приводит к стабильному повышению урожайности сельскохозяйственных культур [5-6]. Для условий Северного Казахстана наилучшим вариантом для снегозадержания считается ажурная конструкция лесополосы [7].

Наибольшие объемы работ по посадке полезащитных лесных полос на территории Северного Казахстана, в том числе в Акмолинской области, были проведены после выхода Постановления Совета Министров СССР от 13 ноября 1975 г. «О мерах по улучшению организации работ по защите почв от ветровой и водной эрозии», в 1976-1980 гг. В этот же период на территории Аккольского района Акмолинской области были заложены лесополосы ажурной конструкции, которые послужили объектом изучения их влияния на свойства черноземов южных.

Исследования ряда ученых свидетельствуют о том, что длительное произрастание защитных насаждений на пахотных землях положительно влияет на агрохимические, фризические и физикохимические свойства почв как непосредственно под лесополосами, так и на межполосных участках [8-10].

В организации агроландшафта на сельскохо- зяйственных землях большую роль играют агролесомелиоративные насаждения, которые снабжают атмосореру кислородом и улучшают биологические процессы, протекающие в почве. Известно, что под влиянием лесополос уменьшается плотность почвы, замедляется процесс снижения содержания гумуса, в сухостепной зоне улучшается водный режим почв лесополос за счет увеличения водопроницаемости и влагоемкости [11].

Лесополосы являются также восстановительным фрактором структурного состояния почв и их плодородия. А.С Бойко отмечал, что содержание гумуса и качество структуры чернозема под пятидесятилетними лесными полосами дуба (при отсутствии травяной растительности) не уступают чернозему многолетней некосимой залежи и существенно превышают варианты с травопольной системой [12]. Причину увеличения гумуса, азота и улучшения структуры А.С. Бойко связывает с водорастворимыми гуминовыми кислотами: «Вымываясь из подстилки в почву, они пропитывают структурные отдельности и, переходя из золя в гель, способствуют прочности агрегатов» [12]. В почвах под лесополосами происходит увеличение общего содержания органического вещества в результате меньшей интенсивности минерализации, что способствует сохранению гидрофильной части гумусовых веществ, которые, по-видимому, и служат структурообразующим элементом почвенных частиц [13].

Целью работы явилось изучение влияния полезащитных лесных полос на агрохимические, фризико-химические и физические свойства черноземов южных Акмолинской области.

В ходе исследований решались задачи по изучению длительного влияния лесополос на свойства черноземов южных, отвечающие за производительную способность почв: содержание гумуса, катионно-обменную способность почв, распределение карбонатов по профилю почв как внутри лесополосы, так и на межполосном пространстве полей.

\section{Объекты и методы}

Исследования проводились на территории Урюпинского сельского округа Аккольского района Акмолинской области Республики Казахстан. Изменение основных показателей плодородия почв изучалось в ряду: лесная полоса - пашня. Всего было выбрано 8 ключевых участков с закладкой 
почвенных выработок и отбором образцов в четырехкратной повторности: первый в лесополосе, остальные на распаханных участках последовательно с заветренной стороны лесополосы на расстоянии 5, 10, 30, 75, 140, 210 и 240 м. Контролем для изучения зависимости урожайности яровой пшеницы от удаленности участка поля от лесополосы в нашем исследовании послужил наиболее удаленный участок на расстоянии 140 м.

В степных районах по данным многих исследователей более эффективными на процессы накопления снега считаются лесополосы ажурной конструкции, которые и были выбраны для наших исследований. Но с учетом длительного времени, прошедшего с момента посадки лесополос и отсутствия мероприятий по уходу за ними, последние заросли молодыми деревьями и конструкция лесополос на исследуемом объекте стала не продуваемой.

Лесополосы состоят преимущественно из вяза мелколистного, клена американского и их поросли.

Возраст лесополосы составляет 35 лет, высота в среднем составляет 10 метров. Лесополосы расположены с севера на юг, расстояние между лесополосами не превышает 255 метров. Почвенный покров под лесополосой и близлежащими разрезами к лесополосе представлен черноземами южными маломощными слабогумусированными среднесуглинистыми, а на удалении от лесополосы характер почвы меняется на легкосуглинистые. Почвенные образцы отбирались ленточной колонкой по генетическим горизонтам до почвообразующей породы на глубину до 100 см. Основные показатели плодородия почв исследовались по апробированным и общепринятым методикам [14].

В почвенных пробах определялось содержание углекислоты карбонатов ацидиметрически, гумус по Тюрину в модификации Симаковой, общий азот по Къельдалю, валовый фосфор по Гинзбургу, подвижные формы азота по Тюрину и Коновой, подвижный фосфрор и калий по Мачигину, $\mathrm{pH}$ водной суспензии - на $\mathrm{pH}$ - метре, обменный натрий на пламенном фоотометре, обменный кальций и магний по Шмуку в модификации Тюрина.

\section{Результаты и обсуждение}

Исследования показали, что лесные полосы благоприятно влияли на снегораспределение, так как большая часть снега оставалась в границах полей между лесополосами. В зимний период во время поземок и метелистых ветров со средней скоростью ветра зимой $5,8 \mathrm{~m} / \mathrm{c}$ основная масса осадков переносится в приземный слой и задерживается деревьями, кустарниками и стерней зерновых злаков. Наибольшая высота снежного покрова была в самой лесополосе - 250 см и близлежащих участках (10-30 м от лесополосы) - от 60 до 80 см. Наименьшая высота снежного покрова отмечалась в средней части исследуемого участка поля между лесополосами, то есть на расстоянии 140 м от лесополосы и составила 35 см. На расстоянии 15 м до следующей лесополосы толщина снежного слоя увеличивается до $80 \mathrm{~cm}$.

Вследствие наибольшего скопления снега в лесополосе и последующего его таяния весной происходит значительное пополнение запасов влаги в почве. В середине лета запасы продуктивной влаги остаются в лесополосе максимальные. Это связано еще и с тем, что из-за оструктуривания почв лесными насаждениями под пологом лесополосы происходит наибольшее поглощение талых и ливневых вод, прекращение или резкое сокращение поверхностного стока и перевод его во внутригрунтовый. Почва под защитными лесонасаждениями способна поглотить не только образующуюся здесь воду, но и поступающую с вышерасположенных участков склона [15-16], что подтверждается запасом продуктивной влаги под пологом лесополосы, которые составляют 141,07 мм (табл. 1).

Таблица 1 - Запасы продуктивной влаги (мм) в слое почвы 0-20 и 0-100 см

\begin{tabular}{|c|c|c|c|c|c|c|c|c|c|}
\hline \multirow{2}{*}{$\begin{array}{c}\text { Глубина, } \\
\text { см }\end{array}$} & \multirow{2}{*}{ Лесополоса } & \multicolumn{8}{|c|}{ Удаленность от лесополосы } \\
\hline & & $5 \mathrm{~m}$ & $10 \mathrm{~m}$ & $30 \mathrm{~m}$ & $75 \mathrm{M}$ & $140 \mathrm{M}$ & $210 \mathrm{M}$ & $240 \mathrm{~m}$ & $\operatorname{HCP}(0,5)$ \\
\hline \multicolumn{10}{|c|}{ Перед посевом } \\
\hline $0-20$ & 33,42 & 22,34 & 18,48 & 16,95 & 17,09 & 14,30 & 17,23 & 17,89 & 0,35 \\
\hline $0-100$ & 220,50 & 180,10 & 174,90 & 160,00 & 155,90 & 149,80 & 153,60 & 162,40 & 1,67 \\
\hline \multicolumn{10}{|c|}{ Фаза колошения } \\
\hline $0-20$ & 26,62 & 17,28 & 15,00 & 14,78 & 13,17 & 11,44 & 13,78 & 14,20 & 0,15 \\
\hline $0-100$ & 141,07 & 139,72 & 138,65 & 128,60 & 121,75 & 117,77 & 126,95 & 134,74 & 2,80 \\
\hline
\end{tabular}

В результате задержания лесозащитными полосами снега в межполосном пространстве создается значительное количество влаги в почве в период появления всходов зерновых, что в свою очередь является благоприятным физическим показателем и может помочь растениям преодолеть водный стресс во время весенне-раннелетних засух, которые часто наблюдаются в степной зоне Акмолинской области.

Характер распределения влаги в почве во многом повторяет характер снегораспределения. Как видно из таблицы, на межполосном пространстве пахотных участков наибольшие значения продуктивной влаги соответствуют расстоянию 5-15 м от лесополос и составляют 138,00-134,74 мм. На расстоянии 30-45 м от лесополос запасы продуктивной влаги снижаются и составляют 128,60126,95 мм. Наименьшее количество продуктивной влаги отмечается на расстоянии 140 м от лесополосы и составляет 117,77 мм, что связано с меньшим накоплением зимних осадков на данном участке. 
Древесные насаждения способствуют созданию более благоприятных условий для протекания годового биологического круговорота элементов питания, которые приводят к изменению почвенного плодородия [17-18].

Вследствие этого под лесными насаждениями происходит увеличение мощности гумусового горизонта на 14 см. Это связано с более интенсивным процессом выщелачивания почв под лесными полосами при увеличении количества гумуса за счет разложения органических веществ из-за большей увлажненности. Наряду с этим в лесополосах и близлежащих пространствах происходит оседание пылеватых частиц из-за происходящей дефляции почв на открытых пространствах поля, что также способствует увеличению мощности верхнего гумусового горизонта. Мощность гумусового горизонта в лесополосе составляет 55 см. В межполосном пространстве обследуемого участка средняя мощность генетического горизонта составляет $41 \mathrm{~cm}$. В пахотном горизонте в самой лесополосе и в близлежащих участках к лесной полосе отмечено более высокое содержание гумуса и общего азота в сравнении с участками, удаленными от лесополосы (табл. 2).

Таблица 2 - Влияние лесополосы на агрохимические свойства черноземов южных пахотного горизонта

\begin{tabular}{|c|c|c|c|c|c|c|}
\hline \multirow{2}{*}{$\begin{array}{c}\text { Расстояние } \\
\text { от лесополосы }\end{array}$} & \multirow{2}{*}{$\begin{array}{c}\text { Гумус, } \\
\%\end{array}$} & \multirow{2}{*}{$\begin{array}{l}\text { Общий } \\
\text { азот, \% }\end{array}$} & \multirow{2}{*}{$\begin{array}{c}\text { Валовый } \\
\text { фоссфор, \% }\end{array}$} & \multicolumn{3}{|c|}{ Подвижные элементы, мг/кг } \\
\hline & & & & азот & фоссфрор & калий \\
\hline Лесополоса & 2,56 & 0,15 & 0,13 & 39,20 & 20,0 & 1000,0 \\
\hline $5 \mathrm{~m}$ & 2,14 & 0,15 & 0,13 & 36,38 & 10,8 & 590,0 \\
\hline $10 \mathrm{~m}$ & 1,96 & 0,14 & 0,12 & 31,52 & 16,5 & 580,0 \\
\hline $30 \mathrm{~m}$ & 1,94 & 0,13 & 0,12 & 29,52 & 11,9 & 400,0 \\
\hline $75 \mathrm{M}$ & 1,93 & 0,12 & 0,12 & 26,82 & 14,0 & 390,0 \\
\hline $140 \mathrm{~m}$ & 1,90 & 0,11 & 0,11 & 26,10 & 8,4 & 350,0 \\
\hline 210м (45м до ближней лесополосы) & 1,96 & 0,13 & 0,12 & 33,88 & 15,5 & 480,0 \\
\hline 240 м (15м до ближней лесополосы) & 1,96 & 0,15 & 0,13 & 33,73 & 10,0 & 590,0 \\
\hline $\mathrm{HCP}_{(0,5)}$ & 0,16 & 0,02 & 0,01 & 2,06 & 2,15 & 63,69 \\
\hline
\end{tabular}

Содержание гумуса в межполосном пространстве обследуемого участка поля меняется в зависимости от снегонакопления и влагозапасов, где имеют место наибольшая биологическая активность и благоприятные условия роста и развития растений, идет накопление большей биомассы растений. На расстоянии 75-140 м от лесной полосы плотной конструкции происходит заметное снижение содержания гумуса, которое связано не только со снижением снегоотложения и запасами продуктивной влаги, но и с наличием в этом промежутке наибольшей выраженности зоны выдувания, приводящей к развитию эрозионных процессов. На участках наиболее удаленных от лесополосы отмечается снижение содержания илистой фракции и физической глины, они относятся по гранулометрическому составу к легкосуглинистым разновидностям; ближе к лесополосе разновидность уже среднесуглинистая. Наименьшее количество валового азота отмечено на расстоянии от полосы 140 м и составляет 0,11\%; соответственно и количество гумуса в пахотном горизонте низкое - не превышает 1,90\%.

На количество валовых форм фоссрора черноземов южных маломощных лесозащитные полосы на территории Акмолинской области не оказывают существенного влияния, как и на валовый азот. В лесополосе количество валового фосфора составляет $0,13 \%$, а в межполосном пространстве варьирует в верхнем гумусовом горизонте в пределах 0,11-0,13\%. Наименьшее количество валового фоосфора отмечено на ключевом участке, расположенном в 140 м от лесополосы.
Сумма обменных оснований в верхнем гумусово-аккумулятивном горизонте черноземов южных маломощных исследуемого участка варьирует в пределах 12,94-14,69 мг-экв/100 г почвы. Она невысокая для данного типа почв, что объясняется низким содержанием гумуса и илистой фрракции в гранулометрическом составе. Среди суммы поглощенных оснований доминирует кальций, на долю которого приходится от 70,84 до 92,39\%. Существенных изменений в пахотном горизонте в распределении поглощенного кальция не отмечается, но все же наименьший процент $(70,84 \%)$ приходится на участок, удаленный от лесополосы на 140 м, который характеризуется более облегченным гранулометрическим составом в связи с дефрляционными процессами и низким содержанием гумуса.

В подзоне южных черноземов Акмолинской области отсутствуют почвы со слабокислой или кислой реакцией среды почвенного раствора, поэтому исследовалось влияние лесополосы на реакцию почвенной среды. Реакция почвенного раствора черноземов в верхнем гумусовом горизонте под лесополосой и в межполосном пространстве нейтральная, книзу усиливается до слабощелочной, а в почвообразующей породе даже до щелочной.

Наибольшее выщелачивание почвенного профиля отмечается под пологом лесополосы и достигает глубины 55 см, о чем свидетельствуют морфологические признаки почвенных выработок лесополосы и аналитические данные по содержанию карбонатов кальция. В межполосном 
пространстве карбонаты кальция отмечаются на глубине 24-40 см. Максимальное количество карбонатов кальция отмечается в горизонте перехода к материнским породам и почвообразующей породе $-17,88 \%$.

Влияние лесных полос на содержание подвижных фрорм фросфора в черноземах южных обычных маломощных слабогумусированных проявляется недостаточно четко. Исследования указывают на небольшое уменьшение содержание подвижного фосфора около лесополосы. Наблюдения показали, что на расстоянии 5 м с заветренной стороны количество подвижного фосфора составило 10,8 мг/кг почвы, а с наветренной стороны на расстоянии 15 м от лесополосы количество подвижного фросфора составило 10,0 мг/кг почвы. На расстоянии 10-30 м с заветренной и на расстоянии 45 м с наветренной стороны от лесных полос складываются наилучшие условия фросфорного режима, там количество подвижного фосффора составляет 16,5-14,0 и 15,5 мг/кг почвы, соответственно. Наименьшее количество подвижного фоссрора отмечено в середине межполосного участка на расстоянии 140 м от лесополосы - 8,40 мг/кг почвы, что свидетельствует о неблагоприятных условиях для получения высоких урожаев сельскохозяйственных культур.

Под пологом лесной полосы количество обменного калия в пахотном горизонте высокое и достигает максимальных величин - до 1000,0 мг/кг почвы, а затем постепенно убывает и в нижележащем горизонте на глубине 33-55 см составляет 720,0 мг/кг почвы. Обеспеченность обменным калием на исследуемом межполосном участке для зерновых культур высокая, но в то же время следует отметить его наибольшее содержание в близлежащих участках к лесополосам
(580,0-590,0 мг/кг почвы). По мере удаления от лесополосы усвояемого калия становится меньше и наименьшее его количество отмечается на расстоянии 140 м от лесополосы (350,0 мг/кг почвы), что связано со снижением гумуса в пахотном горизонте и снижением илистой и коллоидной фракции в гранулометрическом составе. Вниз по профилю количество подвижного калия заметно уменьшается во всех исследуемых почвенных выработках.

Распределение легкогидролизуемого азота в черноземах южных обычных маломощных в межполосном пространстве лесозащитных насаждений находится в той же зависимости, что и содержание гумуса, который служит прямым источником элементов питания. В лесополосе и прилегающих к ней участков содержится наибольшее его количество. Наименьшее количество легкогидролизуемого азота отмечается на расстоянии 140 м от лесополосы и составляет 28,0 мг/кг почвы.

При удалении от лесной полосы происходит ухудшение почвенной структуры верхнего гумусового горизонта от пылевато-комковатой до крупнокомковатой-глыбистой. Вблизи действия лесных полос плотность сложения почв в слое 20-30 см

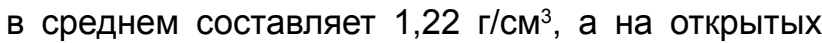
участках поля на удалении до 75-140 м она уже

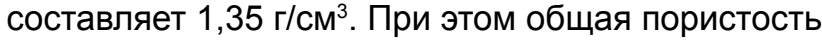
с увеличением плотности сложения почвы также снижается с 65 до $50 \%$.

Воздействие полезащитных лесных полос на агрохимические, физико-химические и физические свойства черноземов южных получило свое отражение и на урожайности яровой пшеницы.

По результатам исследований выявлена зависимость урожайности яровой пшеницы от удаленности участка поля от лесополосы (табл. 3).

Таблица 3 - Влияние лесополосы на урожайность яровой пшеницы, ц/га

\begin{tabular}{|l|c|c|c|c|}
\hline \multicolumn{1}{|c|}{$\begin{array}{c}\text { Расстояние } \\
\text { от лесополосы }\end{array}$} & $\begin{array}{c}\text { Валовой сбор } \\
\text { соломы, ц/га }\end{array}$ & $\begin{array}{c}\text { Урожайность } \\
\text { зерна, цІга }\end{array}$ & $\begin{array}{c}\text { Прибавка урожая } \\
\text { зерна по сравне- } \\
\text { нию с контролем }\end{array}$ & $\begin{array}{c}\text { Прибавка урожая по } \\
\text { сравнению контролем, \% }\end{array}$ \\
\hline Край поля & 12,83 & 10,25 & 4,36 & 74,0 \\
\hline $5 \mathrm{M}$ & 15,33 & 10,37 & 4,48 & 76,1 \\
\hline $10 \mathrm{M}$ & 13,36 & 10,17 & 4,28 & 32,6 \\
\hline $30 \mathrm{M}$ & 8,68 & 8,21 & 2,32 & 31,6 \\
\hline $75 \mathrm{M}$ & 8,54 & 7,75 & 1,86 & 0 \\
\hline $140 \mathrm{210м} \mathrm{(45м} \mathrm{до} \mathrm{ближней}$ & 7,27 & 5,89 & 0 & 15,1 \\
\hline $\begin{array}{l}240 \text { м (15м до ближней } \\
\text { лесополосы) }\end{array}$ & 7,76 & 6,78 & 0,89 & 45,3 \\
\hline НСР (0,5) & 10,26 & 8,56 & 2,67 & \\
\hline
\end{tabular}

В пределах зоны влияния лесополосы урожай пшеницы возрастает с приближением к лесозащитной полосе. Самая высокая урожайность яровой пшеницы отмечена на расстоянии 5-30 м от лесополосы. Из этого следует, что основным фактором повышения урожайности яровой пшеницы оказываются запасы продуктивной влаги в почве на участках, непосредственно примыкающих к лесополосам, так как здесь отмечался наибольший влагозапас. При увеличении расстояния от лесополосы урожайность пшеницы постепенно снижалась прямо пропорционально запасам продуктивной влаги. Наименьшая урожайность отмечена на расстоянии 140 м (5,89 ц/га), это объясняется 
низкими запасами влаги и содержанием элементов питания в пахотном горизонте.

Наблюдения свидетельствуют о том, что урожайность зерновых культур определяется запасами продуктивной влаги в почве, накопленной в основном за осенне-весенний период и сохраненной к моменту посева яровых культур. Осадки весеннего периода с оголенной поверхности почвы полностью испаряются, а влага летних дождей полностью расходуется на испарение и транспирацию.

Подводя итоги, можно сказать уверенно, что улучшение водного режима почв способствовало сохранению органического вещества в пахотном горизонте черноземов южных и, соответственно, повышению урожайности пшеницы на участке, расположенном в 30 м от лесополосы, на 176,1\%. В абсолютных показателях прибавка урожая пшеницы составляет 4,48 ц/га в сравнении с участком, расположенном в 140 м от лесополосы.

\section{Выводы}

1. Наибольшее процентное содержание гумуса отмечается в верхнем гумусово-аккумулятивном горизонте черноземов южных под лесополосами.

2. Под воздействием длительного произрастания лесополосы наблюдается увеличение гумусированности почвы на непосредственно прилегающих к лесополосе участках за счет улучшения водного режима почв и усиления биологических процессов.

3. Под пологом лесополосы отмечено выщелачивание почвенного профиля до глубины 55 см. В межполосном пространстве карбонаты кальция отмечены на глубине 40-43 см.

4. На распаханных участках, прилегающих к лесополосам, улучшаются агрохимические свойства почвы и ее водный режим, которые в значительной степени обуславливают величину урожая яровой пшеницы.

5. Почвы, размещенные непосредственно под защитной лесополосой, характеризуются наиболее оптимальными агрохимическими, фризико-химическими и физическими свойствами в сравнении с почвами межполосных распаханных участков.

\section{Список литературы}

1. Адерихин П.Г. Влияние полезащитных лесных полос на структуру обыкновенных черноземов Каменной степи / П.Г. Адерихин, 3.С. Богатырева // Почвоведение. - 1979. - № 2. - С. 71-81.

2. Ахтырцев Б.П. Почвы и их изменение под влиянием лесных полос / Б.П. Ахтырцев // Каменная степь: Лесоаграрные ландшафты. - Воронеж: Изд-во Воронеж. ун-та, 1992. - С. 94-115.

3. Громовик А.И. Влияние полезащитных лесных полос на основные показатели плодородия почв Каменной степи / А.И. Громовик, В.А. Королев, О.А. Йонко // Вестник ВГУ, серия: химия, биология, фрармация. - 2013. - № 1. С. 105-114.

4. Чегодаева Н.Д., Лысенков Е.В., Каргин В.И., Перов Н.А. Эфффективность агроресурсного потенциала на полях, защищенных лесными полосами / Н.Д. Чегодаев, Е.В. Лысенков, В.И. Каргин,
Н.А. Перов // Достижения науки и техники АПК. 2007. - №9 - С. 47.

5. Агролесомелиорация (издание 5-е, переработанное и дополненное) / Л.И. Абакумова, А.Т. Барабанов, М.Н. Белицкая и др. - Волгоград: ВНИАЛМИ, 2006. - 746 с.

6. Танюкевич В.В. Надземная фритомасса лесных полос, их влияние на ветровой режим и влагонакопление агроландшафтов / В.В. Танюкевич // Научный вестник КубГАУ. - 2013. - № 91. C.1-18

7. Васильев М.Е. Полезащитное разведение в сухой степи Алтайского края и Северного Казахстана: автореф. дисс. доктора с.-х. наук. - Л. 1978. -37 c.

8. Ишутин Я.Н. Лесополосы в Кулундинской степи. - Барнаул. - 2005. - 159 с.

9. Константинов В.Д. Влияние лесных полос на плодородие южного чернозема в Северном Казахстане: автореф. дис. ... канд. биологических наук. - Томск. - 1972. - 22 с.

10. Болотов А.Г., Беховых Ю.В., Сизов Е.Г., Поскотникова О.Н. Физико-химические свойства черноземов под лиственными лесополосами / А.Г. Болотов, Ю.В. Бековых, Е.Г. Сизов, О.Н. Поскотникова // Вестник АГАУ. - 2014. - № 5 (115). - С. 56-62.

11. Михин В.И., Михина Е.А. Лесомелиорация ландшафтов Среднерусской возвышенности / В.И. Михин, Е.А. Михина // Социально-экономические проблемы лесного комплекса. - Екатеринбург: УГЛТУ, 2005. - С. 314-316.

12. Бойко А.С. Воздействие лесных полос в Каменной степи / А.С. Бойко // Вопросы травопольной системы земледелия. - М.: Наука, 1953. - T. 2. - C. 423-427.

13. Хайдапова Д.Д., Милановский Е.Ю, Честнова В.В. Оценка реологическими методами восставновления структуры почв под влиянием выращивания лесополос на антропогенно нарушенных почвах / Д.Д. Хайдапова, Е.Ю. Милановский, В.В. Честнова // Вестник Алтайского государственного аграрного университета. - 2014. - №6 (116). - С. 53-57.

14. Аринушкина Е.В. Руководство по химическому анализу почв. - М.: Изд-во МГУ, 1970. - 487 с.

15. Павловский Е.С. Устройство агролесомелиоративных насаждений. - М.: Лесная промышленность, 1973. - 126 с.

16. Орлов Д.А. Эрозия и эрозионноопасные земли Западной Сибири. - Новосибирск.: Наука, 1983. -208 c.

17. Van Roode Mirjarn. The effects of vegetative barrier strips on surface runoff and soil erosion in Machakos, Kenia. A statisticall versus a spatial modeling approach / R.M. Van // Ned. Geogr. Stud. 2000. - № 278. - P. 1-281.

18. Huang Runguan, Liu Gui Kai, Yuan Chuanwe, Pan Lei, Xia Jianping. Beihua daxue xuebao. Ziran kexue ban / R. Huang, G.K. Liu, C. Yuan, L. Pan, J. Xia // J. Beihua Univ. Natur. Sci. - 2000. - № 4. - P. 342-346. 


\section{THE INFLUENCE OF SHELTER BELTS ON THE BASIC INDICATORS OF FERTILITY OF SOUTHERN CHERNOZEM NORTHERN KAZAKHSTAN}

Vassilchenko Nikolay l., Candidate of agricultural sciences. Non-profit joint-stock company "State Corporation" Government for Citizens " Chief Specialist of the Department of Surveys and Land Monitoring; Republic of Kazakhstan, Vassilchenko-n@mail.ru

Zvyagin Grigoriy A., Ph.D, LLP "S. Seifullin Kazakh Agro Technical University", assistant of the department "Soil Science and Agrochemistry", Republic of Kazakhstan, regor1984111@rambler.ru

Petrova Anastassiya A., Master of soil science and agrochemistry, Subsidiary of Non profit joint stock company "State corporation "Government for Citizens "in the city of Nur-Sultan, Chief Expert of the Management of Surveys, Land Monitoring and Laboratory Research, Republic of Kazakhstan, asya-petrova1994@mail.ru

The aim of this work was to study the influence of shelter belts on the properties of southern chernozems in the area of dry steppe. The object of study was the southern chernozems of low-power of Northern Kazakhstan. The subject of research was the change of physico-chemical properties of these soils under the influence of woodland belts. Studies of the properties of southern chernozems were carried out under the woodland belts and between bands on the territory of Uryupinsk rural district of the Akkolsky district of Akmola region of Kazakhstan Republic. As a result of snow retention by forest protection strips in the inter-lane space, a significant amount of moisture is created in the soil during the emergence of grain seedlings, which is a favorable physical indicator. The highest value of productive moisture correspond sections at a distance of 5-15 meters from the woodland belts and amount of 138.00-134,74 $\mathrm{mm}$. The smallest amount of productive moisture was noted at a distance of 140 meters from the shelterbelt with the leeward side and is $117,77 \mathrm{~mm}$, which is associated with a smaller reserve of snow cover on this area. Studies have shown that the highest content of humus and total nitrogen in the upper of humus horizon is marked under the woodland belts and near by areas to the woodland belts, which is associated with of the productive moisture reserves and the are strengthening of biological processes. In the middle part between woodland belts at a distance of 70-140 metres from the forest zone a dense design there is a noticeable decrease in the humus content, which is associated not only with less snow deposition, but of manifestation of this interval in the highest intensity zone of blowing dust fractions and silt which leads to lower fractions of physical clay in soils.

Key words: shelter belts, southern chernozem, agrochemical soil properties, physicochemical soil properties, humus, nitrogen, phosphorus, potassium.

\section{Literatura}

1. Aderikhin P.G. Vliyanie polezashchitnykh lesnykh polos na strukturu obyknovennykh chernozemov Kamennoy stepi / P.G. Aderikhin, Z.S. Bogatyreva // Pochvovedenie. - 1979. - № 2. - S. 71-81.

2. Akhtyrtsev B.P. Pochvy i ikh izmenenie pod vliyaniem lesnykh polos / B.P. Akhtyrtsev // Kamennaya step: Lesoagrarnye landshafty. - Voronezh: Izd-vo Voronezh. un-ta, 1992. - S. 94-115.

3. Gromovik A.I. Vliyanie polezashchitnykh lesnykh polos na osnovnye pokazateli plodorodiya pochv Kamennoy stepi /A.I. Gromovik, V.A. Korolev, O.A. Yonko // Vestnik VGU, seriya: khimiya, biologiya, farmatsiya. - 2013. - № 1. S. 105-114.

4. Chegodaeva N.D., Lysenkov Ye.V., Kargin V.I., Perov N.A. Effektivnost agroresursnogo potentsiala na polyakh, zashchishchennykh lesnymi polosami / N.D. Chegodaev, Ye.V. Lysenkov, V.I. Kargin, N.A. Perov // Dostizheniya nauki i tekhniki APK. - 2007. - №9 - S. 47.

5. Agrolesomelioratsiya (izdanie 5-e, pererabotannoe i dopolnennoe) / L.I. Abakumova, A.T. Barabanov, M.N. Belitskaya i dr. - Volgograd: VNIALMI, 2006. - 746 s.

6. Tanyukevich V.V. Nadzemnaya fitomassa lesnykh polos, ikh vliyanie na vetrovoy rezhim i vlagonakoplenie agrolandshaftov / V.V. Tanyukevich // Nauchnyy vestnik KubGAU. - 2013. - № 91. - S.1-18.

7. Vasilev M. Ye. Polezashchitnoe razvedenie v sukhoy stepi Altayskogo kraya i Severnogo Kazakhstana: avtoref. diss. doktora s.-kh. nauk. - L. - 1978. - 37 s.

8. Ishutin Ya.N. Lesopolosy v Kulundinskoy stepi. - Barnaul. - 2005. - 159 s.

9. Konstantinov V.D. Vliyanie lesnykh polos na plodorodie yuzhnogo chernozema v Severnom Kazakhstane: avtoref. dis. ... kand. biologicheskikh nauk. - Tomsk. - 1972. - 22 s.

10. Bolotov A.G., Bekhovykh Yu.V., Sizov Ye.G., Poskotnikova O.N. Fiziko-khimicheskie svoystva chernozemov pod listvennymi lesopolosami / A. G. Bolotov, Yu.V. Bekovykh, Ye.G. Sizov, O.N. Poskotnikova // Vestnik AGAU. - 2014. - № 5 (115). - S. 56-62.

11. Mikhin V.I., Mikhina Ye.A. Lesomelioratsiya landshaftov Srednerusskoy vozvyshennosti / V.I. Mikhin, Ye.A. Mikhina // Sotsialno-ekonomicheskie problemy lesnogo kompleksa. - Yekaterinburg: UGLTU, 2005. - S. 314-316.

12. Boyko A.S. Vozdeystvie lesnykh polos v Kamennoy stepi / A.S. Boyko // Voprosy travopolnoy sistemy zemledeliya. - M.: Nauka, 1953. - T. 2. - S. 423-427.

13. Khaydapova D.D., Milanovskiy Ye.Yu, Chestnova V.V. Otsenka reologicheskimi metodami vosstavnovleniya struktury pochv pod vliyaniem vyrashchivaniya lesopolos na antropogenno narushennykh pochvakh / D.D. Khaydapova, Ye.Yu. Milanovskiy, V.V. Chestnova // Vestnik Altayskogo gosudarstvennogo 
agrarnogo universiteta. - 2014. - №6 (116). - S. 53-57.

14. Arinushkina Ye.V. Rukovodstvo po khimicheskomu analizu pochv. - M.: Izd-vo MGU, 1970. - 487 s.

15. Pavlovskiy Ye.S. Ustroystvo agrolesomeliorativnykh nasazhdeniy. - M.: Lesnaya promyshlennost, 1973. $-126 \mathrm{~s}$.

16. Orlov D.A. Eroziya i erozionnoopasnye zemli Zapadnoy Sibiri. - Novosibirsk.: Nauka, 1983. - 208 s.

17. Van Roode Mirjarn. The effects of vegetative barrier strips on surface runoff and soil erosion in Machakos, Kenia. A statisticall versus a spatial modeling approach / R.M. Van // Ned. Geogr. Stud. - 2000. № 278. - P. 1-281.

18. Huang Runguan, Liu Gui Kai, Yuan Chuanwe, Pan Lei, Xia Jianping. Beihua daxue xuebao. Ziran kexue ban / R. Huang, G.K. Liu, C. Yuan, L. Pan, J. Xia // J. Beihua Univ. Natur. Sci. - 2000. - № 4. - P. 342-346.

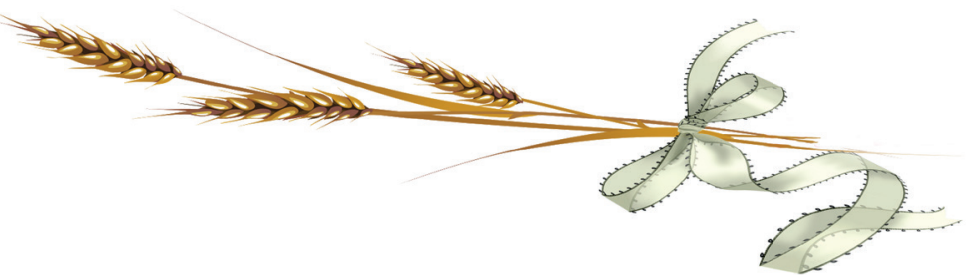

УдК $631.8: 633.14$

DOI 10.36508/RSATU.2020.45.1.003

\section{ЭФФЕКТИВНОСТЬ БИОЛОГИЧЕСКИХ И МИНЕРАЛЬНЫХ УДОБРЕНИЙ НА ТЕМНО-СЕРОЙ ЛЕСНОЙ ПОЧВЕ}

ГАБИБОВ Магомедрасул Абдурашидович, д-р с.-х. наук, професссор ФГБОУ ВО «Рязанский государственный университет имени С.A. Есенина», г. Рязань, m.gabibov@365.rsu.edu.ru

В данной статье рассматриваются вопросы влияния биологических и минеральных удобрений на продуктивность озимой ржи на темно-серой лесной почве в условиях Рязанской области. Исследования проводились по методу расщепленных делянок: на делянках первого порядка на озимой ржи изучали эфрфрективность минеральных и органических удобрений, а на делянках второго порядка - действие биопрепаратов. Результаты исследований показали, что наилучшим из исследованных агроэкологических приемов повышения урожайности озимой ржи является использование в качестве органического удобрения соломы люпина и инокуляции семян биопрепаратами ризоагрин или фрлавобактерин. Урожайность зерна озимой ржи составляет от 37,5 и/га при использовании ризоагрина и до 38,7 и/га - фрлавобактерина, в среднем за 3 года. Относительно фоона прибавка составляет 6,7 и 7,9 и/га или 21,9 и 25,5\%. При данном агротехнологическом приеме прибавка получена как за счет увеличения продуктивных стеблей с $495 \mathrm{~m} / \mathrm{M}^{2}$ до $521 \mathrm{um} / \mathrm{M}^{2}$ при обработке ризоагрином и $538 \mathrm{um} / \mathrm{M}^{2}$ при обработке фрлавобактерином, так и за счет увеличения массы зерна в колосе (35,1 г на контроле, 37,5 г при обработке ризоагрином и 37,7 г фрлавобактерином). Необходимо отметить, что этот максимальный уровень урожайности в опыте был достигнут без внесения минеральных азотных удобрений. В целом наблюдается прямая корреляция между содержанием азота и урожайностью озимой ржи. Вынос основных элементов питания возрастает с увеличением урожайности.

Ключевые слова: минеральные удобрения, солома, биопрепараты, ризоагрин, фрлавобактерин, озимая рожь, урожайность, структура, продуктивные стебли.

\section{Введение}

В мировом сообществе сельскохозяйственные культуры служат основным продовольственным сырьем, так как являются продуктами первой необходимости. Основным же звеном в цепи сельскохозяйственных культур являются зерновые, от которых зависит продовольственная безопасность всех развитых стран мира. Зерновые культуры регулируют цены на всю сельскохозяйственную продукцию, и сырьевой рынок сельхозпроизводителя отталкивается от количественных показателей на такие культуры как пшеница, ячмень, рожь и другие.

На земном шаре под сельскохозяйственные культуры занята почти половина площади пашни, так как они являются основной пищей человече- ства. Зерновое хозяйство является основой всего сельскохозяйственного производства. От роста производства зерна зависит удовлетворение растущих потребностей населения в хлебобулочных изделиях, потребность в кормах для животноводства и увеличение производства отдельных видов технического сырья для промышленности.

В истории российского земледелия зерновые культуры также всегда играли немаловажную роль, как ценные хлебные и кормовые культуры. В 1990-е годы, в связи с переменой общественно-экономической формации в Российской Федерации, произошел спад производства зерновой продукции. В начале 2000-х годов с переменой в руководстве страны начался подъем сельскохозяйственного производства. На современном

() Габибов М. А., 2020 г. 
этапе, в связи со сложившимися экономическими условиями, Россия вышла снова на передовые позиции по производству зерновой продукции и ее экспорту, как и до Первой Мировой войны.

Одним из наиболее доступных в настоящее время биологических средств повышения урожайности сельскохозяйственных культур и поддержания почвенного плодородия является использование соломы зерновых культур и биологических препаратов в качестве удобрений. В связи с этим становятся актуальными исследования по изучению различных видов соломы на фоне бактериальных удобрений и их сопоставление с минеральными удобрениями [2, 3, 4, 9].

\section{Объекты и методы}

Рязанская область в почвенном отношении сочетает в себе черты переходной полосы - между лесной почвенной зоной и степной. Данное переходное положение обуславливает образование на ее территории определенного почвенного покрова [1]. Поэтому климат Рязанской области умеренно континентальный, характеризуется теплым летом, умеренно-холодной зимой с устойчивым снежным покровом и хорошо выраженными, но менее длительными переходными сезонами года - весной и осенью.

Исследования проводились на опытном участке Рязанского государственного университета имени С.А. Есенина (РГУ). После двухлетних исследований опыты закладывали в опытно-производственном хозяйстве для подтверждения результатов исследований и на третий год снова на стационарном участке. В работе приведены данные за 3 года исследований - на опытном участке университета.

Почва опытного участка РГУ темно-серая лесная тяжелосуглинистая с преимуществом фракции крупной пыли. Гумусовый горизонт достигает 30 см, темной окраски, комковато-ореховатой, комковато-пылеватой структуры, с содержанием гумуса $3,1 \%$ в пахотном слое и слабокислой реакцией $\left(\mathrm{pH}_{\mathrm{kcl}} 5,7\right)$. Степень насыщенности основаниями верхней части профиля составляет $70 \%$, а емкость поглощения 26 мг·экв. В гумусе наблюдается некоторое преобладание гуминовых кислот над фульвокислотами. Содержание фоссрора составляет 9,4 мг на 100 г почвы, калия - 11,2 мг/100 г почвы. По обеспеченности подвижными формами это средний класс почвы.

Опыт был развернут во времени и в пространстве на трех полях. Исследования проводились по методу расщепленных делянок: на делянках первого порядка на озимой ржи изучали эффрективность минеральных и органических удобрений, а на делянках второго порядка - действие биопрепаратов. На озимой ржи испытывали действие ризоагрина и флавобактерина.

Схема опыта на озимой ржи включала восемь вариантов:

1) фон $\left(P_{60} K_{60}\right)$;
2) $\mathrm{\phi oH}+\mathrm{N}_{30}$;

3) фоон $+\mathrm{N}_{60}^{30}$;

4) фон + ризоагрин/фрлавобактерин (p/ф);

5) фон $+\mathrm{N}_{30}+$ ризоагрин/фрлавобактерин;

6) фонн + солома ячменя $+\mathrm{N}_{30}+$ ризоагрин/ фрлавобактерин;

7) фрон + солома гречихи + $\mathrm{N}_{30}+$ ризоагрин/фрлавобактерин;

8) фон + солома люпина + ризоагрин/флавобактерин.

Обработку семян биопрепаратами проводили в день посева. Гектарную норму биопрепарата разводили в трех литрах воды и перемешивали с гектарной нормой семян. Обработку семян производили вручную. Все это необходимо, чтобы внедрить в ризосферу культуры микроорганизмы, которые содержатся в данных биопрепаратах $[8,12]$.

\section{Экспериментальная часть}

Результаты проведенных исследований на темно-серой лесной почве в условиях Рязанской области показывают, что использование фосфорнокалийных удобрений в дозе по 60 кг/га д. в. дает урожай зерна озимой ржи в пределах от 29,6 до 32,6 ц/га в зависимости от погодных условий года. Это количество минерального фоссфора и калия взято за фон, с которым сравнивается воздействие на озимую рожь исследуемых агроэкологических приемов. Такая же закономерность на серой лесной почве отмечена на озимой пшенице, ячмене и овсе $[6,7,11]$.

При внесении дополнительно к $\mathrm{P}_{60} \mathrm{~K}_{60}$ азотного минерального удобрения в дозе 30 кг/га д. в. урожайность, в среднем за 3 года, возрастает на 2,7 ц/га. Это стандартная реакция растений озимой ржи на внесение азотного удобрения, которая была весьма ожидаемой. Повышение урожайности зерна озимой ржи происходит за счет увеличения числа зерен и массы зерна в колосе (табл. 1). Так, при внесении $\mathrm{N}_{30}$ дополнительно к фросфорнокалийным удобрениям зерен в колосе содержится 20,1 шт., а на фосфорно-калийном фоне 19,9 шт. Также увеличивается масса зерна в колосе с 0,70 грамм до 0,73 грамм, что существенно отражается на урожайности зерна.

Внесение к фону азотного удобрения в дозе 60 кг д.в. на гектар дает достоверную прибавку урожайности, в среднем за 3 года, на 5,2 ц/га или $16,9 \%$. Зависимость прибавки урожая от дозы азота во все три года практически линейная: при увеличении дозы в 2 раза прибавка также возрастает примерно в 2 раза. Заметный вклад в повышение урожайности, кроме числа зерен и массы зерна в колосе, на этом варианте также вносит увеличение числа продуктивных стеблей. Согласно данным структуры урожая число продуктивных стеблей при внесении $\mathrm{N}_{60}$ дополнительно к фону составля-

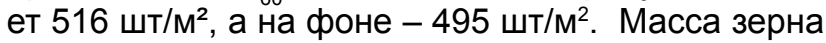
в колосе, соответственно, составляет 0,77 г и на фоне - 0,70 г (табл. 1). 
Таблица 1 - Продуктивность и структура урожая озимой ржи

\begin{tabular}{|c|c|c|c|c|c|c|c|c|}
\hline \multicolumn{2}{|c|}{ Вариант } & $\begin{array}{c}\text { Уро- } \\
\text { жай- } \\
\text { ность } \\
\text { ц/га }\end{array}$ & $\begin{array}{l}\text { Высота } \\
\text { расте- } \\
\text { ний, см }\end{array}$ & $\begin{array}{l}\text { Длина } \\
\text { коло- } \\
\text { са, см }\end{array}$ & $\begin{array}{l}\text { Число } \\
\text { продук- } \\
\text { тивных } \\
\text { стеблей, } \\
\text { шт/м² } \\
\end{array}$ & $\begin{array}{l}\text { Число } \\
\text { зерен } \\
\text { в ко- } \\
\text { лосе, } \\
\text { шт. } \\
\end{array}$ & $\begin{array}{l}\text { Масса } \\
\text { зерна в } \\
\text { колосе, г }\end{array}$ & $\begin{array}{l}\text { Macca } \\
1000 \\
\text { зерен, г }\end{array}$ \\
\hline \multicolumn{2}{|l|}{ 1.ФОН $\left(\mathrm{P}_{60} \mathrm{~K}_{60}\right)$} & 30,8 & 102 & 7,6 & 495 & 19,9 & 0,70 & 35,1 \\
\hline \multicolumn{2}{|l|}{$2 . \Phi \mathrm{OH}^{+} \mathrm{N}_{30}$} & 33,5 & 106 & 8,0 & 499 & 20,1 & 0,73 & 36,3 \\
\hline \multicolumn{2}{|l|}{ 3. $\Phi \mathrm{OH}+\mathrm{N}_{60}$} & 36,0 & 110 & 8,3 & 516 & 20,6 & 0,77 & 37,2 \\
\hline \multirow{2}{*}{ 4. Фон+ } & ризоагрин & 33,5 & 107 & 8,1 & 515 & 20,0 & 0,72 & 36,0 \\
\hline & фллавобактерин & 33,2 & 106 & 8,0 & 511 & 20,1 & 0,73 & 36,3 \\
\hline \multirow{2}{*}{$5 . \Phi \mathrm{OH}+\mathrm{N}_{30}+$} & ризоагрин & 36,1 & 112 & 8,4 & 524 & 21,9 & 0,82 & 37,5 \\
\hline & фллавобактерин & 35,4 & 112 & 8,2 & 536 & 20,8 & 0,77 & 36,9 \\
\hline \multirow{2}{*}{$\begin{array}{l}\text { 6.Фон+солома } \\
\text { ячменя }+\mathrm{N}_{30}+\end{array}$} & ризоагрин & 34,5 & 108 & 8,4 & 498 & 20,9 & 0,76 & 36,5 \\
\hline & фрлавобактерин & 34,4 & 109 & 8,4 & 506 & 20,6 & 0,75 & 36,6 \\
\hline \multirow{2}{*}{$\begin{array}{l}\text { 7.Фон+солома } \\
\text { гречихи }+\mathrm{N}_{30}+\end{array}$} & ризоагрин & 34,2 & 109 & 8,3 & 503 & 20,1 & 0,73 & 36,4 \\
\hline & фрлавобактерин & 34,3 & 108 & 8,4 & 508 & 20,0 & 0,73 & 36,3 \\
\hline \multirow{2}{*}{$\begin{array}{l}\text { 8.Фон+солома } \\
\text { люпина+ }\end{array}$} & ризоагрин & 37,5 & 114 & 8,8 & 521 & 21,7 & 0,81 & 37,5 \\
\hline & фллавобактерин & 38,7 & 118 & 9,0 & 538 & 23,0 & 0,87 & 37,7 \\
\hline
\end{tabular}

Инокуляция семян озимой ржи биопрепаратами ризоагрин и фрлавобактерин, в среднем за 3 года, дает прибавку урожая 2,7 и 2,4 ц/га по сравнению с контролем.

Таким образом, эфрфект от применения данных биопрепаратов практически равен эффекту от внесения 30 кг/га азотных удобрений при гораздо более низкой стоимости первого.

Прибавка от действий биопрепаратов не всегда оказывалась существенной. При недостаточном количестве осадков в вегетационный период $\mathrm{HCP}_{05}$ оказывался несущественным. Это связано с тем, что во время френологической фразы кущения растения озимой ржи недостаточно полно кустятся, а формирование меньшего количества продуктивных стеблей в дальнейшем не компенсируется. В конечном результате это отражается на урожайности основной и побочной продукции. Разница между препаратами незначительно колеблется от года к году, что показывает идентичность действий данных микроорганизмов в условиях Рязанской области.

Еще большую прибавку урожайности дает совместное внесение 30 кг/га минерального азота и биопрепаратов. Так, в частности, от действий ризоагрина отмечено увеличение на 5,3 ц/га (в среднем за 3 года), а фрлавобактерина - на 4,6 ц/га. Урожайность на этих вариантах возросла прежде всего вследствие увеличения числа продуктивных стеблей на $1 \mathrm{~m}^{2}$ и массы зерна в колосе. Повышение урожайности на этих вариантах по сравнению с применением одних только биопрепаратов может быть объяснено тем, что «стартовые» дозы азотных удобрений стимулируют процессы ассоциативной азотфиксации в почве. Результат по уровню примерно соответствует внесению 60 кг/га азотных удобрений, но почти вдвое дешевле последнего.
Совместное применение сразу трех агроэкологических приемов: инокуляции семян биопрепаратами ризоагрин и фрлавобактерин, внесения минерального азота в дозе 30 кг/га и запашки соломы ячменя дает увеличение продуктивности озимой ржи по сравнению с фоном: от инокуляции семян ризоагрином - на 3,7 ц/га и от фрлавобактерина на 3,6 ц/га, в среднем за 3 года. Однако урожайность этих вариантов несколько ниже, чем при использовании биопрепаратов в сочетании лишь с минеральными удобрениями. На наш взгляд, это обусловлено тремя фракторами. Во-первых, солома ячменя довольно бедна азотом, а микроорганизмы, участвующие в ее разложении, потребляют значительное количество этого элемента, снижая поступление его в растения. Во-вторых, солома не перегнивает полностью за период вегетации ржи. И, в-третьих, она улучшает аэробные условия в почве, что отрицательно сказывается на активности нитрогеназы в клетках диазотрофов.

При использовании в качестве биологического удобрения соломы гречихи совместно с биопрепаратами и минеральным азотом на фоне фоссрорно-калийных удобрений эффрект практически такой же, как и при использовании соломы ячменя.

Наибольшую в опыте урожайность обеспечивает совместное применение биопрепаратов с запашкой соломы люпина. Урожайность зерна озимой ржи составляет от 37,5 ц/га при использовании ризоагрина до 38,7 ц/га при использовании фрлавобактерина, в среднем за 3 года. Относительно фона прибавка составляет 6,7 и 7,9 ц/га или 21,9 и $25,5 \%$. При данном агротехнологическом приеме прибавка получена как за счет увеличения продуктивных стеблей, так и за счет увеличения массы зерна в колосе.

Увеличение урожайности объясняется тем, что солома люпина, как бобового растения, сама бо- 
гата азотистыми веществами и эти вещества находятся в более доступной растениям форме. Немаловажную роль играет и то, что солома люпина имеет более мягкую консистенцию, чем солома гречихи и ячменя, что не создает в почве аэробных условий, подобных таковым при запашке соломы этих растений, и не возникает препятствия работе ферментативных комплексов в клетках бактерий-азотфиксаторов. При самой высокой в рамках опыта прибавке урожая на его получение не было затрачено дорогостоящих азотных удобрений, поэтому данный вариант можно считать наиболее экономически выгодным.

Немаловажную роль в изучении продуктивности различных культур играет учет выноса питательных элементов. Вынос питательных веществ из почвы отражает потребность в них растений, так как это связано с биологическими особенностями сельскохозяйственных культур. Поэтому определение выноса питательных веществ растениями имеет большое практическое значение при разработке систем удобрений $[5,10]$.

Из одной и той же почвы разные растения потребляют не только неодинаковое количество питательных элементов, но и в различном соотношении. Помимо видовых и сортовых особенностей растений, в поглощении питательных веществ имеют большое значение почвенно-климатические условия. Данные о потребности культур в питательных веществах выражают их выносом с общим урожаем или на единицу урожая основной продукции с учетом соответствующего количества его побочной части (соломы). Накопление элементов минерального питания в растении достигает максимума в фазе созревания. Это соответствует понятию «потребность растений в питательных веществах».

При разработке новых агротехнологических и энергосберегающих приемов необходимо учитывать хозяйственный вынос, который представляет собой ту часть питательных веществ, которая содержится в товарной продукции, увозимой с поля при уборке (зерно, солома, зеленая масса) [5].

В таблице 2 представлены данные по содержанию основных питательных элементов в продукции озимой ржи при различных агроэкологических приемах возделывания, которые являются основой для расчета выноса этих элементов.

Анализируя данные таблицы 2, можно отметить колебания содержания основных питательных элементов по различным агроэкологическим приемам, причем наиболее заметны различия для общего азота. Его доля в сухом веществе при внесении минеральных азотных удобрений возрастает на 0,07-0,1\% (для зерна), а при использовании биопрепаратов увеличивается более значительно - на 0,21-0,35\% по сравнению с фоном. Содержание азота имеет максимальное значение при сочетании биопрепаратов и соломы люпина (2,37$2,39 \%)$

Таблица 2 - Влияние агроэкологических приемов на содержание основных элементов питания в озимой ржи (среднее за 3 года, \% от массы сухого вещества)

\begin{tabular}{|c|c|c|c|c|c|c|c|}
\hline \multirow{2}{*}{\multicolumn{2}{|c|}{ Схема опыта }} & \multicolumn{3}{|c|}{ Зерно, \% } & \multicolumn{3}{|c|}{ Солома, \% } \\
\hline & & $\mathrm{N}$ & $\mathrm{P}_{2} \mathrm{O}_{5}$ & $\mathrm{~K}_{2} \mathrm{O}$ & $\mathrm{N}$ & $\mathrm{P}_{2} \mathrm{O}_{5}$ & $\mathrm{~K}_{2} \mathrm{O}$ \\
\hline \multicolumn{2}{|l|}{ 1.Фон $\left(\mathrm{P}_{60} \mathrm{~K}_{60}\right)$} & 2,04 & 0,71 & 0,48 & 0,44 & 0,21 & 0,88 \\
\hline \multicolumn{2}{|l|}{ 2. ФоH $+\mathrm{N}_{30}$} & 2,11 & 0,71 & 0,50 & 0,48 & 0,21 & 0,88 \\
\hline \multicolumn{2}{|l|}{ 3.ФОH $+\mathrm{N}_{60}$} & 2,14 & 0,70 & 0,50 & 0,49 & 0,22 & 0,90 \\
\hline \multirow{2}{*}{ 4. Фон + } & ризоагрин & 2,30 & 0,72 & 0,51 & 0,51 & 0,23 & 0,90 \\
\hline & фрлавобактерин & 2,29 & 0,70 & 0,51 & 0,51 & 0,22 & 0,91 \\
\hline \multirow{2}{*}{$5 . \Phi \mathrm{OH}+\mathrm{N}_{30}+$} & ризоагрин & 2,35 & 0,69 & 0,52 & 0,55 & 0,24 & 0,96 \\
\hline & фрлавобактерин & 2,34 & 0,70 & 0,52 & 0,54 & 0,23 & 0,94 \\
\hline \multirow{2}{*}{$\begin{array}{l}6 . \text { Фон + солома } \\
\text { ячменя + } \mathrm{N}_{30}+\end{array}$} & ризоагрин & 2,28 & 0,71 & 0,54 & 0,49 & 0,26 & 0,97 \\
\hline & фрлавобактерин & 2,29 & 0,71 & 0,54 & 0,47 & 0,24 & 0,98 \\
\hline \multirow{2}{*}{$\begin{array}{l}\text { 7.Фон + солома } \\
\text { гречихи + } \mathrm{N}_{30}+\end{array}$} & ризоагрин & 2,26 & 0,72 & 0,54 & 0,49 & 0,27 & 0,98 \\
\hline & фрлавобактерин & 2,25 & 0,72 & 0,53 & 0,48 & 0,28 & 0,98 \\
\hline \multirow{2}{*}{$\begin{array}{l}\text { 8.Фон + солома } \\
\text { люпина + }\end{array}$} & ризоагрин & 2,37 & 0,74 & 0,55 & 0,55 & 0,29 & 0,98 \\
\hline & фрлавобактерин & 2,39 & 0,73 & 0,55 & 0,57 & 0,30 & 0,97 \\
\hline
\end{tabular}

В целом наблюдается прямая корреляция между содержанием азота и урожайностью озимой ржи. Однако при этом на уровень накопления азота применение биопрепаратов по сравнению с минеральными удобрениями оказывает ещё большее влияние, чем на урожайность. Так, вариант внесения $\mathrm{N}_{60}$ по урожайности хотя и превышает варианты с применением биопрепаратов и биопрепаратов в сочетании с соломой ячменя и гречихи, но по содержанию азота уступает им.

Содержание фосфора и калия подчиняется той же закономерности, но их количество возрастает лишь на сотые доли процента и не может рассматриваться как существенное.

Вынос основных элементов питания возрастает с увеличением урожайности. Наиболее существенно увеличение для азота, причем вынос его заметно возрастает не только в расчете на единицу площади, но и на единицу товарной продукции в связи с повышением процентного содержания. При этом, как и для показателя массовой доли азота в сухом веществе, увеличение выноса не яв- 
ляется непосредственной функцией урожайности вследствие большего накопления азота при использовании биопрепаратов. Вынос в вариантах с одними биопрепаратами находится примерно на уровне вариантов их сочетания с $\mathrm{N}_{30}$ и вариантов с внесением $\mathrm{N}_{60}$, обеспечивающих большую урожайность (а на единицу продукции превышает их).

Вынос фоосфора и калия также увеличивается в расчете на единицу площади к наиболее урожайным вариантам. А в расчете на единицу продукции содержание этих элементов возрастает несущественно.

\section{Выводы}

На основании проведенных исследований наилучшим из агроэкологических приемов повышения урожайности озимой ржи является использование в качестве органического удобрения соломы люпина и инокуляции семян биопрепаратами ризоагрин или фрлавобактерин. При этом приеме увеличивается количество продуктивных стеблей, число зерен и масса зерна в колосе. Необходимо отметить, что этот максимальный в опыте уровень урожайности был достигнут без внесения минеральных азотных удобрений.

\section{Список литературы}

1.Габибов, М.А. Агропочвоведение : учебник [Текст] / М.А. Габибов, Д.В. Виноградов, Н.В. Бышов. - Рязань : ФГБОУ ВО РГАТУ, 2018. - 326 с.

2.Габибов, М.А. Агроэкологические приемы повышения продуктивности севооборота [Текст] / М.А. Габибов // Вестник Воронежского государственного аграрного университета. - 2017. - № 2 (53). - C. 40-44.

3.Габибов, М.А. Влияние биологизации и минеральных удобрений на продуктивность кукурузы [Текст] / М.А. Габибов, Е.С. Иванов // АгроЭкоИнфоo. - 2017. - № 3.

4.Габибов, М.А. Различные способы заделки удобрений [Текст] / М.А. Габибов // Земледелие. 2000. - № 4. - С. 5-6.

5.Габибов, М.А. Энергосберегающие технологии производства сельскохозяйственной продукции [Текст] / М.А. Габибов // Зерновое хозяйство. -2006. - № 2. - C. 5-6.
6. Габибов, М.А. Последействие минеральных удобрений при выращивании озимой пшеницы [Текст] / М.А. Габибов // Зерновые культуры. 2001. - № 1. - С. 11-13.

7. Костин, Я.В. Агроэкологическая эффективность биопрепарата Экстрасол при выращивании ячменя / Я.В. Костин, Р.Н. Ушаков, М.М. Крючков, О.А. Захарова, Д.В. Виноградов, Г.Н. Фадькин // Вестник Рязанского государственного агротехнологического университета им. П.А. Костычева. 2017. - № 3 (35). - С. 34-38.

8. Новикова, Н.И. Биологическая эффективность новых микробиологических препаратов алиринов Б и С для защиты растений от болезней в разных природно-климатических условиях [Текст] / И.И. Новикова, А.И. Литвиенко, И.В. Бойкова, В.А. Ярошенко, Г.В. Калько // Микология и фитопатология. - 2003. - Т. 37, Вып. 1. - С. 92-97.

9. Трунова, О.Н. Солома как прекрасное удобрение (Приготовление удобрения из соломы) [Текст] / О.Н. Трунова, В.Г. Матершев // Степные просторы. - 1993. - Т. 1. - С. 43.

10.Фадькин, Г.Н. Зависимость баланса элементов питания в системе «Почва - удобрение - растение» от форм азотных удобрений в условиях юга Нечерноземья [Текст] / Г.Н. Фадькин, Д.В. Виноградов // Вестник Красноярского государственного аграрного университета. - 2015. -№ 6 (105). - C. 13-18.

11.Федотова, М.Ю. Продуктивность овса при совместном применении удобрений и регулятора роста [Текст] / М.Ю. Федотова, Д.В. Виноградов, Г.Д. Гогмачадзе, П.Н. Балабко // АгроЭкоИнфо. 2017. - № 4 (30). - C.6.

12.Чеботарь, В.К. Микробные биопрепараты на основе эндофитных и ризобактерий, которые перспективны для повышения продуктивности и эфффективности использования минеральных удобрений у ярового ячменя и овощных культур [Текст] / В.К. Чеботарь, А.Н. Заплаткин, А.В. Щербаков, Н.В. Мальфанова, А.А. Старцева, Я.В. Костин // Сельскохозяйственная биология, 2016. - Т. 51, № 3. - С. 335 - 342.

\section{THE EFFECTIVENESS OF THE BIOLOGICAL AND MINERAL FERTILIZERS ON DARK-GRAY FOREST SOIL}

GABIBOV Magomedrasul A., Dr. of agricultural Sciences, Professor FSBEI HE "Ryazan state University named for S. A. Yessenin", Ryazan, m.gabibov@365.rsu.edu.ru.

This article discusses the impact of biological and mineral fertilizers on the productivity of winter rye on dark gray forest soil in the conditions of the Ryazan region. The studies were carried out by the method of split plots: on plots of the first order on winter rye studied the effectiveness of mineral and organic fertilizers, and on plots of the second order-the effect of biological products. The results of the research showed that the best of the studied agroecological methods of increasing the yield of winter rye is the use of lupin straw as an organic fertilizer and inoculation of seeds with biologics rizoagrin or flavobacterin. The yield of winter rye grain is from $37.5 \mathrm{C} /$ ha using rhizoagrin and up to $38.7 \mathrm{C} /$ ha from flavobacterin, on average for 3 years. Relative to the background, the increase is 6.7 and $7.9 \mathrm{C} / \mathrm{h}$ a or 21.9 and $25.5 \%$. With this agrotechnological method, the increase was obtained both by increasing the productive stems from $495 \mathrm{~W} / \mathrm{m} 2$ to $521 \mathrm{PCs} / \mathrm{m} 2$ when treated with rizoagrin and $538 \mathrm{PCs} / \mathrm{m} 2$ when treated with flavobacterin, and by increasing the weight of grain in the ear (35.1 g on the control, $37.5 \mathrm{~g}$ when treated with rizoagrin and $37.7 \mathrm{~g}$ flavobacterin). It should be noted that this maximum level of yield in the experiment was achieved without the introduction of mineral nitrogen fertilizers. In general, there is a direct correlation between nitrogen content and winter rye yield. The 
removal of essential nutrients increases with increasing yields.

Key words: mineral fertilizers, straw, biological products, rhisoagrin, flavobacterin, winter rye, yield, structure, productive stems.

\section{Literatura}

1.Gabibov, M.A. Agropochvovedenie : uchebnik [Tekst] / M.A. Gabibov, D.V. Vinogradov, N.V. Byshov. Ryazan' : FGBOU VO RGATU, 2018. - 326 s.

2. Gabibov, M.A. Agroekologicheskie priemy povysheniya produktivnosti sevooborota [Tekst] / M.A. Gabibov // Vestnik Voronezhskogo gosudarstvennogo agrarnogo universiteta. - 2017. - № 2 (53). - S. 40-44.

3.Gabibov, M.A. Vliyanie biologizacii i mineral'nyh udobrenij na produktivnost' kukuruzy [Tekst] / M.A. Gabibov, E.S. Ivanov // AgroEkolnfo. - 2017. - № 3 .

4.Gabibov, M.A. Razlichnye sposoby zadelki udobrenij [Tekst] / M.A. Gabibov // Zemledelie. - 2000. - № 4. - S. 5-6.

5. Gabibov, M.A. Energosberegayushchie tekhnologii proizvodstva sel'skohozyajstvennoj produkcii [Tekst]/ M.A. Gabibov // Zernovoe hozyajstvo. -2006. - № 2. - S. 5-6.

6. Gabibov, M.A. Posledejstvie mineral'nyh udobrenij pri vyrashchivanii ozimoj pshenicy [Tekst] / M.A. Gabibov // Zernovye kul'tury. - 2001. - № 1. - S. 11-13.

7. Kostin, YA.V. Agroekologicheskaya effektivnost' biopreparata Ekstrasol pri vyrashchivanii yachmenya / YA.V. Kostin, R.N. Ushakov, M.M. Kryuchkov, O.A. Zaharova, D.V. Vinogradov, G.N. Fad'kin // Vestnik Ryazanskogo gosudarstvennogo agrotekhnologicheskogo universiteta im. P.A. Kostycheva. - 2017. - № 3 (35). - S. 34-38.

8. Novikova, N.I. Biologicheskaya effektivnost' novyh mikrobiologicheskih preparatov alirinov B i S dlya zashchity rastenij ot boleznej v raznyh prirodno-klimaticheskih usloviyah [Tekst] / I.I. Novikova, A.I. Litvienko, I.V. Bojkova, V.A. Yaroshenko, G.V. Kal'ko // Mikologiya i fitopatologiya. - 2003. - T. 37, Vyp. 1. - S. 92-97.

9. Trunova, O.N. Soloma kak prekrasnoe udobrenie (Prigotovlenie udobreniya iz solomy) [Tekst] / O.N. Trunova, V.G. Matershev // Stepnye prostory. - 1993. - T. 1. - S. 43.

10.Fad'kin, G.N. Zavisimost' balansa elementov pitaniya v sisteme «Pochva - udobrenie - rastenie» ot form azotnyh udobrenij v usloviyah yuga Nechernozem'ya [Tekst] / G.N. Fad'kin, D.V. Vinogradov // Vestnik Krasnoyarskogo gosudarstvennogo agrarnogo universiteta. - 2015. -№ 6 (105). - S. 13-18.

11. Fedotova, M.YU. Produktivnost' ovsa pri sovmestnom primenenii udobrenij i regulyatora rosta [Tekst] / M. YU. Fedotova, D.V. Vinogradov, G.D. Gogmachadze, P.N. Balabko // AgroEkolnfo. - 2017. - № 4 (30). - S. 6.

12.Chebotar', V.K. Mikrobnye biopreparaty na osnove endofitnyh i rizobakterij, kotorye perspektivny dlya povysheniya produktivnosti i effektivnosti ispol'zovaniya mineral'nyh udobrenij u yarovogo yachmenya i ovoshchnyh kul'tur [Tekst] / V.K. Chebotar', A.N. Zaplatkin, A.V. Shcherbakov, N.V. Mal'fanova, A.A. Starceva, YA.V. Kostin // Sel'skohozyajstvennaya biologiya, 2016. - T. 51, № 3. - S. 335 - 342.

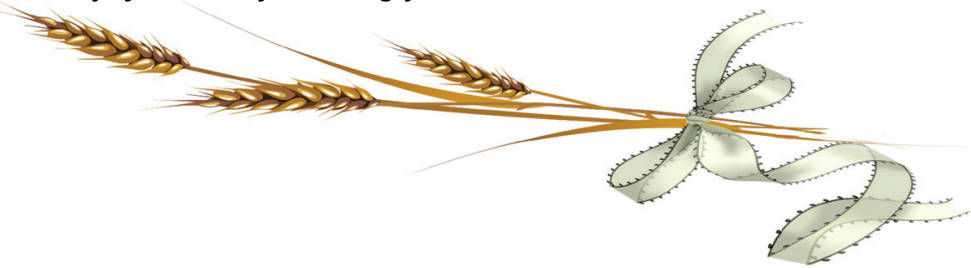

Удк 619:618.7-009.11

DOI 10.36508/RSATU.2020.45.1.004

\section{ЭФФЕКТИВНОСТЬ КОРМОВОЙ ДОБАВКИ «КАУФИТ ДРАЙ ПЛЮС» ПРИ ПРОФИЛАКТИКЕ ВНУТРЕННИХ НЕЗАРАЗНЫХ БОЛЕЗНЕЙ У КОРОВ В ПОСЛЕРОДОВОЙ ПЕРИОД}

ГЕРЦЕВА Ксения Аркадьевна, канд. биол. наук, доцент кафредры ветеринарно-санитарной экспертизы, хирургии, акушерства и внутренних болезней животных (ВСЭ, хирургии, акушерства и ВБЖ), okavet@ya.ru

ДУБОВ Дмитрий Владимирович, канд. биол. наук, доцент кафедры ВСЭ, хирургии, акушерства и ВБЖ, dmitrij.dubov2018@yandex.ru

КАДЫРОВ Алексей Владимирович, ветеринарный врач ООО «Авангард» Рязанского района Рязанской области, lelya.kadyrov@mail.ru

КИСЕЛЕВА Елена Владимировна, канд. биол.наук, доцент кафедры ВСЭ, хирургии, акушерства и ВБЖ, super.juliakiseleva2013@yandex.ru

СИТчИХИнА Алена Владимировна, лаборант кафредры ВСЭ, хирургии, акушерства и ВБЖ, sit4ihina@yandex.ru

Рязанский государственный агротехнологический университет имени П. А. Костычева

В научной работе изучена эфффрективность профрилактики внутренних незаразных болезней в послеродовом периоде у коров путем введения в рацион глубоко сухостойных коров кормовой добавки «Кауфрит драй плюс». Эффрективность кормовой добавки оценивали, анализируя частоту

(ㄷ Герцева К. А., Дубов Д. В., Кадыров А. В., Киселева Е. В., Ситчихина А. В., 2020 г. 
встречаемости незаразной патологии, данные фризикального осмотра, морфологические и биохимические изменения в крови, рН-мочи и рубцовой жидкости. Исследования проводились на двух группах аналогов глубоко сухостойных коров (контрольная и опытная). Было установлено, что на 21-й день после отела в опытной группе по сравнению с контролем достоверно уменьшилась частота встречаемости: задержания последа на 11,7\%, послеродового эндометрита на 10,0\%, родильного пареза на 8,3\%, клинического мастита на 8,4\%. Однако случаи заболевания смещения сычуга за исследуемый период в опытной группе увеличились на 1,6\%, кетоза - на 3,3\%, гипотонии рубца - на 3,3\%, асептических болезней копыт - на 4,9\%. В опытной группе отмечено достоверное по-

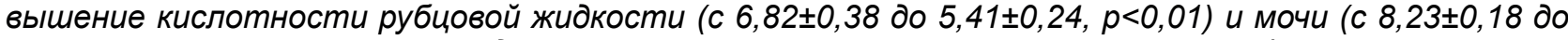

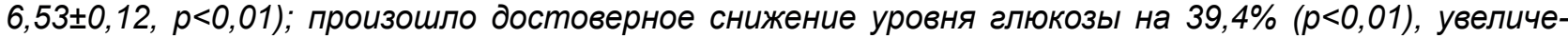
ние содержания кетоновых тел в 2,8 раза, повышение уровня кальция и фоосфора на 22,4 и 18,2\% $(p<0,05)$ соответственно. Обнаруженные изменения в биохимическом профриле крови исследуемых коров свидетельствуют о развитии энергетического дефицита в организме коров опытной группы и развитии гипокальциемии в организме коров контрольной группы. Применение кормовой добавки «Кауфит Драй плюс» достоверно снижает риск развития гипокальциемии, родильного пареза, послеродового эндометрита, задержания последа и клинического мастита, но увеличивает риск развития таких болезней в послеродовом периоде как гипотония рубца, кетоз, смещение сычуга, асептических болезней копыт.

Ключевые слова: крупный рогатый скот, родильный парез, анионные соли, сухостойные коровы, профилактика.

\section{Введение}

В практической деятельности ветеринарного клинициста ведущее место должна занимать групповая профиллактика и групповая терапия болезни в предклинический период [11,13]. Такой подход является наиболее эфффективным как с врачебной, так и с экономической точек зрения. Одним из основополагающих звеньев в профилактике внутренних незаразных болезней является полноценное кормление $[1,4]$. Задача кормления в период позднего сухостоя (за 20 дней до отела) - подготовить корову к лактации, для чего требуется следить за потреблением сухого вещества, формированием рубцовой микрофлоры и предотвращением нарушений обмена веществ $[2,8]$. При несбалансированном витаминно-минеральном питании у коров в сухостойный период с большей вероятностью после отела могут развиться послеродовой парез, мастит, эндометрит, кетоз и другие заболевания [3,6]. Отличие кормовой добавки «Кауфит Драй плюс» заключается в дополнительном включении в рацион анионных солей. По мнению специалистов, анионовый рацион помогает регулировать энергетический баланс, повышая потребление сухого вещества благодаря улучшению гомеостаза кальция $[5,7]$. Кормление с использованием анионных солей снижает $\mathrm{pH}$ крови, вызывая метаболический ацидоз и активизируя действие паратиреоидного гормона. В результате увеличивается высвобождение кальция из костяка и выработка 1,25-дигидроксивитамина $\mathrm{D}$, повышающего абсорбцию кальция в кишечнике $[10,12]$. Обмен кальция напрямую влияет на возникновение таких болезней как послеродовой парез, мастит, эндометрит и др. [9, 14]. В связи с этим изучение влияния кормовой добавки «Кауфит Драй плюс» на частоту встречаемости внутренних незаразных болезней является актуальной задачей для интенсивного животноводства.

Цель работы: изучить влияние кормовой добавки «Кауфит Драй плюс» в рационе глубокосухостойных коров на частоту встречаемости внутренних незаразных болезней в послеродовой период.

\section{Материалы и методы исследований}

Научно-практическая работа была выполнена в зимне-весенний период 2019 года. Лабораторные исследования были проведены на кафедре ВСЭ, хирургии, акушерства и ВБЖ ФГБОУ ВО Рязанского ГАТУ, в ГБУ РО «Рязанская облветлаборатория». Научно-производственный опыт был поставлен в животноводческом хозяйстве ООО «Авангард» (5-е отделение, с. Подвязье) Рязанского района Рязанской области (рис. 1). В процессе исследования была проанализирована ветеринарная документация для установления частоты встречаемости внутренних незаразных заболеваний в послеродовой период 2016-2018 гг. Объектом исследования являлись коровы. Для изучения профилактической эффективности применения кормовой добавки «Кауфит драй плюс» и установления частоты встречаемости незаразной патологии в послеродовой период были сформированы две группы глубоко сухостойных коров (опытная и контрольная) $(\mathrm{n}=60)$. В опытной и контрольной группах животных общий уровень кормления был одинаковым, разница к норме не превышала $\pm 5 \%$. Рацион глубоко сухостойных животных был сбалансирован по всем показателям и состоял из силоса кукурузного (10 кг), сенажа «горох-овес» (8 кг), сенажа «люцерна + клевер» (3 кг), соломы ячменной (2 кг), кукурузы $(0,4$ кг) и комбикорма КК СУХ2 (4 кг). В опытной группе дополнительно за 25 дней до предполагаемого отела коровам давали кормовую добавку «Кауфит Драй плюс» («Мустанг Технологии») по 200 г в сутки на голову.

Кормовая добавка содержит в своем составе витамины и минералы, а также анионные соли (табл. 1). Изучение клинического состояния животных, установление морфологических и био-

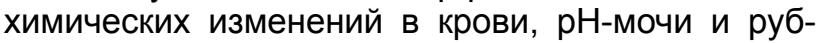
цовой жидкости проводилось на двух группах аналогов глубоко сухостойных коров (контрольная и опытная) (n=16) (2-я лактация, живая масса 600-650 кг, голштино-фрризская порода, продуктивность 7500-8000 тыс.кг молока за 305 дней лактации). 


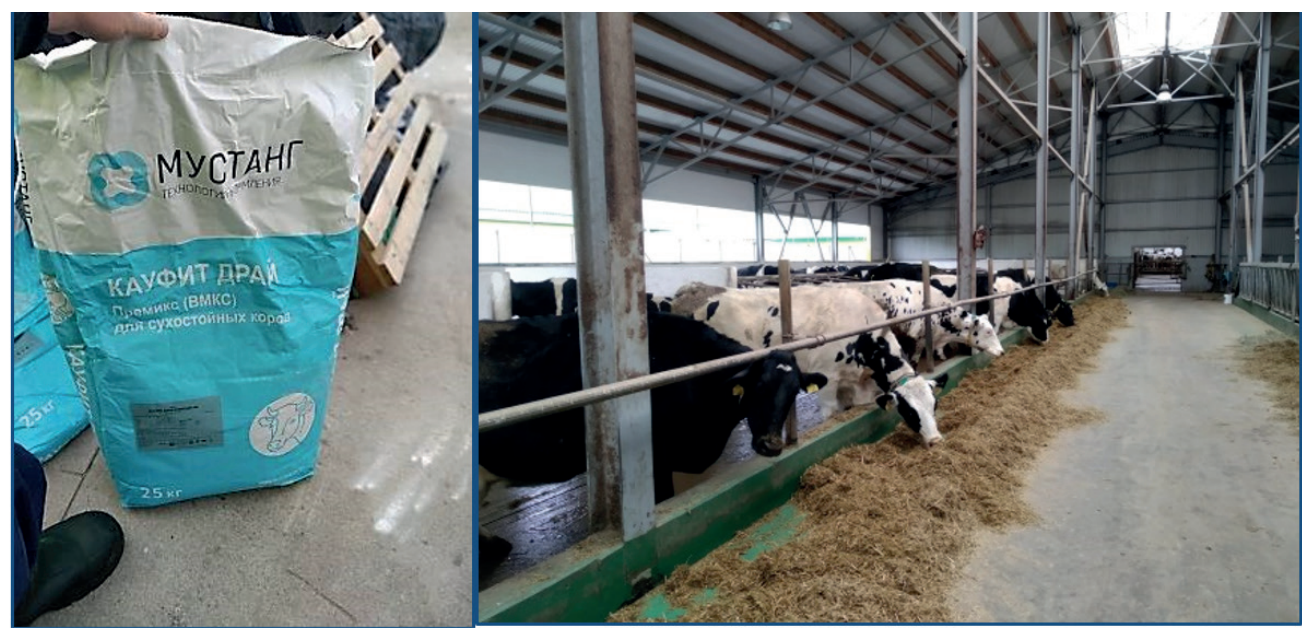

Рис.1 - ООО «Авангард» 5-е отделение с. Подвязье. Применение кормовой добавки «Кауфит Драй Плюс» в рационе сухостойных коров

Таблица 1 - Состав премикса Кауфит Драй Плюс в 1 кг продукта.

\begin{tabular}{|l|c|l|c|}
\hline \multicolumn{1}{|c|}{ Показатель } & Количество & \multicolumn{1}{c|}{ Показатель } & Количество \\
\hline Витамин А, тыс. ИЕ & 450 & Кобальт, мг & 40 \\
\hline Витамин Д, тыс. ИЕ & 150 & Йод, мг & 75 \\
\hline Витамин Е, тыс. ИЕ & 8000 & Селен, мг & 45 \\
\hline Витамин Н, мг & 50 & Магний, г & 40 \\
\hline Медь, мг & 1100 & Ионофор & вкл. \\
\hline Цинк, мг & 5000 & Анионные соли & вкл. \\
\hline Марганец, мг & 3500 & $\begin{array}{l}\text { Анионно-катионный ба- } \\
\text { ланс мг-экв }\end{array}$ & 1200 \\
\hline
\end{tabular}

За 25 дней до отела и на 21-й день (послеродовой период) после отела у коров проводили клиническое исследование, включающее морфологический и биохимический анализ крови, клинический анализ мочи, исследование на субклинический мастит. Клинический осмотр проводили по общепринятой в ветеринарии методике, включающей обязательную термометрию. Кровь у животных отбирали из хвостовой вены рано утром до кормления. Исследования цельной крови проводили на гематологическом анализаторе «Abacus junior vet 1.22» (DIATRON), исследования сыворотки крови проводили на биохимическом и иммуноферментном автоматическом анализаторе "Chem Well combo». Лейкограмму исследовали путем подсчета 200 лейкоцитов разных видов, окрашенных по Романовскому-Гимзе с вычислением процентного соотношения каждого вида. Рубцовую жидкость отбирали с помощью руминоцентеза путем пункции вентрального мешка рубца утром до кормления; $\mathrm{pH}$-метрию рубцовой жидкости и мочи определяли с помощью $\mathrm{pH}$-метра ( $\mathrm{pH}$-метр $150 \mathrm{MИ}$ ). Достоверность результатов подтверждали путем статистической обработки и определения различий средних значений с помощью критерия Стьюдента.

\section{Результаты исследований}

Проведенным анализом ветеринарной документации животноводческого комплекса установлено, что с 2016 по 2018 годы такие заболевания у коров как задержание последа, послеродовой эндометрит, родильный парез имели ежегодную тенденцию к нарастанию (табл. 2).

Таблица 2 - Распространение незаразных болезней в послеродовой период у коров

\begin{tabular}{|l|c|c|c|}
\hline \multirow{2}{*}{ Патология, \% } & \multicolumn{3}{|c|}{ Период наблюдения, годы } \\
\cline { 2 - 4 } & 2016 & 2017 & 2018 \\
\hline Родильный парез & 3,0 & 10,1 & 14,2 \\
\hline Задержание последа & 8,1 & 11,1 & 15,0 \\
\hline $\begin{array}{l}\text { Послеродовой эндоме- } \\
\text { трит }\end{array}$ & 6,5 & 42,4 & 44,2 \\
\hline Клинический мастит & 28,3 & 39,4 & 35,0 \\
\hline Кетоз & 4,0 & 9,0 & 4,3 \\
\hline Смещение сычуга & 3,0 & 5,2 & 4,5 \\
\hline Гипотония рубца & 6,8 & 10,3 & 7,2 \\
\hline $\begin{array}{l}\text { Асептические болезни } \\
\text { копыт }\end{array}$ & 9,2 & 19,1 & 22,4 \\
\hline
\end{tabular}


Обнаруженное увеличение числа случаев послеродовых болезней побудило ветеринарную службу фермы применять анионные соли (кормовую добавку «Кауфит Драй плюс») в кормовом рационе в качестве профилактической меры. В сравнительном аспекте опытной и контрольной групп была установлена профилактическая эффективность кормовой добавки «Кауфит Драй плюс» при профилактике незаразных болезней послеродового периода: родильного пареза, задержания последа, послеродового эндометрита, клинического мастита, смещения сычуга, гипотонии рубца, асептических болезней копыт. В ходе научно-исследовательской работы было установлено, что на 21-й день после отела в опытной группе по сравнению с контролем достоверно уменьшилась частота встречаемости задержания последа на $11,7 \%$, послеродового эндометрита на $10,0 \%$, родильного пареза на $8,3 \%$ (в опытной группе не зафиксировано ни одного случая родильного пареза), клинического мастита на 8,4\%. Однако случаи заболевания смещением сычуга за исследуемый период в опытной группе увеличились на 1,6\%, кетоза - на 3,3\%, гипотонии рубца на 3,3\%, асептических болезней копыт - на 4,9\% (рис. 2). Мы предполагаем, что смещению сычуга, развитию кетоза, гипотонии рубца и появлению асептических болезней копыт у коров опытной группы способствовало изменение рубцового пищеварения вследствие развития метаболического ацидоза.

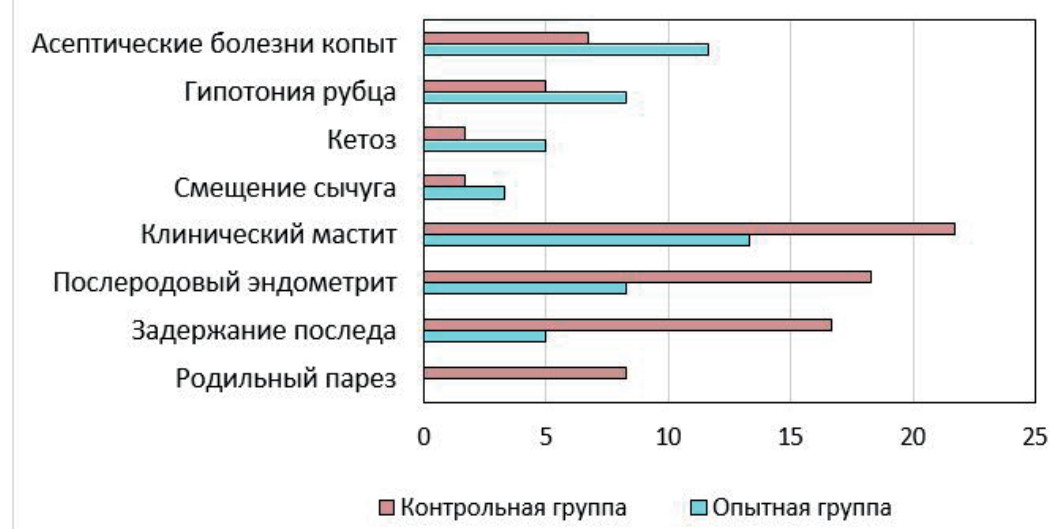

Рис. 2 - Частота встречаемости незаразной патологии у коров в послеродовой период при применение кормовой добавки «Кауфит Драй плюс», \%

Установлено, что за 25 дней до отела клиническое состояние у всех животных было в пределах физиологической нормы (табл. 3). Стоит отметить, что на 21-й день после отела в опытной группе по сравнению с показателями до отела было отмечено достоверное повышение температуры тела (с $37,52 \pm 0,16^{\circ} \mathrm{C}$ до $\left.38,96 \pm 0,15^{\circ} \mathrm{C}, \mathrm{p}<0,05\right)$.

Таблица 3 - Показатели фризикального осмотра коров до отела и на 21-й день после отела при применении кормовой добавки «Кауфит Драй плюс»

\begin{tabular}{|l|c|c|c|c|}
\hline \multirow{2}{*}{\multicolumn{1}{|c|}{ Показатели }} & \multicolumn{4}{|c|}{ Группы $(\mathrm{n}=16)$} \\
\cline { 2 - 5 } & \multicolumn{2}{|c|}{ до отела } & \multicolumn{2}{c|}{ после отела } \\
\cline { 2 - 5 } & опыт & контроль & опыт & контроль \\
\hline Температура, ${ }^{\circ} \mathrm{C}$ & $37,52 \pm 0,16$ & $37,48 \pm 0,18$ & $38,96 \pm 0,15^{*}$ & $37,98 \pm 0,34$ \\
\hline $\begin{array}{l}\text { Частота сердечных } \\
\text { сокращений, в минуту }\end{array}$ & $68,29 \pm 2,03$ & $66,43 \pm 1,25$ & $78,81 \pm 2,56^{* *}$ & $70,22 \pm 1,35^{*}$ \\
\hline $\begin{array}{l}\text { Частота дыхательных } \\
\text { движений, дых.дв./мин }\end{array}$ & $20,24 \pm 0,84$ & $21,35 \pm 0,32$ & $23,22 \pm 0,55^{\star *}$ & $22,55 \pm 0,28$ \\
\hline Руминация, сокр. /2 мин. & $5,21 \pm 0,28$ & $5,54 \pm 0,25$ & $3,25 \pm 0,35^{*}$ & $5,38 \pm 0,32$ \\
\hline рН рубцовой жидкости & $6,82 \pm 0,38$ & $6,93 \pm 0,25$ & $5,41 \pm 0,24^{* *}$ & $6,54 \pm 0,20$ \\
\hline рН мочи & $8,23 \pm 0,18$ & $8,42 \pm 0,15$ & $6,53 \pm 0,12^{* *}$ & $7,93 \pm 0,18$ \\
\hline
\end{tabular}

Примечание: разница показателей достоверна: * $-p<0,05 ;{ }^{* *}-p<0,01$ по сравнению с показателями до отела

Мы установили, что на 2-й день после отела частота сердечных сокращений достоверно увеличилась как в опытной, так и в контрольной груп- пах на $15,4 \%$ и 5,7\% соответственно ( $p<0,01)$. По мнению исследователей, это связано с активизацией обмена веществ в послеродовой период у 
коров и преобладанием процессов катаболизма над анаболизмом [15]. Частота дыхательных движений достоверно увеличилась в опытной группе на $14,7 \%$ по сравнению с показателями до отела $(p<0,01)$. Установлено снижение частоты рубцовых сокращений в опытной группе на 2-й день

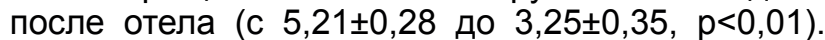
Отмечено достоверное повышение кислотности рубцовой жидкости в опытной группе на 21-й день

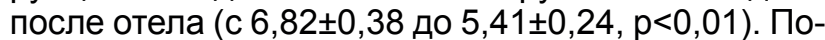
казатель $\mathrm{pH}$ мочи в опытной группе на 21-й день

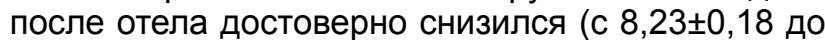
$6,53 \pm 0,12, p<0,01)$. Обнаруженные изменения в клиническом состоянии животных опытной группы после отела говорят о развитии у животных метаболического ацидоза, требующего срочной коррекции рациона. В контрольной группе по таким показателям как частота дыхательных движений, изменение $\mathrm{pH}$ рубцовой жидкости и $\mathrm{pH}$ мочи по сравнению с показателями до отела достоверных изменений отмечено не было.

В дальнейшем мы установили изменения гематологического профиля у коров и выяснили, что на 21-й день после отела произошли следующие достоверные изменения: уменьшение количества гемоглобина в опытной группе на $9,9 \%$ $(p<0,01)$, повышение количества лейкоцитов на $41,4 \%(p<0,01)$ в опытной группе и на 20,5\% в контрольной группе ( $<<0,05)$; увеличение количества эозинофилов на $64,7 \%(p<0,01)$ в опытной группе, увеличение количества палочкоядерных нейтрофиллов в 2,57 раза $(p<0,01)$ в опытной группе и в 1,66 раза $(p<0,01)$ в контрольной группе; уменьшение числа лимфоцитов на $18,3 \%$ в опытной группе $(p<0,05)$ и на $11,5 \%(p<0,05)$ в контрольной группе; увеличение количества моноцитов в 1,33 раза в опытной группе $(p<0,01)$ и в 1,28 раза в контрольной группе ( $<<0,01)$ (табл. 4).

Таблица 4 - Морфологические показатели крови коров до и после отела

\begin{tabular}{|c|c|c|c|c|c|}
\hline \multirow{3}{*}{ Показатели } & \multirow{3}{*}{$\begin{array}{c}\text { Норма со- } \\
\text { гласно данным } \\
\text { МВА, ВНИ- } \\
\text { ИГРЖ }\end{array}$} & \multicolumn{4}{|c|}{ Группы (n=16) } \\
\hline & & \multicolumn{2}{|c|}{ до отела } & \multicolumn{2}{|c|}{ после отела } \\
\hline & & опыт & контроль & опыт & контроль \\
\hline Эритроциты, млн & $5,0-7,5$ & $5,32 \pm 0,25$ & $5,28 \pm 0,34$ & $5,43 \pm 0,32$ & $5,56 \pm 0,28$ \\
\hline Гемоглобин, г/л & $90-120$ & $100,5 \pm 3,52$ & $90,6 \pm 3,28^{*}$ & $99,2 \pm 3,76$ & $89,4 \pm 3,02$ \\
\hline Лейкоциты, тыс. & $4,5-12$ & $8,59 \pm 0,86$ & $12,15 \pm 0,94^{* *}$ & $9,14 \pm 0,65$ & $11,01 \pm 0,46^{*}$ \\
\hline Базофрилы, \% & $0-2$ & $0,1 \pm 0,04$ & $0,1 \pm 0,05$ & $0,1 \pm 0,07$ & $0,1 \pm 0,05$ \\
\hline Эозинофилы,\% & $3-10$ & $6,8 \pm 0,65$ & $11,2 \pm 0,86^{\star \star}$ & $7,9 \pm 0,58$ & $9,5 \pm 0,72$ \\
\hline $\begin{array}{l}\text { Нейтрофилы, \%, в т.ч. } \\
\text { юные }\end{array}$ & $0-1$ & $0,1 \pm 0,05$ & $0,2 \pm 0,08$ & $0,1 \pm 0,06$ & $0,2 \pm 0,04$ \\
\hline палочкоядерные & $2-5$ & $4,9 \pm 0,44$ & $12,6 \pm 1,82^{* *}$ & $5,9 \pm 0,94$ & $9,8 \pm 0,86^{\star *}$ \\
\hline сегментоядерные & $20-35$ & $34,5 \pm 1,85$ & $29,3 \pm 1,76$ & $34,4 \pm 1,56$ & $32,7 \pm 1,63$ \\
\hline Лимфоциты,\% & $40-75$ & $48,2 \pm 2,96$ & $39,4 \pm 2,88^{*}$ & $46,6 \pm 1,78$ & $41,2 \pm 1,82^{*}$ \\
\hline Моноциты, \% & $2-7$ & $5,4 \pm 0,28$ & $7,2 \pm 0,42^{\star *}$ & $5,0 \pm 0,24$ & $6,4 \pm 0,38^{\star *}$ \\
\hline
\end{tabular}

Примечание: разница показателей достоверна: * $-p<0,05 ;$ ** $-p<0,01$ по сравнению с показателями до отела

Мы предполагаем, что установленные изменения морфологического состава крови прежде всего свидетельствуют о физиологических изменениях, характерных для послеродового периода. Однако в опытной группе обнаружен лейкоцитоз в 2 раза выше, чем в контроле; наблюдается повышение числа эозинофилов. Мы связываем эти изменения с началом развития метаболического ацидоза. При изучении биохимических показателей крови установлено, что на 21-й день после отела в опытной группе произошло достоверное увеличение альбуминов на $8,2 \%$ в контрольной на $12,2 \%(p<0,05)$. Общий белок в опытной группе достоверно поднялся на $5,2 \%$ в опытной группе, на 10,2\% в контрольной группе ( $p<0,05)$.

Таблица 5 - Биохимические показатели крови коров до и после отела

\begin{tabular}{|c|c|c|c|c|c|}
\hline \multirow[t]{3}{*}{ Показатели } & \multirow{3}{*}{$\begin{array}{c}\text { Норма со- } \\
\text { гласно данным } \\
\text { МВА, } \\
\text { ВНИИГРЖ }\end{array}$} & \multicolumn{4}{|c|}{ Группы $(n=16)$} \\
\hline & & \multicolumn{2}{|c|}{ до отела } & \multicolumn{2}{|c|}{ после отела } \\
\hline & & опыт & контроль & опыт & контроль \\
\hline Альбумины, г/л & $30-40$ & $34,3 \pm 1,14$ & $35,1 \pm 1,56$ & $37,1 \pm 1,23$ & $39,4 \pm 1,48$ \\
\hline Общий белок, г/л & $70-89$ & $76,7 \pm 2,68$ & $75,8 \pm 3,14$ & $80,7 \pm 3,22$ & $83,5 \pm 2,15$ \\
\hline Глюкоза, ммоль/л & $2,2-3,3$ & $3,4 \pm 0,16$ & $3,6 \pm 0,28$ & $2,0 \pm 0,39^{* *}$ & $2,5 \pm 0,32^{*}$ \\
\hline b-кетоны, ммоль/л & $0,3-1,0$ & $1,0 \pm 0,35$ & $0,9 \pm 0,04$ & $2,8 \pm 0,36$ & $1,1 \pm 0,05$ \\
\hline Са, ммоль/л & $2,6-3,5$ & $2,32 \pm 0,15$ & $2,48 \pm 0,18$ & $2,84 \pm 0,12^{* *}$ & $2,01 \pm 0,12^{* *}$ \\
\hline Р, ммоль/л & $1,29-2,25$ & $1,15 \pm 0,06$ & $1,21 \pm 0,08$ & $1,36 \pm 0,08^{*}$ & $1,15 \pm 0,10$ \\
\hline Калий, ммоль/л & $3,2-5,8$ & $4,38 \pm 0,25$ & $4,48 \pm 0,20$ & $4,85 \pm 0,28$ & $5,12 \pm 0,23^{*}$ \\
\hline
\end{tabular}


Продолжение таблица 5

\begin{tabular}{|l|c|c|c|c|c|}
\hline Натрий, ммоль/л & $130-155$ & $135,7 \pm 3,86$ & $136,8 \pm 3,82$ & $133,8 \pm 4,55$ & $135,5 \pm 4,22$ \\
\hline $\begin{array}{l}\text { Резервная щелочность, } \\
\text { об\% СО2 }\end{array}$ & $46-66$ & $46,3 \pm 2,54$ & $45,2 \pm 1,72$ & $38,2 \pm 2,56$ & $42,3 \pm 2,24$ \\
\hline АЛТ, Ед/л & $6,9-35,5$ & $25,5 \pm 1,48$ & $23,8 \pm 1,25$ & $32,5 \pm 1,35$ & $27,7 \pm 1,32$ \\
\hline АСТ, Ед/л & $45-120$ & $106,8 \pm 5,25$ & $111,6 \pm 3,56$ & $138,4 \pm 6,12$ & $127,6 \pm 4,12$ \\
\hline
\end{tabular}

Примечание: разница показателей достоверна: * $-p<0,05 ;{ }^{* *}-p<0,01$ по сравнению с показателями до отела

Анализ содержания глюкозы выявил, что на 21-й день после отела произошло достоверное снижение уровня глюкозы в опытной группе на $39,4 \%(p<0,01)$, в контрольной группе на 30,5\% $(p<0,05)$. Мы предполагаем, что такие изменения углеводного обмена свидетельствуют об отрицательном балансе энергии в новотельный период. В опытной группе достоверно увеличилось содержание кетоновых тел в 2,8 раза, в то время как в контрольной группе уровень кетоновых тел остался на пограничном уровне и составил $1,1 \pm 0,05$ ммоль/л $(p<0,01)$. В послеродовой период уровень кальция и фосфора в опытной группе оказался выше показателей до отела на 22,4\% и на $18,2 \%(p<0,05)$ соответственно, в то время как в контрольной группе уровень кальция снизился на $19,0 \%$, а фоосфор достоверно не изменился. Стоит отметить, что соотношение Сa:P в опытной группе - в пределах нормы и этот показатель равен 2,08, в то время как в контрольной группе снизился и вышел за пределы референсных значений и стал равным 1,74, что говорит о развитии гипокальциемии. Анализ содержания калия установил, что этот показатель достоверно увеличился после отела только в контрольной группе на 14,2\%. Достоверных изменений по содержанию натрия во всех группах отмечено не было. Изучая показатели кислотно-щелочного равновесия, установили достоверное снижение резервной щелочности в опытной группе в послеродовой период на $17,5 \%$ в опытной группе $(p<0,05)$. Ферментативная активность АЛТ увеличилась в опытной группе на $27,5 \%$, в контрольной - на $17,9 \%$, АСТ - на $29,6 \%$ в опытной группе и на $14,3 \%$ в контрольной. Данные изменения в биохимическом профиле свидетельствуют о развитии энергетического дефицита в организме коров в опытной группе и о развитии гипокальциемии в организме коров в контрольной группе.

\section{Выводы}

На основании полученных результатов проведенного опыта можно сделать вывод, что введение кормовой добавки «Кауфит Драй плюс» в рацион глубоко сухостойных коров позволяет существенно снизить вероятность возникновения в послеродовом периоде родильного пареза, эндометрита, мастита, задержания последа, т.к. в крови происходит увеличение содержания кальция. Однако применение кормовой добавки «Кауфит Драй плюс» увеличивает риск развития таких болезней в послеродовом периоде как гипотония рубца, кетоз, смещение сычуга, асептических болезней копыт, т.к. на 21-й день после отела, если не вводить дополнительные корректирующие пре- миксы, возникают предпосылки образования некомпенсируемого метаболического ацидоза.

\section{Список литературы}

1. Быстрова, И. Ю. Влияние технологических факторов на состояние копытец коров в условиях интенсивного производства молока [Текст] / И.Ю. Быстрова // Вестник РГАТУ, № 2, 2016. - С.5-7.

2. Дубов, Д.В. Образование ЛЖК в рубце коров в зависимости от подготовки зерновой части рациона [Текст] / Дубов Д.В., Кулаков В.В. // Материалы Всероссийской научно-практической конференции, посвященной 70-летию факультета ветеринарной медицины и биотехнологии «Актуальные проблемы и приоритетные направления животноводства», 2019. - С.15-19.

3. Каширина, Л. Г. Влияние антиоксидантов на продуктивность и качество молока коров [Текст] / Л.Г. каширина, К.А. Иванищев, К.И. Романов // Мат. Всероссийской научно-методической конференции с международным участием, посвященная 100-летию академика Д.К. Беляева «Аграная наука в условиях модернизации и инновационного развития», 2017. - С.266-271.

4. Кондакова, И.А., Фитопрепарат для инактивации микотоксинов, возникающих в зерновой массе [Текст] / В.И. Левин, И.П. Льгова., Ю.В. Ломова // Вестник РГАТУ, № 4, 2018. - С.18-23.

5. Крупин, Е. О., Молочная продуктивность, состав и качество молока высокопродуктивных коров на фоне направленного регулирования обмена веществ журнал / Е.О Крупин, М.Г. Зухрабов, Ш.К. Шакиров // Ученые записки Казанской государственной академии ветеринарной медицины им. Н.Э. Баумана, 2010. - С.134-140. - Режим доступа: https://www.agroxxi.ru/zhivotnovodstvo/stati/ programma-kormlenija-korov-v-suhostoinyi-periodmustang-tehnologii-kormlenija-sohranit-zdorovekorovy-telenka-i-priumnozhit-molochnuyu-produktivnost.html

6. Остякова, М. Е. Послеродовая гипокальциемия коров и ее профилактика [Текст] / М.Е. Остякова, Н. Н. Малкова, В.К. Ирхина, Н.С. Голайдо // Дальневосточный вестник, 2016. - С. 60-65.

7. Крюков, В. С. Влияние электролитного баланса на коров [Текст] / В. С. Крюков // ГК АгроБалт трейд, Санкт-Петербург. - 2011. - с. 8-12.

8. Микко, А. Правильное кормление кормление до и после отела [Текст] / А. Микко., О. В. Овчинникова // Животноводство России. - Март, 2012. - С. 38-39.

9. Матвеева А.В. Особенности гематологического профиля крупного рогатого скота в условиях стресса, вызванного патологическими процессами в области дистального отдела конечностей [Текст] 
/ А.В. Матвеева, Э.О. Сайтханов // Материалы Национальной научно-практической конференции «Приоритетные направления научно-технологического развития агропромышленного комплекса России». - Рязань: РГАТУ. 2019. - С. 193-199.

10. Захаров, В.А. Научное сопровождение эффективного ведения воспроизводства крупного рогатого скота [Текст] / В.А. Захаров, О.В. Баковекая, Е.В. Киселева // АПК достижения науки и техники. - 2015. -№ 3 - С. 51-54.

11. Редкозубова, В. И. Профрилактика гипокальциемии у коров [Текст] / В. И. Редкозубова // Животноводство России. Тематический выпуск. 2018 год. - С. 58-60.

12. Сайтханов, Э.О. Изучение частоты регистрации и характера патологии копытец в животноводческом хозяйстве с беспривязным содержанием [Текст] / Э.О. Сайтханов, Д.С. Беседин, А.В. Рудная // Вестник РГАТУ, № 3, 2018. - С.62-67.
13. Сусанна Тауриайнен Катионно-анионный баланс в кормах и потребление кальция и магния у стельных коров [Текст] / С. Тауриайнен С. // Хельсинкский университет Кафедра животноводства. 2001. - С. 48-52.

14. Mecitoglu, Z. Prepartum urine $\mathrm{pH}$ as a predictor of left displacement of abomasum / $Z$. Mecitoglu, S. Senturk, C. Kara, G. Akgul, E. Uzabacı // The Journal of Animal \& Plant Sciences, 26(2): 2016, Page: 320-324.

15. Gelfert, A. Impact of a prolonged period of feeding anionic saltson the acid-base-balance and calcium metabolism ofdairy cows / A.Löptien, C-C. Gelfert, A. N. Montag, W. Baumgartner, R. Staufenbiel // Vet. Med. Austria, Wien.Tierärztl. Mschr. 93 (2006), 304 - 310 - https://www.researchgate.net/ publication/289048835 Impact of a prolonged period_of_feeding_anionic_salts_on the acid-basebalance_and_calcium_metabolism_of_dairy_cows/

\section{THE EFFECTIVENESS OF FEED ADDITIVES "KOUPIT DRY PLUS" IN THE PREVENTION OF INTERNAL NON-CONTAGIOUS DISEASES OF THE POSTPARTUM PERIOD IN COWS}

Gertseva Ksenia A., C.b.N., associate Professor, head of the Department of veterinary and sanitary examination, surgery, obstetrics and internal diseases of animals, okavet@ya.ru

Dubov Dmitry V., C.b.N., associate Professor, head of the Department of veterinary and sanitary examination, surgery, obstetrics and internal diseases of animals, dmitrij.dubov2018@yandex.ru

Kadyrov Alexey V., veterinarian, OOO "Vanguard" of Ryazan region Ryazan region, lelya.kadyrov@mail.ru.

Kiseleva Elena V., C.b.N., associate Professor, head of the Department of veterinary and sanitary examination, surgery, obstetrics and internal diseases of animals,super.juliakiseleva2013@yandex.ru

Sitchikhina Alena V., assistant, head of the Department of veterinary and sanitary examination, surgery, obstetrics and internal diseases of animals Sit4ihina@yandex.ru

Ryazan state agrotechnological University named after P. A. Kostychev

The effectiveness of prevention of internal non-contagious diseases in the postpartum period in cows due to the introduction of a feed additive "Kaufit Dry Plus" into the diet of deeply dry cows was studied in the scientific work. The effectiveness of the feed additive was evaluated by analyzing the incidence of non-infectious pathology, physical examination data, morphological and biochemical changes in blood, $\mathrm{pH}$-urine and scar fluid. Studies were carried out on two groups of analogues of deeply dry cows (control and experimental). It was determined that on 21 days after calving in the experimental group, compared with the control: placenta retention by $11.7 \%$, postpartum endometritis by $10.0 \%$, puerperal paresis by $8.3 \%$, clinical mastitis by $8.4 \%$. However, cases of abomasal displacement during the study period in the experimental group increased by $1.6 \%$, ketosis - by 3.3\%, scar hypotension - by 3.3\%, aseptic hoof diseases-by $4.9 \%$. In the experimental group, there was a significant increase in the acidity of scar fluid (from $6.82 \pm 0.38$ to $5.41 \pm 0.24, p<0.01$ ) and urine (from $8.23 \pm 0.18$ to $6.53 \pm 0.12, p<0.01$ ); there was a significant decrease in glucose level by $39.4 \%$ $(p<0.01)$, an increase in the content of ketone bodies by 2.8 times, an increase in calcium and phosphorus by $22.4 \%$ and $18.2 \%(p<0.05)$, respectively. The detected changes in the biochemical profile of the blood of the studied cows indicate the development of energy deficiency in the body of cows of the experimental group and the development of hypocalcemia in the body of cows of the control group. The use of the feed additive "Kaufit Dry Plus" significantly reduces the risk of hypocalcemia, puerperal paresis, postpartum endometritis, retention of the afterbirth and clinical mastitis, but increases the risk of such diseases in the postpartum period such as hypotension of the scar, ketosis, displacement of the rennet, aseptic diseases of the hooves.

Key words: cattle, maternity paresis, anionic salts, dry cows, prevention.

\section{Literatura}

1. Bystrova, I. YU. Vliyanie tekhnologicheskih faktorov na sostoyanie kopytec korov $v$ usloviyah intensivnogo proizvodstva moloka [Tekst] / I. YU. Bystrova // Vestnik RGATU, № 2, 2016. - S.5-7.

2. Dubov, D.V. Obrazovanie LZHK v rubce korov v zavisimosti ot podgotovki zernovoj chasti raciona [Tekst] / Dubov D.V., Kulakov V.V. I/ Materialy Vserossijskoj nauchno-prakticheskoj konferencii, posvyashchennoj 70-letiyu fakul'teta veterinarnoj mediciny i biotekhnologii «Aktual'nye problemy i prioritetnye napravleniya zhivotnovodstva», 2019. - S.15-19.

3. Kashirina, L. G. Vliyanie antioksidantov na produktivnost' i kachestvo moloka korov [Tekst] / L.G. kashirina, K.A. Ivanishchev, K.I. Romanov // Mat. Vserossijskoj nauchno-metodicheskoj konferencii s mezhdunarodnym uchastiem, posvyashchennaya 100-letiyu akademika D.K. Belyaeva "Agranaya nauka v 
usloviyah modernizacii i innovacionnogo razvitiya», 2017. - S.266-271.

4. Kondakova, I.A., Fitopreparat dlya inaktivacii mikotoksinov, voznikayushchih v zernovoj masse [Tekst] / V.I. Levin, I.P. L'gova., YU.V. Lomova // Vestnik RGATU, № 4, 2018. - S.18-23.

5. Krupin, E. O., Molochnaya produktivnost', sostav i kachestvo moloka vysokoproduktivnyh korov na fone napravlennogo regulirovaniya obmena veshchestv zhurnal / E.O Krupin, M.G. Zuhrabov, SH.K. SHakirov // Uchenye zapiski Kazanskoj gosudarstvennoj akademii veterinarnoj mediciny im. N.E. Baumana, 2010. - S.134-140. - Rezhim dostupa: https://www.agroxxi.ru/zhivotnovodstvo/stati/programma-kormlenijakorov-v-suhostoinyi-period-mustang-tehnologii-kormlenija-sohranit-zdorove-korovy-telenka-i-priumnozhitmolochnuyu-produktivnost.html

6. Ostyakova, M. E. Poslerodovaya gipokal'ciemiya korov i ee profilaktika [Tekst] / M.E. Ostyakova, N. N. Malkova, V.K. Irhina, N.S. Golajdo // Dal'nevostochnyj vestnik, 2016. - S. 60-65.

7. Kryukov, V. S. Vliyanie elektrolitnogo balansa na korov [Tekst] / V. S. Kryukov // GK AgroBalt trejd, Sankt-Peterburg. - 2011. - s. 8-12.

8. Mikko, A. Pravil'noe kormlenie kormlenie do i posle otela [Tekst] / A. Mikko., O. V. Ovchinnikova // ZHivotnovodstvo Rossii. - Mart, 2012. - S. 38-39.

9. Matveeva A.V. Osobennostigematologicheskogo profilya krupnogo rogatogo skota v usloviyah stressa, vyzvannogo patologicheskimi processami v oblasti distal'nogo otdela konechnostej [Tekst] / A.V. Matveeva, E.O. Sajthanov // Materialy Nacional'noj nauchno-prakticheskoj konferencii "Prioritetnye napravleniya nauchno-tekhnologicheskogo razvitiya agropromyshlennogo kompleksa Rossii». - Ryazan': RGATU. 2019. S. 193-199.

10. Zaharov, V.A. Nauchnoe soprovozhdenie effektivnogo vedeniya vosproizvodstva krupnogo rogatogo skota [Tekst] / V.A. Zaharov, O.V. Bakovekaya, E.V. Kiseleva // APK dostizheniya nauki i tekhniki. - 2015. -No $3-$ S. $51-54$.

11. Redkozubova, V. I. Profilaktika gipokal'ciemii u korov [Tekst] / V. I. Redkozubova // ZHivotnovodstvo Rossii. Tematicheskij vypusk. - 2018 god. - S. 58-60.

12. Sajthanov, E.O. Izuchenie chastoty registracii $i$ haraktera patologii kopytec $v$ zhivotnovodcheskom hozyajstve s besprivyaznym soderzhaniem [Tekst] / E.O. Sajthanov, D.S. Besedin, A.V. Rudnaya // Vestnik RGATU, № 3, 2018. - S.62-67.

13. Susanna Tauriajnen Kationno-anionnyj balans $v$ kormah i potreblenie kal'ciya i magniya $u$ stel'nyh korov [Tekst] / S. Tauriajnen S. // Hel'sinkskij universitet Kafedra zhivotnovodstva. - 2001. - S. 48-52.

14. Mecitoglu, Z. Prepartum urine $\mathrm{pH}$ as a predictor of left displacement of abomasum / Z. Mecitoglu, S. Senturk, C. Kara, G. Akgul, E. Uzabacı // The Journal of Animal \& Plant Sciences, 26(2): 2016, Page: 320-324.

15. Gelfert, A. Impact of a prolonged period of feeding anionic saltson the acid-base-balance and calcium metabolism ofdairy cows / A.Löptien, S-S.Gelfert, A. N. Montag, W. Baumgartner, R. Staufenbiel // Vet. Med. Austria,Wien. Tierärztl. Mschr. 93 (2006), 304 - 310 - https://www.researchgate.net/publication/289048835 Impact_of_a_prolonged_period_of_feeding_anionic_salts_on_the_acid-base-balance_and_calcium_ metabolism_of_dairy_cows/

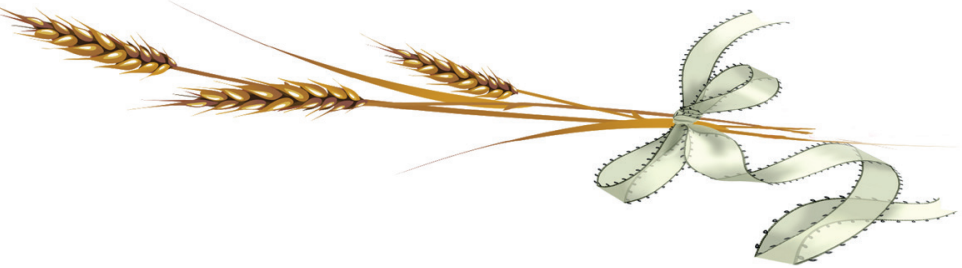

УДК 631.82:631.58:638.132

DOI 10.36508/RSATU.2020.45.1.005

\section{ВЛИЯНИЕ МИНЕРАЛЬНОГО ПИТАНИЯ НА МЕДОВУЮ ПРОДУКТИВНОСТЬ МОРДОВНИКА ШАРОГОЛОВОГО (ЕCHINOPS SPHAEROCEPHALUS L.)}

ДОКУКИн Юрий Викторович, канд. с.-х. наук, ведущий научный compyдник, rybnoebee@mail.ru ФГБНУ «ФНЦ пчеловодства»

Echinops sphaerocephalus - многолетнее растение семейства астровых, может применяться в качестве нектароносного, лекарственного, противоэрозионного и декоративного растения. Регулирование минерального питания способствует повышению продуктивности растений. Внесение минеральных удобрений является одним из действенных способов увеличения продуктивности растений. Цель исследований - изучить влияние разных норм минеральных удобрений на медовую продуктивность мордовника шароголового в интересах пчеловодства. Медовую продуктивность определяли по содержанию сахаров в нектаре цветков методом смывания и последующим анализом по Гагендорн-Иенсена. Содержание сахаров пересчитывали на гектар и умножали на коэффрициент

(С Докукин Ю. В., 2020 г. 
1,25. Математическую обработку результатов проводили методом дисперсионного анализа с использованием компьютерной программы Ехсеl 2010. Одним из показателей развития растительного сообщества является густота стояния растений. Влияние минеральных удобрений должно быть направлено на фрормирование как можно большего числа генеративных побегов. Мордовник шароголовый начинает их формировать на второй год жизни. Исследования показывают, что данный показатель в этот период в десятки раз меньще по сравнению с третьим годом жизни. На третий-четвертый годы жизни (2017-2018 гг.) количество генеративных побегов наибольшее по сравнению с другими годами наблюдений. Ежегодная подкормка азотными удобрениями приводит к существенному возрастанию этого показателя. Мордовник шароголовый отзывчив на внесение азотных удобрений. Наблюдается прямая положительная корреляция между количеством иветков на единице площади и медовой продуктивностью посевов: коэфрфициент корреляции 0,993, коэфрфициент детерминации 0,988. Главные выводы: наилучшие показатели получены при внесении $N_{30} P_{80} K_{80}$ в год посева и $\mathrm{N}_{90}$ в ежегодную подкормку весной. По количеству генеративных побегов этот вариант превосходит контроль на 88,9\%, а по количеству цветков и медовой продуктивности - в 3 раза. В то же время в первые три года возможно внесение $N_{60}$ и только на четвертый год необходимо увеличить дозу до $N_{90}$.

Ключевые слова: мордовник шароголовый, медовая продуктивность, минеральные удобрения, количество цветков, генеративные побеги.

\section{Введение}

В повышении рентабельности пасек с медоносными пчелами важное значение имеет создание цветочно-нектароносного конвейера из растений, способных обеспечивать пчел высоким медосбором. Среди растительных видов заслуживает внимания мордовник шароголовый (Echinops sphaerocephalus L.). Это высокое многолетнее pacтение семейства астровых может использоваться в нескольких направлениях: в пчеловодстве, фрармакологии и цветоводстве.

Мордовник шароголовый занимает значительную площадь на территории нашей страны. Он рассеянно растет в естественных растительных ассоциациях, на заброшенных полях. Мощная корневая система препятствует смыву почв на эрозионных землях.

Голубые цветки образуют шарообразные головки, которые эффректно смотрятся на фоне поля. Плоды - шероховатые односемянки с плотной оболочкой. Масса 1000 плодов составляет 15-16 г.

Мордовник шароголовый в условиях Центра России начинает цвести в конце июля и цветет в зависимости от погодных условий 30-40 дней. На одном соцветии может одновременно работать несколько пчел. Вегетационный период длится около 180 дней. Учитывая, что в этот период в центре России отцветают основные нектароносные растения, Echinops sphaerocephalus способствует продлению медосборного периода и повышению рентабельности пасек.

Он является важным видом в системе цветочно-нектароносного конвейера в условиях Центрального федерального округа.

В литературных источниках можно встретить разные данные о медовой продуктивности мордовника шароголового: от 1,6 до 10 ц/га [1, 3, 5]. Такой разброс данных связан с тем, что в естественных условиях он имеет низкую плотность и различные условия произрастания. Искусственные фритоценозы обладают в несколько раз большей продуктивностью по сравнению с естественными популяциями.

Необходимым условием введения мордовника шароголового в культуру является исследование агротехнических приемов его возделывания. Peгулирование минерального питания способствует повышению медовой продуктивности растений. Внесение минеральных удобрений является одним из действенных способов увеличения этого показателя.

Цель исследований - изучить влияние разных норм минеральных удобрений на медовую продуктивность мордовника шароголового в интересах пчеловодства.

Объекты и методы исследований

В 2015 г. был заложен опыт в Рыбновском районе Рязанской области согласно методическим рекомендациям, принятым в растениеводстве $[4,7]$. Размещение делянок систематическое. Повторность четырехкратная. Площадь опытных делянок $30 \mathrm{~m}^{2}$.

Почва серая лесная тяжелосуглинистая, содержание гумуса 2,8\%, подвижного фоосфора 85,4 , калия -90 мг/кг почвы, $\mathrm{pH}-5,2$.

Схема опыта:

1) без удобрений (контроль);

2) фоон;

3)

4) фоOH $^{+\mathrm{N}_{60}}$;

5) $\mathrm{\phi OH}+\mathrm{N}_{90}^{60}$.

Под предпосевную обработку почвы в вариантах 2-5 вносили $\mathrm{N}_{30} \mathrm{P}_{80} \mathrm{~K}_{80}$ (фон). В последующие годы в вариантах 3-5 в качестве подкормке весной вносились разные нормы азотных удобрений, а фон не вносился.

Медовую продуктивность определяли по содержанию сахаров в нектаре цветков методом смывания и анализом по Гагендорну-Иенсену. Содержание сахаров пересчитывали на гектар и умножали на коэфффициент 1,25 [2]. Математическую обработку результатов проводили методом дисперсионного анализа с использованием компьютерной программы Excel 2010.

\section{Результаты исследований}

Высота растений является важным фактором, определяющим развитие популяции (табл. 1). В первые два года использования посевов (2016- 
2017 гг.) значимое воздействие на этот показатель оказывают $\mathrm{N}_{60}$ и $\mathrm{N}_{90}$. В последующие годы из-за ослабления особей в популяции растения мордовника шароголового начинают положительно реагировать и на более низкие дозы азота.

В среднем за все годы наблюдений внесение азотных удобрений в подкормку увеличивает данный показатель по сравнению сконтролем на 8,4-21,2\%.

Таблица 1 - Высота растений (см) мордовника шароголового в зависимости от минеральных удобрений

\begin{tabular}{|c|c|c|c|c|c|}
\hline \multirow{2}{*}{ Вариант } & \multicolumn{3}{|c|}{ Годы } & \multirow{2}{*}{ Среднее } \\
\cline { 2 - 5 } & 2016 & 2017 & 2018 & 2019 & \\
\hline Без удобрений & $129,2 \pm 2,39$ & $145,2 \pm 3,49$ & $121,6 \pm 3,12$ & $88,1 \pm 2,73$ & $121,0 \pm 1,48$ \\
\hline Фон & $127,5 \pm 5,29$ & $145,6 \pm 3,74$ & $127,0 \pm 3,49$ & $91,6 \pm 3,33$ & $122,9 \pm 2,02$ \\
\hline Фон $+\mathrm{N}_{30}$ & $131,0 \pm 1,76$ & $153,8 \pm 3,22$ & $137,8 \pm 3,06$ & $102,2 \pm 2,64$ & $131,2 \pm 1,36$ \\
\hline Фон $+\mathrm{N}_{60}$ & $137,5 \pm 2,86$ & $157,9 \pm 3,41$ & $143,4 \pm 2,36$ & $115,4 \pm 2,62$ & $138,6 \pm 1,42$ \\
\hline Фон $+\mathrm{N}_{90}$ & $141,6 \pm 1,80$ & $168,5 \pm 2,57$ & $150,7 \pm 1,74$ & $125,6 \pm 3,51$ & $146,6 \pm 1,25$ \\
\hline
\end{tabular}

Одним из показателей развития растительного сообщества является густота стояния растений. Влияние минеральных удобрений должно быть направлено на формирование как можно большего числа генеративных побегов [6].

Мордовник шароголовый начинает их формировать на второй год жизни. Исследования показывают, что данный показатель в этот период очень мал (табл. 2).

Таблица 2 - Количество генеративных побегов мордовника шароголового в зависимости от минеральных удобрений, шт./м²

\begin{tabular}{|c|c|c|c|c|c|}
\hline \multirow{2}{*}{ Вариант } & \multicolumn{4}{|c|}{ Годы } & \multirow{2}{*}{ Среднее } \\
\hline & 2016 & 2017 & 2018 & 2019 & \\
\hline Без удобрений & 0,3 & 10,2 & 11,8 & 6,5 & 7,2 \\
\hline Фон & 0,2 & 12,2 & 13,0 & 7,8 & 8,3 \\
\hline$\Phi \mathrm{OH}+\mathrm{N}_{30}$ & 0,4 & 16,0 & 16,5 & 11,5 & 11,1 \\
\hline$\Phi \mathrm{OH}+\mathrm{N}_{60}$ & 1,2 & 18,0 & 19,5 & 13,0 & 12,9 \\
\hline$\Phi \mathrm{OH}+\mathrm{N}_{90}$ & 1,0 & 18,5 & 20,2 & 14,5 & 13,6 \\
\hline $\mathrm{HCP}_{05}$ & 0,3 & 5,3 & 3,8 & 2,5 & 2,1 \\
\hline
\end{tabular}

На третий-четвертый годы жизни (2017-2018 гг.) количество генеративных побегов наибольшее по сравнению с другими годами наблюдений. Ежегодная подкормка азотными удобрениями приводит к существенному возрастанию этого показателя. На пятый год жизни количество генеративных побегов снижается на 28,2-44,9\%. Причем наибольшее относительное снижение наблюдается в варианте без удобрений.
В среднем за все годы исследований внесение $\mathrm{N}_{60}$ и $\mathrm{N}_{90}$ приводит к увеличению этого показателя на 79,2-88,9\% по сравнению с контролем.

Количество цветков на единице площади зависит как от количества цветков на побеге, так и от количества этих побегов. Причем второй показатель в нашем опыте оказывает большее влияние, в результате чего в 2016 г. образовывалось мало цветков на м² (табл. 3).

Таблица 3 - Количество цветков мордовника шароголового в зависимости от минеральных удобрений, тыс. шт./м²

\begin{tabular}{|c|c|c|c|c|c|}
\hline \multirow{2}{*}{ Вариант } & \multicolumn{4}{|c|}{ Годы } & \multirow{2}{*}{ Среднеє } \\
\hline & 2016 & 2017 & 2018 & 2019 & \\
\hline Без удобрений & 0,4 & 9,9 & 14,5 & 3,5 & 7,1 \\
\hline Фон & 0,3 & 15,2 & 18,2 & 5,7 & 9,9 \\
\hline$\Phi \mathrm{OH}+\mathrm{N}_{30}$ & 0,5 & 19,1 & 23,2 & 10,8 & 13,4 \\
\hline$\Phi \mathrm{OH}+\mathrm{N}_{60}$ & 1,2 & 24,0 & 27,7 & 11,1 & 16,0 \\
\hline$\Phi \mathrm{OH}+\mathrm{N}_{90}$ & 1,7 & 30,7 & 30,6 & 21,3 & 21,1 \\
\hline $\mathrm{HCP}_{05}$ & 0,4 & 6,8 & 5,4 & 2,6 & 2,7 \\
\hline
\end{tabular}

Последствия фоона не сказываются на этом показателе. Наибольшее количество цветков на единице площади достигается на третий-четвертый годы жизни.
На пятый год происходит уменьшение данного показателя за счет выпадения растений, переходу посевов в состояние естественных популяций. Количество цветков на единице площади в 2019 г. 
уменьшается по сравнению с 2018 г. в 1,4-4,1 раза в зависимости от варианта. Внесение азотных удобрений тормозит этот процесс.

Анализируя данный показатель, в среднем за все годы, можно сделать вывод, что внесение азотных удобрений оказывает положительный эффект на количество цветков. Максимальный показатель получен при внесении $\mathrm{N}_{90}$

Медовая продуктивность растительных сообществ фоормируется как за счет количества цветков, так и за счет выделения нектара в цветках. Влияние минеральных веществ может действовать в двух направлениях: число цветков и выделение сахаров в нектаре. В наших исследованиях первый фактор является определяющим из-за его большей пластичности к агротехнике возделывания. Выделение нектара - сложный фризиологический процесс, на который оказывают влияние большое количество факторов.

Существует линейная корреляция между количеством цветков на единице площади и медовой продуктивностью. Коэффрициент корреляции равен 0,993, коэффицциент детерминации составляет 0,988, то есть медовая продуктивность в 98,8\% случаев зависит от количества цветков на единице площади. Зависимость характеризуется как сильная (рис. 1). Уравнение регрессии имеет вид
$Y=10,19 x-9,8497$

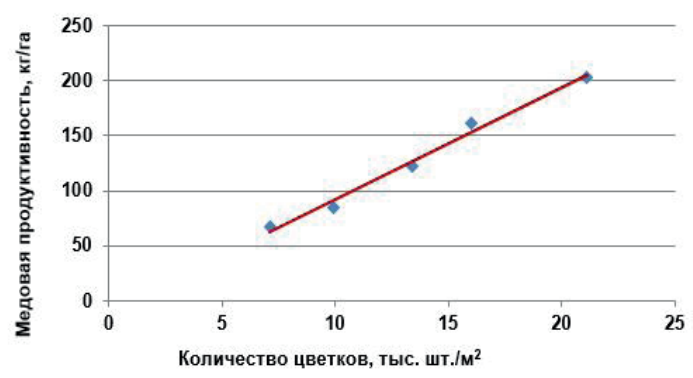

Рис. 1 - Точечный график и теоретическая линия регрессии между количеством цветков и медовой продуктивностью при прямолинейной корреляции

Внесение полного минерального удобрения в качестве фона в первый год под посев не оказывает существенного влияния на медовую продуктивность в последующие годы (табл. 4).

Особенно эфффективно в первые три года использования посевов внесение $\mathrm{N}_{60}$ в подкормку весной, на четвертый год - $\mathrm{N}_{90}$, что связано со старением плантаций, более высокие дозы азота стимулируют развитие цветков

\section{Таблица 4 - Медовая продуктивность мордовника шароголового в зависимости} от минеральных удобрений, кг/га

\begin{tabular}{|c|c|c|c|c|c|}
\hline \multirow{2}{*}{ Вариант } & \multicolumn{4}{|c|}{ Годы } & \multirow{2}{*}{ Среднее } \\
\hline & 2016 & 2017 & 2018 & 2019 & \\
\hline Без удобрений & 2,0 & 157,1 & 95,7 & 15,8 & 67,7 \\
\hline$\Phi \mathrm{OH}$ & 1,8 & 162,4 & 126,8 & 45,4 & 84,1 \\
\hline$\Phi \mathrm{OH}+\mathrm{N}_{30}$ & 3,0 & 179,7 & 202,8 & 103,6 & 122,3 \\
\hline$\Phi \mathrm{OH}+\mathrm{N}_{60}$ & 8,6 & 262,4 & 269,9 & 102,3 & 160,8 \\
\hline$\Phi \mathrm{OH}+\mathrm{N}_{90}$ & 10,5 & 285,6 & 289,4 & 229,2 & 203,7 \\
\hline $\mathrm{HCP}_{05}$ & 2,8 & 71,8 & 48,5 & 26,7 & 26,0 \\
\hline
\end{tabular}

В среднем за годы наблюдений медовая продуктивность возрастает при внесении минеральных удобрений в 1,2-3,0 раза по сравнению с контролем в зависимости от варианта.

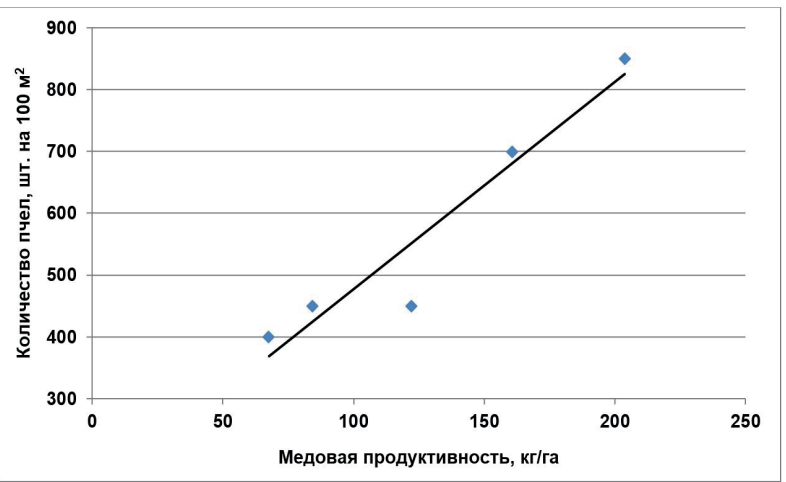

Рис. 2 - Точечный график и теоретическая линия регрессии при прямолинейной корреляции между медовой продуктивностью и количеством пчел
Наблюдается прямая корреляционная зависимость количества медоносных пчел от медовой продуктивности посевов (рис. 2). Коэффрициент корреляции $r=0,96 \pm 0,17$, коэфффициент детерминации - 0,91. Уравнение регрессии можно описать формулой $\mathrm{Y}=3,36 \mathrm{X}+140,93$.

\section{Заключение}

Исследования показали, что мордовник шароголовый отзывчив на внесение азотных удобрений. Наилучшие показатели получены при внесении $\mathrm{N}_{30} \mathrm{P}_{80} \mathrm{~K}_{80}$ в год посева и $\mathrm{N}_{90}$ в ежегодную подкормку весной. По количеству генеративных побегов этот вариант превосходит контроль на $88,9 \%$, а по количеству цветков и медовой продуктивности - в 3 раза. В то же время в первые три года возможно внесение $\mathrm{N}_{60}$ и только на четвертый год необходимо увеличить дозу до $\mathrm{N}_{90}$.

\section{Список литературы}

1. Абакарова, М. А. О видовом разнообразии медоносных растений равнинного Дагестана [Текст] / М. А. Абакарова, Т. А. Алиев // Труды ин- 
ститута геологии Дагестанского научного центра. - 2015. - № 65. - С.161-167.

2. Бурмистров, А. Н. Учет медоносных ресурсов и оценка нектарной и пыльцевой продуктивности растений [Текст] / А. Н. Бурмистров, И. М. Ишемгулов. - М.: Российская академия сельскохозяйственных наук, НИИ пчеловодства, 2001. - 25 с.

3. Глухов, М. М. Медоносные растения [Текст] / М. М. Глухов. - М. : Колос, 1974. - 304 с.

4. Докукин, Ю. В. Агротехнические приемы успешного возделывания мордовника шароголового [Текст] /Ю.В. Докукин, А.П. Савин // Пчеловодство. - 2019. - № 7. - С.24-25.

5. Докукин, Ю. В. Влияние способа сева и нор- мы высева на нектарную продуктивность мордовника шароголового [Текст] /Ю.В. Докукин // Вестник РГАТУ. - 2018. - № 1. - С.19-21.

6. Докукин, Ю. В. Создание высокопродуктивных агрофитоценозов медоносно-кормового использования из козлятника восточного и свербиги восточной [Текст]: диссертация ... канд. с.-х. наук: 06.01.09: / Юрий Викторович Докукин. - Рыбное: НИИ пчеловодства, 2007. - 197 с.

7. Доспехов, Б. А. Методика полевого опыта: (с основами статистической обработки результатов исследований) [Текст]. - изд. 4-е, перераб. и доп. / Б.А. Доспехов. - М.: Колос, 1979. - 416 с.

\title{
INFLUENCE OF MINERAL NUTRITION ON HONEY PRODUCTIVITY OF ECHINOPS SPHAEROCEPHALUS
}

\author{
Dokukin Yuri V., candidate of agricultural Sciences, Leading Researche, rybnoebee@mail.ru \\ FSBSI "FSC of Beekeeping"
}

Echinops sphaerocephalus is a perennial plant of the Asteraceae family. It can be used as a nectariferous, medicinal, anti-erosion and decorative plant. The regulation of mineral nutrition helps to increase the productivity of plants. Applying mineral fertilizers is one of the most effective ways to increase plant productivity. The purpose of the research is to study the effect of different norms of mineral fertilizers on the honey productivity of the Echinops sphaerocephalus in the interests of beekeeping. Honey productivity was determined by the sugar content in the nectar of flowers by the method of rinsing and subsequent analysis by Gagendorn-Jensen of St. Petersburg. The sugar content was recalculated per hectare and multiplied by a coefficient of 1.25. Mathematical processing of the results was carried out by the method of variance analysis using the Excel 2010 computer program. One of the indicators of the development of the plant community is the density of plant standing. The influence of mineral fertilizers should be directed to the formation of as many generative shoots as possible. Echinops cue ball begins to form in the second year of life. Research shows that this indicator in this period is ten times smaller than in the third year of life. In the third and fourth years of life (2017-2018), the number of generative shoots is the highest compared to other years of observation. Annual fertilizing with nitrogen fertilizers leads to a significant increase in this indicator. Echinops sphaerocephalus is responsive to the application of nitrogen fertilizers. There is a direct positive correlation between the number of flowers per unit area and the honey productivity of crops, the correlation coefficient is 0.993, the determination coefficient is 0.988. Main conclusions: the best results were obtained when adding $N_{30} P_{80} K_{80}$ in the year of sowing and $N_{90}$ in the annual feeding in the spring. By the number of generative shoots, this variant exceeds the control by $88.9 \%$, and by the number of flowers and honey productivity - by 3 times. At the same time, $N_{60}$ can be added in the first three years, and only in the fourth year it is necessary to increase the dose to $N_{90}$.

Key words: Echinops sphaerocephalus, honey productivity, mineral fertilizers, number of flowers, generative shoots.

1. Abakarova, M.A. O vidovom raznoobrazii medonosnykh rastenij ravninnogo dagestana [tekst] / M.A. Abakarova, T.A. Aliev // Trudy instituta geologii dagestanskogo nauchnogo tsentra. - 2015. - 65. - s.161-167.

2 Burmistrov, A.N. Uchet medonosnykh resursov $i$ otsenka nektarnoj i pyltsevoj produktivnosti rastenij [tekst] /A.N. Burmistrov, i.m. ishemgulov. - M.: Rossijskaya akademiya selskokhozyajstvennykh nauk, NII pchelovodstva, 2001. - 25 s.

3 Glukhov, M.M. Medonosnye rasteniya [tekst] / M.M. Glukhov. - M.: Kolos, 1974. - 304 s.

4 Dokukin, Yu. V. Agrotehnizeskie priemi uspeschnogo wosdelivaniia mordovnika scharogolovogo / Yu. V. Dokukin, A.P. Savin [tekst] / Pselovodstvo/ - 2019/ - 7. - s. 24-25.

5 Dokukin, Yu. V Vliya nie sposoba sewa ni normia vaiseva na nektarnuiu produktivnost / [tekst] / Yu. V. Dokukin // Vestnik Ryazanskogo gosudarstvennogo Universiteta im P.A. Kostycheva. 201 8. - 1. - P.19-21.

6. Dokukin, Yu. V Sosdanie visokoproduktiwnix agrofitozenosov medonosno-kormowogo ispolsowaniia is koslatnika vostoznogo I sverbigi vostoznoiy / dissertaziia na soiskaniia uzenoi stepeni kandidata s.-h. nauk. Rijbnoe: NII pzelovodstva, 207. - $197 \mathrm{~s}$.

7 Dospekhov, B.A. Metodika polevogo opyta: (s osnovami statisticheskoj obrabotki rezultatov issledovanij) - izd. 4-e, pererab. i dop. [tekst] / B.A. Dospekhov. - M.: Kolos, 1979. - 416 s. 


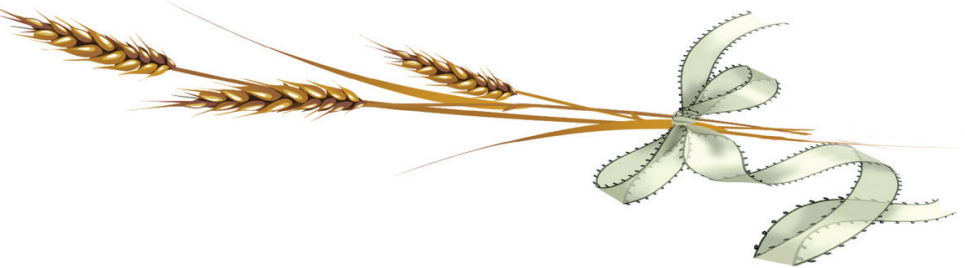

УДК 631.4 (571.621)

DOI 10.36508/RSATU.2020.45.1.006

\section{ВЛИЯНИЕ ОСУШЕНИЯ НА ИЗМЕНЕНИЕ АГРОХИМИЧЕСКИХ СВОЙСТВ ЛУГОВО-ГЛЕЕВЫХ ПОЧВ СРЕДНЕАМУРСКОЙ НИЗМЕННОСТИ}

ЗУБАРЕВ Виталий Александрович, научный сотрудник, ФГБУН Институт комплексного анализа региональных проблем ДВО РАН, Zubarev_1986@mail.ru

МАЖАЙСКИЙ Юрий Анатольевич, д-р с.-х. наук, профрессор, Генеральный директор ООО "МНТЦ", главный научный сотрудник Мещерского фрилиала ФГБНУ «ВНИИГиМ им. А.Н. Костякова», mail@ mntc.pro

Целью исследования являлось выяснение и уточнение характера и степени изменения основных свойств сельскохозяйственных лугово-глеевых почв под влиянием осушительной мелиорации. Для изучения влияния осушительной мелиорации на состояние почв на территории Среднеамурской низменности полевые исследования проводились в 2008 и через десять лент в 2018 г2. Для сравнительного анализа выбраны неосушенные и осушенные, используемые в сельскохозяйственном обороте, лугово-глеевые почвы первой надпойменной террасы речной долины р. Амур. В каждом исследуемом полигоне производился отбор проб из поверхностного почвенного горизонта (0-20 см) методом квадрата. Все агрохимические анализы проводили с использованием общепринятых методов. Проведение осушительной мелиорации на тяжелых лугово-глеевых почвах Среднеамурской низменности (на примере Еврейской автономной области) сопровождается изменением рН в нейтральную сторону и небольшим увеличением валового содержания металлов, поглощенных оснований и степени насыщенности основаниями. Снижение содержания гумуса связано с усилением аэрации при ежегодной распашке земель, сменой водного режима на застойно-промывной, что способствует быстрой сработке гумуса. Длительное осушение почв приводит не к усилению минерализации органического вещества, а к качественному изменению его состава, что выражается в повышении в пахотном слое отношения содержания уәлерода гуминовых кислот к содержанию уәлерода фрульвокислот. Осушительная мелиорация без дальнейшего окультуривания отрицательно влияет на плодородие почв, ухудшая их агрохимические, фризические и другие свойства, поэтому иелесообразно возобновить внесение органических и минеральных удобрений, а также проводить известкование на мелиорируемых почвах.

Ключевые слова: Среднеамурская низменность, лугово-глеевые почвы, гумус, приграничный район, осушительная мелиорация.

\section{Введение}

Одним из основных компонентов наземной экосистемы, которая обеспечивает стабильное существование биосферы, является почва. Характерной чертой современного земледелия, по результатам большого количества исследований, является трансформация и дальнейшая деградация вовлеченных в сельскохозяйственное использование почв. Проблема деградации сельскохозяйственных земель понимается и на государственном уровне, вследствие чего правительство РФ опубликовало постановление от 28 ноября 2002 года № 846 «Об утверждении Положения об осуществлении государственного мониторинга земель» [1]. В данном постановлении была разработана программа развития сельского хозяйства, где важное место занимает проблема повышения плодородия и качество пахотных почв. Повышение качества почв и их плодородие планировалось повысить путем применения современной агротехники, мелиорации земель и химизации, а также обязательного внедрения достижений научно-технического прогресса [2].
На территории Еврейской автономной области (EAO) частое переувлажнение является фрактором, ограничивающим получение стабильных и высоких урожаев [3]. Проблема экологической защиты земель, в особенности подверженных влиянию осушения, в наше время наиболее актуальна и является одним из наиболее приоритетных вопросов охраны природной среды и мест обитания человека $[4,5]$. Интерес к подобным исследованиям вызван территориальной близостью Китая к ЕАО. На территории ЕАО по ряду причин практически отсутствует контроль за экологическим и агрохимическим состоянием арендуемых сельскохозяйственных земель. За последнее время масштабы использования пахотных почв приграничных районов ЕАО китайскими арендаторами увеличиваются, для них характерно интенсивное применение большого количества разнообразных удобрений и пестицидов [6].

По мнению В.А.Ковды и Б.Г.Розанова, осушение должно учитывать не только экономические потребности региона, но и то, что и в будущем естественная среда будет устойчиво улучшаться

() Зубарев В. А., Мажайский Ю. А., 2020 г. 
[7]. Актуальность выбранной темы обусловлена тем, что для разработки совершенных мелиоративных систем необходимо получить разнообразные данные о положительных и отрицательных изменениях, происходящих в почвах под влиянием осушения.

Целью работы является анализ уровня агрохимического изменения основных свойств пахотных лугово-глеевых почв ЕАО под влиянием осушительной мелиорации.

\section{Материалы и методики исследования}

Район исследований (рис. ), расположенный на юго-западе EAO, представляет собой крупную межгорную впадину сложного строения, образованную озерно-аллювиальными, песчано-суглинистыми толщами среднего и верхнего плей- стоцена. По климатическому районированию территория исследования относится к муссонной лесной климатической области умеренных широт, среднегодовая сумма осадков - 500-600 мм, в отдельные годы до 1000 мм. Большое количество летних осадков (40-50\% годовой суммы осадков) выпадает в июле-августе и создает условия временного избыточного поверхностного увлажнения почв [8].

Сложные природно-климатические условия региона, такие как тяжелый гранулометрический состав почв, частое избыточное поверхностное увлажнение, неустойчивая верховодка, периодически изменяющиеся окислительно-восстановительные условия - определяют процессы фоормирования почв и их специфические черты.
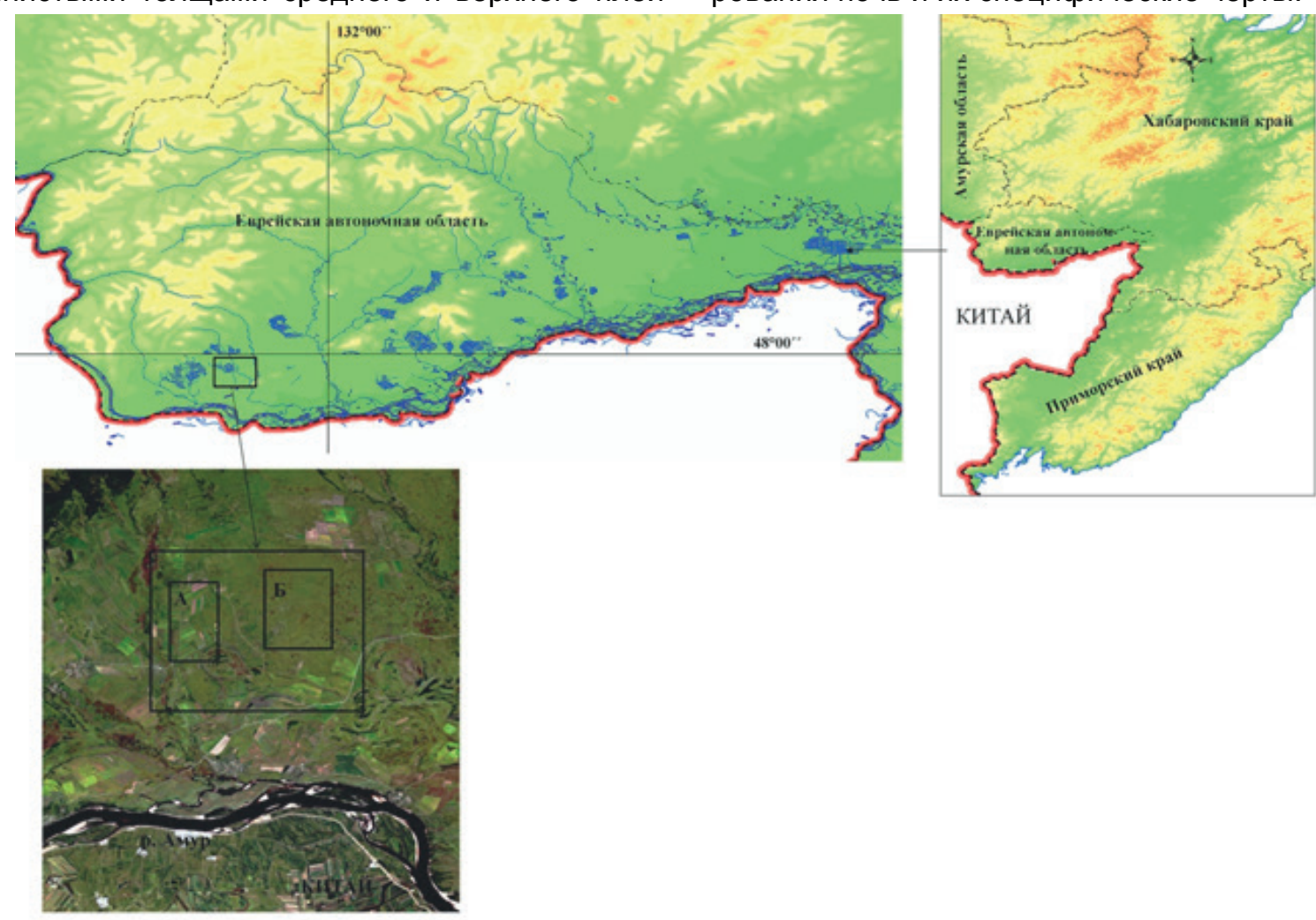

Рис. - Расположение района исследования

Объектом исследования послужили осушенные и не осушенные луговые дерново-глеевые почвы поймы р. Амур в юго-западной части Еврейской автономной области. Гумусово-аккумулятивный горизонт имеет мощность 10-15 см. В верхней части горизонт плотно задернован корнями луговой растительности, нижняя граница горизонта неровная, что характерно для луговых почв низменности. Реакция среды кислая. Эти почвы устойчивы к водной эрозии. При освоении требуют осушения глубоким дренажем и длительного окультуривания пахотного горизонта. На луговые дерново-глеевые почвы приходится наибольшая доля почвенного фонда равнинной части ЕАО, равная 483 тыс. га. По механическому составу большинство почв относится к тяжелым и средним суглинкам. Гранулометрический состав почв средне- и тяжелосуглинистый, что является основ- ной причиной их переувлажнения при обильном выпадении летних осадков. Плотность сложения

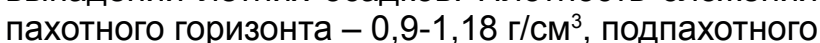

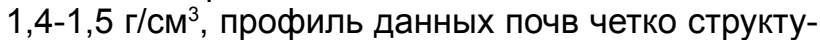
рирован. Водоустойчивость почвенных агрегатов в пахотном слое высокая - 80-90\%, в иллювиальном горизонте она неустойчива и варьирует в пределах $10-75 \%$. Это ухудшает условия питания растений и затрудняет проведение агротехнических работ [9]. Почвы фрормируется на практически водонепроницаемой озерно-аллювиальной глине средне-позднеплейстоценового возраста под разнотравно-осоково-вейниковым лугом с кочковатым микрорельефом. Эднфикаторную роль в травянистой растительности играют такие виды, как вейник Лангсдорфа (Calamagrostis Langsdorfii), мятлик луговой (Poa prateasis), овсяница красная (Festuca rubra), осока Шмидта (Carex schmidtii), пу- 
шица многоколосковая (Eriophorum polystachyит). Увлажнение атмосферное, для профиля характерно периодическое поверхностное переувлажнение

Для изучения влияния осушительной мелиорации на состояние почв на территории Среднеамурской низменности полевые исследования проводились в 2008 и через десять лент в 2018 гг. Для сравнительного анализа выбраны немелиорированные и мелиорированные, используемые в сельскохозяйственном обороте, лугово-глеевые почвы первой надпойменной террасы речной долины р. Амур. В каждом исследуемом полигоне производился отбор проб из поверхностного почвенного горизонта (0-25 cм) методом квадрата по ГОСТ 28168-89. Общее число всех проб за исследуемый период - 340 (170 образцов почв не мелиорированных и 170 - мелиорированных).

Агрохимические анализы проводили с использованием общепринятых методов: кислотность солевой вытяжки $\mathrm{pH}_{\mathrm{Kcl}}$ - потенциометрически (ГОСТ 26483- 85), гумус - по методу Тюрина в модификации ЦИНАО (ГОСТ 26213-91), подвижный фросфрор - в вытяжке 0,2 $\mathrm{HCl}$ по Кирсанову в модификации ЦИНАО (ГОСТ 26207-91), сумма поглощенных оснований - по методу Каппена (ГОСТ 27821-88). Групповой состав гумуса определен ускоренным методом Кононовой М.И., Бельчиковой Н. с применением пирофосфата натрия (Агрохимические..., 1975). Валовой химический состав почв определен по методике, описанной Е.В.Аринушкиной (1970).

\section{Результаты и их обсуждение}

Влияние осушительной мелиорации на изменение свойств почвы разнообразно и часто противоречиво. Исследования многих ученых показывают, что на осушенных почвах создаются условия, более благоприятные для развития растений, чем на неосушенных (С.Г. Скоропанов, 1958; Ц.Н. Шкинкис, 1977; Л.П. Кареле, 1976; В. Миляускас, 1963; Е.П. Панов и другие, 1978, 1981).

Нами показано, что (в 2008 г.) поверхностные плодородные горизонты осушенных почв (0-20 см) содержали больше гумуса (на 0,1\%), чем немелиорированные (табл.1), что явно связано с проведением агротехнических работ, а также с внесением органических и минеральных удобрений на осушаемые поля в предыдущие годы. В 2018 г. на неосушенных почвах произошло увеличение содержания гумуса на $40 \%$, а на осушенных всего на $19 \%$. За десятилетний период, к 2018 г., в неосушенных почвах произошло увеличение содержание гумуса на 40\%, что связано с периодическими весенними и летне-осенними паводками в исследуемой части Среднеамурской низменности в 2010, 2013, 2014, 2017 гг. В период паводков на поверхности почвы откладывался наилок мощностью 0,5-1,0 см. Таким образом, за 10 лет на поверхности почвы могло отложиться не менее 5-10 см аллювия, содержащего органическое вещество. В осушенных почвах, к 2018г., увеличение содержания гумуса произошло всего на 19\%, поступающий наилок ежегодно перемешивается с пахотным горизонтом, как бы разбавляя его и понижая тем самым общее количество органического вещества в поверхностном слое. Снижение гумуса может быть также связано с аэрацией при ежегодной распашке и со сменой застойного водного режима на застойно-промывной, с частой сменой анаэробных и аэробных условий, способствующей быстрой сработке.

Таблица 1 - Агрохимическое состояние луговых глеевых глинистых почв при длительном сельскохозяйственном использовании

\begin{tabular}{|l|c|c|c|c|c|}
\hline $\begin{array}{c}\text { Полигоны отбо- } \\
\text { ра проб почв }\end{array}$ & $\begin{array}{c}\text { Гумус } \\
\%\end{array}$ & $\mathrm{pHH}_{20}$ & $\mathrm{pH}_{\text {ксІ }}$ & $\begin{array}{c}\text { Сумма погло- } \\
\text { щенных осно- } \\
\text { ваний }\end{array}$ & $\begin{array}{c}\text { Степень } \\
\text { насыщенности, } \\
\%\end{array}$ \\
\hline неосушенные & $\frac{3,13}{4,41}$ & $\frac{5,30}{5,70}$ & $\frac{4,30}{4,45}$ & $\frac{29,90}{26,30}$ & $\frac{72}{87}$ \\
\hline осушенные & $\underline{3,22}$ & $\frac{7,13}{7,10}$ & $\underline{4,89}$ & $\underline{38,50}$ & $\underline{46}$ \\
\hline
\end{tabular}

Примечание: числитель - 2008 год, знаменатель - 2018 год

Неосушенные почвы характеризуются как кислые и слабокислые, однако при мелиорировании и прокладке дренажа изменяются кислородные условия, в них отмечено увеличение кислотности и количества подвижного алюминия, содержания поглощенных оснований и степени насыщенности основаниями.

Групповой состав гумуса отражает генетические особенности и условия формирования почв и служит признаком, позволяющим судить о степени преобразованности сельскохозяйственных почв [10]. При изучении воздействия влияния осушения было выяснено, что данные группового состава гумуса (табл. 2) свидетельствуют об изменении гумусового состояния почв при сельскохозяйственном использовании и осушении по сравнению с аналогичными данными 2008 года.

Таблица 2 - Групповой состав гумуса луговых глеевых почв

\begin{tabular}{|c|c|c|c|c|}
\hline \multirow{2}{*}{$\begin{array}{c}\text { Полигоны отбора } \\
\text { проб почв }\end{array}$} & $\begin{array}{c}\text { Гуминовые } \\
\text { кислоты }\end{array}$ & Фульвокислоты & $\begin{array}{c}\text { Негидролизуемый } \\
\text { остаток }\end{array}$ & $\mathrm{C}_{\text {гк }} / \mathrm{C}_{\text {фк }}$ \\
\hline \multicolumn{5}{|c|}{} \\
\cline { 2 - 5 } & $\frac{1,07}{34,19}$ & $\frac{1,40}{44,73}$ & $\underline{0,66}$ & 0,76 \\
\hline неосушенные &
\end{tabular}


Продолжение таблицы 2

\begin{tabular}{|l|c|c|c|c|}
\hline осушеные & $\frac{2,15}{48,75}$ & $\frac{1,86}{42,18}$ & $\frac{0,40}{9,07}$ & 1,16 \\
\hline \multicolumn{5}{|c|}{2018 год } \\
\hline неосушенные & $\frac{1,11}{34,47}$ & $\frac{1,51}{46,89}$ & $\frac{0,60}{18,63}$ & 0,74 \\
\hline осушеные & $\frac{1,65}{42,75}$ & $\frac{1,55}{40,16}$ & $\frac{0,66}{17,10}$ & 1,06 \\
\hline
\end{tabular}

Примечание числитель - \% от веса почвы, знаменатель - \% от С общ

На состав гумуса почв оказал влияние уровень агротехники, водный режим и физико-химические свойства исследуемых почв [11]. В пахотном горизонте осушенных почв к 2018 г. отношение $\mathrm{C}_{\text {гк }} / \mathrm{C}_{\text {фк }}$ уменьшилось с 1,16 до 1,06 в основном за счет сокращения содержания агрессивной фракции фульвокислот на 1,3\%. Общая же сумма гуминовых кислот сохраняется неизменной. При анализе органического вещества обращает на себя внимание увеличение в мелиорированных почвах доли негидролизуемых форм органического вещества; возможно, это явление объясняется внесением небольших доз органического вещества и изве- сти. Таким образом, можно предположить, что длительное осушение луговых почв приводит не к усилению минерализации органического вещества, а к качественному изменению его состава, что выражается в повышении в пахотном слое отношения содержания углерода гуминовых кислот к содержанию углерода фульвокислот.

При оценке валового состава луговых почв необходимо отметить отсутствие контрастных изменений (табл. 3). Однако при этом можно проследить ряд закономерных изменений, которые обусловлены влиянием осушения.

Таблица 3 - Изменения валового состава дерновых лугово-глеевых почв под влиянием осушительной мелиорации

\begin{tabular}{|l|c|c|c|c|c|c|c|}
\hline \multirow{2}{*}{$\begin{array}{c}\text { Полигоны отбора } \\
\text { проб почв }\end{array}$} & $\mathrm{SiO}_{2}$ & $\mathrm{Al}_{2} \mathrm{O}_{3}$ & $\mathrm{Fe}_{2} \mathrm{O}_{3}$ & $\mathrm{MnO}$ & $\mathrm{P}_{2} \mathrm{O}_{5}$ & $\mathrm{CaO}$ & $\mathrm{MgO}$ \\
\cline { 2 - 8 } & \multicolumn{7}{|c|}{$\%$ на прокаленную навеску } \\
\hline неосушенные & $\frac{70,05}{70,07}$ & $\frac{16,61}{16,87}$ & $\frac{8,88}{8,69}$ & $\frac{0,30}{0,27}$ & $\underline{0,53}$ & $\frac{1,48}{2,38}$ & $\frac{1,25}{2,74}$ \\
\hline осушенные & $\underline{59,88}$ & $\frac{13,47}{58,91}$ & $\frac{6,49}{6,60}$ & $\underline{0,18}$ & $\underline{0,39}$ & $\frac{1,37}{2,12}$ & $\frac{1,77}{2,38}$ \\
\hline
\end{tabular}

Примечание: числитель - 2008 год, знаменатель - 2018 год

В осушенной почве увеличение содержания валового кальция и магния происходит под влиянием не только мелиоративного, но и гидрогенного фрактора, связанного с поступлением грунтовых вод с нижележащих горизонтов, в период подтопления. Прослеживается вынос как с осушенных, так и не осушенных почв $\mathrm{Mn}$ - элемента, обладающего активной миграционной способностью. Снижается общее содержание кремнезема $\left(\mathrm{SiO}_{2}\right)$, возможно, в результате выноса аморфного кремния с дренажными водами.

Осушенные почвы обеднены подвижным фосфором, что связано с действием дренирования, небольшими дозами внесения органических и минеральных удобрений [12]. В тяжелых глинистых почвах после осушения сохраняются также анаэробные условия, при которых неподвижные фосфаты окиси железа переходят в подвижные фосфраты и поступают вначале в почвенный раствор.

По содержанию железа и алюминия в осушенных почвах происходит их снижение по отношению к неосушенным почвам. В неосушенных почвах железо примерно на 80\% находится в виде двухвалентного (закисного) железа и 20\% приходится на трехвалентное (окисное) железо. При дренировании осушительными каналами создаются условия улучшенной аэрации, способствующие снижению влажности и изменению кислотности пойменных почв в строну нейтральной $\mathrm{pH}$ среды. Это привело к возрастанию трехвалентного железа до $40 \%$. Повышенное количество $\mathrm{Fe}^{2+}$ связано с глеевыми процессами, развитие которых зависит от многообразных фракторов, к которым можно отнести условия влажности исследуемой территории, гранулометрического состава почв, химических и биологических процессов, а также содержания и форм органического вещества и др.

\section{Заключение}

Таким образом, осушение тяжелых лугово-глеевых почв Среднеамурской низменности сопровождается изменением кислотности в нейтральную сторону, содержания поглощенных оснований и степени насыщенности основаниями, а также подвижного алюминия. Снижение содержания гумуса связано со сменой анаэробных и аэробных условий при ежегодной распашке и изменением застойного водного режима на застойно-промывной, что способствует быстрой его сработке. 
Длительное осушение почв приводит не к усилению минерализации органического вещества, а к качественному изменению его состава, что выражается в повышении в пахотном слое отношения содержания углерода гуминовых кислот к содержанию углерода фульвокислот. Осушительная мелиорация без дальнейшего окультуривания отрицательно влияет на плодородие почв, ухудшая их агрохимические, фризические и другие свойства, поэтому целесообразно возобновить внесение органических и минеральных удобрений, а также проводить известкование на мелиорируемых почвах.

\section{Список литературы}

1. Разумова, Н. В. Подверженность земель Чеченской республики деградационным и опасным склоновым процессам [Текст] / Н. В. Разумова, С. И. Шагин, А. П. Притворов // Проблемы региональной экологии. 2008 - № 3. - С. 111-116.

2. Алейнов, Д. П. А готово ли наше сельское хозяйство использовать минеральные удобрения [Текст] / Д.П. Алейнов // Экономика сельскохозяйственных и перерабатывающих предприятий. 2009. - №1. - C. 6-11.

3. Зубарев, В.А. Влияние осушительной мелиорации на содержание тяжелых металлов в пойменных почвах Среднеамурской низменности [Текст] / В. А. Зубарев // Вестник Томского государственного университета. Биология. 2014. - № 4 (28). - C. 6-16.

4. Горюхин, М. В. Антропогенное преобразование пойменно-русловых комплексов рек Среднего Приамурья [Текст] / М. В. Горюхин, В. А. Зубарев, А. В. Аношкин // Известия Самарского научного центра Российской академии наук. 2016. T. 18. № 2-2. - C. 337-340

5. Zubarev, V. A. Ecological Conditions of Watercourses in the Middle Amur Lowland in the Areas of Drainage Reclamation [Текст] / V. A. Zubarev, R. M. Kogan // Water Resources. - 2017. - Vol. 44, N. 7. P. 940-951

6. Степанько, Н. Г. Анализ эколого-экономической ситуации на приграничных территориях КНР и южной зоны российского Дальнего Востока [Текст] / Н. Г. Степанько // Успехи современного естествознания. 2017. - № 11. - С. 113-122.

7. Росликова, В.И. Текстурно-диффреренцированные почвы равнин юга Дальнего Востока и их ландшафтно-географические особенности [Текст] / В.И., Росликова, Л.А. Матюшкина // Региональные проблемы. 2017. - Т. 20, № 4. - С. 53-60

8. Гольева А. А. Фитолиты в луговых почвах Среднеамурской низменности / А. А. Гольева, Л. А. Матюшкина, Г. В. Харитонова, В. С. Комарова // Тихоокеанская геология. 2014. - Т. 33, № 5. - С. 101-109.

9. Калманова, В. Б. Современные проблемы изучения почв природных и агрогенных ландшафтов Еврейской автономной области (юг Дальнего Востока) [Текст] / В. Б. Калманова // Российский журнал прикладной экологии. 2019. - № 2. - С. 21-26

10. Cao, X.D. Effects of redox potential and $\mathrm{pH}$ value on the release or rare elements from soil / X.D. Cao // Chemosphere. 2001. - V. 44. - P. 655-661.

11. Marzaioli R., D'Ascoli R., De Pascale R.A., Rutigliano F.A. Soil Quality in a Mediterranean Area of Southern Italy as Related to Different Land Use Types. Applied Soil Ecology. 2010. - V. 44. - P. 205212.

12. Бурдуковский, М.Л. Изменение агрохимических свойств основных пахотных почв юга Дальнего Востока при длительном сельскохозяйственном использовании [Текст] / М.Л. Бурдуковский. В.И. Голов, И.Г. Ковшик // Почвоведение. 2016. - № 10. - С. $1244-1250$.

\section{THE EFFECTS OF DRAINAGE ON THE CHANGE OF THE AGROCHEMICAL PROPERTIES OF MEADOW-GLEY SOILS OF THE MIDDLE AMUR LOWLEND}

Zubarev Vitaliy A., Researcher, Federal State Budgetary Institution of Science Institute for the Integrated Analysis of Regional Problems, Far Eastern Branch of the Russian Academy of Sciences. E-mail: Zubarev_1986@mail.ru

Mazhaysky Yuriy A., doctor of agricultural sciences, professor, Meschersky branch of VNIIGiM named after A. N. Kostyakov, Ryazan, mail@mntc.pro

The aim of the study was to clarify and clarify the nature and degree of change in the basic properties of agricultural meadow-gley soils under the influence of drainage reclamation. To study the effect of drainage reclamation on the state of soils in the territory of the Central Amur Lowland, field studies were conducted in 2008 and through ten tapes in 2018. For comparative analysis, undehydrated and drained, used in agricultural circulation, meadow-gley soils of the first floodplain terrace of the river valley were selected. Amur. Samples were taken from each surface test site from the surface soil horizon $(0-20 \mathrm{~cm})$ using the square method. All agrochemical analyzes were performed using conventional methods. Conducting drainage reclamation on heavy meadow-gley soils of the Middle Amur Lowland (for example, the Jewish Autonomous Region) is accompanied by a change in $\mathrm{pH}$ to the neutral side and a slight increase in the gross content of metals, absorbed bases and degree of saturation with bases. The decrease in humus content is associated with increased aeration during the annual plowing of land, a change in the water regime to stagnant-flushing, which contributes to the rapid depletion of humus. Prolonged drainage of soils does not lead to increased mineralization of organic matter, but to a qualitative change in its composition, which is reflected in an increase in the ratio of the carbon content of humic acids to the carbon content of fulvic acids in the arable layer. Drying reclamation without further cultivation negatively affects soil fertility, worsening their agrochemical, physical 
and other properties, therefore it is advisable to resume the application of organic and mineral fertilizers, as well as liming on reclaimed soils.

Key words: Middle Amur lowland, meadow-gley soils, humus, border region, drainage reclamation.

\section{Literatura}

1. Razumova, N. V. Podverzhennost' zemel' CHechenskoj respubliki degradacionnym i opasnym sklonovym processam / N. V. Razumova, S. I. SHagin, A. P. Pritvorov // Problemy regional'noj ekologii. - 2008 - № 3. - S. 111-116.

2. Alejnov, D. P. A gotovo li nashe sel'skoe hozyajstvo ispol'zovat' mineral'nye udobreniya / D.P. Alejnov // Ekonomika sel'skohozyajstvennyh i pererabatyvayushchih predpriyatij. - 2009. - № 1. - S.6-11.

3. Zubarev, V.A. Vliyanie osushitel'noj melioracii na soderzhanie tyazhelyh metallov $v$ pojmennyh pochvah Sredneamurskoj nizmennosti / V. A. Zubarev // Vestnik Tomskogo gosudarstvennogo universiteta. Biologiya. - 2014. - № 4 (28). - S. 6-16.

4. Goryuhin, M. V. Antropogennoe preobrazovanie pojmenno-ruslovyh kompleksov rek Srednego Priamur'ya / M. V. Goryuhin, V. A. Zubarev, A. V. Anoshkin // Izvestiya Samarskogo nauchnogo centra Rossijskoj akademii nauk. - 2016. - T. 18. № 2-2. - S. 337-340.

5. Zubarev, V. A. Ecological Conditions of Watercourses in the Middle Amur Lowland in the Areas of Drainage Reclamation / V. A. Zubarev, R. M. Kogan // Water Resources. - 2017. - V. 44. N. 7. - P. 940-951.

6. Stepan'ko, N. G. Analiz ekologo-ekonomicheskoj situacii na prigranichnyh territoriyah KNR i yuzhnoj zony rossijskogo Dal'nego Vostoka / N. G. Stepan'ko // Uspekhi sovremennogo estestvoznaniya. - 2017. - № 11. - S. 113-122.

7. Roslikova, V.I. Teksturno-differencirovannye pochvy ravnin yuga Dal'nego Vostoka i ih landshaftnogeograficheskie osobennosti / V.I., Roslikova, L.A. Matyushkina // Regional'nye problemy. - 2017. - T. 20, № 4. - S. 53-60.

8. Gol'eva A. A. Fitolity v lugovyh pochvah Sredneamurskoj nizmennosti/A. A. Gol'eva, L. A. Matyushkina, G. V. Haritonova, V. S. Komarova // Tihookeanskaya geologiya. 2014. - T. 33, № 5. - S. 101-109.

9. Kalmanova, V. B. Sovremennye problemy izucheniya pochv prirodnyh i agrogennyh landshaftov Evrejskoj avtonomnoj oblasti (yug Dal'nego Vostoka) / V. B. Kalmanova // Rossijskij zhurnal prikladnoj ekologii. - 2019. - № 2. - S. 21-26.

10. Cao, X.D. Effects of redox potential and $\mathrm{pH}$ value on the release or rare elements from soil /X.D. Cao // Chemosphere. - 2001. - V. 44. - P. 655-661.

11. Marzaioli R., D'Ascoli R., De Pascale R.A., Rutigliano F.A. Soil Quality in a Mediterranean Area of Southern Italy as Related to Different Land Use Types. Applied Soil Ecology. 2010. - V. 44. - P. $205-212$.

12. Burdukovskij, M.L. Izmenenie agrohimicheskih svojstv osnovnyh pahotnyh pochv yuga Dal'nego Vostoka pri dlitel'nom sel'skohozyajstvennom ispol'zovanii / M.L. Burdukovskij. V.I. Golov, I.G. Kovshik // Pochvovedenie. - 2016. - № 10. - S. 1244-1250.

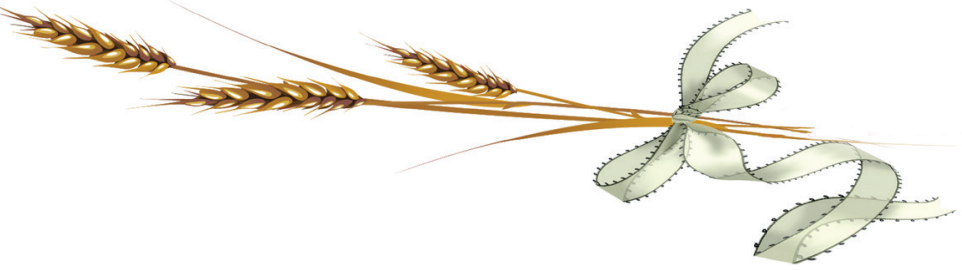

УДК 636.082.453.52

DOI 10.36508/RSATU.2020.45.1.007

\section{ВОЗРАСТНЫЕ АСПЕКТЫ ИЗМЕНЕНИЯ РЕПРОДУКТИВНОЙ ФУНКЦИИ ЖЕРЕБЦОВ-ПРОИЗВОДИТЕЛЕЙ}

КАРЕЛИНА Ольга Александровна, канд. с.-х. наук, доцент кафредры зоотехнии и биологии, olg90945056@yandex.ru

ФЕДОСОВА Ольга Александровна, канд. биол. наук, доцент кафедры зоотехнии и биологии, fedosowa1986@mail.ru

МУРАШОВА Елена Анатольевна, канд. с.-х. наук, доцент кафредры зоотехнии и биологии, murashova.36@mail.ru

ЗАЙЦЕВ Александр Михайлович, магистрант 1 курса, направление подготовки 36.04.02 Зоотехния, amzaitceff@mail.ru

Рязанский государственный агротехнологический университет имени П.А. Костычева

Проведено исследование качества спермы с учетом возраста жеребцов-производителей. Такие показатели как объем эякулята и концентрация спермиев во всех возрастных группах соответствовали действующим нормам. Показатели активности и живучести спермиев были ниже нормативного критерия у жеребцов молодого и старшего возраста, а по количеству спермиев с анормальной морфологией в этих группах данный показатель превышен в два раза. Отмечено, что количество

() Карелина О. А., Федосова О. А., Мурашова Е. А., Зайцев А. М., 2020 г. 
неполноценных спермиев у производителя уменьшается к моменту его фризиологической зрелости. У полновозрастных жеребцов наблюдалось 16,8\% патологий шейки и хвоста, однако это в 1,5-2 раза меньше по сравнению с другими возрастными группами производителей. Биохимические показатели спермы жеребцов, такие как общий белок и его фрракции, ферменты лактатдегидрогеназа, креатинфосфокиназа, щелочная фоссратаза и гамма-глутамилтранспептидаза имели возрастную динамику и характеризовались наибольшим содержанием у полновозрастных жеребцов. Так, у молодых жеребцов и жеребцов старшего возраста было отмечено наиболее низкое содержание КФК 1757,33 Ед/л и 783 Ед/л соответственно. У полновозрастных жеребцов уровень КФК составлял 1993, 25 Ед/л. Анализ результатов позволил нам выявить четкое различие между возрастными группами по активности щелочной фосфратазы: содержание ЩФ у полновозрастных жеребцов превышает данный показатель у молодых особей в 2,6 раза и в 6,2 раза у старшего возраста. Установлено, что наиболее высоко по качеству была оценена сперма полновозрастных жеребцов. Для сохранения генетического потенциала в племенной работе следует рекомендовать выборочное использование молодых перспективных жеребцов, а также использование спермы ценных жеребцов старшего возраста.

Ключевые слова: жеребцы-производители, репродуктивная функция, возраст, нативная сперма, микроскопия, биохимические показатели.

\section{Введение}

Одной из целей стратегического развития коневодства России является сохранение и совершенствование генофонда пород лошадей, разводимых в стране, а также повышение их конкурентоспособности на внутреннем и мировом рынках. В стране планируется увеличение поголовья с 1,4 млн в 2018 году до 1,6 млн к 2025 году. Эффективность любой отрасли напрямую зависит от показателей воспроизводства.

Существуют и будут совершенствоваться репродуктивные методы, которые оказывают положительное влияние на отрасль разведения лошадей, так как качество спермы самца имеет первостепенное значение для максимальной репродуктивной эфффективности [9, 14, 16].

Оплодотворяющая способность определяется рядом факторов: полноценное кормление, правильное содержание производителя, соблюдение гигиенических требований, интенсивность использования, возраст, состояние здоровья животного, сезон года и климатические условия. Перед применением биоматериал, полученный от производителя, обязательно подвергается оценке. Качество спермы с течением времени подвержено различного рода изменениям, и будет зависеть от зрелости спермиев, возбудимости. Огромное влияние оказывают фракторы внешней среды. Следовательно, для полной характеристики качества спермы необходимо проводить комплексное ее исследование [2].

По мнению ряда ученых «Самым распространенным способом сохранения генетического материала сельскохозяйственных животных и представителей дикой фауны является создание криобанков семени производителей и эмбрионов» $[6,8]$.

Атрощенко М.М. указывал на проблему снижения воспроизводственной способности в зависимости от возрастного фактора. Так, проведенные исследования показали, что у молодых жеребцов наблюдалась более высокая оплодотворяющая способность спермы, чем у животных более старшего возраста [1].

В своих исследованиях Науменкова В.А. отметила взаимосвязь возраста и качества криоконсервированной спермы. Автором был определен оптимальный возраст жеребцов для криоконсервации спермы. У жеребцов старшего возраста не только снижалось качество криоконсервированной спермы, но и наблюдалась полная потеря оплодотворяющей способности замороженно-оттаенной спермы. Поэтому к оценке качества семени возрастных жеребцов необходимо предъявлять повышенные требования [4, 5].

Такая же тенденция наблюдалась при аналогичных исследованиях на других видах сельскохозяйственных животных, где было показано, что качественные и количественные показатели спермопродуктивности определялись экстерьером, живой массой, возрастом животных $[3,7]$.

Для оценки качества спермы перед осеменением разрабатываются новые технологии: портативные устройства для анализа спермы (Ongo sperm test, ISperm и другие), проточно-цитометрический подход, метод однослойного коллоидного центрифугирования, Nucleocounter SP-100, методы оценки SMI, компьютерный метод анализа спермы (CASA) [10-13, 15]

Исходя из вышесказанного, нами была поставлена цель исследования - проанализировать влияние возрастных особенностей производителей на качество спермы. К поставленным задачам были отнесены следующие: провести макро- и микроскопические исследования биоматериала производителей, изучить показатели качества спермы у жеребцов разной возрастной категории.

\section{Материалы и методы исследования}

Объектом исследования были производители верховых, тяжелоупряжных, легкоупряжных и местных пород разных возрастных групп.

Материалом для изучения была сперма жеребцов-производителей. Сбор семени и оценка его качества осуществлялась в соответствии с «Инструкцией по искусственному осеменению и трансплантации эмбрионов лошадей».

В ходе исследований сформированы три возрастные группы производителей с учетом физиологического статуса. Первая группа была представлена молодыми жеребцами до пятилетнего возраста. Вторая группа - это жеребцы среднего зрелого возраста с 5 до 15 лет. Жеребцы старшего возраста образовали третью группу.

Эякуляты отбирали на стерильную искусствен- 
ную вагину со стерильным спермоприемником. Стерилизацию проводили в бактерицидной камере. Дезинфекцию отдельных элементов резиновой вагины осуществляли $96^{\circ}$ спиртом. Соблюдение гигиенических требований к инструментам, оборудованию и к животным позволяет получать семя высокого санитарного качества. Стерильными и безвредными должны быть и среды, которые применяются для разбавления спермы.

После получения спермы каждый эякулят был исследован по органолептическим, физическим, биологическим и морфологическим характеристикам. Оценивали по следующим показателям: запах, цвет, объем эякулята после фильтрации, концентрация спермиев, их активность (прогрессивная подвижность) в баллах и выживаемость сперматозоидов в часах при температуре $2-4{ }^{\circ} \mathrm{C}$ при разбавлении спермы 1:3 лактозо-хелато-цитратно-желточной средой. Определяли также при электронно-микроскопическом исследовании нативной спермы количество спермиев с анормальной морфологией.

С помощью мерного цилиндра определяли объем эякулята. Концентрацию сперматозоидов определяли фотометром SDM1 (Minitube $\mathrm{GmbH}$, Германия), активность оценивали с помощью светового микроскопа Микромед С-11. Выживаемость сперматозоидов характеризовали методом световой микроскопии. Контроль активности движения спермиев до прекращения их поступательного движения осуществляли, просматривая образцы, с интервалом через каждые 12 часов.
Биохимические исследования спермы с использованием анализатора «Сапфир 400» включали изучение общего белка и его фракций, а также содержание ферментов.

Результаты исследований и их обсуждение

На основе комплексной оценки определяется племенная ценность лошади и дальнейшее ее назначение. Зоотехники-селекционеры, курирующие определенную породу лошадей, на основании инструкции по бонитировке проводят оценку жеребцов, предназначенных для племенного использования. Как правило, это лошади с высокой работоспособностью и правильным экстерьером.

Главным требованием при отборе жеребцовпроизводителей для получения спермы является оценка репродуктивного статуса, включающая высокую половую потенцию и хорошее развитие органов половой системы.

Для получения биоматериала отбирают только здоровых жеребцов со всеми обязательными прививками, не привитые должны быть дополнительно обследованы. Проверка качества спермы является обязательным условием. В норме сперма должна быть без специфического запаха молочного цвета с сероватым оттенком. Сперма другого цвета с гнилостным запахом не пригодна для использования.

В ходе работы каждый образец спермы, полученный от жеребцов-производителей, был оценен по качеству. Результаты макроскопической и микроскопической оценки качества спермы представлены в таблице 1.

Таблица 1 - Показатели качества спермы жеребцов разных возрастных групп

\begin{tabular}{|l|c|c|c|c|}
\hline \multicolumn{1}{|c|}{ Группы } & V фильтрата, мл & C, млн/мл & A, баллов & Выживаемость, час \\
\hline Молодые жеребцы & 61,9 & 183,4 & 4 & 96,0 \\
\hline Полновозрастные жеребцы & 43,5 & 278,1 & 4,4 & 152,7 \\
\hline $\begin{array}{l}\text { Жеребцы } \\
\text { старшего возраста }\end{array}$ & 84,2 & 189,2 & 2,7 & 75,2 \\
\hline
\end{tabular}

В норме объем эякулята у жеребцов составляет 40-120 мл с допустимыми колебаниями от 20 до 250 мл. Концентрация спермиев должна быть не ниже 150 млн спермиев в 1 мл. Данные таблицы 1 свидетельствуют, что у жеребцов разных групп данные характеристики спермы соответствовали техническим условиям (ГОСТ-23681-79).

Активность спермиев оценивали по 10-балльной шкале. Для этого под микроскопом в поле зрения глазомерно подсчитывали в процентах к общему числу спермиев количество сперматозоидов с активным прямолинейно-поступательным движением. По действующему стандарту подвижность спермиев должна быть не менее 5 баллов.

Показатель живучести спермы выражают в часах. Контроль активности движения спермиев проводили до полного прекращения их поступательного движения, и их выживаемость должна быть не менее 150 часов. Исследуемые биообразцы жеребцов молодого и старшего возраста не соот- ветствовали этим критериям.

Если судить о функциональном состоянии двигательной системы сперматозоидов жеребцов разных возрастных групп, то наибольшая подвижность спермиев наблюдалась у полновозрастных производителей (4,4 балла). Самая низкая активность отмечена у жеребцов старшего возраста и в среднем была оценена на 2,7 балла. Такая же тенденция наблюдалась и по показателю живучести спермиев. У молодых жеребцов выживаемость спермиев равнялась 96 часам, у средневозрастных - 152,7 часа, у жеребцов старшего возраста - 75,2 часа.

Итак, наиболее высоко по качеству была оценена сперма полновозрастных жеребцов. Однако перспективных молодых жеребцов, а также выдающихся производителей старшего возраста, которые имеют большую ценность для породы, рекомендуется использовать для искусственного осеменения. 
Если после определения качества спермы выявлены нормативные отклонения по какому-то показателю, то такая сперма подлежит выбраковке, а производитель не используется до установления состояния полового аппарата путем клинических и лабораторных исследований.

Было проведено электронно-микроскопическое исследование нативной спермы жеребцов, так как анализ семени также включает определение общего количества спермиев в препарате по методике подсчета клеток при морфологических исследованиях, морфологии спермиев. Нормальные и патологические спермии выявляются при микроскопическом исследовании спермы. Общее количество сперматозоидов в поле зрения нативной спермы и процент морфологических аномалий показан в таблице 2.

Таблица 2 - Общее количество сперматозоидов в эякуляте в зависимости от возраста жеребцов

\begin{tabular}{|l|c|c|c|}
\hline \multicolumn{1}{|c|}{ Группы } & $\begin{array}{c}\text { Общ. кол-во } \\
\text { спермотозойдов в п/3 }\end{array}$ & Нормальные, \% & Атипичные, \% \\
\hline Молодые жеребцы & 374 & 55,7 & 44,3 \\
\hline Полновозрастные жеребцы & 633 & 77,3 & 22,8 \\
\hline Жеребцы старшего возраста & 340 & 58,1 & 41,9 \\
\hline
\end{tabular}

Анализ таблицы 2 показал, что общее количество сперматозоидов у полновозрастных жеребцов в два раза выше, чем у других изучаемых групп.

В свежеполученной неразбавленной сперме количество спермиев с анормальной морфологией должно быть не более 20\%. У молодых и старых жеребцов данный показатель превышен в два раза.

В практике обычно выделяют две группы патологических изменений формы спермиев: сперматозоиды с отклоняющейся от нормы формой и величиной головки, и сперматозоиды с отступающей от нормы формой шейки и хвоста. При исследованиях можно наблюдать различные неправильные формы спермиев: мужская половая клетка гигантского или, наоборот, карликового размера; спермии с общим хвостиком, но двумя или тремя головками; с маленькой или большой головкой; с отсутствующим, с укороченным, надломленным или закрученным хвостиком, с двумя хвостиками; с протоплазматической капелькой на головке, шейке или жгутике, и другие формы. Иногда встречаются спермии, лишенные головки, но способные двигаться. Уродливые формы сперми- ев возникают по ряду причин: воспаление семенника и придатка, длительные промежутки между коитусами, половое истощение, нарушение терморегулирующей функции мошонки и другие

Изменения показателей аномальной морфологии отдельных сегментов сперматозоидов в зависимости от возраста производителей показаны в таблице 3.

Большое количество патологических спермиев свидетельствует о нарушении спермиогенеза, поэтому подсчет количества патологических форм спермиев необходим для выявления тератоспермии.

Из анализа таблицы 3 следует, что чаще аномалии в строении сперматозоидов встречались в хвостовой части спермиев. У полновозрастных жеребцов наблюдалось $16,8 \%$ патологий шейки и хвоста, однако это в 1,5-2 раза меньше по сравнению с другими возрастными группами производителей. Незрелые спермии, как правило, появляются вследствие большой половой нагрузки. Капелька, расположенная близко к головке, свидетельствует о незрелости спермия. В изучаемых группах выявлены 0,9-2,5\% сперматозоидов с патологией головки.

Таблица 3 - Показатели аномальной морфологии отдельных сегментов сперматозоидов

\begin{tabular}{|c|c|c|c|}
\hline \multirow[b]{2}{*}{ Показатели } & \multicolumn{3}{|c|}{ Возрастные группы } \\
\hline & $\begin{array}{l}\text { молодые } \\
\text { жеребцы }\end{array}$ & $\begin{array}{c}\text { полновозрастные } \\
\text { жеребцы }\end{array}$ & $\begin{array}{c}\text { жеребцы старшего } \\
\text { возраста }\end{array}$ \\
\hline Патология головки, \% & 2,5 & 0,9 & 1,2 \\
\hline $\begin{array}{l}\text { в том числе: } \\
\qquad \text { микроголовки }\end{array}$ & 0,3 & 0,4 & 0,5 \\
\hline аморфные головки & 2,0 & 0,4 & 0,6 \\
\hline $\begin{array}{l}\text { глобулярные } \\
\text { головки }\end{array}$ & 0,2 & 0,1 & 0,1 \\
\hline Цитоплазм. капли,\% & 0,8 & 1,8 & 3,8 \\
\hline
\end{tabular}


Продолжение таблицы 3

\begin{tabular}{|c|c|c|c|}
\hline $\begin{array}{l}\text { в том числе: } \\
\text { капля на головке }\end{array}$ & 0,4 & 0,2 & 0,5 \\
\hline $\begin{array}{r}\text { капля на средней } \\
\text { части } \\
\end{array}$ & 0 & 0 & 0,4 \\
\hline капля на жгутике & 0 & 0,1 & 1,6 \\
\hline $\begin{array}{l}\text { Патология шейки } \\
\text { и хвоста, \% }\end{array}$ & 34,5 & 16,8 & 23,4 \\
\hline $\begin{array}{l}\text { в том числе: } \\
\text { укороченный жгутик }\end{array}$ & 0 & 0,5 & 0,1 \\
\hline закрученный жгутик & 13,6 & 6,8 & 14,8 \\
\hline $\begin{array}{r}\text { жгутик надломанный } \\
\text { посередине } \\
\end{array}$ & 1,65 & 0,7 & 0 \\
\hline $\begin{array}{c}\text { утолщ. нач. и ср. } \\
\text { части жгутика }\end{array}$ & 0 & 0,1 & 0 \\
\hline Гетероаксиальность, \% & 19,3 & 8,7 & 8,5 \\
\hline Единичные головки, \% & 2,6 & 1,96 & 9,2 \\
\hline Единичные хвосты, \% & 3,35 & 1,5 & 3,2 \\
\hline 2-х головые, \% & 0 & 0 & 0,7 \\
\hline Два хвоста, \% & 0,1 & $\mathbf{0}$ & 0,4 \\
\hline 2-х гол. и 2-х хвост, \% & 0,1 & $\begin{array}{llll}0 & & & \\
\end{array}$ & 1,1 \\
\hline
\end{tabular}

Показатели жеребцов среднего возраста свидетельствуют о том, что количество аномальных спермиев уменьшается к моменту фризиологической зрелости производителя. Значительное количество аномальных спермиев у жеребцов старшего возраста можно рассматривать как признак наступающей импотенции.

В настоящее время актуальным является комплексный подход к изучению связи биохимических показателей спермоплазмы с качественными характеристиками эякулята. Такой подход способствует поиску новых решений в проблеме вос- производства, получения здорового плодовитого потомства.

Результаты исследования показали, что содержание общего белка у молодых жеребцов находилось на уровне 21,9 г/л (табл. 4). Тогда как у полновозрастных жеребцов данный показатель был выше и составлял 29,73 г/л. На наш взгляд, такой характер возрастных изменений общего белка связан с повышением оплодотворяющей способности спермы жеребцов, поскольку это приводит к увеличению скорости и числа активно подвижных спермиев.

Таблица 4 - Общий белок и его фракции в сперме жеребцов в зависимости от возраста

\begin{tabular}{|l|c|c|c|}
\hline \multirow{2}{*}{ Возрастные группы } & Общий белок, г/л & \multicolumn{2}{|c|}{ Фракции белков } \\
\cline { 3 - 4 } & & Альбумины, г/л & Глобулины, г/л \\
\hline $\begin{array}{l}\text { Молодые } \\
\text { жеребцы }\end{array}$ & 21,9 & 9,23 & 11,9 \\
\hline $\begin{array}{l}\text { Полновозрастные } \\
\text { жеребцы }\end{array}$ & 29,73 & 9,83 & 19,9 \\
\hline $\begin{array}{l}\text { Жеребцы } \\
\text { старшего возраста }\end{array}$ & 13,6 & 8,4 & 5,2 \\
\hline
\end{tabular}

Анализ белковых фракций в сперме жеребцов всех возрастных групп позволил установить, что наибольшее содержание альбуминов и глобулинов отмечено у полновозрастных жеребцов (табл. 4). На наш взгляд, это объясняется повышенной активностью неспецифических звеньев иммунитета, в основном, ү-глобулинов, в связи с активизацией репродуктивной функции. При этом минимальные значения отмечены у жеребцов старшего возраста.

Фертильность спермы во многом определяется активностью ферментов. У молодых жеребцов со- 
держание ЛДг было равно 709,63 Ед/л, тогда как у полновозрастных оно превышало этот уровень на 358 Ед/л (табл. 5). По всей вероятности, это связано с функциональной ролью ЛДГ, которая заклю-

Таблица 5 - Ферменты в сперме жеребцов в зависимости от возраста

\begin{tabular}{|l|c|c|c|}
\hline $\begin{array}{c}\text { Активность фрерментов, } \\
\text { Ед/л }\end{array}$ & $\begin{array}{c}\text { Молодые } \\
\text { жеребцы }\end{array}$ & $\begin{array}{c}\text { Жолнребцы } \\
\text { жеребрастные }\end{array}$ \\
\hline ЛДГ & 709,63 & 1068 & 443,64 \\
\hline КФК & 1757,33 & 1993,25 & 783 \\
\hline ЩФ & 1,1 & 2,87 & 0,46 \\
\hline ГГТП & 0,9 & 1,4 & 0,54 \\
\hline व-амилаза & 2,67 & 2,78 & 2,21 \\
\hline
\end{tabular}

Анализ результатов исследований позволил установить, что активность креатинфосфокиназы (КФК) спермоплазмы жеребцов имела возрастные изменения (табл. 5). Так, у молодых жеребцов и жеребцов старшего возраста было отмечено более низкое содержание данного фермента (1757,33 Ед/л и 783 Ед/л соответственно), в то время как у полновозрастных жеребцов активность КФК была равна 1993,25 Ед/л. Согласно литературным данным, КФК отвечает за энергетическое обеспечение спермиев; увеличение активности данного фермента у полновозрастных жеребцов связано с более высоким числом активно подвижных спермиев.

Щелочная фосфратаза (ЩФ) обеспечивает создание оптимальных фризико-химических свойств спермы. Анализ таблицы 5 позволил выявить четкое различие между возрастными группами: со- чается в диссимиляции моносахаридов - глюкозы и фрруктозы, служащих основными энергетическими субстратами спермиев. держание ЩФ у полновозрастных жеребцов превышает данный показатель у молодых особей в 2,6 раза и в 6,2 раза у старшего возраста (рис.).

Известно, что гамма-глутамилтранспептидаза (ГГТП) отвечает за транспорт аминокислот в спермии. Проведенное исследование показало, что максимальное содержание ГГТП наблюдалось у полновозрастных жеребцов и составляло 1,4 Ед/л.

а-амилаза отвечает за расщепление полисахаридов до низкомолекулярных сахаров, тем самым создавая, непосредственно или опосредованно через другие ферментативные системы, энергетический субстрат для спермиев. Говоря о возрастной динамике а-амилазы, мы не наблюдали значительных возрастных изменений. Активность а-амилазы изменялась в диапазоне от 2,21 Ед/л и до 2,78 Ед/л.

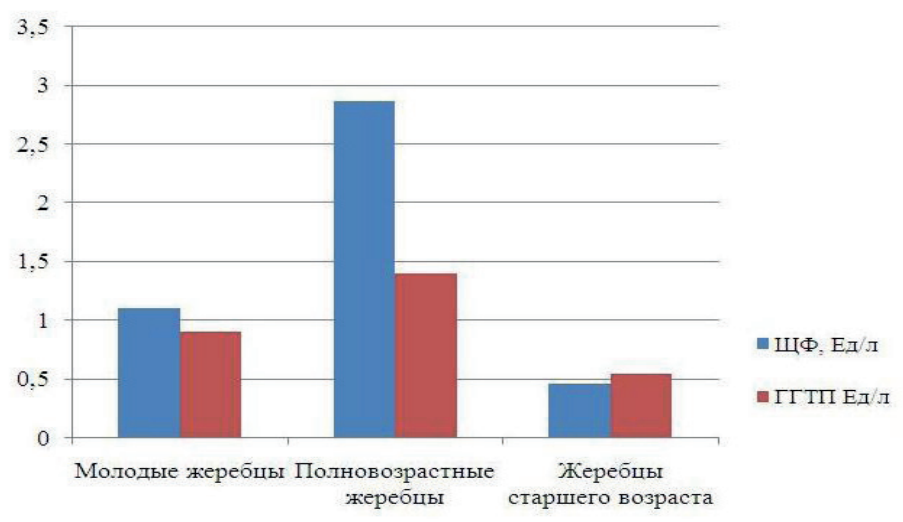

Рис.- Активность фрерментов в сперме жеребцов различных возрастных групп.

Следует отметить, что все изученные биохимические показатели спермы находились в пределах фризиологической нормы, что говорит о здоровье животных и стабильных обменных процессах.

\section{Выводы}

Так как результаты искусственного осеменения самок во многом зависят от качества спермиев, то, анализируя полученные в ходе исследований данные, можно сделать следующие выводы:

- установлена определенная взаимосвязь между качеством спермы и возрастом жеребцовпроизводителей;
- эякулят с повышенным содержанием аномальных сперматозоидов может указывать на снижение фертильности спермы;

- установлено, что содержание общего белка и его фракций, ферментов ЛДГ, ЩФ, КФК, ГГТП имеет возрастные различия, и наибольшее значение оно составляет у полновозрастных жеребцов;

- наиболее высоко по качеству была оценена сперма полновозрастных жеребцов;

- для сохранения генетического потенциала в племенной работе следует рекомендовать выборочное использование молодых перспективных 
жеребцов, а также использование спермы ценных жеребцов старшего возраста.

\section{Список литературы}

1. Атрощенко, М.М. Анализ репродуктивных качеств племенных жеребцов разных возрастных групп [Текст] / М.М. Атрощенко // Актуальные вопросы сельскохозяйственной биологии. - 2019. № 1 (11). - С. 3-12.

2. Белобороденко, А.М. Биотехника воспроизводства с основами акушерства[Текст] / А.М. Белобороденко, И.А. Родин, М.А. Белобороденко, Т.А. Белобороденко. - Тюмень: ГА УСЗ, 2015. - 554 с.

3. Гончаров, В.В. К вопросу об искусственном осеменении криоконсервации спермы северных оленей [Текст] / В.В. Гончаров, Е.В. Никиткина // Сб.: «TerraАрктика-2016: Биологические ресурсы и рациональное природопользование / Генетика и разведение животных»: Материалы Международной научно-практической конференции. - 2016. №2. - C. 3-7.

4. Науменкова, В.А. Качество криоконсервированной спермы жеребцов в зависимости от возраста [Текст] / В.А. Науменкова // Сб.: Современные достижения и актуальные проблемы в коневодстве : Материалы международной научнопрактической конференции. - 2019. - С. 190-195.

5. Науменкова, В.А. Оптимальный возраст жеребцов для эффективной криоконсервации спермы [Текст] / В.А. Науменкова // Коневодство и конный спорт. - 2016. - № 6. - С. 13-15.

6. Науменкова, В.А. Уникальный опыт криоконсервации семени жеребцов [Текст] / В.А. Науменкова, М.В. Адамковская, О.Л.Филимонова // Коневодство и конный спорт. - 2010. - № 2. - С. 23-24.

7. Шамшидин, А.С. Эффрективность использования импортированных и отечественных быков-производителей мясных пород в зависимости от экстерьера, живой массы и возраста [Текст] / А.С. Шамшидин, Н.Ж. Кажгалиев, А. Маханбетова, С. Майгарин // Вестник Мичуринского государственного аграрного университета. - 2018. - № 3. - С. 131-140.

8. Atroshchenko, M.M.Conservation of genetic resources in horse breeding and major structural damages of sperm during semen cryopreservation in stallions [Текст] / M.M.
Atroshchenko, E.E. Bragina, A.M. Zaitsev, V.V. Kalashnikov, V.A. Naumenkova, A.M. Kudlaeva, E.V. Nikitkina // Nature Conservation Research. Заповедная наука. - 2019. - 4(Suppl.2): 78-82.

9. Atroshchenko, M.M. Comparative study of the structural integrity of spermatozoa in epididymal, ejaculated and cryopreserved semen of stallions [Текст]/M.M. Atroshchenko, V.V. Kalaschnikov, Ye.Ye. Bragina, A.M. Zaitsev // Sel'skokhozyaistvennaya biologiya. - 2017. - 52(2): 274-281.

10. Buss, T. Evaluation of a portable device for assessment of motility in stallion semen [Текст] / T. Buss, J. Aurich, C. Aurich // Reproduction in Domestic Animals. - 2019. - № 54(3). - p. 514-519.

11. Dini, P. Validation of a portable device (iSperm®) for the assessment of stallion sperm motility and concentration[Текст] / P. Dini, L. Troch, I. Lemahieu, P. Deblende, P. Daels // Reproduction in Domestic Animals. - 2019. - Volume 54. - Issue 8. - Pages 1113-1120.

12. Foster, M.L. Comparison of methods for assessing integrity of equine sperm membranes [Текст] / M.L. Foster, C.C. Love, D.D. Varner, K. LaCaze, T.L. Blanchard // Theriogenology. - 2011. Volume 76. - Issue 2. - Pages 334-341.

13. Giaretta, E. Implementing an open-access CASA software for the assessment of stallion spermmotility: Relationship with other sperm quality parameters [Текст]/E. Giaretta, M. Munerato, M. Yeste, G. Mari, D. Bucci // Animal Reproduction Science. - 1 January 2017. - Volume 176. - Pages 11-19.

14. Gottschalk, M. Relationships among stallion fertility and semen traits using estimated breeding values of German Warmblood stallions [Текст] / M. Gottschalk, H. Sieme, G. Martinsson, O. Distl // Theriogenology. -1 February 2017. - Volume 89. Pages 68-71.

15. Graham, J.K. Assessment of sperm quality: A flow cytometric approach [Текст] / J.K. Graham // Animal Reproduction Science. - 3 December 2001. Volume 68. - Issue 3-4. - Pages 239-247.

16. Squires, E.L. Integration of future biotechnologies into the equine industry [Текст] / E.L. Squires // Animal Reproduction Science. - 2005. Volume 89. - Issue 1-4. - Pages 187-198.

\section{AGE ASPECTS OF CHANGE OF REPRODUCTIVE FUNCTION TREASURES MANUFACTURERS}

Karelina Olga A., cand. of agricultural sciences, associate Professor of the Department of animal science and biology, olg90945056@yandex.ru

Fedosova Olga A., cand. biol. associate Professor of the Department of animal science and biology, fedosowa1986@mail.ru

Murashova Elena A., cand. of agricultural sciences, cand. of agricultural sciences, associate Professor of the Department of animal science and biology, ,murashova.36@mail.ru

Zaitsev Alexander M., 1st year undergraduate specialization 36.04.02 Zootechny, associate Professor of the Department of animal science and biology, amzaitceff@mail.ru

Ryazan state agrotechnological University named after P. A. Kostychev

A study of the quality of sperm, taking into account the age of the stallions-producers. Such indicators as the volume of ejaculate and the concentration of sperm in all age groups corresponded to current standards. Sperm activity and vitality were lower than the normative criterion for young and older stallions, and this 
indicator was doubled in the number of sperm with abnormal morphology in these groups. It is noted that the number of defective sperms in the producer decreases by the time of its physiological maturity. In full-aged stallions, $16.8 \%$ of pathologies of the neck and tail were observed, but this is 1.5-2 times less compared to other age groups of producers. Biochemical parameters of stallion sperm, such as total protein and its fractions, enzymes lactate dehydrogenase, creatine phosphokinase, alkaline phosphatase and gammaglutamyltranspeptidase, had age-related dynamics and were characterized by the highest content in full-aged stallions. So, among young stallions and older stallions, the lowest CPK content was $1757.33 \mathrm{U} / \mathrm{L}$ and 783 $U / L$, respectively. In full-aged stallions, the CPK level was 1993.25 U / L. An analysis of the results allowed us to identify a clear difference between age groups in alkaline phosphatase activity: the content of alkaline phosphatase in full-aged stallions exceeds this indicator in young individuals by 2.6 times and 6.2 times in older adults. It was established that sperm of full-aged stallions was rated the highest in quality. To preserve the genetic potential in breeding, we recommend the selective use of promising young stallions, as well as the use of sperm of valuable older stallions.

Key words: producer stallions, reproductive function, age, native sperm, microscopy, biochemical parameters.

\section{Literatura}

1. Atroshchenko, M.M. Analiz reproduktivnyh kachestv plemennyh zherebcov raznyh vozrastnyh grupp [Tekst] / M.M. Atroshchenko// Aktual'nye voprosy sel'skohozyajstvennoj biologii. - 2019. - № 1 (11). - S. 3-12.

2. Beloborodenko, A.M. Biotekhnika vosproizvodstva s osnovami akusherstva[Tekst]/A.M. Beloborodenko, I.A. Rodin, M.A. Beloborodenko, T.A. Beloborodenko. - Tyumen': GA USZ, 2015. - 554 s.

3. Goncharov, V.V. K voprosu ob iskusstvennom osemenenii kriokonservacii spermy severnyh olenej [Tekst] / V.V. Goncharov, E.V. Nikitkina // Sb.: "TerraArktika-2016: Biologicheskie resursy i racional'noe prirodopol'zovanie / Genetika i razvedenie zhivotnyh»: Materialy Mezhdunarodnoj nauchno-prakticheskoj konferencii. - 2016. - №2. - S. 3-7.

4. Naumenkova, V.A. Kachestvo kriokonservirovannoj spermy zherebcov v zavisimosti ot vozrasta [Tekst] / V.A. Naumenkova // Sb.: Sovremennye dostizheniya i aktual'nye problemy v konevodstve : Materialy mezhdunarodnoj nauchno-prakticheskoj konferencii. - 2019. - S. 190-195.

5. Naumenkova, V.A. Optimal'nyj vozrast zherebcov dlya effektivnoj kriokonservacii spermy [Tekst] / V.A. Naumenkova // Konevodstvo i konnyj sport. - 2016. - № 6. - S. 13-15.

6. Naumenkova, V.A. Unikal'nyj opyt kriokonservacii semeni zherebcov [Tekst] / V.A. Naumenkova, M.V. Adamkovskaya, O.L.Filimonova // Konevodstvo i konnyj sport. - 2010. - № 2. - S. 23-24.

7. SHamshidin, A.S. Effektivnost' ispol'zovaniya importirovannyh i otechestvennyh bykov-proizvoditelej myasnyh porod v zavisimosti ot ekster'era, zhivoj massy i vozrasta [Tekst]/A.S. SHamshidin, N.ZH. Kazhgaliev, A. Mahanbetova, S. Majgarin // Vestnik Michurinskogo gosudarstvennogo agrarnogo universiteta. - 2018. - № 3. - S. 131-140.

8. Atroshchenko, M.M. Sonservation of genetic resources in horse breeding and major structural damages of sperm during semen cryopreservation in stallions [Tekst]/M.M. Atroshchenko, E.E. Bragina, A.M. Zaitsev, V.V. Kalashnikov, V.A. Naumenkova, A.M. Kudlaeva, E.V. Nikitkina // Nature Conservation Research. Zapovednaya nauka. - 2019. - 4(Suppl.2): 78-82.

9. Atroshchenko, M.M. Comparative study of the structural integrity of spermatozoa in epididymal, ejaculated and cryopreserved semen of stallions [Tekst] / M.M. Atroshchenko, V.V. Kalaschnikov, Ye. Ye. Bragina, A.M. Zaitsev // Sel'skokhozyaistvennaya biologiya. - 2017. - 52(2): 274-281.

10. Buss, T. Evaluation of a portable device for assessment of motility in stallion semen [Tekst] / T. Buss, J. Aurich, C. Aurich // Reproduction in Domestic Animals. - 2019. - № 54(3). - r. 514-519.

11. Dini, P. Validation of a portable device (iSperm $\left.{ }^{\circledR}\right)$ for the assessment of stallion sperm motility and concentration [Tekst] / P. Dini, L. Troch, I. Lemahieu, P. Deblende, P. Daels // Reproduction in Domestic Animals. - 2019. - Volume 54. - Issue 8. - Pages 1113-1120.

12. Foster, M.L. Comparison of methods for assessing integrity of equine sperm membranes [Tekst]/ M.L. Foster, C.C. Love, D.D. Varner, K. LaCaze, T.L. Blanchard // Theriogenology. - 2011. - Volume 76. - Issue 2. - Pages 334-341.

13. Giaretta, E. Implementing an open-access CASA software for the assessment of stallion spermmotility: Relationship with other sperm quality parameters [Tekst] / E. Giaretta, M. Munerato, M. Yeste, G. Mari, D. Bucci // Animal Reproduction Science. - 1 January 2017. - Volume 176. - Pages 11-19.

14. Gottschalk, M. Relationships among stallion fertility and semen traits using estimated breeding values of German Warmblood stallions [Tekst] / M. Gottschalk, H. Sieme, G. Martinsson, O. Distl // Theriogenology. -1 February 2017. - Volume 89. - Pages 68-71.

15. Graham, J.K. Assessment of sperm quality: A flow cytometric approach [Tekst]/J.K. Graham // Animal Reproduction Science. - 3 December 2001. - Volume 68. - Issue 3-4. - Pages 239-247.

16. Squires, E.L. Integration of future biotechnologies into the equine industry [Tekst] / E.L. Squires // Animal Reproduction Science. - 2005. - Volume 89. - Issue 1-4. - Pages 187-198. 


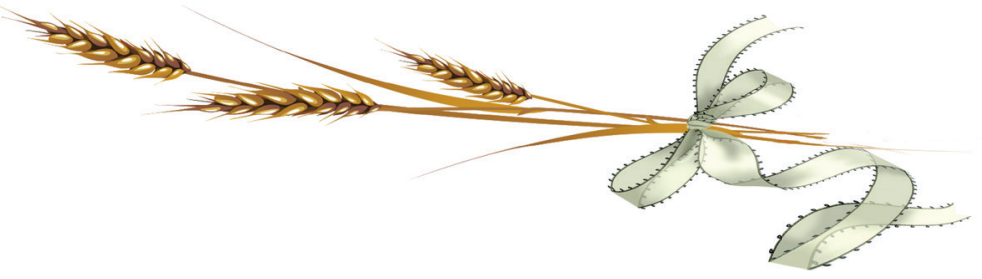

УДК 628.381.4

DOI 10.36508/RSATU.2020.45.1.008

\section{АГРОМЕЛИОРАТИВНАЯ ОЦЕНКА ПРИМЕНЕНИЯ ПОДГОТОВЛЕННЫХ ЖИДКИХ ОТХОДОВ СВИНОКОМПЛЕКСОВ НА ЧЕРНОЗЕМЕ ОБЫКНОВЕННОМ КРАСНОДАРСКОГО КРАЯ}

КОЛЕСНИКОВА Татьяна Андреевна ст. преподаватель, Южно-Российский государственный политехнический университет (НПИ) имени М.И. Платова, tanechka-ko1986@yandex.ru

КУЛИКОВА Марина Анатольевна, канд. техн. наук, доцент Южно-Российский государственный политехнический университет (НПИ) имени М.И. Платова,ту7rysyk@mail.ru

За последние пять лет поголовье свиней в России увеличилось в связи введением санкций на импорт мяса. С каждым годом возрастает антропогенная нагрузка человечества на агроценозы, что пагубно сказывается на состоянии и качестве урожая. Высокое негативное воздействие оказывают жидкие отходы свинокомплексов, занимая большие площади сельскохозяйственных земель и загрязняя окружающую среду. При этом жидкие отходы свинокомплексов являются источником ценных компонентов, способных улучшить агромелиоративные показатели селскохозяйственных земель. Одновременно с этим на территории Краснодарского края имеется большое количество предприятий по по производству сахара, в результате деятельности которых образуются крупнотоннажные органические отходы: дефрекационная известь, дефекат. Дефрекат сахарного производства отличается высоким содержанием кальция и ценных органических компонентов. Дефрекационная известь сахарного производства содержит до 84\% активного СаО, необходимого для подготовки жидких отходов свинокомплексов. В работе представлены результаты исследований возможности безопасного применения подготовленных жидких отходов свинокмплексов на черноземе обыкновенном Староминского района Краснодарского края. Проведена агромелиоративная оценка подготовленных реагентами жидких отходов свинокомплексов, показавшая их высокую эффрективность по минимизации деградации земель и восстановлению содержания питательных веществ в почве. Авторами установлено снижение уровня содержания солей в почве при использовании подготовленных жидких отходов свинокомплексов, обработанных реагентами, приготовленными на основе отходов свеклосахарного производства. Представлены результаты исследований водно-фризических свойств почв, содержания гумуса, нитратного азота и подвижного фоссфора, солевого состава почв при применении жидких отходов свинокомплексов.

Ключевые слова: агромелиоративная оценка, жидкие отходы свинокомплексов, реагентная обработка, дефрекационная известь, свекловичный жом, плодородие, удобрения.

\section{Введение}

Опыт изучения зарубежных и отечественных публикаций $[2,3,5-7,9]$ свидетельствует о практике применения жидких отходов для восстановления деградированных земель и увеличения питательных веществ в почве. Тип почвы, химический и бактериологический состав жидких отходов свинокомплексов, методы и условия реагентной обработки, особенности выращивания сельскохозяйственных культур определяют разную степень влияния на плодородие почв [11-16]. Внесение подготовленных сточных вод свинокомплексов улучшает агромелиоративные показатели почв, но требует детального изучения самого процесса реагентной подготовки жидких отходов и их влияния на окружающую среду [8].

Целью работы является агромелиоративная оценка применения подготовленных жидких отходов свинокомплексов на черноземе обыкновенном Краснодарского края.
Научная новизна заключается в исследовании воздействия жидких отходов свинокомплекса, подготовленных к применению на сельскохозяйственных угодьях с использованием различных реагентов, на плодородие, экологическое состояние и агромелиоративные показатели почв.

\section{объекты и методы}

Опытный участок расположен в Староминском районе Краснодарского края, на площади 10 га выращивали кормовую кукурузу. Почва на исследуемом участке относится к 1-ой Северной зоне, подзоне «Б», представлена черноземами обыкновенным, мощным и сверхмощным. Содержание гумуса составляет 4,0-5,0\%. Структура сухой почвы при просеивании отличная, водопрочность агрегатов хорошая, нижние горизонты почвы слабообеспечены влагой и питательными компонентами, так как уже на глубине 20-40 см сильно уплотнены.Черноземы исследуемого участка в слоях 0-20 и 20-40 см незасолены и не подвергнуты процес-

() Колесникова Т. А., Куликова М. А., 2020 г. 
сам ощелачивания и осолонцевания.

Для подготовки жидких отходов свинокомплекса ст. Староминской к внесению в почву использовали отходы свеклосахарного производства ст. Ленинградской; эти предприятия являются крупными производителями отходов. В данный момент указанные отходы практически не утилизируются, ввиду отсутствия эфффективных и экологически безопасных методов переработки.

\section{Экспериментальная часть}

Подготовленные жидкие отходы свинокомплексов имеют специфический состав, обусловленный присутствием в них органических и минеральных компонентов, которые могут изменять состав и свойства почвы.

Обработку почвы осуществляли жидкими отходами свинокомплексов, подготовленными следую- щим образом. В жидкие отходы свинокомплексов последовательно вводился щелочной коагулянт суспензия дефекационной извести сахарного производства или суспензия дефеката сахарного производства до значения $\mathrm{pH}=12-13$ и подкисляющий реагент - аммофос до значения $\mathrm{pH}=6,5-8,0$. Происходит разделение на жидкую фракцию и осадок, далее смешиваемый со свекловичным жомом в соотношении (1-2):(5-7). Состав жидкой фрракции и осадка, полученных в результате реагентной обработки, представлен в таблице 1. Подготовленные таким образом жидкие отходы свинокомплексов распределяли и дисковали поделяночным дискатором, равномерно заделывая в почву на глубину 10-15 см. Почва исследуемого участка имела агрохимические свойства, представленные в таблице 2.

Таблица 1 - Физико-химические показатели подготовленных жидких отходов свинокомплекса

\begin{tabular}{|c|c|c|}
\hline Показатели & $\begin{array}{l}\text { Жидкая фраза после } \\
\text { обработки }\end{array}$ & Осадок после обработки \\
\hline $\begin{array}{l}\text { Показатель активности водородных } \\
\text { ионов (реакция водной среды), pH, ед }\end{array}$ & 8,0 & 8,1 \\
\hline Влажность, \% & 100 & 91,0 \\
\hline Зольность, \% & - & 43,0 \\
\hline Массовая доля сух. вещества, \% & - & 9,0 \\
\hline $\begin{array}{l}\text { Органическое вещество, \% в сухом } \\
\text { веществе }\end{array}$ & - & 72,6 \\
\hline Углерод, \% & - & 29,1 \\
\hline $\mathrm{N}-\mathrm{NH} 4, \%$ & 0,3 & 0.9 \\
\hline $\mathrm{N}_{\text {общ }}, \%$ в сухом веществе & 1,5 & 3,8 \\
\hline $\mathrm{P}_{\text {общ }}, \%$ в сухом веществе & 1,0 & 11,0 \\
\hline $\mathrm{K}_{\text {общ }}, \%$ в сухом веществе & 0,2 & 0,6 \\
\hline
\end{tabular}

Как видно из данных таблицы 1, подготовленные сточные воды свинокомплекса обладают высокой удобрительной ценностью, содержат в себе сухого органического вещества $72,6 \%$, в расчете на 1 т 154 кг NPK, 9 кг аммонийного азота.

Таблица 2 - Агрохимичекие свойства почвы исследуемого участка

\begin{tabular}{|c|c|c|c|c|c|c|c|c|c|}
\hline \multirow[b]{2}{*}{ Слой, см } & \multirow{2}{*}{$\begin{array}{c}\text { Подвижные } \\
\text { соединения } \\
\text { фоссрора, } \\
\text { P2О5, мг/кг } \\
\end{array}$} & \multirow{2}{*}{$\begin{array}{c}\text { Обменные } \\
\text { фрормы калия } \\
\text { К2О, } \\
\text { мг/кг }\end{array}$} & \multirow{2}{*}{$\begin{array}{c}\text { Азот ни- } \\
\text { тратный, } \\
\text { мг/кг }\end{array}$} & \multirow[b]{2}{*}{$\begin{array}{c}\text { Гумус, } \\
\%\end{array}$} & \multirow[b]{2}{*}{$\begin{array}{l}\text { pH соле- } \\
\text { вой, ед }\end{array}$} & \multicolumn{4}{|c|}{ Токсичные элементы, мг/кг } \\
\hline & & & & & & $\mathrm{Pb}$ & $\mathrm{Cd}$ & $\mathrm{Ni}$ & $\mathrm{Cu}$ \\
\hline $0-20$ & 25,9 & 655 & 4.3 & 5.43 & 7.6 & 18.4 & 0.23 & 39.8 & 20.5 \\
\hline $20-40$ & 20,1 & 575 & 3,9 & 5,21 & 7,6 & 18,1 & 0,22 & 38,1 & 21,8 \\
\hline
\end{tabular}

В результате внесения полученных подготовленных жидких отходов свинокомплекса на черноземе обыкновенном в Староминском районе Краснодарского края происходило изменение их водно-фризических свойств (таблицы 3,4).

Таблица 3 - Изменение водно-физических свойств почвы при внесении жидкой фазы подготовленных отходов свинокомплекса (2016-2019 гг)

\begin{tabular}{|c|c|c|c|c|c|c|c|c|}
\hline $\begin{array}{c}\text { Глубина } \\
\text { горизонта } \\
\text { см }\end{array}$ & \multicolumn{2}{|c|}{ Удельный вес, г/см ${ }^{3}$} & \multicolumn{2}{|c|}{ Объёмный вес, г/см ${ }^{3}$} & \multicolumn{2}{|c|}{ Пористость, \% } & \multicolumn{2}{|c|}{ Влагоёмкость, \% } \\
\cline { 2 - 9 } & контроль & $\begin{array}{c}\text { после } \\
\text { внесения }\end{array}$ & контроль & $\begin{array}{c}\text { после } \\
\text { внесения }\end{array}$ & контроль & $\begin{array}{c}\text { после } \\
\text { внесения }\end{array}$ & контроль & $\begin{array}{c}\text { после } \\
\text { внесения }\end{array}$ \\
\hline $0-20$ & 2,67 & $-0,06$ & 1,43 & $+0,15$ & 52,6 & $-2,4$ & 30,1 & $+2,2$ \\
\hline $20-40$ & 2,69 & $-0,15$ & 1,44 & $+0,18$ & 51,1 & $-2,06$ & 28,8 & $+2,7$ \\
\hline
\end{tabular}


Таблица 4 - Изменение водно-физических свойств почвы при внесении осадка подготовленных отходов свинокомплекса (2016-2019 гг)

\begin{tabular}{|c|c|c|c|c|c|c|c|c|}
\hline \multirow{2}{*}{$\begin{array}{c}\text { Глубина } \\
\text { горизонта } \\
\text { см }\end{array}$} & \multicolumn{2}{|c|}{ Удельный вес, г/см³ } & \multicolumn{2}{|c|}{ 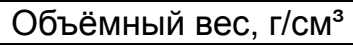 } & \multicolumn{2}{|c|}{ Пористость, \% } & \multicolumn{2}{|c|}{ Влагоёмкость, \% } \\
\hline & контроль & $\begin{array}{c}\text { после } \\
\text { внесения }\end{array}$ & контроль & $\begin{array}{c}\text { после } \\
\text { внесения }\end{array}$ & контроль & $\begin{array}{c}\text { после } \\
\text { внесения }\end{array}$ & контроль & $\begin{array}{c}\text { после } \\
\text { внесения }\end{array}$ \\
\hline $0-20$ & 2,67 & $-0,03$ & 1,43 & $+0,39$ & 52,6 & $-5,1$ & 30,1 & $+10,2$ \\
\hline $20-40$ & 2,69 & $-0,03$ & 1,44 & $+0,48$ & 51,1 & $-5,7$ & 28,8 & $+9,0$ \\
\hline
\end{tabular}

Наблюдалось снижение удельного и увеличение объемного веса почвы. Снизилась пористость почвы в слое от 0 до 40 см в среднем на 2,23\% и 5,4\%,, соответственно, при внесении жидкой фразы и осадка жидких отходов свинокомплекса. Также отмечено увеличение влагоемкости почвы в слое $0-20$ см, на 3,55 \% и 9,6\%, соответственно.

При внесении подготовленных жидких отходов

Таблица 5 - Динамика содержания гумуса, подвижных соединений фосфоора и нитратного азота в почве исследуемого участка (2016-2019 гг)

\begin{tabular}{|c|c|c|c|c|c|c|}
\hline \multirow{2}{*}{$\begin{array}{c}\text { Глубина го- } \\
\text { ризонта см }\end{array}$} & \multicolumn{2}{|c|}{ Гумус,\% } & \multicolumn{2}{|c|}{$\begin{array}{c}\text { Подвижные соединения } \\
\text { фосфоора, мг/кг }\end{array}$} & \multicolumn{2}{c|}{$\begin{array}{c}\text { Нитратный азот, } \\
\text { мг/кг }\end{array}$} \\
\cline { 2 - 7 } & контроль & $\begin{array}{c}\text { после } \\
\text { внесения }\end{array}$ & контроль & $\begin{array}{c}\text { после } \\
\text { внесения }\end{array}$ & контроль & $\begin{array}{c}\text { после } \\
\text { внесения }\end{array}$ \\
\hline $0-20$ & 5,43 & 5,52 & 25,9 & 113,0 & 4,3 & 37,5 \\
\hline $20-40$ & 5,21 & 5,32 & 20,1 & 100,0 & 3,9 & 30,5 \\
\hline
\end{tabular}

Анализ таблицы 5 показал, что на глубине 0-40 см произошло возрастание содержания гумуса в 1,1 раза, подвижных соединений фоосфора - в 4,5 раза, нитратного азота - в 8 раз, что можно объяснить высокой активностью микроорганизмов, которые минерализуют органическое вещество жидких отходов. Кроме того, подготовленные жидкие отходы свинокомплексов благодаря используемой технологии обработки содержат высокое количе-

ство биогенных элементов.

Полученная жидкая фаза подготовленных отходов свинокомплексов использовалась для орошения. Для выявления предполагаемого воздействия на почву была проведена ее ирригационная оценка.

Катионно-анионный состав жидкой фазы представлен в таблице 6.

Таблица 6 - Состав катионов и анионов в жидкой фразе подготовленных отходов свинокомплексов

\begin{tabular}{|c|c|c|c|}
\hline Катионы & Содержание, мг-экв/л & Анионы & Содержание, мг-экв/л \\
\hline $\mathrm{Ca}^{2+}$ & 6,0 & $\mathrm{PO}_{4}^{3-}$ & 3,0 \\
\hline $\mathrm{Mg}^{2+}$ & 5,0 & $\mathrm{SO}^{2-}$ & 7,0 \\
\hline $\mathrm{NH}^{2+}$ & 8,1 & $\mathrm{Cl}^{-}$ & 5,1 \\
\hline $\mathrm{K}^{+}$ & 3,2 & $\mathrm{CO}^{2-}$ & 5,4 \\
\hline $\mathrm{Na}^{+}$ & 5,4 & $\mathrm{Alk}$ & 13.7 \\
\hline
\end{tabular}

Примечание: Alk - щелочность, обусловленная в жидких отходах свинокомплексов, главным образом, анионами органических кислот, а также слабых минеральных кислот и гидроксильными ионами.

Для пригодности жидкой фразы по суммарному содержанию токсичных солей должно соблюдаться условие:

$$
\frac{C \cdot J \cdot H B_{50}}{2000 \cdot(J+P)} \leq 1
$$

где $\mathrm{HB}_{50}$ - наименьшая влагоемкость слоя почвы $0-50 \mathrm{~cm}, \mathrm{Mm}$;
С - токсичные соли, сумма которых составляет 10,5 мг-экв/дм

Р - среднемноголетние используемые растениями атмосферные осадки, мм;

$\mathrm{J}$ - средняя оросительная норма под кукурузу, мм.

Гипотетический состав солей количественно определяют, объединив катионы и анионы по мере возрастания их активности, мг-экв./л (табл. 7);

Таблица 7 - Гипотетический состав образующихся солей

\begin{tabular}{|l|l|l|}
\hline $\mathrm{MgNH}_{4} \mathrm{PO}_{4}-3$ & Остаток $\mathrm{Mg}-1.4$ & $\mathrm{NH}_{4}-5.1$ \\
\hline $\mathrm{CaSO}_{4}-3.0$ & $\mathrm{SO}_{4}-4$ & \\
\hline
\end{tabular}


Продолжение таблицы 7

\begin{tabular}{|l|l|l|}
\hline $\mathrm{CaCl}_{2}{ }^{*}-3.0$ & $\mathrm{Cl}-2.1$ & \\
\hline $\mathrm{MgCl}_{2}{ }^{*}-2,1$ & - & \\
\hline $\mathrm{NH}_{4}$ Alk-5,1 ${ }^{2}$ & Alk-10.0 & \\
\hline $\mathrm{KAlk}_{3} 2$ & Alk-6,8 & \\
\hline $\mathrm{NaAlk}^{*}-5,4$ & - & \\
\hline
\end{tabular}

* - токсичные соли, сумма которых составляет 10,5 мг-экв.

Проведем оценку жидкой фазы с учетом полученных данных содержания токсичных солей, величины атмосферных осадков, влагоемкости почвы и оросительной нормы по формуле (1):

$$
\frac{10,5 \cdot 325 \cdot 180}{2000 \cdot(325+350)}=0,46 \leq 1 \text {. }
$$

Оценка жидкой фразы по опасности натриевого осолонцевания почв проводится по условию:

$$
\frac{\mathrm{Na}^{+}}{\sqrt{\mathrm{Ca}^{2+}+\mathrm{Mg}^{2+}}} \leq 2 \cdot K_{1} \cdot K_{2} \text {, }
$$

где $\mathrm{Na}^{+},, \mathrm{Ca}^{2}+$ и $\mathrm{Mg}^{2+}$ - содержание катионов в жидкой фазе подготовленных отходов свинокомплексов, мг-экв./л; почв;

$K_{1}$ - коэффиицент, равный 2 для карбонатных

$K_{2}$ - коэффиццент, равный

$$
K_{2}=\sqrt{\frac{200}{H B}}=1,1 .
$$

По формуле (2) получаем:

$$
\begin{aligned}
& \frac{5,4}{\sqrt{6,0+5,0}}=1,63 \text {, что меньше, чем } 2 \cdot 2 \cdot \sqrt{\frac{200}{180}}= \\
& =4,4 \text {. }
\end{aligned}
$$

В подготовленной жидкой фразе жидких отходов свинокомплексов соотношение концентраций(мгэкв./л) ионов Мg:Са равно 5:6, то есть меньше 1.

По солевому составу жидкая фаза подготовленных жидких отходов свинокомплексов пригодна для орошения по оценочным формулам (1) и (2) и п.2.6 [10].

По методу И.Н. Антипова-Каратаева и Г.М. Ка-

Таблица 8 - Солевой состав почвы при внесении подготовленной жидкой фразы отходов свинокомплексов, \% к абсолютно сухой почве

\begin{tabular}{|l|c|c|}
\hline \multirow{2}{*}{\multicolumn{2}{|c|}{ Показатель }} & \multicolumn{2}{|c|}{ Слой почвы, см } \\
\cline { 2 - 3 } & \multicolumn{2}{|c|}{$0-40$} \\
\cline { 2 - 3 } & до внесения & после внесения \\
\hline Сухой остаток & 0,0317 & 0,0520 \\
\hline $\mathrm{HCO}_{3}-$ & 0,0048 & 0,0023 \\
\hline $\mathrm{Cl}^{-}$ & 0,0062 & 0,0092 \\
\hline $\mathrm{SO}^{2-}$ & 0,0089 & 0,017 \\
\hline $\mathrm{Ca}^{2+}$ & 0,0028 & 0,0023 \\
\hline $\mathrm{Mg}^{2+}$ & 0,0053 & 0,015 \\
\hline $\mathrm{Na}^{+}$ & 0,0012 & 0,0060 \\
\hline
\end{tabular}

дера дана оценка пригодности жидкой фразы по показателю критического отношения (ПКО) суммы катионов: $\mathrm{Ca}^{2+}$ и $\mathrm{Mg}^{2+}$ к $\mathrm{Na}^{+}$в оросительной жидкости (мг-экв./л) и общей концентрации токсичных солей в воде (г/л):

$$
\Pi K O=\frac{\mathrm{Ca}^{2+}+\mathrm{Mg}^{2+}}{N a^{+} \cdot 0.23 \cdot \mathrm{C}}=\frac{6+5}{5.4 \cdot 0.23 \cdot 2.6}=3.4
$$

Так как вычисленное значение ПКО больше 1, жидкая фаза считается пригодной для орошения [4].

Ввиду отрицательного воздействия магния на свойства почв одним из важных критериев оросительной жидкости является процентное содержание в ней магния. Магний оказывает негативное воздействие на почву, если

$$
\frac{\mathrm{Mg}^{2+} \cdot 100}{\mathrm{Ca}^{2+}+\mathrm{Mg}^{2+}} \geq 50
$$

Подставив значение концентраций ионов в фрормулу (4), получили

$$
\frac{5.0 \cdot 100}{6.0+5.0}=45.5
$$

что менее 50, следовательно, жидкая фраза подготовленных отходов свинокомплексов соответствует критерию для поливной воды по содержанию магния.

По содержанию токсичных солей, по опасности натриевого осолонцевания полученные ирригационные оценки удовлетворяют требованиям орошения.

Важное значение имел также агромелиоративный контроль за водно-солевым режимом почвы исследуемого участка (табл. 8). 
Критерием засоленности почвы является высокий процент в почвенном растворе сухого остатка. Исследуемые образцы, в соответствии с [1], относились к незасоленным, имея сухой остаток 0,0317-0,0520\%, то есть менее 0,3\%. По содержанию иона хлора, значение которого 0,0062-0,0092, почва относится к незасоленным.

Внесение подготовленных жидких отходов свинокомплекса улучшает водно-физические свойства почвы исследуемого участка. В этом большую роль играет отход свеклосахарного производства -дефекационная известь, содержащая в своем составе до 84\% активного $\mathrm{CaO}$, применяемый для реагентной подготовки жидких отходов свинокомплексов.

\section{Результаты и выводы}

Проведенные исследования позволили дать агромелиоративную оценку применения подготовленных жидких отходов свинокомплексов на черноземах Краснодарского края. Использование жидкой фазы и осадка отходов свинокомплекса, прошедших реагентную обработку, привело к повышению гумуса на исследуемом участкев 1,1 раза, подвижных соединений фосфора - в 4,5 раза, нитратного азота - в 8 раз. Для выявления предполагаемого воздействия на почву жидкой фазы была проведена ее ирригационная оценка по суммарному содержанию токсичных солей. По методу И.Н. Антипова-Каратаева и Г.М. Кадера дана оценка пригодности жидкой фразы для орошения. Определено ее воздействие на почву по содержанию магния.

В результате оценки можно сделать следующие выводы:

1.Применение подготовленных жидких отходов свинокомплексов на полях орошения позволит снизить антропогенное воздействие на агроценозы, т.к. отходы содержат высокое количество биогенных элементов, которые благотворно влияют на состав и свойства почвы.

2. Предложенный авторами способ подготовки жидких отходов свинокомплексов с помощью отходов свеклосахарного производства способствует их эффрективной утилизации, значительному сокращению объемов накопителей, а, соответственно, и высвобождению земель, пригодных для сельского хозяйства.

3.При внесении подготовленных отходов происходит увеличение влагоемкости почвы, изменение структуры почвы за счет снижения содержания крупных агрегатов и ее уплотнения.

4.Ирригационная оценка показала экологическую безопасность и пригодность подготовленной жидкой фрракции отходов свинокомплекса для орошения сельскохозяйственных культур.

\section{Список литературы}

1. Астапов, С.В. Мелиоративное почвоведение: практикум / С.В. Астапов.М.:Сельхозгиз.,1958. -369c.- Текст: непосредственный.

2. Бондаренко, А.М. Современные технологии переработки навоза животноводческих предприятий в высококачественные органические удобрения/ А. М. Бондаренко, Л.С. Качанова.Текст:непосредственный// Вестник ВНИИМЖ.2015.-№4(20).-С.135-141.-Рез.англ.-Библиогр.: с. $135-141$ (6 назв.).

3. Волошин, Е.И. Эфрфективность примене- ния органических удобрений в агропромышленном комплексе Красноярского края / Е.И. Волошин.- Текст:непосредственный // Вестник КрасГАУ. - 2016. . №4. -С.138-146. .-Рез.англ.-Библиогр.: с. $138-146$ (15 назв.).

4. Практикум по курсу «Мелиорация почв» / Ф.Р. Зайдельман, Л.Ф. Смирнова, А.П. Шваров, А.С. Никифорова. - М.: Издательство Московского университета, 2002.- 52с.- Текст: непосредственный.

5. Оценка эффеектиности нового органоминерального удобрения на основе свиного навоза /М.А. Куликова, Т.А. Колесникова, Е.А. Грибут [и др.]. - Текст непосредственный // Плодородие, - 2019. - №4(109).- C.49-51.DOI 10.25680/ S19948603.2019.109.16. - Рез.англ.-Библиогр.: C.49-51 (6 назв.).

6. Вероятностное оценивание мелиоративного состояния орошаемого поля при использовании биотехнологии / Я.А. Полторак, Т.И. Сафронова // Научный журнал КубГАУ, [Электронный ресурс].- Краснодар 2016.-№ 07(21), 2016.- С.17781786. - Рез.англ.-Библиогр.: С.1778-1786 (6 назв.).

7. Редина, А.В. Агромелиоративная оценка очищенных животноводческих сточных вод при орошении черноземов южных/ А.В. Редина, Ю.Е. Домашенко, С.М. Васильев. - Текст непосредственный // Известия Оренбургского ГАУ, 2017.-№6(68).С.8-11. - Рез.англ.-Библиогр.: С.8-11 (8 назв.).

8. Суржко, О.А. Экологическая безопасность при переработке и утилизации концентрированных по биогенным элементам жидких отходов промышленных предприятий: монография / О.А. Суржко, М.А. Куликова // Юж.-Рос.гос.техн.ун.-т (НПИ).- Новочеркасск: ЮРГТУ (НПИ), 2011.-140с. - Текст непосредственный.

9. Хаджиди, А.Е Сельскохозяйственный мелиоративный комплекс для устойчивого развития агроландшафтов: монография / А.Е.Хаджиди, Е.В. Кузнецов // Краснодар: изд-во ЭДВИ, 2014. -200 с. -Текст непосредственный.

10. СанПин 2.1.7.573-96. «Гигиенические требования к использованию сточных вод и их осадков для орошения и удобрения».

11. A.Cai, M.Xu, B.Wang, W.Zhang, G.Liang, E.Hou, Y.Luo. Manure acts as a better fertilizer for increasing crop yields than synthetic fertilizer does by improving soil fertility// Soil and Tillage Research. 189 (2019) p.168-175

12. Z.Guo, J.Zha, J.Fan, X.Yang, Y.Yi, X.Han, D.Wang, P.Zhu, X.Peng. Does animal manure application improve soil aggregation? Insights from nine long-term fertilization experiments// Sciens of the Total Environment. 660(2019) p.1029-1037.

13. G.Ye, Y.Lin, Y.Kuzyakov, D.Lio, J.Luo, S.Lindsey, W.Wang, J.Fan, W.Ding. Manure over crop residues increases soil organic matter but decreases microbial necromass relative contribution in upland Ultisols: Results of a 27-year field experiment// Soil Biology and Biochemistry.134(2019) p.15-24.

14. A. Makara, Z. Kowalski. Selection of pig manure management strategies: Case study of Polish farms// Journal of Cleaner Production. 172(2018) p.187-195.

15. O.Arias, S.Vina, M. Uzal, M. Soto. Composting of pig manure and forest green waste amended with industrial sludge// Science of the Total Environmental.586(2017) p.1228-1236 


\title{
AGROMELIORATIVE EVALUATION OF APPLICATION OF PREPARED LIQUID WASTE OF PIG COMPLEXES ON THE BLACK-SOILS OF THE KRASNODAR REGION
}

\author{
Kolesnikova Tatyana A. Senior Lecturer, Platov South-Russian State Polytechnic University (NPI), \\ tanechka-ko1986@yandex.ru \\ Kulikova Marina A., PhD in engineering sciences, associate professor, Platov South-Russian State \\ Polytechnic University (NPI), my7rysyk@mail.ru
}

Over the past five years, the number of pigs in Russia has increased due to the introduction of sanctions on meat imports. The liquid waste of pig farms has a high negative impact, occupying large areas of agricultural land and polluting all areas of the environment. Every year, the anthropogenic load of mankind on agrocenoses is increasing, which adversely affects the condition and quality of the crop. At the same time, the liquid waste of pig farms is a source of valuable components that can improve agro-reclamation indicators of agricultural lands In the territory of the Krasnodar Region there are a large number of sugar manufacturing enterprises, as a result of which large-capacity organic waste is formed: defecation lime, defecate. Defecate sugar production is high in calcium and valuable organic components. Defecation lime of sugar production contains up to $84 \%$ of active $\mathrm{CaO}$, necessary for the preparation of liquid waste from pig farms. The article presents the results of studies on the possibility of the safe use of prepared liquid pig farm waste on chernozems of the Starominsky district of the Krasnodar Territory. An agro-reclamation assessment of the prepared pig liquids liquid reagents was carried out, which showed their high efficiency in minimizing land degradation and restoring the nutrient content in the soil. The authors found a decrease in the salt content in the soil when using prepared liquid waste from pig farms treated with reagents prepared on the basis of beet sugar production waste. The results of studies of the water-physical properties of soils, the content of humus, nitrate nitrogen and mobile phosphorus, the salt composition of soils using liquid waste from pig farms are presented.

Key words: land reclamation assessment, liquid waste of pig farms, reagent treatment, defecation lime, beet pulp, fertility, fertilizers.

1. Astapov S. V. Meliorativnoe pochvovedenie: praktikum. M.:Sel'hozgiz., 1958. -369s.

2. Bondarenko A.M. Sovremennye tekhnologii pererabotki navoza zhivotnovodcheskih predpriyatij $v$ vysokokachestvennye organicheskie udobreniya /A. M. Bondarenko, L.S. Kachanova // Vestnik VNIIMZH , 2015.-№4(20).-s. 135-141.

3. Voloshin E.I. Effektivnost' primeneniya organicheskih udobrenij $v$ agropromyshlennom komplekse Krasnoyarskogo kraya // Vestnik KrasGAU, 2016.- №4. -S.138-146.

4. Zajdel'man F.R. Praktikum po kursu Melioraciya pochv / Zajdel'man F.R., Smirnova L.F., SHvarov A.P., Nikiforova A.S. M.: Izdatel'stvo Moskovskogo universiteta.- 2002. - 52s.

5. Kulikova M.A. Ocenka effektivnosti novogo organomineral'nogo udobreniya na osnove svinogo navoza M.A. Kulikova, T.A. Kolesnikova, E.A. Gribut, O.A. Surzhko, G.E. Merzlaya, E.N. Akanov // Plodorodie, 2019.№4(109).- S.49-51.DOI 10.25680/S19948603.2019.109.16.

6. Poltorak YA.A. Veroyatnostnoe ocenivanie meliorativnogo sostoyaniya oroshaemogo polya pri ispol'zovanii biotekhnologii/ YA.A. Poltorak, T.I. Safronova// Nauchnyj zhurnal KubGAU, [Elektronnyj resurs].Krasnodar 2016. -№ 07(21), 2016.- S.1778-1786.

7. Redina A.V. Agromeliorativnaya ocenka ochishchennyh zhivotnovodcheskih stochnyh vod pri oroshenii chernozemov yuzhnyh/ A.V. Redina, YU.E. Domashenko, S.M. Vasil'ev// Izvestiya Orenburgskogo GAU, 2017.-№6(68).- S.8-11.

8. Surzhko O.A.. Kulikova M.A. Ekologicheskaya bezopasnost' pri pererabotke i utilizacii koncentrirovannyh po biogennym elementam zhidkih othodov promyshlennyh predpriyatij: monografiya/ YUzh.-Ros.gos.tekhn. un.-t (NPI).- Novocherkassk:YURGTU (NPI), 2011.-140s.

9. Hadzhidi A.E., Kuznecov E.V. Sel'skohozyajstvennyj meliorativnyj kompleks dlya ustojchivogo razvitiya agrolandshaftov: monografiya/ Krasnodar:izd-vo EDVI, 2014.-200s.

10. SanPin 2.1.7.573-96. Gigienicheskie trebovaniya $k$ ispol'zovaniyu stochnyh vod $i$ ih osadkov dlya orosheniya i udobreniya.

11. A.Cai, M.Xu, B.Wang, W.Zhang, G.Liang, E.Hou, Y.Luo. Manure acts as a betterfertilizerforincreasing crop yields than synthetic fertilizer does by improving soil fertility/l Soil and Tillage Research. 189 (2019) p.168-175.

12. Z.Guo, J.Zha, J.Fan, X.Yang, Y.Yi, X.Han, D.Wang, P.Zhu, X.Peng. Does animal manure application improve soil aggregation? Insights from nine long-term fertilization experiments// Sciens of the Total Environment. 660(2019) p.1029-1037.

13. G.Ye, Y.Lin, Y.Kuzyakov, D.Lio, J.Luo, S.Lindsey, W.Wang, J.Fan, W.Ding. Manure over crop residues increases soil organic matter but decreases microbial necromass relative contribution in upland Ultisols: Results of a 27-year field experiment// Soil Biology and Biochemistry.134(2019) p.15-24.

14. A. Makara, Z. Kowalski. Selection of pig manure management strategies: Case study of Polish farms// Journal of Cleaner Production. 172(2018) p.187-195.

15. O.Arias, S. Vina, M. Uzal, M. Soto. Composting of pig manure and forest green waste amended with industrial sludge// Science of the Total Environmental.586(2017) p.1228-1236. 


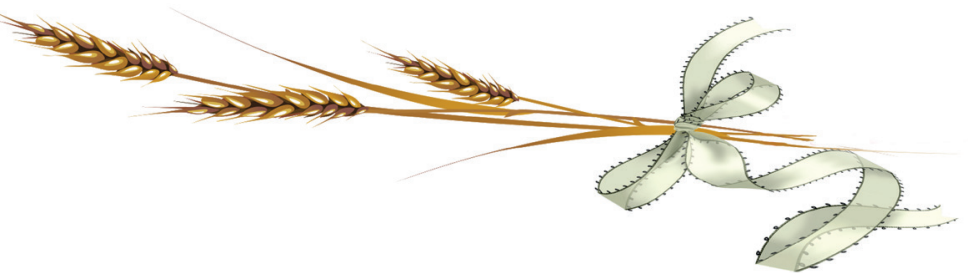

\section{ВЛИЯНИЕ ПРОМОРАЖИВАНИЯ И КРИОГЕНЕЗА НА СВОЙСТВА ПОЧВ}

САВИЧ Виталий Игоревич, д-р с.-х. наук, профрессор кафедры почвоведения, геологии и ландшафртоведения фракультета почвоведения, агрохимии и экологии, savich.mail@gmail.com

БЕЛОПУХОВ Сергей Леонидович, д-р с.-х. наук, професссор, SBelopuhov@rgau-msha.ru

Российский государственный аграрный университет - МСХА имени К.А.Тимирязева

БАЛАБКО Петр Николаевич, д-р биол. наук, профрессор, зав. кафедрой общего земледелия и агроэкологии, Московский государственный университет им. М.B. Ломоносова, agrica@soil.msu.ru

СОРОКИн Андрей Евгеньевич, канд. экон. наук, зав. кафедрой экологии, системы жизнеобеспечения и безопасности жизнедеятельности Московского Авиационного института, kaf614@mail.ru

ДМИТРЕВСКАЯ Инна Ивановна, канд. с.-х. наук, доцент, зав. кафредрой химии, Российский государственный аграрный университет - МСХА имени К.A. Тимирязева, dmitrevskie@mail.ru

Изучено влияние низких температур на изменение процессов ионного обмена в исследуемых почвах, изменение растворимости малорастворимых и труднорастворимых соединений. В качестве объекта были выбраны мерзлотно-таежные почвы, характерные для Якутии. Замораживание почвенных растворов сопровождается увеличением концентрации ионов в незамерзшей части, разрушением алюмосиликатов, изменением прочности связи воды с почвенно-поглощающим комплексом. Это проявляется в инфракрасных спектрах, дериватограммах, а эфрфект был зависим от продолжительности и кратности промораживания. Замерзание верхней части почвенного профиля при наличии многолетней мерзлоты приводит к развитию тиксотропии. Установлено, что интенсивность развития этих процессов отличается для почв разного гранулометрического и минералогического состава, гумусированности, для органических и минеральных горизонтов. Содержание катионов водорастворимых солей в замерзших и незамерзших почвенных растворах мерзлотно-таежных почв

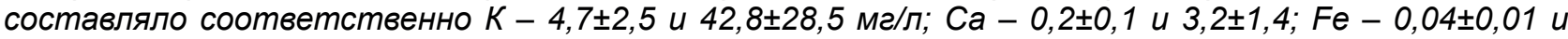
$0,38 \pm 0,03$ м2/л. Эти отличия были характерны для отдельных горизонтов почв. Замерзшая часть раствора менее минерализована, незамерзшая часть содержит большие концентрации элементов. Обсуждается роль многолетней мерзлоты в процессах почвообразования. Низкие температуры профиля и сниженная биологическая активность обуславливают специфику протекания реакций ионного обмена, изменение растворимости осадков, создание водоупора. Эти процессы способствуют аккумуляции веществ в надмерзлотном слое, возникновению новых градиентов и геохимических барьеров в почвенном профиле. Наблюдается локальное развитие почвообразования в слое, образующемся над вечной мерзлотой, при отсутствии промывного водного режима.

Ключевые слова: почва, промораживание, почвенный раствор, криогенез, тиксотропия, инфракрасные спектры, термограммы.

\section{Введение}

Изучению влияния низких температур и криогенеза на почвообразовательные процессы посвящено значительное количество фундаментальных исследований $[1-4,8,9]$. Считается, что частота фазовых переходов вода-лед и количество участвующей в этих переходах влаги - основной показатель криогенных процессов. Интенсивность процессов зависит от глубины и скорости охлаждения почвы, частоты перехода температуры через точку замерзания, от возможности миграции почвенной влаги. Рассматривая эволюцию почв, следует учитывать, что каждая стадия развития почв прерывается криогенными процессами, и в дальнейшем она развивается на смеси почвообразующей породы и прежних горизонтов почв. Следует отметить, что фризическое выветривание почв из-за их пылеватости обусловлено кри- огенным выносом продуктов почвообразования в виде растворов и суспензий за пределы профиля, а также перераспределением продуктов внутри профриля [10]. Однако фризико-химические аспекты данной проблемы изучены в настоящее время недостаточно полно.

Цель исследования - изучить влияние низких температур на изменение процессов ионного обмена в исследуемых почвах, изменение растворимости малорастворимых и труднорастворимых соединений.

\section{Материалы и методы исследований}

В качестве объекта были выбраны мерзлотно-таежные почвы Якутии, которые по составу представляли собой легкий суглинок и глину как подпочву, $\mathrm{pH}=7,7-7,9$;содержание гумуса $2,4-3,3 \%$, $\mathrm{NO}_{3}-10-35 ; \mathrm{P}_{2} \mathrm{O}_{5}-130-140 ; \mathrm{K}_{2} \mathrm{O}-140-300 \mathrm{mr} / \mathrm{\kappa r}$. Контролем служила лугово-черноземная и дерно-

( Савич В. И., Белопухов С. Л., Балабко П. Н., Сорокин А. Е., Дмитревская И. И., 2020 
во-подзолистая почва с известными характеристиками [4,8,13]. Методика исследования состояла в определении содержания катионов и электрического сопротивления в замерзших и незамерзших почвенных растворах (П: $\mathrm{H}_{2} \mathrm{O}=1: 1$ и 1:2), в оценке влияния на состав растворов 5-кратного промораживания и определении при этом изменения свойств почв по данным дериватографии и инфрракрасной спектроскопии в соответствии с ранее предложенными методиками [5,6, 11,12]

Результаты исследований и их обсуждение

Определение содержания катионов в замерзших и незамерзших почвенных растворах. Замерзание почв сопровождается постепенным вымораживанием почвенных растворов, увеличением концентрации растворенных в них соединений, но одновременно и изменением соотношения ионов в незамерзшей части растворов (табл. 1).

Таблица 1 - Содержание катионов в замерзших и незамерзших образцах почвенных растворов, мг/л

\begin{tabular}{|l|c|c|c|c|c|}
\hline Состояние растворов & $\mathrm{K}$ & $\mathrm{Ca}$ & $\mathrm{Fe}$ & $\mathrm{Mg}$ & $(\mathrm{K}+\mathrm{Mg}) / \mathrm{Ca}$ \\
\hline замерзший раствор 1 & $4,7 \pm 2,5$ & $0,2 \pm 0,01$ & $0,04 \pm 0,01$ & $1,8 \pm 0,4$ & 39,5 \\
\hline незамерзший раствор 2 & $42,8 \pm 28,5$ & $3,2 \pm 1,4$ & $0,38 \pm 0,03$ & $7,1 \pm 1,3$ & 15,6 \\
\hline $2 / 1$ & $91,0 \pm 6,3$ & $16,0 \pm 1,7$ & $9,5 \pm 1,2$ & $3,9 \pm 0,7$ & 0,5 \\
\hline
\end{tabular}

Как видно из представленных данных, содержание катионов в незамерзшем растворе выше, чем в замерзшем. Особо следует отметить повышение концентрации калия. При этом зависимость изменения состава растворов при их вымораживании отличается для почв разной степени гумусированности и определенного гранулометрического состава. Так, для разрезов 1, 2 мерзлотно-таежных почв горизонтов $A_{0} A 1$ содержание в замерзших и незамерзших растворах железа и калия, мг/л, и сопротивление составляли соответственно 0,2; 2,$0 ; 41,4 \pm 2,2$ и 0,$3 ; 7,0 ; 149,3 \pm 4,3$. Для разреза 2 $\mathrm{Fe}-0,4$ мг/л, $\mathrm{K}_{2} \mathrm{O}-2,0$; сопротивление - 24,2 $\pm 2,4$; для незамерзшего раствора $\mathrm{Fe}-0,1 \mathrm{мг/л;} \mathrm{K}_{2} \mathrm{O}-$

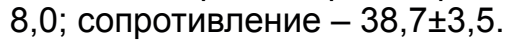

Для минеральных горизонтов этих почв в незамерзшей части растворов было больше К и меньше электрическое сопротивление. В Р-1 горизонт В в замерзшей части раствора содержание $\mathrm{K}_{2} \mathrm{O}$ - 3 мг/л, в незамерзшей - 5,0; сопротивление со-

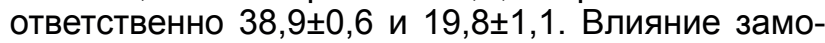
раживания на состав почвенных растворов отличалось для пахотных и подпахотных горизонтов, для горизонтов разной степени гумусированности. В результате исследования установлено, что в пахотном горизонте в замерзшей и незамерзшей

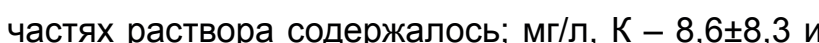

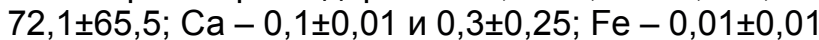

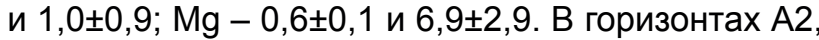
В и ВГ мерзлотно-таежных почв в замерзшей и незамерзшей частях растворов содержание К составляло соответственно $3,5 \pm 1,7$ и 13,6 $\pm 0,9$ мг/л; $\mathrm{Ca}-0,4 \pm 0,2$ и $3,2 \pm 0,4 ; \mathrm{Fe}-0,05 \pm 0,01$ и $0,2 \pm 0,1$;

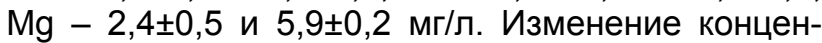
трации ионов в замерзших растворах приводит к их локальной миграции в почвенном профиле. При этом увеличивается содержание не только водорастворимых фрорм соединений, но и более прочносвязанных их фрорм. Так, по полученным данным, при компостировании мерзлотно-таежных почв в условиях оптимальной влажности и после промораживания при $-15{ }^{\circ} \mathrm{C}$ содержание железа, растворимого в $0,05 \mathrm{M} \mathrm{HCl}$, изменилось от 0,46 до 3,9 мг-экв/100 г; железа, растворимого в $0,1 \mathrm{M} \mathrm{HCl}$, от 1,73 до 4,2; а железа, растворимого в $0,15 \mathrm{M} \mathrm{HCl}$, от 3,28 до 4,43. Изменение свойств почв при промораживании зависит от кратности промерзания почв. В проведенных нами исследованиях проводилось 5-кратное промораживание образцов дерново-подзолистой среднесуглинистой почвы и обыкновенного тяжелосуглинистого чернозема (табл.2).

Таблица 2 - Содержание водорастворимых форм Ca, Fe в замерзших и незамерзших почвенных растворах дерново-подзолистой почвы и лугово-черноземной почвы (Ап, мг/л)

\begin{tabular}{|c|c|c|c|c|}
\hline \multirow{2}{*}{$\begin{array}{c}\text { Кратность } \\
\text { промораживания }\end{array}$} & \multicolumn{2}{|c|}{ Чернозем } & \multicolumn{2}{|c|}{ Дерново-подзолистая почва } \\
\cline { 2 - 5 } лед & $\mathrm{Ca}$ & $\mathrm{Fe}$ & $\mathrm{Ca}$ \\
\hline 2 & 58,4 & 0,14 & 0,24 & 16,3 \\
3 & 40,8 & 0,12 & 0,19 & 16,2 \\
4 & 58,3 & 0,18 & 0,30 & 25,7 \\
5 & 58,2 & 0,21 & 0,30 & 15,0 \\
незамерзший рас- & 58,4 & 0,25 & 0,31 & 27,3 \\
твор & 58,5 & 0,25 & 0,25 & \\
\hline
\end{tabular}

Как видно из представленных данных, в незамерзшем растворе в основном больше водорастворимых соединений $\mathrm{Ca}, \mathrm{Fe}$, чем в замерзшей фракции. В соответствии с методикой, после отбора льда при каждом промораживании в почву добавлялось адекватное количество дистиллированной воды, и выход катионов в раствор был дополнительно обусловлен возобновляющей (депо- нирующей) способностью почв. Промораживание почв, увеличивая концентрацию ионов в почвенном растворе, изменяет константы ионного обмена в системе почва-раствор и приводит к разрушению минеральной части почв. Это иллюстрируют полученные нами данные по изменению дериватограмм и инфракрасных спектров предварительно промороженных образцов почв (табл. 3). 
Таблица 3 - Изменение дериватограмм почв при промораживании

\begin{tabular}{|c|l|c|c|c|c|}
\hline № & \multicolumn{1}{|c|}{ Вариант } & ТG, \% & ДТА, ${ }^{0} \mathrm{C}$ & ДТГ, мг/мин & Т, ${ }^{0} \mathrm{C}$ \\
\hline 1 & лугово-черноземная & $-4,1$ & $-23,0$ & $-13,7$ & 938,4 \\
\hline 2 & покровный суглинок & $-7,3$ & $-4,4$ & $-10,6$ & 953,8 \\
\hline 3 & $\begin{array}{l}\text { лугово-черноземная, 5 } \\
\text { раз промороженная }\end{array}$ & $-14,7$ & $-10,8$ & $-25,5$ & 947,7 \\
\hline 4 & $\begin{array}{l}\text { покровный суглинок, 5 } \\
\text { раз промороженный }\end{array}$ & $-7,6$ & $-1,3$ & $-0,5$ & 949,1 \\
\hline
\end{tabular}

Как видно из представленных данных, при промораживании чернозема и покровного суглинка величина ДТА уменьшается, в черноземе потеря веса больше, чем в покровном суглинке, что связано с большей гумусированностью образца. Величина TG при промораживании стала более отрицательной. Скорость потери массы при уве- личении температуры после промораживания в черноземе возросла, в покровном суглинке уменьшилась. Данные инфракрасной спектроскопии исходных и промороженных образцов чернозема и покровного суглинка показали изменение соотношения функциональных групп органического вещества почв при промораживании (табл. 4).

Таблица 4 - Характеристика инфракрасных спектров исходных и промороженных образцов почв

\begin{tabular}{|l|c|c|}
\hline \multicolumn{1}{|c|}{ Образец } & \multicolumn{2}{|c|}{$\mathrm{T, \%}$} \\
\cline { 2 - 3 } & $\approx 1033 \mathrm{~cm}^{-1}$ & $1634 \mathrm{~cm}^{-1}$ \\
\hline лугово-черноземная & 0,98 & 0,7 \\
покровный суглинок & 0,36 & 1,67 \\
лугово-черноземная, 5 раз промороженная & 0,79 & 2,68 \\
покровный суглинок, 5 раз промороженный & 2,73 & 2,64 \\
\hline
\end{tabular}

Как видно из представленных данных, количество карбоксильных фуннциональных групп (1634 $\left.\mathrm{cm}^{-1}\right)$ и спиртовых $\left(1033 \mathrm{~cm}^{-1}\right)$ больше в лугово-черноземной (величина пропускания меньше). Промораживание почв изменило количество и соотношение этих групп. Существенные изменения почвенного поглощающего комплекса при многократном промораживании и оттаивании отмечают и другие авторы. Показано, что под влиянием промерзания и протаивания содержание подвижного свинца уменьшилось [9]. Очевидно, что это может быть обусловлено комплексом изменений свойств почв (изменением pH и Eh, ионной силы, коагуляцией, ионным обменом).

Переуплотнение почв приводит к изменению их водных свойств, показателей газового режима, к трансформации минералов и органического вещества, агрохимических свойств почв. При давлении на ряд минералов возникает электрический ток, и появляется пьезоэлектрический эфффект. В неоднородных по составу породах растворение под давлением осуществляется выборочно (селективно) и при определенных внешних условиях; растворяются лишь некоторые, наиболее растворимые компоненты пород, а другие остаются нерастворимыми. Растворенные в местах повышенного давления компоненты пород переносятся почвенными растворами и переоткладываются на участках с пониженным давлением. Очевидно, что кривизна и силы, возникающие на поверхности раздела жидкой и газовой фраз почвы, концентрация и химический состав растворов оказывают влияние на энергетическое состояние воды. В набухающих почвах на энергетику воды оказывается механическое давление, связанное с ограничен- ным объемом и давлением вышележащих слоев.

Минеральная матрица почв покрыта органической матрицей, что в совокупности представляет органоминеральный гель. Коллоидное состояние вещества рассматривается как обязательная промежуточная стадия в последовательных процессах почвообразования. При этом для большинства почв катионы железа и алюминия существуют в них в основном в виде коллоидных частиц и гидроксиполимеров, заряженных положительно, которые реагируют с отрицательно заряженными коллоидами почв. Взаимодействия происходят и между органическими молекулами почвенных растворов. При этом часто также образуются коллоидные растворы. С учетом изложенного предлагается рассматривать почву как структурированный коагулят со свойствами пептизации, тиксотропии, образования периодических коллоидных структур и т.д. Почва - сложная дисперсная и структурированная коллоидная система, так называемый единый коллоидный каркас (ЕКК).

В работах показано наличие пьезоэлектрического эффректа в почвах [14]. Смещение положительного заряда в противоположную ударной нагрузке сторону наблюдается практически во всех экспериментах. В дерново-подзолистой почве величина пьезоэффректа составляла 40-60 мВ, в южном черноземе - 20-30 мВ, в торфяной почве - 10-15 мB.

Солифрлюкция, тиксотропия, выпучивания и курумообразование - это следствие проявлений полей динамических напряжений между замерзающим верхним слоем и слоем многолетней мерзлоты. Криогенные процессы приводят к перемешиванию горизонтов с породой. При на- 
личии в глубине профиля плотной прослойки (в т.ч. многолетней мерзлоты, горной породы, слоя карбонатов и т.д.) давление верхних слоев на нижележащий слой почвы возрастает, что приводит к возникновению на мерзлоте тиксотропных почв. Тиксотропная мерзлотно-таежная почва, по сравнению с нетиксотропной, характеризовалась большей прочностью связи воды с твердой фазой, что соответствовало гидротермическому эфффекту при более высокой температуре и большей энергии активации реакции гидратации, увеличивающейся при развитии тиксотропии от 46,4 до 53,8 кДж/моль [10]. В процессе замерзания почв наблюдается физическое расширение замерзающей воды, приводящее к расклиниванию тонких водных пленок. В конечном итоге, физическое выветривание обеспечивает увеличение дисперсности почв и пород и повышение химической активности веществ, слагающих эти породы. В момент начала замерзания в твердую фазу выпадают наиболее свободные ионы воды, концентрация раствора повышается. В дальнейшем процесс замерзания протекает при более низких температурах. Когда концентрация раствора повышается до концентрации насыщенного раствора в твердую фазу, начинают выпадать и растворенные вещества.

При большом динамическом воздействии почва теряет прочность и переходит в плывущее состояние. Это обусловлено образованием высокодисперсных, хорошо стабилизированных структур, с образованием структурной сетки, с накоплением на твердых частицах тиксотропных гидроокисей железа, коллоидной кремнекислоты, с электростатическим воздействием разнозаряженных участков коллоидных частиц. При этом процесс образования тиксотропной структуры обратим, он зависит от вязкости системы, плотности, влажности, наличия свободных электролитов и т.д. Способность тонкодисперсных систем под влиянием механических воздействий (таких как встряхивание, размешивание, удар, вибрация, сильное давление) переходить в золь, а затем после прекращения воздействия переходить в гель, называется тиксотропией. При этом способность противостоять этому процессу зависит от состава дисперсных систем.

Коагуляционные структуры почвенных суспензий имеют невысокую прочность, ползучесть, структурную вязкость, а в пастах пластичность. В них тиксотропия выражена в наибольшей степени. Конденсационные структуры характеризуются прочным межчастичным взаимодействием, что связано с удалением из них воды и образованием комплексных соединений водорастворимых органических лигандов и поливалентных катионов ППК (это призматические, ореховатые, столбчатые и столбовидные структуры). Они теряют тиксотропные свойства и приобретают прочность и хрупкость. Кристаллизационные структуры характеризуются преобладанием ковалентных связей и обладают наибольшей механической прочностью. В них происходит необратимое разрушение структур при механическом воздействии на них. Указан- ные структуры, характерные для почв, отличаются различной устойчивостью к механическим воздействиям и различной обратимостью свойств после прекращения воздействия.

В ряде исследований показано, что вибрационные воздействия уменьшают устойчивость почв к тиксотропии. При этом постепенно происходит нарушение связей в почве и размягчение грунта, затем разрушение структурных связей и разжижение грунта. Показателем является уменьшение при динамических нагрузках предела структурной прочности. Возникновение тиксотропных изменений проявляется лишь в том случае, когда глинистых частиц в грунте более 1,5-2\%. Существенное влияние на развитие тиксотропии оказывает минералогический состав почв. Минералы группы монтмориллонита в отличие от группы слюд и каолинита склонны к тиксотропным изменениям. Высокая гидрофильность поверхности глинистых частиц способствует проявлению тиксотропии, которая возрастает с повышением емкости катионного обмена. При вибрационных воздействиях происходит накопление пластических донорных связей, приводящих к разрушению грунта [13].

\section{Заключение}

Многолетняя мерзлота, которая характерна для Якутии, является фрактором почвообразования. Низкие температуры профиля и сниженная биологическая активность обуславливают специфику протекания реакций ионного обмена, изменение растворимости осадков, создание водоупора. Очевидно, что эти процессы способствуют аккумуляции веществ в надмерзлотном слое, возникновению новых градиентов и геохимических барьеров в почвенном профиле. Безусловно, наблюдается локальное развитие почвообразования в надмерзлотном слое при отсутствии промывного типа водного режима. Следует отметить, что на процессы в почве влияют иссушение и промораживание, приводящие к увеличению концентрации и изменению состава почв. Замерзшая часть раствора менее минерализована, незамерзшая часть содержит большие концентрации элементов. Последовательность выпадения солей в осадок следующая: карбонаты, сульфаты и хлориды. Наблюдается возрастание доли $\mathrm{Na}$ и $\mathrm{Cl}$ в оставшемся концентрированном растворе. Вымораживание в растворе приводит к разрушению алюмосиликатов на фроне увеличения доли $\mathrm{CO}_{2}, \mathrm{H}_{2}, \mathrm{O}_{2}$.

\section{Список литературы}

1. Алифанов, В.М. Палеокриогенез и современное почвообразование: автореф. дис... д-ра биол. наук: 03.00.27 / В.М. Алифанов. - М.: МГУ, 1992.

2. Анисимова, Н.П. Гидрохимические исследования криолитозоны Центральной Якутии / Н.П. Анисимова, Н.А. Павлова. - Новосибирск: ГСО, 2014. - 182 c.

3. Горячкин, С.В. Почвенный покров Севера (структура, генезис, экология, эволюция) / С.В. Горячкин. - М.: ГЕОС, 2010. - 414 с.

4. Еловская, Л.Г. Почвы Северной Якутии / Л.Г. Еловская, Е.И. Петрова, Л.В. Тетерина. - Ново- 
сибирск: Наука, 1979. - 303 с.

5. Шнее, Т.В. Изменение физико-химических свойств почвенных коллоидов в зависимости от ионного состава почвенного поглощающего комплекса / Т.В. Шнее, С.Э. Старых, Т.А. Фёдорова, М.Д. Маслова, С.Л. Белопухов, А.А. Шевченко // Плодородие. - 2014. - №3. - С.33-35.

6. Маслова, М.Д., Исследование коллоиднохимических свойств солонцовых почв физико-химическими методами / М.Д. Маслова, Т.В. Шнее, С.Л. Белопухов, Р.Ф. Байбеков // Плодородие. 2014. - №2. - C.41-43.

7. Конищев, В.Н. Формирование состава дисперсных пород в криолитосфере / В.Н. Конищев. Новосибирск: Наука, 1981. - 195 с.

8. Коноровский, А.К. Засоленность и мерзлотность почв Якутии / А.К. Коноровский. - Якутск: ЯНЦ СО АН СССР, 1990. - 43 с.

9. Макеев, О.В. Температурное поле почв. Закономерное развитие и почвообразующая роль / О.В.Макеев,Р.Е.Остроумов.-М.:Наука, 1985.-192с.
10. Соколов, И.А. Почвенный криогенез. Почвообразовательные процессы / И.А. Соколов, Д.Е. Конюшков, Е.М. Наумов, Т.В. Ананко, Т.Е. Якушева - М.: Почвенный ин-т им. В.В. Докучева, 2006. - C. 144-166.

11. Савич, В.И. Инструментальные методы исследования почв, как компонентов агрофитоценозов и экологической системы / В.И. Савич, В.А. Раскатов. - М.: Изд-во РГАУ-МСХА, 2012.- 229 с.

12. Савич, В.И. Физико-химические основы плодородия почв / В.И. Савич. - М.: Изд-во РГАУMCXA, 2013. - 431 c.

13. Савич, В.И. Свойства, процессы, режимы мерзлотно-таежных почв / В.И. Савич, О.И. Худяков, В.А. Черников, В.В. Гукалов, Д.С. Скрябина. - М.: Изд-во РГАУ-МСХА, 2016. - 312 с.

14. Федотов, Т.Н. Электрические свойства почв, как проявление их коллоидной структурированности / Т.Н. Федотов, А.И. Поздняков // Лесной вестник. - 2003. - №1. - С. 69-74.

\section{INFLUENCE OF FROST PENETRATION AND CRYOGENESIS ON SOIL PROPERTIES}

Savich Vitaly I., doctor of agricultural sciences, professor, Russian State Agrarian University-Moscow Timiryazev Agricultural Academy, savich.mail@gmail.com

Belopukhov Sergey L., doctor of agricultural sciences, professor, Russian State Agrarian UniversityMoscow Timiryazev Agricultural Academy, SBelopuhov@rgau-msha.ru

Balabko Peter N., doctor of biological sciences, professor, Lomonosov Moscow State University, agrica@ soil.msu.ru

Sorokin Andrey E., Associate Professor, candidate of economic sciences, Moscow Aviation Institute, kaf614@mail.ru

Dmitrevskaya Inna I., Associate Professor, candidate of agricultural sciences, Russian State Agrarian University-Moscow Timiryazev Agricultural Academy, dmitrevskie@mail.ru

Low temperatures lead to alterations of ion exchange processes in the soil, fallout solubility. As an object, permafrost-taiga soils characteristic of Yakutia were chosen. The freezing of soil solutions is provided with ion densification in unfrozen parts, alumosilicate destruction, change in the bond strengths between water and the soil adsorption complex, infrared spectra, thermograms. Freezing the upper part of the soil profile in the presence of permafrost leads to the development of tixotropy. However, the rate of these processes development differs for the soils of different granulometric and mineralogical content, high humus content, for organic and mineral horizons. At this rate, the water-soluble cation content in frozen and unfrozen soil solutions of cryomorphic-taiga soils was $K-4,7 \pm 2,5$ and $42,8 \pm 28,5 \mathrm{mg} / \mathrm{l} ; \mathrm{Ca}-0,2 \pm 0,1$ and $3,2 \pm 1,4 ; \mathrm{Fe}-0,04 \pm 0,01$ and $0,38 \pm 0,03 \mathrm{mg} / \mathrm{l}$ accordingly. These distinctions were typical for certain soil horizons. Frost penetration of the soils modified their thermograms and infrared spectra. The effect depended on the persistency and frequency of the frost penetration. The frozen part of the solution is less mineralized, the unfrozen part contains large concentrations of elements. The role of permafrost in soil formation is discussed. Low profile temperatures and reduced biological activity determine the specifics of the ion exchange reactions, changes in the solubility of precipitation, the creation of a water seal. These processes contribute to the accumulation of substances in the permafrost layer, the emergence of new gradients and geochemical barriers in the soil profile. There is a local development of soil formation in the layer formed over permafrost, in the absence of washing type of water regime.

Key words: soil, frost penetration, soil solution, cryogenesis, thixotropy, infrared spectra, thermograms.

\section{Literatura}

1.Alifanov, V.M. Paleokriogenez i sovremennoe pochvoobrazovanie: avtoref. dis... d-ra biol. nauk: 03.00.27 IV.M. Alifanov. - M.: MGU, 1992.

2.Anisimova, N.P. Gidrohimicheskie issledovaniya kriolitozony Central'noj YAkutii / N.P. Anisimova, N.A. Pavlova. - Novosibirsk: GSO, 2014. - 182 s.

3. Goryachkin, S. V. Pochvennyj pokrov Severa (struktura, genezis, ekologiya, evolyuciya) / S. V. Goryachkin. - M.: GEOS, 2010. - 414 s.

4.Elovskaya, L.G. Pochvy Severnoj YAkutii / L.G. Elovskaya, E.I. Petrova, L.V. Teterina. - Novosibirsk: Nauka, 1979. - $303 \mathrm{~s}$.

5.SHnee, T.V. Izmenenie fiziko-himicheskih svojstv pochvennyh kolloidov v zavisimosti ot ionnogo sostava 
pochvennogo pogloshchayushchego kompleksa / T.V. SHnee, S.E. Staryh, T.A. Fyodorova, M.D. Maslova, S.L. Belopuhov, A.A. SHevchenko // Plodorodie. - 2014. - №3. - S.33-35.

6.Maslova, M.D., Issledovanie kolloidno-himicheskih svojstv soloncovyh pochv fiziko-himicheskimi metodami / M.D. Maslova, T.V. SHnee, S.L. Belopuhov, R.F. Bajbekov // Plodorodie. - 2014. - №2. - S.41-43.

7.Konishchev, V.N. Formirovanie sostava dispersnyh porod v kriolitosfere / V.N. Konishchev. - Novosibirsk: Nauka, 1981. - $195 \mathrm{~s}$.

8.Konorovskij, A.K. Zasolennost' i merzlotnost' pochv YAkutii / A.K. Konorovskij. - YAkutsk: YANC SO AN SSSR, 1990. - 43 s.

9.Makeev, O.V. Temperaturnoe pole pochv. Zakonomernoe razvitie i pochvoobrazuyushchaya rol' / O.V. Makeev, R.E. Ostroumov. - M.: Nauka, 1985. - 192 s.

10.Sokolov, I.A. Pochvennyj kriogenez. Pochvoobrazovatel'nye processy / I.A. Sokolov, D.E. Konyushkov, E.M. Naumov, T.V. Ananko, T.E. YAkusheva - M.: Pochvennyj in-t im. V.V. Dokucheva, 2006. - S. $144-166$.

11.Savich, V.I. Instrumental'nye metody issledovaniya pochv, kak komponentov agrofitocenozov $i$ ekologicheskoj sistemy / V.I. Savich, V.A. Raskatov. - M.: Izd-vo RGAU-MSKHA, 2012.- 229 s.

12. Savich, V.I. Fiziko-himicheskie osnovy plodorodiya pochv / V.I. Savich. - M.: Izd-vo RGAU-MSKHA, 2013. $-431 \mathrm{~s}$.

13. Savich, V.I. Svojstva, processy, rezhimy merzlotno-taezhnyh pochv / V.I. Savich, O.I. Hudyakov, V.A. CHernikov, V.V. Gukalov, D.S. Skryabina. - M.: Izd-vo RGAU-MSKHA, 2016. - 312 s.

14.Fedotov, T.N. Elektricheskie svojstva pochv, kak proyavlenie ih kolloidnoj strukturirovannosti / T.N. Fedotov, A.I. Pozdnyakov // Lesnoj vestnik. - 2003. - №1. - S. 69-74.

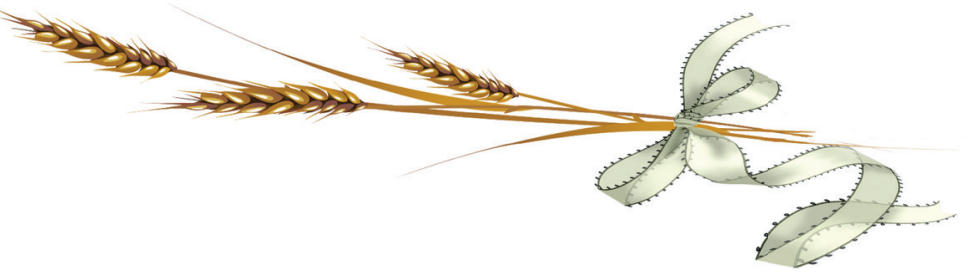

УДК 638.16

DOI 10.36508/RSATU.2020.45.1.010

\section{ВОЗДЕЙСТВИЕ ОТРИЦАТЕЛЬНЫХ ТЕМПЕРАТУР И РАЗНЫХ РЕЖИМОВ ХРАНЕНИЯ НА ОСНОВНОЙ ФЕРМЕНТ МЕДА}

ТУНИкОВ Геннадий Михайлович, д-р с.-х. наук, професссор кафредры частной зоотехнии и биологии, Рязанский государственный агротехнологический университет имени П.А. Костычева

СЕРЕБРЯКОВА Оксана Владимировна, мл. научн.сотрудник, ФГБНУ «Федеральный научный центр пчеловодства», rybnoebee@mail.ru

ЕСЕНКИНА Светлана Николаевна, научн. сотрудник, ФГБНУ «Федеральный научный центр пчеловодства», г. Рыбное, rybnoebee@mail.ru

В статье представлены результаты исследования воздействия отрицательных температур и различных режимов хранения на активность фермента инвертазы в меде натуральном. В связи с тем, что фермент инвертаза имеет огромное значение при исследовании качества меда, целью исследования стало определение степени влияния отрицательных температур и режимов хранения на содержание фермента инвертазы и ее активность. Объектом исследования стал мед натуральный разных сроков и условий хранения. На основании поставленной цели были решены следующие задачи: определены данные по влиянию режимов хранения в условиях отрицательных температур: при $-5-8{ }^{\circ} \mathrm{C}$ (в течение 30 суток и трех месяцев), при $-10^{\circ} \mathrm{C}$ (в течение 30 суток и трех месяцев), при $18^{\circ} \mathrm{C}$ (в течение 30 суток и трех месяцев). Проведена биометрическая обработка данных, полученных в ходе запланированного исследования. Исследования проведены в научно-исследовательской лаборатории ФГБНУ «ФНЦ пчеловодства». Определение активности фрермента инвертазы выполнено по ГОСТ 34232-2017 «Мед. Методы определения активности сахаразы (инвертазы), диастазного числа, нерастворимого вещества». Опытные образцы меда натурального в трех повторностях подвергали влиянию отрицательных температур в различных временных режимах; при $-5-8^{\circ} \mathrm{C}$, при $-10^{\circ} \mathrm{C}$, при $-18^{\circ} \mathrm{C}$ (в течение 30 суток и трех месяцев). Полученные результаты свидетельствуют, что снижение активности в наибольшей степени произошло у образцов, которые хранили в усло-

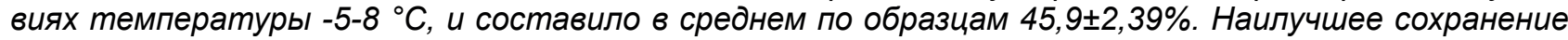
активности наблюдалось у образцов меда, которые хранили при температуре $-18{ }^{\circ} \mathrm{C}-42,1 \pm 3,06 \%$. Результаты свидетельствуют о том, что хранение меда в условиях более глубокой заморозки способствует лучшему сохранению активности фрерментов в его составе.

Ключевые слова: мед, активность инвертазы, отрицательные температуры, условия хранение.

Введение

Мед натуральный - это продукт переработки медоносными пчелами нектара или пади. В процессе данной переработки пчелы обогащают не-

() Туников Г. М., Серебрякова О. В., Есенкина С. Н., 2020 г. 
ктар ферментами и активными веществами, которые, в свою очередь, входят в состав секрета их желез (гипофарингиальной, головной, грудной и других). Продукты, которые собирают пчелы для переработки в мед, чаще всего являются растительными жидкостями. Пчелы собирают эти жидкости при помощи хоботка с дальнейшей переработкой ротовым аппаратом. Изменения, которые происходят в процессе образования меда, на данный момент не до конца изучены. Основной процесс, протекающий при созревании - распад дисахаридов и олигосахаридов на моносахара под действием фермента инвертазы, содержащейся в секрете гипофарингиальных желез. Наряду с разложением сахаров происходит испарение воды и синтез других важных веществ. Увеличение концентрации органических кислот, минеральных веществ и зольных элементов в результате испарения влаги приводит к фоормированию определенной буферной системы.

\section{Теоретические основы изучения активности ферментов меда}

Значение ферментной группы в составе меда натурального трудно переоценить. Ведь абсолютно все ферменты меда принимают активное участие в биохимических реакция, протекающих в нем.

В настоящее время установлено, что в измеримом количестве мед содержит следующие ферменты - инвертазу, диастазу, каталазу, глюкооксидазу. Также мед содержит многие другие энзимы - кислую фоссфотазу, пероксидазу, эстеразу и другие [1]. Количество их варьирует и имеет не измеримые пределы, и зависит от ботанического происхождения меда, однако даже в таких количествах они регулируют определенные биохимические процессы. Присутствие инвертазы в организме самих пчел и в меде впервые было установлено Эрленмейлером в 1847 году. Во многих литературных источниках отмечено, что инвертаза попадает в мед главным образом с секретом гипафарингиальных желез пчел, но последние исследования «ФНЦ пчеловодства» свидетельствуют о взаимосвязи активности фермента инвертазы, в основном, с его ботаническим происхождением. Данный фермент играет основополагающую роль как при биохимических процессах, совершающихся при переработке нектара в мед, так и в изменениях углеводов и сахаров при его хранении. В своей основе роль фермента инвертазы главным образом сводится к гидролизу сахарозы до моносахаридов - глюкозы и фруктозы, а также к образованию с помощью процесса переноса групп сахаров более высокого порядка.

Химическая реакция гидролиза сахарозы под действием фермента инвертазы представлена на рисунке 1.

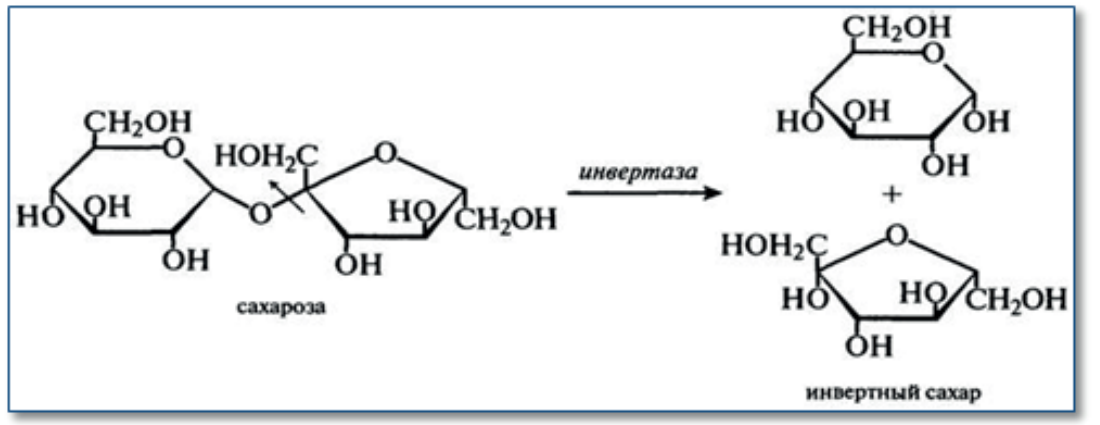

Рис. 1 - Химическая реакция гидролиза сахарозы под действием фермента инвертазы

Помимо сахарозы энзим инвертаза гидролизует и другие олиго- и дисахариды. Исключением является лактоза, причина заключается в том, что между составляющими ее моносахаридами существуют $\beta$-связи, однако инвертаза расщепляет только а-связи. Также установлено, что инвертаза в меде молекулярно состоит из нескольких энзимов (от 6 до 17), которые являются а-глюкозидазами с удельной молекулярной массой около 51000 . Благоприятными условиями для действия фермента на сахарозу считаются параметры: pH 6,0-6,2; температура - 25-30 ${ }^{\circ} \mathrm{C}$; концентрация субстрата - 10-20\% [1].

Кроме вышеназванных энзимов, в меде присутствует каталаза. Ее действие направлено на разложение перекиси водорода на свободный кислород и воду. Попадание каталазы в мед с достоверностью не выяснено, однако установлено что этот фермент выделяется ректальными железами пчел, а значит, попасть в мед в процессе его образования он не может. Преобладает мне- ние, что он попадает в мед из пыльцевых зерен, а также дрожжей. В процессе брожения меда, происходящем под воздействием микроорганизмов, каталазная активность, как и диастазная, резко возрастает. Каталазную активность принято выражать в миллилитрах выделенного кислорода или в миллиграммах разложенной перекиси водорода. Установлено, что падевый мед имеет более высокую каталазную активность, так как содержит больше микроорганизмов.

В составе меда также содержится и фермент глюкозооксидаза. Благодаря присутствию этого энзима мед имеет противомикробное действие. А именно, под действием глюкозооксидазы происходит выделение перекиси водорода, которая разлагается с освобождением активного кислорода, действующего антибактериально. Глюкозооксидаза пчелиного меда весьма чувствительна к дневному свету, и соответственно, к нагреванию. Фосфатазы принадлежат к группе фрерментов, которые гидрализуют сложные эфиры фоссфорной 
кислоты и попадают в мед только из пыльцы и нектара.

Пчелиный мед содержит в небольшом количестве эстеразу, активность этого фермента тесно связана с природой его субстрата. Биохимическое действие фермента проявляется более сильно на сложных эфирах с короткой углеродной цепью кислоты, образующей сложные эфиры.

Некоторые виды и сорта медов содержат и пероксидазу, полифенолоксидазу и протеолитические ферменты. Активность этих фрерментов, однако, очень низкая, и чаще не подлежат измерению. В завершении описания ферментной группы меда следует отметить, что основными энзимами содержащимися в самом большом количестве, являются инвертаза и диастаза. Значение показателей последнего отражены в нормативной документации по контролю качества меда натурального [2].

В последние десятилетия проблема рационального и экологически чистого питания волнует многие науки медицинского направления. Ведущие нутрициологи, диетологи считают, что данный вопрос можно решить лишь путем составления сбалансированного рациона, а также использовать лишь экологически чистые продукты питания. Продукты пчеловодства в своей основе могут претендовать на статус продуктов питания с особенно выгодными для организма характеристиками.

Постоянный недостаток ферментов, поступающих с пищей, является распространенной проблемой в питании человека. Это происходит потому, что основу наших потребляемых блюд составляют приготовленные или обработанные ингредиенты. Кулинарное приготовление пищевых продуктов при $118{ }^{\circ} \mathrm{C}$ окончательно уничтожает все живые ферменты; их не содержат также и полуфабрикаты. Тепловая обработка пищи не способствует сохранению питательных веществ. Пастеризация, стерилизация, многократное размораживание и замораживание, обработка в микроволновой печи инактивируют ферменты, нарушая и изменяя их структуру.

Мед натуральный является одним из последних неприготовленных продуктов питания, который обладает богатым составом, терапевтическими и функциональными свойствами. Хоть и установлено, что мед нельзя считать источником азотистых веществ, однако все белки меда (а их около 1\%) представлены именно ферментной группой. Мед также может являться дополнительным источником ферментов в ежедневном рационе. Так, если потреблять рекомендованные 100 г меда в день, в среднем, то можно получать $10-12 \%$ от необходимой нормы фрерментов в сутки.

Несмотря на то, что ряд энзимов меда обнаруживают в крайне малых количествах, они играют важную роль в его биохимических процессах. Во-первых, эти ферменты способствуют распаду сложных веществ до легкоусвояемых организмом человека. Во-вторых, чем дольше они сохраняют свою активность, тем качественнее хранение меда в производственных и бытовых условиях.
Важность темы фрерментного состава пищевых продуктов нельзя переоценить, так как они важны для пищеварения, предупреждения заболеваний обмена веществ организма и многого другого. При употреблении свежей не обработанной продукции питательные вещества попадают в кровь и разрушают белковую структуру патогенных организмов, которые могут появляться при воспалениях. На основании чего мед натуральный, а именно ферменты в его составе, весьма полезны при воспалениях, отеках, гиперемии различного характера, острой боли. Еще раз следует отметить тот фракт, что усвоение углеводов (фруктозы и глюкозы) без процесса их ферментации важно для людей с патологическим или биологическим снижением активности ферментативных процессов желудочнокишечного тракта. Это могут быть лица пожилого возраста и дети. И соответственно, сами ферменты меда, попадая в ЖКТ, также переваривают вещества пищи в кишечном соке.

Перекись водорода, которая содержится в меде, играет роль ингибитора бактериальной фолоры. Сама она в свою очередь образуется при окислении моносахарида - глюкозы, под действием фермента глоточной железы пчел - глюкозооксидазы. Однако, энзим каталаза оказывает разрушающее воздействие на перекись водорода. Именно этим объясняется тот факт, что при длительном хранении меда активность ферментов естественно снижается и бактерицидное свойство возрастает [3].

Лабильность - одно из важных свойств ферментов, которое обеспечивается их белковой природой. Оно заключается в способности изменять свою активность в зависимости от разнообразных факторов окружающей и собственно внутренней среды. При изучении влияния какого-либо фактора на активность фрермента инвертазы и скорости инверсии сложных углеводов в меде все прочие факторы должны оставаться неизменными и по возможности иметь оптимальные значения. Установлено, что активность инверсии сахарозы зависит главным образом от температуры среды, в условиях которой происходит гидролитическая реакция. Для меда натурального оптимальной температурой является $36-38{ }^{\circ} \mathrm{C}$, а для нектара - 40-48 ${ }^{\circ} \mathrm{C}$. Если температура повышается на несколько градусов от оптимального значения, то происходит инактивация фрермента инвертазы. Причем зависит это не только от уровня температуры, но и от продолжительности ее воздействия.

Если же температура опускается до отрицательных значений, то активность фермента инвертазы приостанавливается, и показатель значения активности снижается на несколько единиц. Это объясняется снижением скорости движения молекул субстрата и соответственно самого фермента. Следует отметить, что при обратном повышении температуры до оптимального значения активность фермента восстанавливается [6]. Иными словами, низкие температуры не инактивируют инвертазу и не переводят белки в коагулированное состояние. М. Гонне отмечал, что при хранении меда в условиях низких и отрицательных темпе- 
ратур катализаторы понижают энергию активации реакции гидролиза в 2-3 раза. Степень активности фермента инвертазы, по мере падения температуры, бывает различной у разных медов, это объясняется нарушением равновесия в циклах взаимосвязанных биохимических реакций в меду [7].

\section{Объекты и методы исследования}

В связи с тем, что фермент инвертаза имеет огромное значение при исследовании качества меда, целью исследования стало определение степени влияния отрицательных температур на активность фермента инвертазы в меде. Объектом исследования стал мед натуральный разных сроков и условий хранения. Для достижения поставленной цели были решены следующие задачи:

1) заготовка образцов и отбор проб меда для проведения исследования;

2) исследование заготовленных образцов на соответствие требованиям государственного стандарта на мед натуральный - ГОСТ 197922017 Мед натуральный. Технические условия;

3) хранение отобранных опытных проб меда в условиях отрицательных температурных режимов при $-5-8^{\circ} \mathrm{C}, п р и-10^{\circ} \mathrm{C}$; при $-18^{\circ} \mathrm{C}$ (в течение 30 суток и трех месяцев);

4) хранение отобранных контрольных проб меда в рекомендованных оптимальных условиях при температуре $15-16{ }^{\circ} \mathrm{C}$ (в течение 30 суток и трех месяцев);

5) получение экспериментальных данных по влиянию на мед режимов хранения в условиях отрицательных температур в сравнении с контроль- ными результатами;

6) проведение биометрической обработки данных, полученных в ходе запланированного исследования.

Исследования проведены в лаборатории ФГБНУ «ФНЦ пчеловодства». Определение активности фермента инвертазы и инвертазного числа выполнено по ГОСТ 34232- 2017 «Мед. Методы определения активности сахаразы (инвертазы), диастазного числа, нерастворимого вещества». Исследуемые опытные образцы меда в трех повторностях помещали в стеклянные прозрачные емкости по 250 мл. и подвергали влиянию отрицательных температур в различных временных режимах: при $-5-8^{\circ} \mathrm{C}$, при $-10^{\circ} \mathrm{C}$, при $-18^{\circ} \mathrm{C}$ (в течение 30 суток и трех месяцев). Хранение контрольных образцов меда также осуществлялось в трех повторностях, помещенных в стеклянные прозрачные емкости по 250 мл. в регулируемых условиях при температуре $15-16{ }^{\circ} \mathrm{C}$ (в течение 30 суток и трех месяцев).

\section{Результаты исследования}

Bсе отобранные исследуемые образцы меда соответствовали требованиям государственного стандарта по основным фризико-химическим показателям согласно ГОСТ 19792-2017 Мед натуральный. Технические условия.

Результаты исследования влияния температуры $-5-8{ }^{\circ} \mathrm{C}$ на активность инвертазы в меде в течение определенного периода времени представлены в таблице 1.

Таблица 1 - Влияние температуры хранения -5-8 ${ }^{\circ} \mathrm{C}$ на активность фермента инвертазы в меде $(\mathrm{M} \pm \mathrm{m})$

\begin{tabular}{|c|c|c|c|c|c|c|c|c|c|}
\hline \multirow{2}{*}{$\begin{array}{l}\text { Наимено- } \\
\text { вание } \\
\text { образца }\end{array}$} & \multirow{2}{*}{$\begin{array}{c}\text { Контроль } \\
\text { Акт. инв. } \\
(\text { ед/г) } \\
\end{array}$} & \multicolumn{2}{|c|}{$\begin{array}{c}\text { Контроль } \\
\text { через } 1 \mathrm{mec} \\
\end{array}$} & \multicolumn{2}{|c|}{$\begin{array}{c}\text { Опыт } \\
\text { через } 1 \mathrm{mec} \\
\end{array}$} & \multicolumn{2}{|c|}{$\begin{array}{c}\text { Контроль } \\
\text { через } 3 \text { мес } \\
\end{array}$} & \multicolumn{2}{|c|}{$\begin{array}{c}\text { Опыт } \\
\text { через } 3 \text { мес }\end{array}$} \\
\hline & & $\begin{array}{c}\text { Акт.инв. } \\
\text { (ед/г) }\end{array}$ & $\begin{array}{l}\text { \% от } \\
\text { исх. }\end{array}$ & $\begin{array}{c}\text { Акт.инв. } \\
\text { (ед/г) }\end{array}$ & $\begin{array}{l}\text { \% от } \\
\text { исх. }\end{array}$ & $\begin{array}{c}\text { Акт.инв. } \\
\text { (ед/г) }\end{array}$ & $\begin{array}{l}\text { \% от } \\
\text { исх. }\end{array}$ & $\begin{array}{c}\text { Акт.инв. } \\
(\text { ед/г) }\end{array}$ & $\begin{array}{l}\text { \% от } \\
\text { исх. }\end{array}$ \\
\hline 1 & $64,7 \pm 0,06$ & $\begin{array}{c}59,4 \pm \\
0,12\end{array}$ & 8,19 & $\begin{array}{c}60,7 \pm \\
0,47\end{array}$ & 6,18 & $\begin{array}{c}40,9 \pm \\
0,55\end{array}$ & 36,8 & $\begin{array}{c}39,7 \pm \\
0,12\end{array}$ & 38,6 \\
\hline 2 & $68,1 \pm 0,03$ & $\begin{array}{c}52,7 \pm \\
0,07\end{array}$ & 22,6 & $\begin{array}{c}52,4 \pm \\
0,07\end{array}$ & 23,1 & $\begin{array}{c}36,9 \pm \\
0,12\end{array}$ & 45,8 & $\begin{array}{c}35,1 \pm \\
0,18\end{array}$ & 48,5 \\
\hline 3 & $61,7 \pm 0,06$ & $\begin{array}{c}51,7 \pm \\
0,12\end{array}$ & 16,2 & $\begin{array}{c}50,9 \pm \\
0,12\end{array}$ & 17,5 & $\begin{array}{c}32,7 \pm \\
0,07\end{array}$ & 47 & $\begin{array}{c}29,9 \pm \\
0,13\end{array}$ & 51,5 \\
\hline 4 & $42,4 \pm 0,03$ & $\begin{array}{c}36,2 \pm \\
0,09\end{array}$ & 14,6 & $\begin{array}{c}35,9 \pm \\
0,03\end{array}$ & 15,3 & $\begin{array}{c}22,5 \pm \\
0,03\end{array}$ & 46,9 & $\begin{array}{c}21,8 \pm \\
0,13\end{array}$ & 48,6 \\
\hline 5 & $33,7 \pm 0,07$ & $\begin{array}{c}25,0 \pm \\
0,12\end{array}$ & 25,8 & $\begin{array}{c}20,4 \pm \\
0,07\end{array}$ & 39,5 & $\begin{array}{c}24,3 \pm \\
0,07\end{array}$ & 27,9 & $\begin{array}{c}19,5 \pm \\
0,01\end{array}$ & 42,1 \\
\hline
\end{tabular}

Как видно из таблицы 1, активность фермента инвертазы при хранении меда в условиях отрицательных температур замедляется. Снижение активности в процентном отношении у всех контрольных образцов через месяц в среднем составило $17,5 \pm 3,09 \%$ (пределы колебаний 8,19$25,8 \%$ ). Снижение значений показателя активности у опытных образцов через месяц в среднем

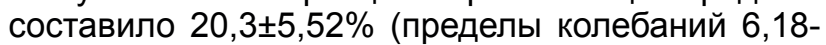
$39,5 \%$ ). Разница между контрольными и опытными образцами не превышала 4,6 ед/г.
Активность у контрольных образцов через 3

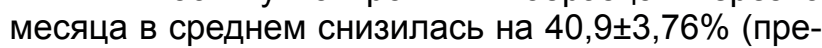
делы колебаний 27,9-47,0\%), тогда как у опытных образцов снижение активности через 3 месяца со-

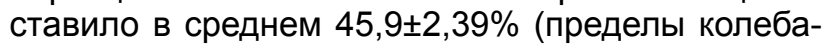
ний 38,6-51,5\%). Разница между контрольными и опытными образцами не превысила 4,8 ед/г.

Результаты исследования влияния температуры $-10^{\circ} \mathrm{C}$ на активность инвертазы в меде в течение определенного периода времени представлены в таблице 2. 
Таблица - 2 Влияние температуры хранения $-10^{\circ} \mathrm{C}$ на активность фермента инвертазы в меде $(\mathrm{M} \pm \mathrm{m})$

\begin{tabular}{|c|c|c|c|c|c|c|c|c|c|}
\hline \multirow{2}{*}{$\begin{array}{l}\text { Наиме- } \\
\text { нование } \\
\text { образца }\end{array}$} & \multirow{2}{*}{$\begin{array}{c}\text { Контроль } \\
\text { Акт. инв. } \\
(е д / г)\end{array}$} & \multicolumn{2}{|c|}{$\begin{array}{c}\text { Контроль } \\
\text { через } 1 \mathrm{mec}\end{array}$} & \multicolumn{2}{|c|}{$\begin{array}{c}\text { Опыт } \\
\text { через } 1 \text { мес }\end{array}$} & \multicolumn{2}{|c|}{$\begin{array}{c}\text { Контроль } \\
\text { через } 3 \text { мес }\end{array}$} & \multicolumn{2}{|c|}{$\begin{array}{c}\text { Опыт } \\
\text { через } 3 \text { мес } \\
\end{array}$} \\
\hline & & $\begin{array}{c}\text { Акт.инв. } \\
\text { (ед/г) }\end{array}$ & $\begin{array}{l}\text { \% Oт } \\
\text { ucx. }\end{array}$ & $\begin{array}{c}\text { Акт.инв. } \\
(\text { ед/г) }\end{array}$ & $\begin{array}{l}\text { \% от } \\
\text { исх. }\end{array}$ & $\begin{array}{c}\text { Акт.инв. } \\
\text { (ед/г) }\end{array}$ & $\begin{array}{l}\text { \% от } \\
\text { исх. }\end{array}$ & $\begin{array}{c}\text { Акт.инв. } \\
\text { (ед/г) }\end{array}$ & $\begin{array}{l}\text { \% от } \\
\text { исх. }\end{array}$ \\
\hline 1 & $46,1 \pm 0,20$ & $\begin{array}{c}45,2 \pm \\
0,13\end{array}$ & 1,9 & $\begin{array}{c}44,5 \pm \\
0,12\end{array}$ & 3,5 & $36,4 \pm 0,33$ & 21,0 & $28,5 \pm 0,24$ & 38,2 \\
\hline 2 & $68,1 \pm 0,03$ & $\begin{array}{l}52,7 \pm \\
0,07\end{array}$ & 22,6 & $\begin{array}{c}57,9 \pm \\
0,24 \\
\end{array}$ & 15,0 & $36,9 \pm 0,12$ & 45,8 & $28,1 \pm 0,18$ & 58,7 \\
\hline 3 & $68,1 \pm 0,03$ & $\begin{array}{c}51,7 \pm \\
0,12\end{array}$ & 16,2 & $\begin{array}{c}53,7 \pm \\
0,13\end{array}$ & 13,0 & $32,7 \pm 0,07$ & 47 & $28,5 \pm 0,38$ & 53,8 \\
\hline 4 & $42,4 \pm 0,03$ & $\begin{array}{c}36,2 \pm \\
0,09\end{array}$ & 14,6 & $\begin{array}{c}40,6 \pm \\
0,13\end{array}$ & 4,3 & $22,5 \pm 0,03$ & 46,9 & $23,1 \pm 0,18$ & 45,5 \\
\hline 5 & $33,7 \pm 0,07$ & $\begin{array}{l}25,0 \pm \\
0,12 \\
\end{array}$ & 25,8 & $\begin{array}{c}21,0 \pm \\
0,07\end{array}$ & 37,7 & $24,3 \pm 0,07$ & 27,9 & $22,7 \pm 0,19$ & 32,6 \\
\hline
\end{tabular}

На основании результатов, представленных в таблице 2, можно отметить, что снижение активности в процентном отношении у всех контрольных образцов через месяц в среднем составило $16,2 \pm 4,12 \%$ (пределы колебаний 1,9-25,8\%). Снижение значений показателя активности у опытных образцов через месяц в среднем составило $14,7 \pm 6,19 \%$ (пределы колебаний 3,51-37,7\%). Разница между контрольными и опытными образцами не превышала 5,2 ед/г.

Активность у контрольных образцов через 3 месяца в среднем снизилась на $37,7 \pm 5,53 \%$ (пределы колебаний 21,0-47,0\%), тогда как у опытных образцов снижение активности через 3 месяца составило в среднем 45,8 $4,81 \%$ (пределы колебаний 32,6-58,7\%). Разница между контрольными и опытными образцами не превысила 8,8 ед/г.

Результаты исследования влияния температуры $-18^{\circ} \mathrm{C}$ на активность инвертазы в мед в течение определенного периода времени представлены в таблице 3.

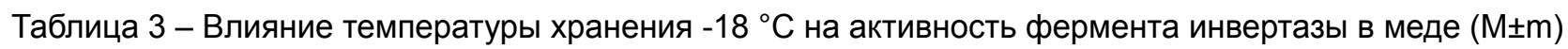

\begin{tabular}{|c|c|c|c|c|c|c|c|c|c|}
\hline \multirow{2}{*}{$\begin{array}{l}\text { Наиме- } \\
\text { нование } \\
\text { образца }\end{array}$} & \multirow{2}{*}{$\begin{array}{c}\text { Контроль } \\
\text { Акт. инв. } \\
(\text { ед/г) }\end{array}$} & \multicolumn{2}{|c|}{$\begin{array}{c}\text { Контроль } \\
\text { через } 1 \mathrm{мес}\end{array}$} & \multicolumn{2}{|c|}{$\begin{array}{c}\text { Опыт } \\
\text { через } 1 \mathrm{mec}\end{array}$} & \multicolumn{2}{|c|}{$\begin{array}{c}\text { Контроль } \\
\text { через } 3 \text { мес }\end{array}$} & \multicolumn{2}{|c|}{$\begin{array}{c}\text { Опыт } \\
\text { через } 3 \text { мес }\end{array}$} \\
\hline & & $\begin{array}{c}\text { Акт.инв. } \\
\text { (ед/г) }\end{array}$ & $\begin{array}{l}\text { \% OT } \\
\text { исX. }\end{array}$ & $\begin{array}{c}\text { Акт.инв. } \\
\text { (ед/г) }\end{array}$ & $\begin{array}{l}\text { \% от } \\
\text { исх. }\end{array}$ & $\begin{array}{c}\text { Акт.инв. } \\
\text { (ед/г) }\end{array}$ & $\begin{array}{l}\text { \% от } \\
\text { исх. }\end{array}$ & $\begin{array}{c}\text { Акт.инв. } \\
\text { (ед/г) }\end{array}$ & $\begin{array}{l}\text { \% от } \\
\text { исх. }\end{array}$ \\
\hline 1 & $39,3 \pm 0,01$ & $\begin{array}{c}37,0 \pm \\
0,17\end{array}$ & 5,9 & $\begin{array}{c}34,6 \pm \\
0,12\end{array}$ & 7,4 & $29,9 \pm 0,03$ & 23,9 & $23,8 \pm 0,33$ & 39,4 \\
\hline 2 & $68,1 \pm 0,03$ & $\begin{array}{c}52,7 \pm \\
0,07\end{array}$ & 22,6 & $\begin{array}{c}46,6 \pm \\
0,18\end{array}$ & 31,6 & $29,9 \pm 0,03$ & 45,8 & $36,9 \pm 0,12$ & 45,8 \\
\hline 3 & $61,7 \pm 0,06$ & $\begin{array}{c}51,7 \pm \\
0,12 \\
\end{array}$ & 16,2 & $\begin{array}{c}53,6 \pm \\
0,21 \\
\end{array}$ & 13,1 & $32,7 \pm 0,07$ & 47 & $32,7 \pm 0,07$ & 47,0 \\
\hline 4 & $42,4 \pm 0,03$ & $\begin{array}{c}36,2 \pm \\
0,09\end{array}$ & 14,6 & $\begin{array}{c}34,3 \pm \\
0,07\end{array}$ & 18,9 & $22,5 \pm 0,03$ & 46,9 & $22,5 \pm 0,03$ & 46,9 \\
\hline 5 & $33,7 \pm 0,07$ & $\begin{array}{c}25,0 \pm \\
0,12\end{array}$ & 25,8 & $\begin{array}{c}21,2 \pm \\
0,07\end{array}$ & 37,1 & $24,3 \pm 0,07$ & 27,9 & $23,2 \pm 0,09$ & 31,2 \\
\hline
\end{tabular}

Из таблицы 3 видно, что снижение активности в процентном отношении у всех контрольных образцов через месяц в среднем составило 17,0 $33,45 \%$ (пределы колебаний 5,9-25,8\%). Снижение значений показателя активности у опытных образцов через месяц в среднем составило 21,6 $\pm 5,57 \%$ (пределы колебаний 7,4-37,1\%). Разница между контрольными и опытными образцами не превышала 5,6 ед/г.

Активность у контрольных образцов через 3 месяца в среднем снизилась на $38,3 \pm 5,11 \%$ (пределы колебаний 23,9-46,9\%), тогда как у опытных образцов снижение активности через 3 месяца со- ставило в среднем 42,1士3,06\% (пределы колебаний 31,2-46,9\%). Разница между контрольными и опытными образцами не превысила 6,1 ед/г.

\section{Выводы}

На основании полученных результатов можно сделать следующие выводы: снижение активности фермента инвертазы в наибольшей степени произошло у образцов, которые хранили в условиях температуры $-5-8^{\circ} \mathrm{C}$, и составило в среднем $45,9 \pm 2,39 \%$. Наилучшее сохранение активности наблюдалось у образцов меда, которые хранили при температуре $-18{ }^{\circ} \mathrm{C}-42,1 \pm 3,06 \%$. Полученные результаты свидетельствуют о том, что хранение 
меда в условиях более глубокой заморозки способствует лучшему сохранению активности ферментов в его составе. Такой мед остается свежим более длительное время, а значит, может использоваться по назначению.

\section{Список литературы}

1.Савина, О.В. Сравнительная оценка качества медовых композиций с исполь-зованием продуктов пчеловодства рязанских и коломенских производителей/ О.В. Савина, Д.С. Зверев //Вестник Рязанского государственного агротехнологического университета им. П.А. Костычева.- 2017. -№ 4 (36).- C. 69-77.

2. Хельмут, Х. Все о меде: Обработка меда / X. Хорн, К. Люлльман. - М.: Астрель, 2011. - 316 с.

3. Бурмистрова, Л. А. О безопасности мёда на
Российском рынке / Л. А. Бурмистрова, М.Н.Харитонова // Пчеловодство. - 2017. - № 6. - С. 50-51. 4. Ватолин, Д. О. О меде, и не только о нем / Д. О. Ватолин // Наука и жизнь. - 2008. - № 11. - С. 56-59.

5. ГОСТ 34232 - 2017 «Мед. Методы определения активности сахаразы (инвертазы), диастазного числа, нерастворимого вещества». М.: Стандартинформ, 2008. 11 с.

6. Чепурной, И. П. Экспертиза качества меда / И. П. Чепурной. - Ставрополь.: «Кавказский край», 2000. - 112 с.

7. Шкендеров, С. Пчелиные продукты / С. Шкендеров, Ц. Иванов. - Софрия.: ЗЕМИЗДАТ, 1985. -223 c.

8. Бернхард, С. Структура и функция фрерментов / С. Бернхард. - М.: «МИР», 1971. - 330 с.

\section{THE IFLUENCE OF NEGATIVE TEMPERATURES AND DIFFERENT STORAGE MODES ON THE MAIN HONEY ENZYME}

Tunikov, Gennady M., doctor of agricultural Sciences, Professor of the Department of private animal science and biology, Ryazan state agrotechnological University named after P. A. Kostychev, Ryazan

Serebryakova Oksana V., Junior researcher of the fgbi "Federal research center of bee», rybnoebee@ mail.ru

Esenkina Svetlana N., researcher, fsbi "Federal scientific center of beekeeping», rybnoebee@mail.ru

The article presents the results of a study of the influence of negative temperatures and different storage modes on the activity of the invertase enzyme in natural honey. Due to the fact that the invertase enzyme is of great importance in the study of honey quality, the purpose of the study was to determine the degree of influence of negative temperatures and storage modes on the content of the invertase enzyme and its activity. The object of the study was honey of different terms and conditions of storage. Based on this goal, the following tasks were solved: data on the influence of storage modes at law temperatures were determined: at-5-8 ${ }^{\circ} \mathrm{C}$ (for 30 days and 3 months), at $-10^{\circ} \mathrm{C}$ (for 30 days and 3 months), at $-18^{\circ} \mathrm{C}$ (for 30 days and 3 months). Biometric processing of data obtained during the planned study was performed. The research was carried out in the research laboratory of the Federal State Budget Scientific Institution "Federal Scientific Center for Beekeeping". The determination of the activity of the invertase enzyme was performed in accordance with GOST 34232-2017 "Honey. Methods for determining the activity of sucrose (invertase), diastase number, insoluble substance". Experimental samples of natural honey were subjected to negative temperatures in three repetitions, in different time modes; at-5- $8^{\circ} \mathrm{C}$, at $-10^{\circ} \mathrm{C}$, at $-18^{\circ} \mathrm{C}$ (for 30 days and 3 months). The results obtained indicate that the decrease in activity occurred most in samples stored at a temperature of-5-8 ${ }^{\circ} \mathrm{C}$, and averaged $45.9 \pm 2.39 \%$ for the samples. The best retention of activity was observed in honey samples that were stored at a temperature of $-18{ }^{\circ} \mathrm{C}-42.1 \pm 3.06 \%$. The results indicate that the storage of honey under conditions of deeper freezing contributes to a better preservation of the activity of enzymes in its composition.

Key words: honey, invertase activity, negative temperatures, storage conditions.

\section{Literatura}

1.Savina, O.V. Sravnitel'naya ocenka kachestva medovyh kompozicij $s$ ispol'-zovaniem produktov pchelovodstva ryazanskih i kolomenskih proizvoditelej/ O.V. Savina, D.S. Zverev INestnik Ryazanskogo gosudarstvennogo agrotekhnologicheskogo universiteta im. P.A. Kostycheva.- 2017. -№ 4 (36).- S. 69-77.

2. Hel'mut, H. Vse o mede: Obrabotka meda / H. Horn, K. Lyull'man. - M.: Astrel', 2011. - $316 \mathrm{~s}$.

3. Burmistrova, L. A. O bezopasnosti myoda na Rossijskom rynke / L. A. Burmistrova, M. N. Haritonova // Pchelovodstvo. - 2017. - № 6. - S. 50-51.

4. Vatolin, D. O. O mede, i ne tol'ko o nem / D. O. Vatolin // Nauka i zhizn'. - 2008. - № 11. - S. 56-59.

5. GOST 34232 - 2017 «Med. Metody opredeleniya aktivnosti saharazy (invertazy), diastaznogo chisla, nerastvorimogo veshchestva». M.: Standartinform, 2008. 11 s.

6. CHepurnoj, I. P. Ekspertiza kachestva meda/I.P. CHepurnoj. - Stavropol'.. "Kavkazskijkraj», 2000. - 112s.

7. SHkenderov, S. Pchelinye produkty / S. SHkenderov, C. Ivanov. - Sofiya.: ZEMIZDAT, 1985. - 223 s.

8. Bernhard, S. Struktura i funkciya fermentov / C. Bernhard. - M.: «MIR», 1971. - 330 s.

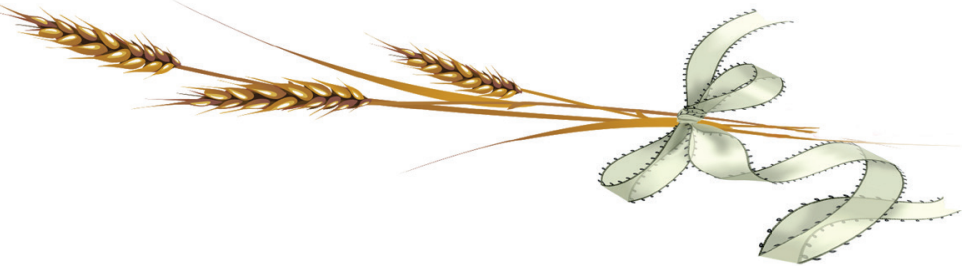


УДК (575.174.015.3+612.664.4):636.2.034

DOI 10.36508/RSATU.2020.45.1.011

\section{АНАЛИЗ ИСПОЛЬЗОВАНИЯ ГЕНОТИПИРОВАНИЯ ПО ПОЛИМОРФНЫМ СИСТЕМАМ ГРУПП КРОВИ И БЕЛКАМ МОЛОКА В ПЛЕМЕННОМ И ПРОМЫШЛЕННОМ СКОТОВОДСТВЕ}

улиВАНОВА Галина Викторовна, канд. биол. наук, доцент кафедры зоотехнии и биологии, darinelle@mail.ru

ГЛОТОВА Галина Николаевна, канд. с.-х. наук, доцент кафедры зоотехнии и биологии, galka270280@yandex.ru

ФЕДОСОВА Ольга Александровна, канд. биол. наук, доцент кафредры зоотехнии и биологии, fedosowa1986@mail.ru

РЫДАНОВА Евгения Андреевна, аспирант кафедры зоотехнии и биологии, rydanova.evgenya@ yandex.ru

Рязанский государственный агротехнологический университет имени П.А. Костычева

Анализ использования генотипирования по полиморфным системам групп крови и белкам молока в племенном и промышленном скотоводстве позволил выявить уменьшение общего количества аллелей полиморфных локусов групп крови крупного рогатого скота. Нашбольшей частотой встречаемости, как и в более ранних исследованиях, отличался аллель G2Y2E'1Q', уровень которого у коров-первотелок исследуемой популяции составил 22,3\%. Полученные результаты в свою очередь свидетельствуют о снижении генетического разнообразия в результате крупномаситабной селекции в племенных хозяйствах Московской и Рязанской областей. Так, снижение генетической изменчивости повлекло за собой увеличение фенотипической однородности стада по основным хозяйственно-полезным признакам. Результаты исследований помогли выявить тенденцию к положительной корреляции между уровнем гомозиготности и величиной удоя за 305 дней первой лактации при начальном уровне гомозиготности в группе более 10\%. Средняя гомозиготность по локусу каппа-казеина (CSN3) у исследуемых групп животных составила примерно 63\%, по локусу бета-лактоглобулина (LGB) - 43\%. Также была отмечена тенденция увеличения частоты встречаемости гетерозиготных генотипов на 6,8\% в группе помесных животных. Было выявлено, что гетерозиготные животные характеризовались стабильностью показателей массовой доли жира в течение трех лактаций от 3,68 до 3,70\%, а с увеличением удоя наблюдалось и незначительное повышение жирномолочности. По итогам третьей лактации у коров-гомозигот массовая доля жира в молоке понизилась на 0,01-0,32\% соответственно. Динамика выхода молочного жира у подопытных животных была аналогична изменению удоев.

Ключевые слова: иммуногенетика, генетический полиморфизм, хозяйственно-полезные признаки, крупный рогатый скот, группы крови, белки молока.

\section{Введение}

В связи с бурным развитием генетических технологий основным методом для совершенствования использования сельскохозяйственных животных в последние годы стал метод ДНК-технологии $[1,7,11]$.

Успехи молекулярной генетики «отодвинули» на задний план такой раздел генетических исследований как иммуногенетика, хотя, по мнению некоторых авторов, весьма незаслуженно. Так Сердюк Г. Н. (2018), ссылаясь на исследования Алтухова Ю. П., в своей статье отмечает, что подобное положение дел ошибочно, так как «...полиморфизм белков, групп крови и ДНК естественным образом дополняют друг друга...» [12]. По словам Ильиной А. В. «...каждая порода (и даже каждое стадо в пределах одной породы) имеет присущую только ему структуру генофонда, которая может отличаться от других популяций» [2].

На основании данных иммуногенетики была обнаружена огромная генетическая изменчивость, позволившая дать объективную оценку основным популяционно-генетическим характеристикам многих видов сельскохозяйственных животных $[4,7,12]$. Поэтому в условиях интенсификации сельскохозяйственной технологии, в частности, широкого внедрения роботизированной техни- ки, необходимо направить усилия на стандартизацию поголовья скота, а этого, в свою очередь, невозможно достичь без понимания тонких генетических механизмов передачи наследственной информации, а также знания уровня генетической изменчивости популяции по комплексу полиморфных локусов [2, 5, 10].

Современные генетические исследования популяций сельскохозяйственных животных, конечно же, не могут обойтись и без изучения генетического полиморфизма белков молока, которые в комплексе с другими методами генетического скрининга позволяют сделать геномную селекцию более эфффективной [1, 3, 6, 8, 9].

В связи с этим целью настоящих исследований явились анализ возможности использования генотипирования по полиморфным системам групп крови и белкам молока крупного рогатого скота в племенном и промышленном скотоводстве, а также оценка влияния уровня изменчивости популяции по полиморфным локусам на степень выраженности основных производственно-технологических признаков.

При выполнении исследований нами были поставлены следующие задачи:

- определить уровень генетической изменчивости в исследуемой популяции по аллелям ЕАВ-

() Уливанова Г. В., Глотова Г. Н., Федосова О.А., Рыданова Е. А., 2020 г. 
локуса, а также частоту встречаемости аллельных вариантов генов полиморфных локусов белков молока (CSN3 и LGB);

- оценить взаимосвязь уровня генетической и фенотипической изменчивости популяции по некоторым хозяйственно-полезным признакам;

- определить силу влияния сменяемости видов подбора на уровень генеалогической однородности популяции;

- изучить взаимосвязь уровня гомозиготности по аллелям EAB-локуса с хозяйственно-полезными признаками и определить оптимальный уровень изменчивости популяции для максимизации положительной взаимосвязи;

- провести анализ в разрезе сочетаний генотипов по полиморфным локусам белков молока с целью оценки их маркерного эффекта по основным хозяйственным и технологическим признакам молочной продуктивности и пригодности к сыроварению.

\section{Материалы и методы исследования}

Экспериментальные исследования проводили на 646 коровах черно-пестрой породы в Рязанской и Московской областях в период с 2006 по 2018 гг. Подбор происходил по принципу аналогов с учетом породности, продуктивности, возраста и живой массы. Кормление животных осуществлялось в соответствии со всеми нормами, корма были сбалансированы по питательным веществам и предназначались конкретно каждой производ- ственно-технологической группе животных.

В исследовании участвовали коровы-первотелки и коровы 3-й лактации, относящиеся к 4 основным линиям и более чем 300 семействам, удой которых был выше средних показателей по стаду.

На первом этапе проводился анализ степени разнообразия аллельных вариантов системы групп крови EAB-локуса в исследуемой популяции крупного рогатого скота черно-пестрой голштинской породы (рис. 1).

На втором этапе был изучен уровень разнообразия данных аллелей и влияние степени генетической изменчивости по группам животных на степень проявления хозяйственно-полезных признаков.

Данные исследования проводили в лаборатории генетики животных Всероссийского государственного НИИ животноводства.

Третий этап включал генотипирование коров по каппа-казеину и бета-лактоглобулину, проводимое в лаборатории ДНК-технологий Всероссийского научно-исследовательского института племенного дела. Ядерная ДНК была выделена из крови крупного рогатого скота фенол-детергентным методом (Blin, N., Stafford, D.W., 1976).

Физико-химические исследования молока проводили общепринятыми методами. Для характеристики технологических качеств молока в лабораторных условиях вырабатывался сыр.

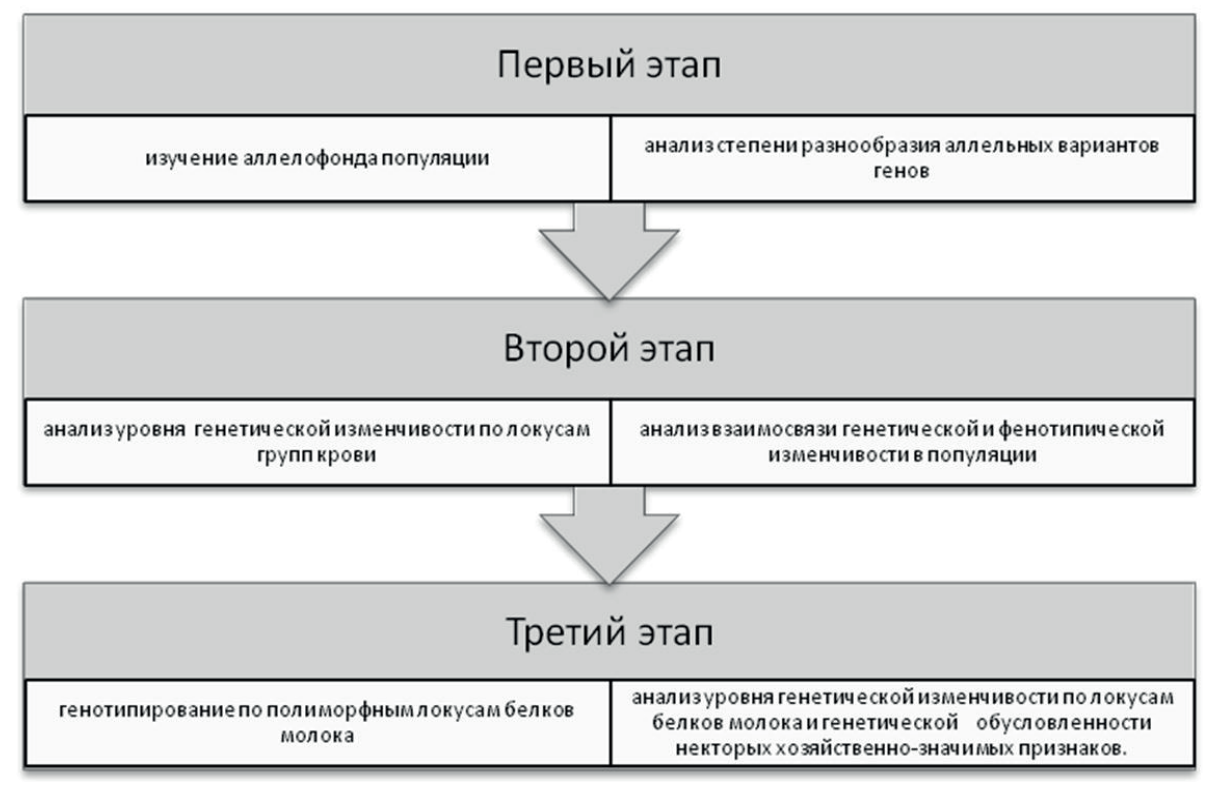

Рис. 1 - Схема исследования

Выделение аллелей производилось по методу Сорокового П. Ф. (1981). Для определения достоверности происхождения животных использовалась методика Матоушека Й. (1964). Уровень генеалогической однородности популяции определялся по формулам Эйснера Ф.Ф. Уровень генетической изменчивости рассчитывался по классической формуле Харди-Вайнберга (1908). Полученные данные подвергались статистической обработке по стандартным методикам (Меркурьева Е. К. (1971).

\section{Результаты исследований и их обсуждение}

В исследованиях ряда ученых отмечалось, что в формировании генотипа исследуемой популяции крупного рогатого скота активное участие принимали несколько родственных европейских пород [10]. Кроме того, в исследованиях этих и других авторов было отмечено, что для популяций крупного рогатого скота Центрального Федерального округа характерно постепенное снижение числа аллеей ЕАВ-локуса.

Для подтверждения этого предположения были 
проведены исследования в нескольких хозяйствах Рязанской и Московской областей.

Изучение динамики аллелофонда стада исследуемых хозяйств показало уменьшение общего количества аллелей, что является косвенным подтверждением предположения о снижении генетического разнообразия.

Так, при оценке аллелофонда коров-первотелок коров ГУП ПНО «Пойма» обнаружен всего 61 аллель ЕАВ-локуса, среди которых встречались аллели, характерные преимущественно для голштинской и голландской черно-пестрой пород крупного рогатого скота. Средняя гомозиготность по группе оказалась в пределах 10\%. Необходимо отметить и высокую частоту встречаемости аллеля G2Y2E'1Q', уровень которого у коров-первотелок составил $22,3 \%$.

Аналогичные исследования, проведенные в СПК им. Ленина, отразили еще более сложную ситуацию. Так, в генотипе коров-первотелок выявлено всего 43 аллеля, что также меньше, чем выявлялось в более ранних исследованиях.
Отцами изучаемой популяции коров-первотелок СПК им. Ленина $(n=109)$ являлись 13 быков-производителей, в то время как отцами их сверстниц из ГУП ПНО «Пойма» $(n=390)$ - всего 7 быков. Такое сравнительно большое количество быков, используемых на сравнительно небольшом поголовье коров СПК им. Ленина послужило основной причиной того, что средний уровень гомозиготности по группе первотелок этого хозяйства оказался ниже - всего около $6,7 \%$, а частота встречаемости самого распространенного аллеля - G2Y2E'1Q' - лишь 18,9 \%, хотя и эти данные говорят о достаточно большой однородности стада.

Для проверки были проведены исследования и в других хозяйствах, ситуация в которых характеризовалась весьма схожей тенденцией.

Снижение генетической изменчивости неизбежно повлекло за собой увеличение фенотипической однородности стада по основным хозяйственно-полезным признакам, таким как удой за 305 дней лактации и массовая доля жира в молоке (рис. 2).

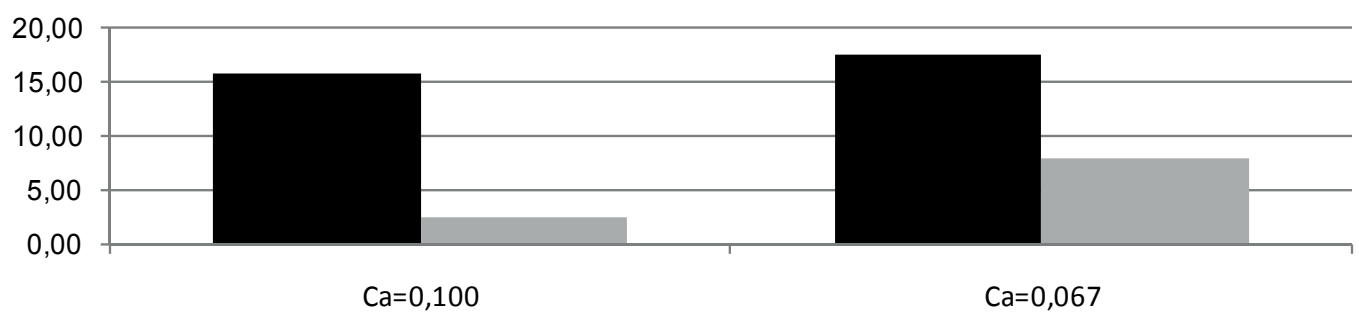

- удой за 305 дней лактации шассовая доля жира

Рис. 2 - Связь уровня гомозиготности популяции $(\mathrm{Ca})$ и фенотипической изменчивости признаков исследуемых групп скота (Cv, \%).

Так, при снижении уровня гомозиготности исследуемой популяции с 0,100 до 0,067 произошло увеличение фенотипической изменчивости по уровню удоя за 305 дней лактации на 1,72\% и по массовой доле жира на 5,38\%. Искусственное же ограничение спектра аллелей в популяции и снижение общей генетической изменчивости стада привело к повышению фенотипической однородности стада.

Для характеристики уровня однородности стада информативным оказывается изучение родословных и определение уровня генеалогической однородности исследуемых популяций. В исследованиях было обнаружено, что уровень генеалогической однородности при двукратном кроссе линий был примерно на 5 \% выше, чем при внутрилинейном подборе. Эта же тенденция выявлена и при расчете относительной однородности группы по доле одного быка, поскольку в группе первотелок, полученных методом двукратного кросса, количество потомков превысило количество кличек быков в трех рядах их родословных. Эти выводы были подтверждены и результатами определения однородности по генетическим маркерам: уровень однородности у первотелок данной группы был выше показателей сверстниц на 11,8\%.

Наивысшей степенью генеалогической однородности отличались группы коров-носительниц аллелей G2Y2E'1Q' (86\%), O4D'E'3F'2G'O' (84\%) и O4E'3G" (81\%), что также подтверждает ранее приведенные выводы о взаимосвязи генетической и генеалогической однородности в группе $(r=0,935)$.

При исследовании взаимосвязи уровня гомозиготности по аллелям ЕАВ-локуса с хозяйственно-полезными признаками обнаружена положительная связь между увеличением уровня гомозиготности и удоев в группе первотелок ГУП ПНО «Пойма» $(r=0,9114)$ при уровне гомозиготности популяции 0,100. В отличие от ГУП ПНО «Пойма» в хозяйствах, характеризующихся более низким уровнем гомозиготности стада, выявлена незначительная отрицательная связь между данными показателями ( $r=-0,221)$.

Таким образом, выявлена тенденция положительной корреляция между уровнем гомозиготности и величиной удоя за 305 дней первой лактации при начальном уровне гомозиготности в группе более 10 \%. При уровне гомозиготности ниже 10\% корреляция между этими показателями 
отрицательная.

Проведенные исследования позволяют говорить о том, что связь уровня генетической и генеалогической изменчивости с хозяйственно-ценными признаками не прямолинейная. Большое влияние на уровень корреляции могут отказывать такие факторы как молочная продуктивность по группам коров, а также характерные особенности рассматриваемых показателей. Таким образом, можно предположить, что в данных условиях и при данном уровне селекции дальнейшее повышение уровня однородности в группе может привести к обособлению ряда признаков и их дальнейшей самостоятельной селекции.

Подтверждением этого предположения служат и рассчитанные коэффрициенты регрессии между уровнем однородности в группе и основными селекционными признаками коров-первотелок.

Расчеты показали, что дальнейшее увеличение уровня генеалогической однородности в группе коров-первотелок, отличающихся сравнительно невысокой продуктивностью, на $1 \%$ может привести к увеличению удоя на 38,2 кг молока за лакта- цию по группе коров, характеризующейся средней продуктивностью на 23,9 кг, а в группе высокопродуктивных коров может снизиться на 78,9 кг. Такая же ситуация отмечена и при изучении показателя «выравненность лактации». Вычисление пределов оптимальности показателей генетической и генеалогической однородности привело к выводу, что уровень однородности в группе, характеризуемый наибольшими положительными эффректами, оказался несколько ниже, чем фрактический показатель этого параметра в исследуемой группе (53,2\% против 78,5\%). Влияние уровня генеалогической однородности на другие хозяйственно-полезные признаки оказалось не таким значительным.

Изучение уровня генетической изменчивости полиморфных белков молока проводилось по локусам каппа-казеина и бета-лактоглобулина (CSN3 и LGB).

Полиморфный локус гена каппа-казеина характеризовался двумя аллелями: А и В с тремя генотипами (AA, AB, BB) (рис. 3).

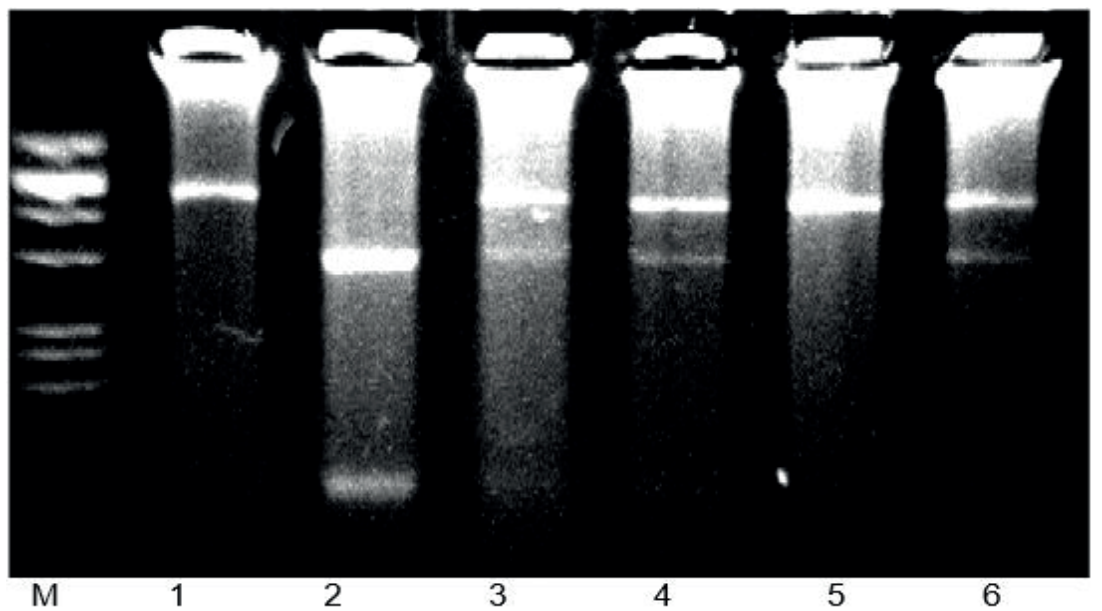

№ 1 - генотип $\mathrm{AA}$, № 2 - генотип $\mathrm{BB}$, № 3, 4 - генотип $\mathrm{AB}$, № 5 - генотип $A$ A, № 6 - генотип $A B$.

Рис. 3 - Рестрикция амплификатов (дорожки № 1, 2, 3, 4, 5, 6)

Оценка уровня изменчивости показала, что средняя гомозиготность по данному локусу у исследуемых групп животных составила примерно $63 \%$, что также характеризует выравненность стада. Уровень гетерозиготных генотипов составил лишь 36-37\%. Наибольшей частотой встречаемости при этом отличался генотип АA - он был отмечен примерно у 58\% обследуемых животных. Наиболее редким генотипом в данном локусе оказался генотип ВВ, частота встречаемости которого составила около 5\% обследуемых животных (рис. 4)

Высокий уровень однородности популяции был отмечен по аллелю А, частота встречаемости которого оказалась в пределах 0,77.

Для более четкого понимания генетической структуры популяции по локусу каппа-казеина было проведено сравнительное исследование частоты встречаемости генотипов данного локуса в зависимости от применяемых методов селекции. Сравнению подлежали чистопородные и помесные животные исследуемых хозяйств. При этом была отмечена тенденция увеличения частоты встречаемости гетерозиготных генотипов на $6,8 \%$ в группе помесных животных.

Кроме того, наметилась определенная тенденция к увеличению частоты гена В, которая колебалась в пределах 0,24, что отражает характерную для данной популяции ситуацию.

Полиморфный локус бета-лактоглобулина (LGB) характеризовался двумя аллельными вариантами гена (A и В). Уровень гетерозиготности данного локуса оказался несколько выше, чем локуса CSN3 - так как частота встречаемости гомозиготных генотипов составила всего около $43 \%$ против $63 \%$ в локусе каппа-казеина. Это свидетельствует о большей степени генетической изменчивости в популяции по данному локусу. Наиболее распространенным аллелем оказался В с частотой встречаемости на уровне 0,68 (рис. 5). 


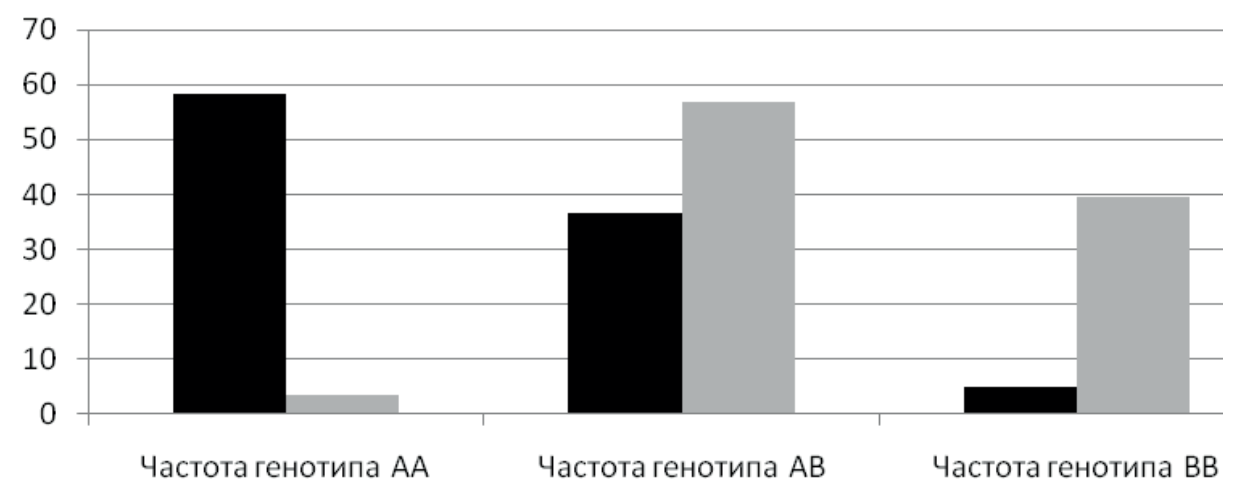

- ожидаемое распределение по локусу CSN3

- ожидаемое распределение по локусу LGB

Рис. 4 - Уровень полиморфизма аллелей локусов CSN3

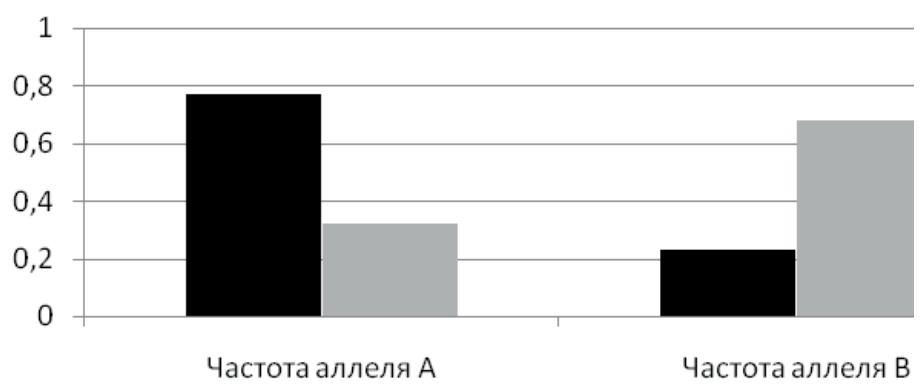

п ожидаемое распределение по локусу CSN3

ожидаемое распределение по локусу LGB

Рис. 5 - Частота встречаемости аллелей полиморфных локусов CSN3 и LGB.

Оценка уровня генетической изменчивости и структуры генотипов по двум полиморфным локусам белков молока позволила установить отсутствие целенаправленных селекционно-генетических мероприятий, направленных на отбор и подбор животных с желательными генотипами по данным полиморфным белкам, поскольку не было установлено статистически достоверного сдвига генетического равновесия ни по одному из изучаемых нами локусов.

Сравнительная оценка степени выраженности хозяйственно-полезных признаков в группах гомозиготных и гетерозиготных животных по исследуемым полиморфным локусам белков молока показала, что гетерозиготные животные характеризовались стабильностью показателей массовой доли жира в течение трех лактаций - от 3,68 до $3,70 \%$, а с увеличением удоя наблюдалось также и незначительное повышение жирномолочности. По итогам третьей лактации у коров-гомозигот массовая доля жира в молоке понизилась на 0,01-0,32\% соответственно. Динамика выхода молочного жира у подопытных животных была аналогична изменению удоев. Тем не менее, анализ молочной продуктивности в разрезе сочетаний генотипов бета-лактоглобулина и каппа-казеина показал, что наиболее интенсивно раздоились животные с сочетанием генотипа каппа-казеина АA, которые превосходили своих сверстниц по удою в течение трех лактаций на 61-444 кг молока соответственно, но уступали им по массовой доле жира в моло- ке на 0,06-0,09\%, в то же время выход молочного жира был также выше у них. У коров, сочетавших генотип бета-лактоглобулина $A B$ и каппа-казеина AA, с повышением удоя увеличивалась и массовая доля жира в молоке.

Таким образом, для получения цельномолочной продукции следует отдавать предпочтение животным, сочетающим генотип бета-лактоглобулина ВВ и каппа-казеина АВ. Молоко коров с генотипами $A B$ по бета-лактоглобулину и каппа-казеину целесообразнее использовать для выработки жирномолочных продуктов.

При исследовании технологической пригодности молока для производства сыров было выявлено сокращение времени коагуляции казеина у животных с генотипом ВВ по данному локусу, а в фразе гелеобразования генетическая обусловленность данного технологического признака проявилась наиболее ярко: данная фраза у коров с генотипом ВВ была на 6,7 мин короче $(P<0,05)$, чем у животных с генотипом АА. Уровень свертываемости молока гетерозиготных по локусу каппаказеина коров занимал промежуточное положение (27,3 мин), что наводит на мысль о наследовании данного признака по принципу неполного доминирования.

\section{Выводы}

1. Уровень гомозиготности популяции (Ca), рассчитанный по аллелям ЕАВ-локуса, колебался в пределах 7,6-9,1\%. Проведенный анализ аллелофонда популяции черно-пестрой породы крупного 
рогатого скота показал высокий уровень встречаемости таких аллеей EAB-локуса, как G2Y2E'1Q' O4E'3G", O2A'2J'1K'O', I2 с частотой встречаемости более 5\%. Наибольшей частотой встречаемости характеризовался аллель G2Y2E'1Q' - 20-24\% всего аллелофонда популяции.

2. Показатели генетической и фенотипической изменчивости характеризуются одной тенденцией. Искусственное ограничение спектра аллелей и снижение общей генетической изменчивости стада привело к повышению фенотипической однородности стада, в то время как при продолжительном линейном разведении без учета генетической изменчивости по аллелям групп крови развивается тенденция к снижению уровня однородности стада.

3. Уровень генеалогической однородности при двукратном кроссе линий примерно на 5\% выше, чем при внутрилинейном подборе. Эта же тенденция обнаружена и при расчете относительной однородности группы по доле одного быка, поскольку в группе первотелок, полученных методом двукратного кросса, количество потомков превысило количество кличек быков в трех рядах их родословных. Эти выводы были подтверждены и результатами определения однородности по генетическим маркерам: уровень однородности у первотелок данной группы был выше показателей сверстниц на $11,8 \%$.

4. Выявлена тенденция положительной корреляция между уровнем гомозиготности и величиной удоя за 305 дней первой лактации при начальном уровне гомозиготности в группе более 10\%. При уровне гомозиготности ниже $10 \%$, корреляция между этими показателями отрицательная.

5. Выявлено три генотипа по локусу гена каппа-казеина - $\mathrm{AA}, \mathrm{AB}$ и $\mathrm{BB}$, из которых наибольшей частотой встречаемости отличался генотип AA (58\%) Наиболее редким генотипом в данном локусе оказался генотип ВВ (5\%). Уровень гетерозиготных генотипов составил лишь 36-37\%, что говорит о высоком уровне однородности поголовья по данному полиморфному локусу. Отмечена высокая однородность популяции по аллелю $\mathrm{A}$, частота встречаемости которого оказалась в пределах 0,77. При этом была отмечена тенденция увеличения частоты встречаемости гетерозиготных генотипов на $6,8 \%$ в группе помесных животных. По локусу бета-лактоглобулина так же было выявлено два аллельных гена A и В и 3 генотипа. Частота встречаемости гомозиготных генотипов в данном полиморфном локусе белков молока была гораздо ниже, чем в локусе каппа-казенина - всего около $43 \%$ против $63 \%$ в локусе каппа-казеина. Это свидетельствует о большей степени генетической изменчивости в популяции по данному локусу. Наиболее распространенным оказался аллель В с частотой встречаемости на уровне 0,68.

6. Сравнительная оценка степени выраженности хозяйственно-полезных признаков в группах гомозиготных и гетерозиготных животных по исследуемым полиморфным локусам белков молока показала, что гетерозиготные животные характеризовались стабильностью показателей массовой доли жира в течение трех лактаций - от 3,68 до $3,70 \%$, а с увеличением удоя наблюдалось и незначительное повышение жирномолочности. По итогам третьей лактации у коров-гомозигот массовая доля жира в молоке понизилась на 0,01-0,32\% соответственно. Динамика выхода молочного жира у подопытных животных была аналогична изменению удоев.

7. При исследовании технологической пригодности молока для производства сыров было выявлено сокращение времени коагуляции казеина у животных с генотипом ВВ по данному локусу, а в фазе гелеобразования генетическая обусловленность технологического признака проявилась наиболее ярко: данная фаза у коров с генотипом ВB была на 6,7 мин короче $(\mathrm{P}<0,05)$, чем у животных с генотипом АА. Уровень свертываемости молока гетерозиготных по локусу каппа-казеина коров занимал промежуточное положение (27,3 мин).

\section{Список литературы}

1. Глазко, В.И. Доменная организация мобильных генетических элементов в 1-й хромосоме крупного рогатого скота [Текст] / В.И. Глазко, О.И. Скобель, Г.Ю. Косовский // Сельскохозяйственная биология. - 2017. - Том 52. - № 4. - С. 658-668.

2. Ильина, А.В. Генетическая оценка состояния популяционного генофонда крупного рогатого скота Ярославской породы в ОАО «Михайловское» Ярославского района [Текст] / А.В. Ильина, Ю.В. Муштукова, О.А. Хуртина // Вестник АПК Верхневолжья. - 2014. - № 4(28). - С. 39-43.

3. Калашникова, Л.А. Полиморфизм генов CSN3, LGB, PRL, GH у голштинских коров [Текст] / Л.А. Калашникова, Я.А. Хабибрахманова, Г.М. Джапаридзе, В.Г. Труфанов // Зоотехния. - 2018. - № 2. - C. 8-9.

4. Мысик, А.Т. Новый метод определения генетической корреляции [Текст] / А.Т. Мысик, И.Ш. Тамаев, М.Б. Улимбашев, М.Г. Чабаев, Т.В. Лепехина // Зоотехния. - 2017. - № 11. - С. 8-11.

5. Племенная ценность холмогорского скота с учетом полиморфизма генов молочных белков [Текст] / Р.В. Некрасов, А.С. Аникин, В.М. Дуборезов и др. // Зоотехния. - 2018. - № 9.- С. 7-10.

6. Позовникова, М.В. Оценка генетического потенциала отечественного скота по признакам высокого качества мяса на основе ДНК-маркерных систем [Текст] / М.В. Позовникова, О.В. Сердюк, В.П. Тулинова и др. // Проблемы биологии продуктивных животных. - 2011. - № 1. - С. 62-64.

7. Попов, Н.А. Аллелофонд голштинской породы и его использование для совершенствования молочности крупного рогатого скота Российской Федерации [Текст] / Н.А. Попов, Л.К. Марзанова, А.А. Некрасов, Е.Г. Федотова // Молочное и мясное скотоводство. - 2018. - № 4. - С. 14-19.

8. Попов, Н.А. Аллелофонд пород крупного рогатого скота по ЕАВ-локусу [Текст] / Н.А. Попов, Г.В. Ескин // Справочный каталог. - М., 2000. - 300 с.

9. Проблемы реализации потенциала продуктивности молочного скота [Текст] / А.А. Сермягин, А.В. Ермилов, И.Н. Янчуков и др. // Зоотехния. 2017. - № 3. - С. 7-12.

10. Сердюк, Г.Н. Группы крови и их значение в организме млекопитающих [Текст] / Г.Н. Сердюк // Генетика и разведение животных. - 2018. - № 2. C. $94-100$.

11. Kgwatalala, P.M. Single nucleotide polymorphisms in the open reading frame of the 
stearoyl-CoA desaturase gene and resulting genetic variants in Canadian Holstein and Jersey cows. [Текст] / P.M. Kgwatalala, E.M. Ibeagha Awemu, J.F. Hayes, X. Zhao // DNA Sequence. - 2007. - 18(5). P. 357-362.
12. Legarova, V. The effect of k-casein genotype on the quaiity of milk and fresh cheese [Текст] / V. Legarova, L. Kourimska // Scientia Agriculturae Bohemica. - 2010. - 41 (4). - P. 213-217

\section{ANALYSIS OF THE USE OF GENOTYPING BY POLYMORPHIC SYSTEMS OF BLOOD GROUPS AND MILK PROTEINS IN BREEDING AND INDUSTRIAL CATTLE BREEDING}

Ulivanova Galina V., cand. biol. associate Professor of the Department of animal science and biology, darinelle@mail.ru

Glotova Galina N., cand. of agricultural sciences, associate Professor of the Department of animal science and biology, galka270280@yandex.ru

Fedosova Olga A., cand. biol. associate Professor of the Department of animal science and biology, fedosowa1986@mail.ru

Rydanova Evgenia A., post-graduate student of the Department of animal science and biology, rydanova. evgenya@yandex.ru

Ryazan state agrotechnological University named after P. A. Kostychev

Analysis of the use of genotyping for polymorphic systems of blood groups and milk proteins in breeding and industrial cattle breeding revealed a decrease in the total number of alleles of polymorphic loci of bovine blood groups. The highest frequency of occurrence, as in earlier studies, differed allele G2Y2 '1Q', the level of which in the first-calf cows of the study population was 22,3\%. The results obtained, in turn, indicate a decrease in genetic diversity as a result of large-scale selection in breeding farms in the Moscow and Ryazan regions. Thus, the decrease in genetic variability resulted in an increase in the phenotypic homogeneity of the herd on the main economic and useful features. The results of the research helped to identify a tendency to a positive correlation between the level of homozygosity and the value of milk yield for 305 days of the first lactation with an initial level of homozygosity in the group of more than $10 \%$. The average homozygosity for the Kappacasein locus (CSN3) in the studied groups of animals was approximately $63 \%$, for the beta-lactoglobulin locus (LGB) - $43 \%$. There was also a tendency to increase the frequency of heterozygous genotypes by 6,8 \% in the group of crossbred animals. It was found that heterozygous animals were characterized by a stable mass fraction of fat during three lactation from 3,68 to 3,70 \%, and with an increase in milk yield, there was also a slight increase in fat content. According to the results of the third lactation in homozygous cows, the mass fraction of fat in milk decreased by 0,01-0,32 \%, respectively. The dynamics of milk fat yield in experimental animals was similar to the change in milk yields.

Key words: immunogenetics, genetic polymorphism, economically useful traits, cattle, blood groups, milk proteins.

\section{Literatura}

1. Glazko, V.I. Domennaya organizaciya mobil'nyh geneticheskih elementov v 1-j hromosome krupnogo rogatogo skota [Tekst] / V.I. Glazko, O.I. Skobel', G.YU. Kosovskij // Sel'skohozyajstvennaya biologiya. - 2017. - Tom 52. - № 4. - S. 658-668.

2. Il'ina, A.V. Geneticheskaya ocenka sostoyaniya populyacionnogo genofonda krupnogo rogatogo skota YAroslavskoj porody v OAO «Mihajlovskoe» YAroslavskogo rajona [Tekst] /A.V. II'ina, YU.V. Mushtukova, O.A. Hurtina // Vestnik APK Verhnevolzh'ya. - 2014. - № 4(28). - S. 39-43.

3. Kalashnikova, L.A. Polimorfizm genov CSN3, LGB, PRL, GH u golshtinskih korov [Tekst] / L.A. Kalashnikova, YA.A. Habibrahmanova, G.M. Dzhaparidze, V.G. Trufanov //Zootekhniya. - 2018. - № 2. - S. 8-9.

4. Mysik, A.T. Novyj metod opredeleniya geneticheskoj korrelyacii [Tekst] / A.T. Mysik, I.SH. Tamaev, M.B. Ulimbashev, M.G. CHabaev, T.V. Lepekhina // Zootekhniya. - 2017. - № 11. - S. 8-11.

5. Plemennaya cennost' holmogorskogo skota s uchetom polimorfizma genov molochnyh belkov [Tekst] / R. V. Nekrasov, A.S. Anikin, V.M. Duborezov i dr. // Zootekhniya. - 2018. - № 9.- S. 7-10.

6. Pozovnikova, M.V. Ocenka geneticheskogo potenciala otechestvennogo skota po priznakam vysokogo kachestva myasa na osnove DNK-markernyh sistem [Tekst] / M.V. Pozovnikova, O.V. Serdyuk, V.P. Tulinova i dr. // Problemy biologii produktivnyh zhivotnyh. - 2011. - № 1. - S. 62-64.

7. Popov, N.A. Allelofond golshtinskoj porody i ego ispol'zovanie dlya sovershenstvovaniya molochnosti krupnogo rogatogo skota Rossijskoj Federacii [Tekst] / N.A. Popov, L.K. Marzanova, A.A. Nekrasov, E.G. Fedotova // Molochnoe i myasnoe skotovodstvo. - 2018. - № 4. - S. 14-19.

8. Popov, N.A. Allelofond porod krupnogo rogatogo skota po EAB-lokusu [Tekst] / N.A. Popov, G. V. Eskin // Spravochnyj katalog. - M., 2000. - 300 s.

9. Problemy realizacii potenciala produktivnosti molochnogo skota [Tekst] / A.A. Sermyagin, A.V. Ermilov, I.N. YAnchukov i dr. // Zootekhniya. - 2017. - № 3. - S. 7-12.

10. Serdyuk, G.N. Gruppy krovi $i$ ih znachenie v organizme mlekopitayushchih [Tekst] / G.N. Serdyuk // Genetika i razvedenie zhivotnyh. - 2018. - № 2. - S. 94-100.

11. Kgwatalala, P.M. Single nucleotide polymorphisms in the open reading frame of the stearoyl-CoA desaturase gene and resulting genetic variants in Canadian Holstein and Jersey cows. [Tekst]/P.M. Kgwatalala, E.M. Ibeagha Awemu, J.F. Hayes, X. Zhao // DNA Sequence. - 2007. - 18(5). - R. 357-362.

12. Legarova, $V$. The effect of $k$-casein genotype on the quaiity of milk and fresh cheese [Tekst]/V. Legarova, L. Kourimska // Scientia Agriculturae Bohemica. - 2010. - 41 (4). - R. 213-217. 


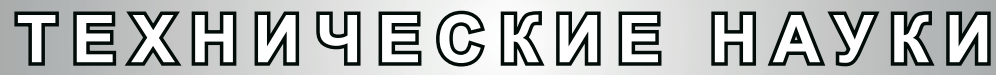

УДК 638.163.4/638.178

\section{ИССЛЕДОВАНИЕ ПРОЧНОСТИ ЯЧЕЕК ПРИ ИЗГИБЕ ПЧЕЛИНОГО СОТА}

АФАНАСЬЕВ Александр Михайлович, соискатель кафредры технологии металлов и ремонта машин, Km340010@rambler.ru

КОСТЕНКО Михаил Юрьевич, д-р техн. наук, доцент, профрессор кафедры технологии металлов и ремонта машин, Km340010@rambler.ru

АФАНАСЬЕВ Михаил Юрьевич, канд. с.-х. наук, доцент, доцент кафедры электротехники и фризики, Km340010@rambler.ru

Рязанский государственный агротехнологический университет имени П.А. Костычева

МАМОНОВ Роман Александрович, д-р техн. наук, дочент, профрессор кафредры тылового обеспечения уголовно-исполнительной системы, ФКОУ ВО «Академия права и управления Федеральной службы исполнения назначения», mamonov.agrotexnol@yandex.ru

Высокая рентабельность получения продуктов пчеловодства зависит от эфрфективного использования пчелиных сотов в технологии содержания пчел, а также получения продуктов пчеловодства. При откачке меда часть сотовых рамок выбраковывается из-за деформации сотовой структуры, образования трещин и разрывов в ней. Для восполнения выбракованных сотов приходится дополнительно закупать листы вощины, терять время и расходовать потенциал пчелиной семьи на отстройку структуры сотовых рамок. Нами проведены исследования действия центробежных сил на сотовую структуру при различных способах размещении сотовой рамки в роторе иентрифуги. С помощью метода вырезания узлов были найдены усилия, возникающие в узлах шестигранной ячейки сота. При увеличении угловой скорости вращения ротора растягивающая нагрузка на ячейки сота возрастает интенсивно. При угловой скорости 26 рад/с растягивающие напряжения при вертикальном расположении сота составляют $3,479 * 10^{5}$ Па - почти в 1,73 раза выше, чем при горизонтальном положении - 2,009*105 Па, и могут привести к разрыву восковых пластинок ячеек. Предельные растягивающие напряжения 200 кПа достигаются при угловой скорости выше 26 рад/с. Поэтому при откачке меда следует ограничивать скорость вращения вертикально расположенных рамок для снижения нагрузки и исключения повреждения ячеек пчелиных сотов, особенно в начале процесса откачки меда. Анализ полученных уравнений установил, что увеличение угловой скорости выше 26 рад/с приводит к прогрессивному росту нормальных напряжений в ячейках сота. При вертикальном расположении сота в роторе центрифуги предельные разрушающие нагрузки ячеек сота возникают при меньщей частоте вращения. Выявлено, что образование трещин зависит от радиуса кривизны сотовой структуры и для проведения скарифрикации перговых сотов он должен составлять около 0,55 м.

Ключевые слова: медогонки, сотовые рамки, продукты пчеловодства, откачка меда, перга, скарифрикация перговых сотов, ячеки сотов.

\section{Введение}

Высокая рентабельность получения продуктов пчеловодства зависит от эфрфективного использования пчелиных сотов в технологии содержания пчел, а также получения продуктов пчеловодства. Мед и перга являются основными продуктами, для приготовления и хранения которых пчелы используют восковые соты [1, 2]. В технологиях извлечения продуктов пчеловодства из сотов используют центробежные силы [3-6]. При откачке меда часть сотовых рамок выбраковывается из-за десрормации сотовой структуры, образования трещин и разрывов в ней. Для восполнения выбракованных сотов приходится дополнительно закупать листы вощины, терять время и расходовать потенциал пчелиной семьи на отстройку структуры сотовых рамок. Воздействие центробежных сил на восковую структуру пчелиных сотов мало изучено.

\section{Объекты и методы исследований}

Нами разработан комплексный агрегат для откачки меда и скарификации перговых сотов

$[1,4,7]$. Определим реакции, возникающие в узлах восковых ячеек сота при воздействии на сот центробежных сил. Воспользуемся методом вырезания узлов и, применив принцип независимости действия сил, определим усилия, возникающие в

() Афанасьев А. М., Костенко М. Ю., Афанасьев М. Ю., Мамонов Р. А., 2020 г. 
узлах ячейки сота (рис. 1) [8].

Введем следующие допущения:

1) растягивающие силы в одном из узлов будут соответственно параллельны друг другу в различных узлах;

2) все ячейки сота деформируются одинаково в пределах цилиндрической поверхности деформированного сота;

3) толщина всех восковых стенок ячейки сота одинакова;

4) толщина крышек на каждом соте однородна и одинакова.

Так как величина центробежной силы зависит от радиуса вращения ячейки сота, то максимальные значения сил растяжения будут достигаться на краю сота, в месте крепления вощины к деревянной рамке $[9,10]$. Исследуем реакции в ячейках сота при наибольших значениях центробежных сил.

\section{Результаты исследований}

Рассмотрим действие сил в узле 1 (рис. 1) при вертикальном расположении сота в кассете ротора центрифуги (верхний брус рамки расположен вертикально). Уравнения равновесия выглядят следующим образом

$\left\{\begin{array}{cl}\Sigma \mathrm{x}=0 & \mathrm{R}_{61} \cos 60^{\circ}+\mathrm{R}_{1}^{\prime} \cos 60^{\circ}-\mathrm{R}_{21}=0 \\ \Sigma \mathrm{y}=0 & \mathrm{R}_{61} \sin 60^{\circ}-\mathrm{R}_{1}^{\prime} \sin 60^{\circ}=0\end{array}\right.$

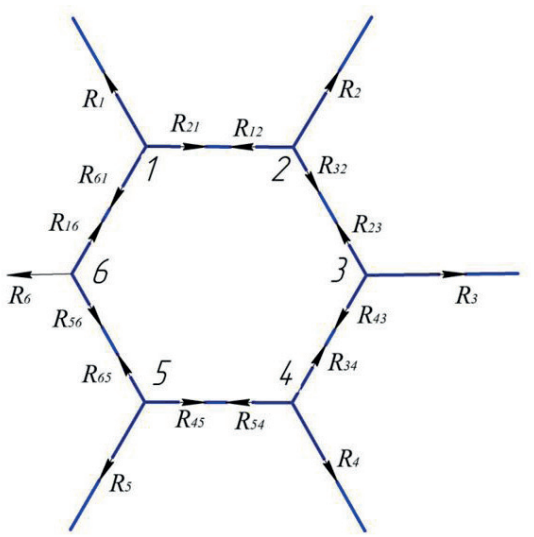

Рис. 1 - Расчетная схема к определению усилий в узлах 1-6 ячейки сота

Аналогичные уравнения можем записать для остальных узлов.

Для узла 2: $\left\{\begin{array}{cc}\Sigma \mathrm{x}=0 & \mathrm{R}_{32} \cos 60^{\circ}+\mathrm{R}_{2}^{\prime} \cos 60^{\circ}-\mathrm{R}_{12}=0 \\ \Sigma \mathrm{y}=0 & \mathrm{R}_{32} \sin 60^{\circ}-\mathrm{R}_{2}^{\prime} \sin 60^{\circ}=0\end{array}\right.$

Для узла 3: $\begin{cases}\Sigma \mathrm{x}=0 & \mathrm{R}_{23} \cos 60^{\circ}+\mathrm{R}_{43} \cos 60^{\circ}-\mathrm{R}_{3}^{\prime}=0 \\ \Sigma \mathrm{y}=0 & 0\end{cases}$

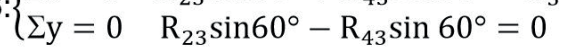

Для узла $4:\left\{\begin{array}{cc}\Sigma \mathrm{x}=0 & \mathrm{R}_{34} \cos 60^{\circ}+\mathrm{R}_{4}^{\prime} \cos 60^{\circ}-\mathrm{R}_{12}=0 \\ \Sigma \mathrm{y}=0 & \mathrm{R}_{34} \sin 60^{\circ}-\mathrm{R}_{4}^{\prime} \sin 60^{\circ}=0\end{array}\right.$

Для узла 5: $\left\{\begin{array}{cc}\Sigma \mathrm{x}=0 & \mathrm{R}_{65} \cos 60^{\circ}+\mathrm{R}_{5}^{\prime} \cos 60^{\circ}-\mathrm{R}_{45}=0 \\ \Sigma \mathrm{y}=0 & \mathrm{R}_{65} \sin 60^{\circ}-\mathrm{R}_{5}^{\prime} \sin 60^{\circ}=0\end{array}\right.$

Для узла 6: $\left\{\begin{array}{cc}\Sigma \mathrm{x}=0 & \mathrm{~F}_{ц 6}^{\tau}-\mathrm{R}_{16} \cos 60^{\circ}-\mathrm{R}_{56} \cos 60^{\circ}=0 \\ \Sigma \mathrm{y}=0 & \mathrm{R}_{16} \sin 60^{\circ}-\mathrm{R}_{56} \sin 60^{\circ}=0\end{array}\right.$
В результате решения системы уравнений получены значения неизвестных реакций:

$\mathrm{R}_{21}=\mathrm{R}_{23}=\mathrm{R}_{43}=\mathrm{R}_{54}=\mathrm{R}_{56}=\mathrm{R}_{16}=\mathrm{F}_{\mathrm{L \sigma}}^{\tau}$

Рассчитаем растягивающее напряжение, действующее на боковую стенку (восковую пластинку) ячейки сота (рис.2). Так как при изгибе напряжение и продольные силы равномерно возрастают от нейтрального слоя (вощины), логично предположить, что распределенная нагрузка также равномерно убывает от усилия на внешней стороне сотов и убывает до нуля на нейтральном слое, расположенном на вощине. Определим значение продольной силы и нормального напряжения восковой пластинки.

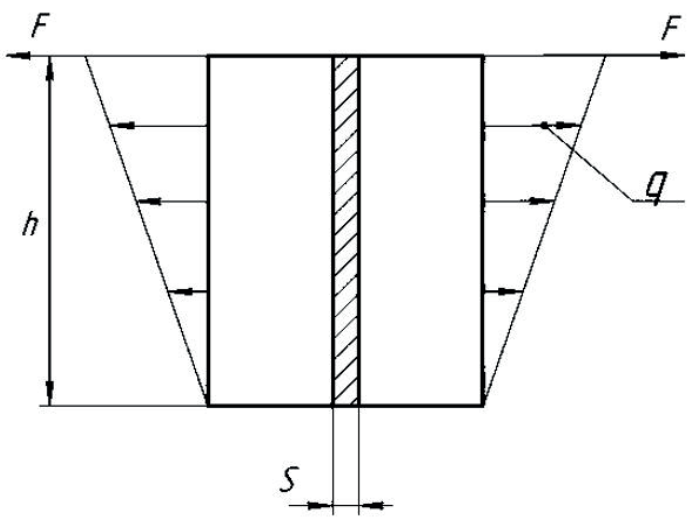

Рис. 2 - Расчетная схема для определения прочности восковой стенки ячейки сота при вертикальном расположении

Максимальное значение распределенной нагрузки определяется по фрормуле:

$q_{\max }=\frac{2 F_{ц б}^{\tau}}{h}$

где $F=F_{ц б}^{\tau}$ растягивающее усилие (касательная составляющая центробежной силы, действующая на ячейкусота), $\mathrm{H}$;

$$
\mathrm{h} \text { - высота ячейки сота, м. }
$$

Так как распределенная нагрузка на ячейку зависит от высоты ячейки сота, то уравнение (8) можно записать

$$
q\left(z_{1}\right)=\frac{2 F_{\text {цб }}^{\tau}}{z_{1}}
$$

Рассмотрим сечение стенки (пластины) ячейки сота $0<\mathrm{z} 1<\mathrm{h}$

$\Sigma \mathrm{z}_{1}=0 \quad N=q\left(z_{1}\right) z_{1}$

Нормальное напряжение при растяжении стенки восковой ячейки определим по формуле:

$\sigma_{1}=\frac{N_{1}}{\mathrm{~A}}$

где N1 - продольная сила, $\mathrm{H}$;

А - площадь поперечного сечения восковой стенки (пластины) ячейки сота, м². 
При $\mathrm{z}_{1}=0 ; \mathrm{N}_{1}=0 ; \sigma_{1}=0$

При $\mathrm{z}_{1}=h ; \mathrm{N}_{1}=q(h) h=2 F_{ц б}^{\tau}$

$\sigma_{1}=\frac{N_{1}}{\mathrm{~A}}=\frac{2 F_{ц 5}^{\tau}}{h \cdot S}$

Построим в программе Mathcad 15 зависимость напряжений, возникающих в ячейках при вертикальном расположении сота, от угловой скорости ротора на основании уравнения 11 (рис. 3).

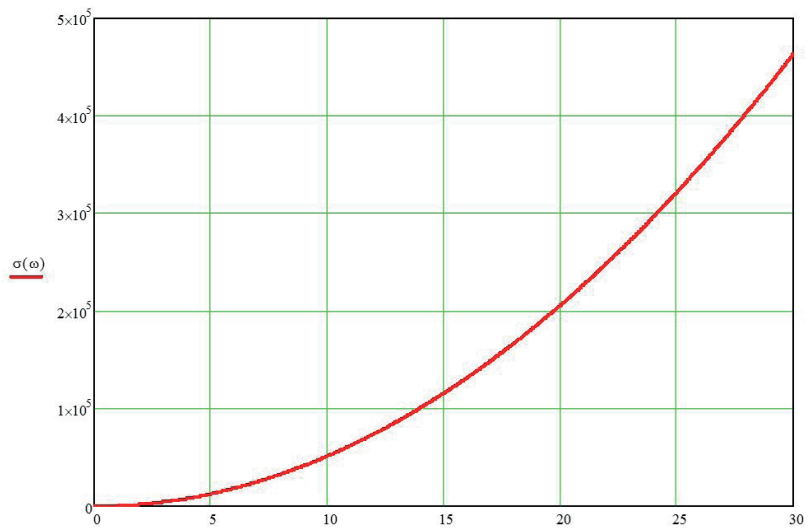

Рис. 3 - Зависимость напряжений б1 (Па), возникающих в ячейках при вертикальном расположении сота, от угловой скорости ротора $\omega$ (рад/с) комплексного агрегата

Анализ рисунка 3 показывает, что при увеличении угловой скорости вращения ротора растягивающая нагрузка на ячейки сота возрастает, и при увеличении угловой скорости свыше 20 рад/с растягивающие усилия резко возрастают. Допускаемые напряжения для воска при температуре $25{ }^{\circ} \mathrm{C}$ составляют около 200 кПа, поэтому увеличение угловой скорости свыше 20 рад/с может привести к разрыву восковых пластинок ячеек [7].

Исследуем силы, возникающие при горизонтальном расположение сота в роторе центрифруги (верхний брус рамки расположен горизонтально). Под воздействием центробежных сил в узловых точках соединения стенок ячеек возникают усилия (рис. 4).

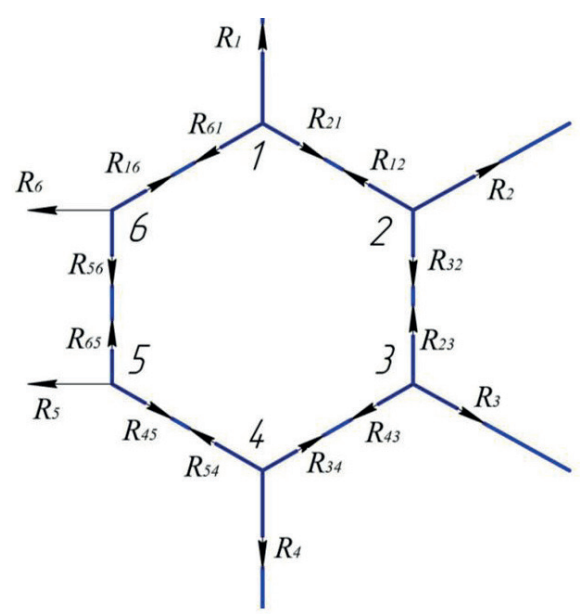

Рис. 4 - Расчетная схема для определения реакций в узле 1 при горизонтальном расположении сота нии

Рассмотрим узел 1 при поперечном расположе-

$$
\begin{cases}\Sigma \mathrm{x}=0 & \mathrm{R}_{61} \sin 60^{\circ}-\mathrm{R}_{12} \sin 60^{\circ}=0 \\ \Sigma \mathrm{y}=0 & \mathrm{R}_{16} \cos 60^{\circ}+\mathrm{R}_{12} \cos 60^{\circ}-\mathrm{R}_{1}=0\end{cases}
$$

Для узла 2: $\begin{cases}\Sigma \mathrm{x}=0 & \mathrm{R}_{12} \sin 60^{\circ}+\mathrm{R}_{2} \sin 60^{\circ}=0 \\ \Sigma \mathrm{y}=0 & \mathrm{R}_{12} \cos 60^{\circ}+\mathrm{R}_{2} \cos 60^{\circ}-\mathrm{R}_{23}=0\end{cases}$

Для узла 3: $\left\{\begin{array}{ccc}\Sigma \mathrm{x}=0 & \mathrm{R}_{34} \sin 60^{\circ}+\mathrm{R}_{3} \sin 60^{\circ}=0 \quad(14) \\ \Sigma \mathrm{y}=0 & \mathrm{R}_{34} \cos 60^{\circ}+\mathrm{R}_{3} \cos 60^{\circ}-\mathrm{R}_{23}=0\end{array}\right.$

Для узла $4:\left\{\begin{array}{cc}\Sigma \mathrm{x}=0 \\ \Sigma \mathrm{y}=0\end{array} \mathrm{R}_{43} \sin 60^{\circ}-\mathrm{R}_{45} \sin 60^{\circ}=0\right.$

Для узла $5:\left\{\begin{array}{cc}\Sigma \mathrm{x}=0 & \mathrm{~F}_{\text {цб }}^{\tau}-\mathrm{R}_{54} \sin 60^{\circ}=0 \\ \Sigma \mathrm{y}=0 & \mathrm{R}_{54} \cos 60^{\circ}-\mathrm{R}_{56}=0\end{array}\right.$

Для узла $6: \begin{cases}\Sigma \mathrm{x}=0 & \mathrm{~F}-\mathrm{R}_{61} \sin 60^{\circ}=0 \\ \Sigma \mathrm{y}=0 & \mathrm{R}_{61} \cos 60^{\circ}-\mathrm{R}_{56}=0\end{cases}$

В результате решения системы уравнений нами получены значения неизвестных реакций:

$\mathrm{R}_{21}=\mathrm{R}_{23}=\mathrm{R}_{43}=\mathrm{R}_{54}=\mathrm{R}_{56}=\mathrm{R}_{16}=\frac{\mathrm{F}_{46}^{\tau}}{\sin 60^{\circ}}=$ $=\frac{2 \sqrt{3}}{3} \mathrm{~F}_{\text {цб }}^{\tau}$

Рассмотрим прочность ячейки сота при горизонтальном расположении сота. Распределенная нагрузка зависит от высоты ячейки сота и ее можно записать в виде

$q\left(z_{2}\right)=\frac{\frac{2 \sqrt{3}}{3} F_{\text {цб }}^{\tau}}{z_{2}}$

Рассмотрим сечение пластины сота $0<\mathrm{z} 2<\mathrm{h}$

$\Sigma z_{2}=0 \quad N_{2}=q\left(z_{2}\right) z_{2}$

Нормальное напряжение при растяжении определим по формуле:

$$
\sigma_{2}=\frac{N_{2}}{\mathrm{~A}}
$$

где N2- продольная сила, $\mathrm{H}$;

A - площадь поперечного сечения восковой

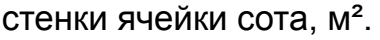

При $\mathrm{z}_{2}=0 ; \quad \mathrm{N}_{2}=0 ; \sigma_{2}=0$

При $\mathrm{z}_{2}=h ; \quad \mathrm{N}_{2}=q(h) h$;

$N_{2}=\frac{2 \sqrt{3}}{3} F_{ц б}^{\tau} h ; \sigma_{2}=\frac{N_{2}}{\mathrm{~A}}=\frac{2 \sqrt{3} F_{ц б}^{\tau}}{3 h \cdot S}$

Построим в программе Mathcad 15 зависимость напряжений, возникающих в ячейках при горизонтальном расположении сота, от угловой скорости ротора на основании уравнения 21 (рис. 5).

Анализ рисунка 5 показывает, что при увеличении угловой скорости вращения ротора растягивающая нагрузка на ячейки при горизонтальном расположении сота возрастает менее интенсивно, чем при вертикальном. Предельные растягивающие напряжения 200 кПа достигаются при угловой скорости выше 26 рад/с. При угловой скорости 26 рад/с растягивающие напряжения при вертикальном расположении сота составляют $3,479 * 10^{5}$ Па - почти в 1,73 раза выше, чем при горизонтальном положении - 2,009*105 Па, и 
может привести к разрыву восковых пластинок ячеек. Поэтому при откачке меда следует ограничивать скорость вращения вертикально расположенных рамок для снижения нагрузки и исключения повреждения ячеек пчелиных сотов, особенно в начале процесса откачки меда.

При скарификации перговых сотов возникает необходимость частичного деформирования и разрушения стенок и крышек ячеек для интенсификации вывода влаги при сушке перги. Рассчитаем растягивающие усилия и напряжения, возникающие в крышках ячеек сотов. Учитывая, что ячейки сотов представляют собой правильные шестиугольники, реакции восковых стенок ячейки будут равны друг другу, а усилия, действующие на крышки ячеек сотов, будут параллельны. Соответственно, крышка ячейки сота будет находиться под действием параллельных сил, а нагрузка равномерно распределена по всей её ширине (рис. 6).

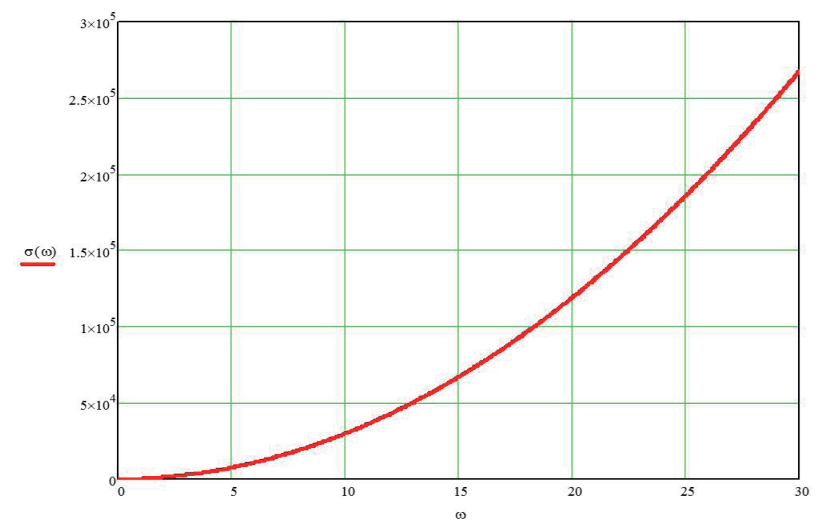

Рис. 5 - Зависимость напряжений б2 (Па), возникающих в ячейках при горизонтальном расположении сота, от угловой скорости $\omega$ (рад/с) ротора комплексного агрегата

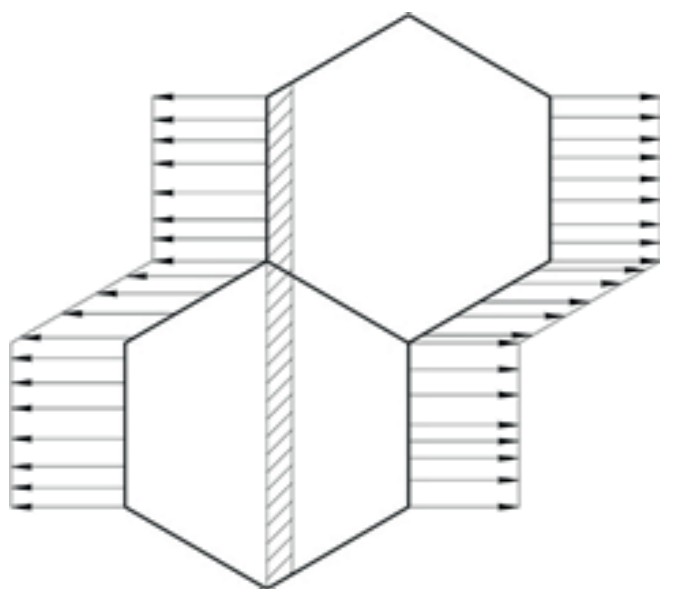

Рис. 6 - Расчетная схема для определения прочности ячейки сота

Равномерно распределенная нагрузка, действующая на крышку ячейки сота, определяется по фрормуле:

$q_{\text {кр }}=3 \frac{F_{\text {цб }}^{\tau}}{3 \cdot l}$ где $F_{ц б}^{\tau}-$ касательная составляющая центробеж

ной силы, Н;

$3 \cdot 1$ - ширина двух крышек ячеек сота, м.

Так как распределенная нагрузка зависит от ширины крышек ячеек сота, то можно записать, что

$q\left(z_{3}\right)=\frac{F_{\text {цб }}^{\tau}}{z_{3}}$

Рассмотрим сечение крышки ячейки сота на протяжении $0<z 3<1$

$\Sigma \mathrm{z}_{3}=0 \quad N_{3}=q\left(\mathrm{z}_{3}\right) \mathrm{z}_{3}$

Нормальное напряжение при растяжении крышки ячейки сота определим по фрормуле:

$\sigma_{3}=\frac{N_{3}}{\mathrm{~A}_{\mathrm{\kappa p}}}$

где $\mathrm{N}_{3}$ - продольная сила, $\mathrm{H}$;

$A_{\text {кр }}$ площадь поперечного сечения крышки ячейки сота, м².

При $\mathrm{z}_{3}=0 ; \mathrm{N}_{3}=0 ; \sigma_{3}=0$

При $\quad \mathrm{z}_{3}=l ; \mathrm{N}_{3}=F_{\text {ц } 6}^{\tau} ; \sigma_{3}=\frac{N_{3}}{\mathrm{~A}_{\mathrm{\kappa р}}}=\frac{F_{\text {цб }}^{\tau}}{l \cdot S_{\mathrm{Kр}}}$

Построим в программе Mathcad 15 зависимость напряжений, возникающих в крышках ячеек сота, от угловой скорости ротора на основании уравнения 25 (рис. 7).

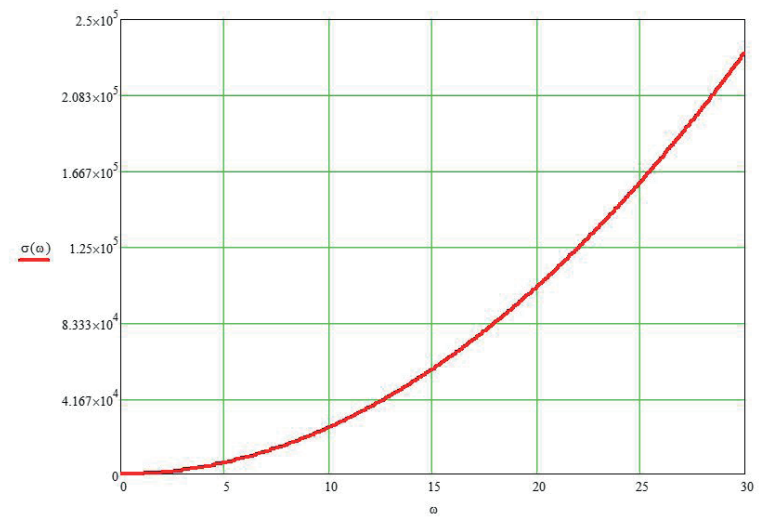

Рис. 7 - Зависимость напряжений б3 (Па), возникающих в крышках ячеек сота, от угловой скорости $\omega$ (рад/с) ротора комплексного агрегата

Анализ рисунка 7 показывает, что нагрузка на крышки ячейки сопоставима с нагрузками на стенки ячейки при вертикальном расположении сота. Таким образом, при скарификации крышки ячейки обладают достаточной прочностью, и для их разрыва требуется значительное увеличение угловой скорости вращения ротора.

При откачке меда на интенсивных режимах и скарификации перговых сотов возможно прогибание восковой основы сотов, которое может приводить к деформации и разрыву стенок ячеек, поэтому необходимо уточнить радиусы кривизны, приводящие к деформации ячейки и разрыву стенки ячейки. Для обеспечения требуемых про- 
гибов восковой основы сотов были изготовлены деревянные шаблоны с радиусом кривизны 0,45; 0,$50 ; 0,55 ; 0,60 ; 0,65 ; 0,70 ; 0,75 ; 0,80$ м (рис.8).

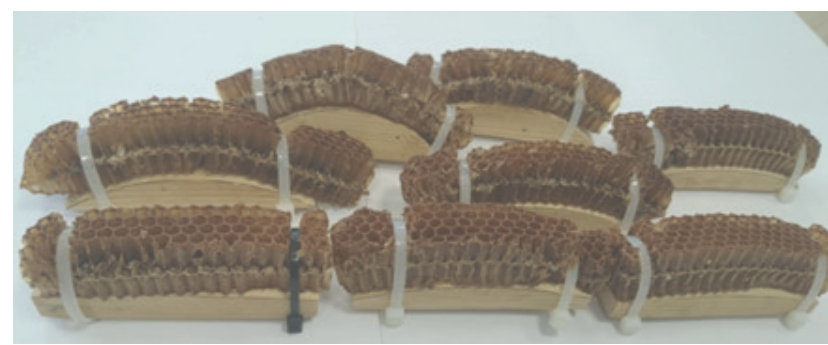

Рис. 8 - Формы для прогиба восковой основы сотов

Обследование состояния поверхности стенок ячеек сота и их разрывы фриксировались при помощи электронного микроскопа марки Альтами MET 1M.

Было обследовано 10 ячеек каждого образца. В результате установлено, что при радиусе кривизны менее 0,55 метра наблюдались глубокие разрывы стенок ячеек, которые показаны на рисунке 9. Также следует отметить, что при сжатии ячеек с обратной стороны сота разрывов и существенных деформаций не наблюдалось. Это можно обьяснить большей прочностью воска на сжатие, чем на разрыв.

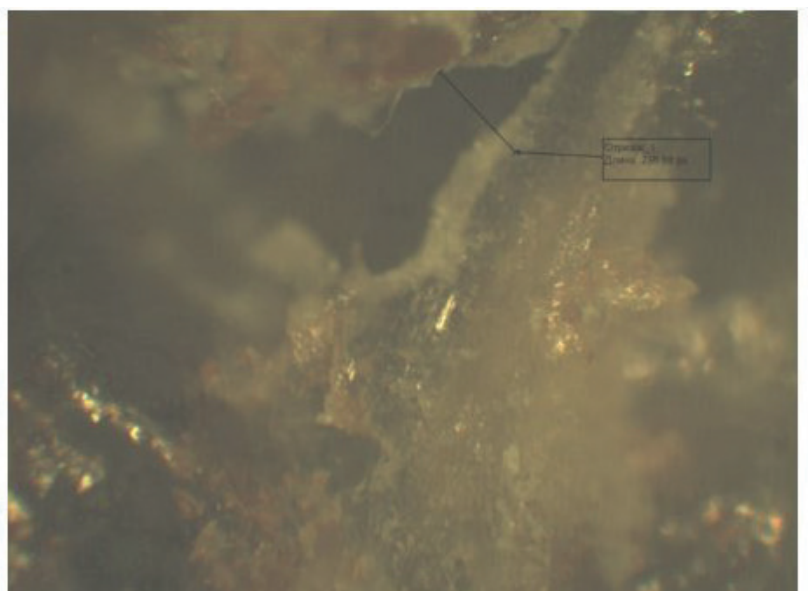

Рис. 9 - Общий вид разрыва стенки ячейки при изгибе сота радиусом кривизны 0,55 м

Анализируя рисунок 9, можно видеть, что разрыв стенок ячеек происходит с наружной стороны сота, что согласуется с действием максимальных нормальных напряжений (уравнение (21)).

На основании проведенных теоретических исследований выявлено, что разрушение ячеек сота зависит от направления приложения нагрузки. Нагрузка на стенки ячеек почти в 2 раза меньше при горизонтальной установке сота в ротор центрифуги, чем при вертикальной.

Скарификацию сотов целесообразнее проводить вдоль армирующих проволок сота по ширине рамки, а при откачке меда следует ограничивать угловую скорость ротора вертикально расположенных рамок для снижения нагрузки и исключения повреждения ячеек пчелиных сотов. Также установлено, что процесс скарификации перговых сотов целесообразно производить в специальных кассетах, позволяющих обеспечить прогиб с радиус кривизны около 0,55 м.

\section{Выводы}

Теоретические исследования усилий растяжения, возникающих в ячейках сота, позволили установить, что наибольшие усилия возникают при вертикальном расположении сота в роторе центрифуги, и при откачке меда из сотов следует ограничивать угловую скорость ротора до 20 рад/с для снижения нагрузки и исключения повреждения ячеек вертикально установленных пчелиных сотов. При угловой скорости 26 рад/с растягивающие напряжения при вертикальном расположении сота составляют 3,479*105 Па - почти в 1,73 раза выше, чем при горизонтальном положении - 2,009*105 Па, и может привести к разрыву восковых пластинок ячеек. Для исключения неравномерности образования разрывов стенок ячеек перговых сотов скарификацию центробежными силами целесообразнее проводить вдоль армирующих проволок сота по ширине рамки, при этом рекомендуется применять специальные кассеты, позволяющие обеспечить одинаковый радиус кривизны сота около $0,55 \mathrm{~m}$.

\section{Список литературы}

1.Мамонов, Р.А. Свойства меда и сотов необходимые для конструирования комплексного агрегата / Р.А. Мамонов, А.М. Афранасьев, М.Ю. Афанасьев // Пчеловодство. - 2017. - № 7. - С. 39-41.

2. Некрашевич, В.Ф. Комбинированный агрегат для переработки пчеловодной продукции / В.Ф. Некрашевич, А.А. Курочкин, А.М. Афранасьев // Пчеловодство. - 2016. - № 5. - С. 48-49.

3. Патент № 2472340 Российская Федерация, МПК А01К 59/00. Способ скарификации перговых сотов / В.Ф. Некрашевич, Р.А. Мамонов, М.В. Коваленко (РФ); заявитель и патентообладатель ФГОУ ВПО Рязанский ГАТУ. - Заявка 2011123184/13 от 08.06.2011; опубл. 20.01.2013, Бюл. № 2. (1стр.).

4. Патент № 2615832 Российская Федерация, МПК А01К 59/00. Комбинированный агрегат для откачки мёда, скарификации перговых сотов и выделения воскоперговой массы из сотов. / В.Ф. Некрашевич, Р.А. Мамонов, Т.В. Торженова, А.М. Афранасьев; заявитель и патентообладатель ФГБОУ ВПО Рязанский ГАТУ. - Заявка 2016115950 от 22.04.2016; опубл. 11.04.2017. Бюл. №11. (9 стр.).

5. Патент № 2498178 Российская Федерация, МПK F26B9/06. Устройство для сушки перговых сотов / В.И. Курдюмов, А.В. Журавлев; Заявитель и патентообладатель ФГБОУ ВПО Ульяновская ГСХА. - Заявка № 2012122841/06 от 01.06.2012; Опубликовано 10.11.2013 Бюл. № 31. (4 стр.).

6. Патент № 2549380 Российская Федерация, МПK F26B15/04. Устройство для сушки перговых сотов / В.И. Курдюмов, А.А. Павлушин, А.В. Журавлѐв; Заявитель и патентообладатель ФГБОУ ВПО Ульяновская ГСХА. - Заявка 2014116334/06 от 22.04.2014 опубл. 27.04.2015, Бюл. №12. (5 стр.).

7. Некрашевич, В.Ф. Исследование прочностных свойств восковой основы сотов / В.Ф. Некрашевич, Р.А. Мамонов, А.М. Афанасьев, М.Ю. 
Афранасьев, М.Ю. Костенко, А.В. Шемякин // Пчеловодство. - 2020. - № 1. - С. 46-48.

8. Tarasov, D. Mathematical modeling of deformations of flexible threads under their dynamic loading in the zone of material plasticity / D. Tarasov, V. Konovalov, V. Zaitsev, Y. Rodionov // Journal of Physics: Conference Series 2019. C. 012014.

9. Журавлев, А.В. К вопросу очистки рамок от воскового сырья центробежными силами / А.В. Журавлев, С.А. Сутягин, В.И. Курдюмов // Вестник Рязанского ГАТУ им. П.А. Костычева. - 2015. - № 4 (28). - С. 83-85.

10. Мамонов, Р.А. Теория процесса центробежной скарификации пчелиных сотов / Р.А. Мамонов // Вестник Рязанского ГАУ им. П.А. Костычева. 2018. - № 2 (38). - С. 102-107.

\section{RESEARCH OF STRENGTH OF CELLS AT BENDING OF BEE CELL}

Afanasyev Alexander M., applicant for the Department of Metal Technology and Machine Repair

Kostenko Mikhail Yu., Doctor of Technical Sciences, Associate Professor, Professor of the Department of Metal Technology and Machine Repair, Km340010@rambler.ru

Afanasyev Mikhail Yu., candidate of agricultural sciences, associate professor, associate professor of the Department of Electrical Engineering and Physics

Ryazan State Agrotechnological University named after P.A. Kostycheva

Mamonov Roman A., doctor of technical sciences, associate professor, professor of the logistics department of the penal system, FKOU VO "Academy of Law and Management of the Federal Service for the Execution of Appointment", mamonov.agrotexnol@yandex.ru

The high profitability of obtaining beekeeping products depends on the efficient use of bee honeycombs in the technology of keeping bees, as well as obtaining beekeeping products. During the pumping out of honey, part of the honeycomb frames are rejected due to deformation of the honeycomb structure, the formation of cracks and tears in it. To replenish the rejected honeycombs, one has to additionally purchase sheets of wax, waste time and spend the potential of the bee family on rebuilding the structure of the honeycomb frames. We have studied the effects of centrifugal forces on the honeycomb structure with various methods of placing the honeycomb frame in the centrifuge rotor. Using the method of cutting knots, the forces arising in the nodes of the hexagonal cell of the honeycomb were found. With an increase in the angular velocity of rotation of the rotor, the tensile load on the honeycomb cells increases intensively. At an angular velocity of 26 rad / s, tensile stresses at a vertical location of the honeycomb are 3.479*105 almost 1.73 times higher than at a horizontal position of 2.009 * $105 \mathrm{~Pa}$, and can lead to rupture of the wax plates of the cells. Ultimate tensile stresses of $200 \mathrm{kPa}$ are achieved at an angular velocity above $26 \mathrm{rad} / \mathrm{s}$. Therefore, when pumping honey, you should limit the speed of rotation of vertically arranged frames to reduce the load and eliminate damage to honeycomb cells, especially at the beginning of the process of pumping honey. An analysis of the obtained equations established that an increase in the angular velocity above 26 rad / s leads to a progressive increase in the normal stresses in the cells of the cell. With a vertical arrangement of the honeycomb in the centrifuge rotor, the ultimate breaking loads of the honeycomb cells occur at a lower rotational speed. It was revealed that the formation of cracks depends on the radius of curvature of the honeycomb structure and should be about 0.55 $m$ for scarification of perch honeycombs.

Key words: honey separators, honeycomb frames, beekeeping products, pumping out honey, bee bread, scarification of bee honeycombs, honeycomb cells.

\section{Literatura}

1.Mamonov, R.A. Svojstva meda i sotov neobhodimye dlya konstruirovaniya kompleksnogo agregata / R.A. Mamonov, A.M. Afanas'ev, M.YU. Afanas'ev // Pchelovodstvo. - 2017. - № 7. - S. 39-41.

2. Nekrashevich, V.F. Kombinirovannyj agregat dlya pererabotki pchelovodnoj produkcii /V.F. Nekrashevich, A.A. Kurochkin, A.M. Afanas'ev // Pchelovodstvo. - 2016. - № 5. - S. 48-49.

3. Patent № 2472340 Rossijskaya Federaciya, MPK A01K 59/00. Sposob skarifikacii pergovyh sotov / V.F. Nekrashevich, R.A. Mamonov, M.V. Kovalenko (RF); zayavitel' i patentoobladatel' FGOU VPO Ryazanskij GATU. - Zayavka 2011123184/13 ot 08.06.2011; opubl. 20.01.2013, Byul. № 2. (1str.).

4. Patent № 2615832 Rossijskaya Federaciya, MPK A01K 59/00. Kombinirovannyj agregat dlya otkachki myoda, skarifikacii pergovyh sotov i vydeleniya voskopergovoj massy iz sotov. / V.F. Nekrashevich, R.A. Mamonov, T.V. Torzhenova, A.M. Afanas'ev; zayavitel' i patentoobladatel' FGBOU VPO Ryazanskij GATU. Zayavka 2016115950 ot 22.04.2016; opubl. 11.04.2017. Byul. №11. (9 str.).

5. Patent № 2498178 Rossijskaya Federaciya, MPK F26B9/06. Ustrojstvo dlya sushki pergovyh sotov / V.I. Kurdyumov, A.V. ZHuravlev; Zayavitel' i patentoobladatel' FGBOU VPO Ul'yanovskaya GSKHA. - Zayavka № 2012122841/06 ot 01.06.2012; Opublikovano 10.11.2013 Byul. № 31. (4 str.).

6. Patent № 2549380 Rossijskaya Federaciya, MPK F26B15/04. Ustrojstvo dlya sushki pergovyh sotov / V.I. Kurdyumov, A.A. Pavlushin, A.V. ZHuravlèv; Zayavitel' i patentoobladatel' FGBOU VPO UI'yanovskaya GSKHA. - Zayavka 2014116334/06 ot 22.04.2014 opubl. 27.04.2015, Byul. №12. (5 str.).

7. Nekrashevich, V.F. Issledovanie prochnostnyh svojstv voskovoj osnovy sotov / V.F. Nekrashevich, R.A. 
Mamonov, A.M. Afanas'ev, M.YU. Afanas'ev, M.YU. Kostenko, A.V. SHemyakin // Pchelovodstvo. - 2020. - № 1. - S. 46-48.

8. Tarasov, D. Mathematical modeling of deformations of flexible threads under their dynamic loading in the zone of material plasticity / D. Tarasov, V. Konovalov, V. Zaitsev, Y. Rodionov // Journal of Physics: Conference Series 2019. S. 012014.

9. ZHuravlev, A.V. K voprosu ochistki ramok ot voskovogo syr'ya centrobezhnymi silami / A.V. ZHuravlev, S.A. Sutyagin, V.I. Kurdyumov // Vestnik Ryazanskogo GATU im. P.A. Kostycheva. - 2015. - № 4 (28). - S. 83-85.

10. Mamonov, R.A. Teoriya processa centrobezhnoj skarifikacii pchelinyh sotov / R.A. Mamonov // Vestnik Ryazanskogo GAU im. P.A. Kostycheva. - 2018. - № 2 (38). - S. 102-107.

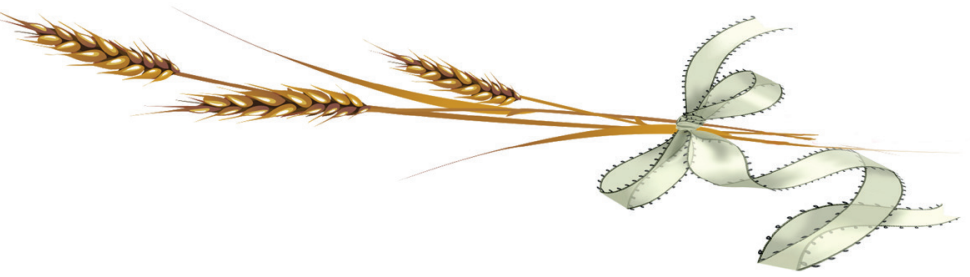

УДК 621.362

DOI 10.36508/RSATU.2020.45.1.013

\section{К ВОПРОСУ ИССЛЕДОВАНИЯ КПД ЭЛЕМЕНТОВ ПЕЛЬТЬЕ}

Бышов Дмитрий Николаевич, канд. техн. наук, доцент кафедры эксплуатации машинно-тракторного парка, university@rgatu.ru

КАШИРИн Дмитрий Евгеньевич, д-р техн. наук, доцент, зав кафр. «Электроснабжение», kadm76@mail.ru

ГОБЕЛЕВ Сергей Николаевич, канд. Техн. наук, доцент кафредры «Электроснабжение», university@rgatu.ru

БОчкоВ Павел Эдуардович, магистрант кафедры «Электроснабжение», pav.bochkov@yandex.ru

ПАВЛОВ Виктор Вячеславович, аспирант кафедры «Электроснабжение», vikp76@mail.ru

Рязанский государственный агротехнологический университет имени П.А. Костычева

В процессе сушки продуктов сельского хозяйства, в частности, продуктов пчеловодства, часто возникает необходимость удаления влаги из теплоносителя (воздушного потока). Эфффективное решение этой задачи может быть достигнуто путём использования элементов Пельтье. Элементы Пельтье - это полупроводниковые тепловые насосы, то есть устройства, позволяющие получать отрицательные температуры при протекании через них электрического тока. Для создания эфрфективных сушильных установок нами были определены рациональные условия электрического питания этих устройств, в частности, род тока и величина потребляемой мощности, обеспечивающие наилучшие значения КПД устройства. Лабораторные исследования проводили в два этапа: исследование мощностных характеристик элемента Пельтье при подключении его к блоку питания, генерирующему постоянный электрический ток; исследование мощностных характеристик элемента Пельтье при подключении к специализированному блоку питания. В качестве опытного образца был исследован элемент Пельтье марки «TEC1-12705». В статье описана методика проведения исследований, структурная и электрическая схемы лабораторной установки, а также её общий вид. По результатам исследования были получены математические модели и графрические зависимости разницы температур $\Delta t$ от потребляемой мощности Р. Полученные результаты позволили установить количественные характеристики исследуемых процессов.

Ключевые слова: элемент Пельтье, блок питания, фрорма тока, разница температур.

\section{Введение}

Элемент Пельтье - это термоэлектрический преобразователь, принцип действия которого заключается в возникновении разницы температур при протекании через него электрического тока. Элементы Пельтье широко применяется для создания портативных холодильных установок, для конденсации влаги из воздуха, циркулирующего в сушильных установках, а также в качестве датчиков, регистрирующих перепад температуры. Современный элемент Пельтье представляет собой керамическую пластину толщиной от 2 мм до 5 мм и площадью от $4 \mathrm{~cm}^{2}$ до $36 \mathrm{~cm}^{2}$, внутри которой расположены полупроводниковые спаи, включённые последовательно. При подаче электрического тока на элемент Пельтье он превращается в тепловой насос. Одна его сторона охлаждается, а другая нагревается. При этом, используя различные комбинации элементов Пельтье, можно добиться практически криогенных температур.

Элементы Пельтье имеют свойства обратимости, то есть при перепаде температуры на его поверхностях устройство генерирует термо-ЭДС. Главным преимуществом элемента Пельтье перед другими системами охлаждения является долгий срок службы (20000 часов), бесшумность работы, малые габариты при достаточно большой мощности отвода тепла.

Нами исследуется возможность использования элементов Пельтье для осушения воздуха при его

() Бышов Д. Н., Каширин Д. Е., Гобелев С. Н.,Бочков П. Э., Павлов В. В., 2020 г. 
циркуляции в сушильной установке, используемой, в частности, в технологии извлечения перги из пчелиных сотов [1-5]. Процесс осушения теплоносителя (выделения влаги) [6, 7, 8] позволяет существенно сократить продолжительность сушки продукции сельского хозяйства, в частности, пчеловодства [9-11], и, как следствие, снизить энергоёмкость этого процесса [12-14]. При прохождении потока воздуха по охлаждённой поверхности элемента Пельтье вода в виде капель конденсируется, после чего удаляется специальным устройством.

В связи с вышесказанным, цель исследования заключалась в обосновании параметров питания элементов Пельтье, обеспечивающих наилучшие показатели их КПД [15-18].

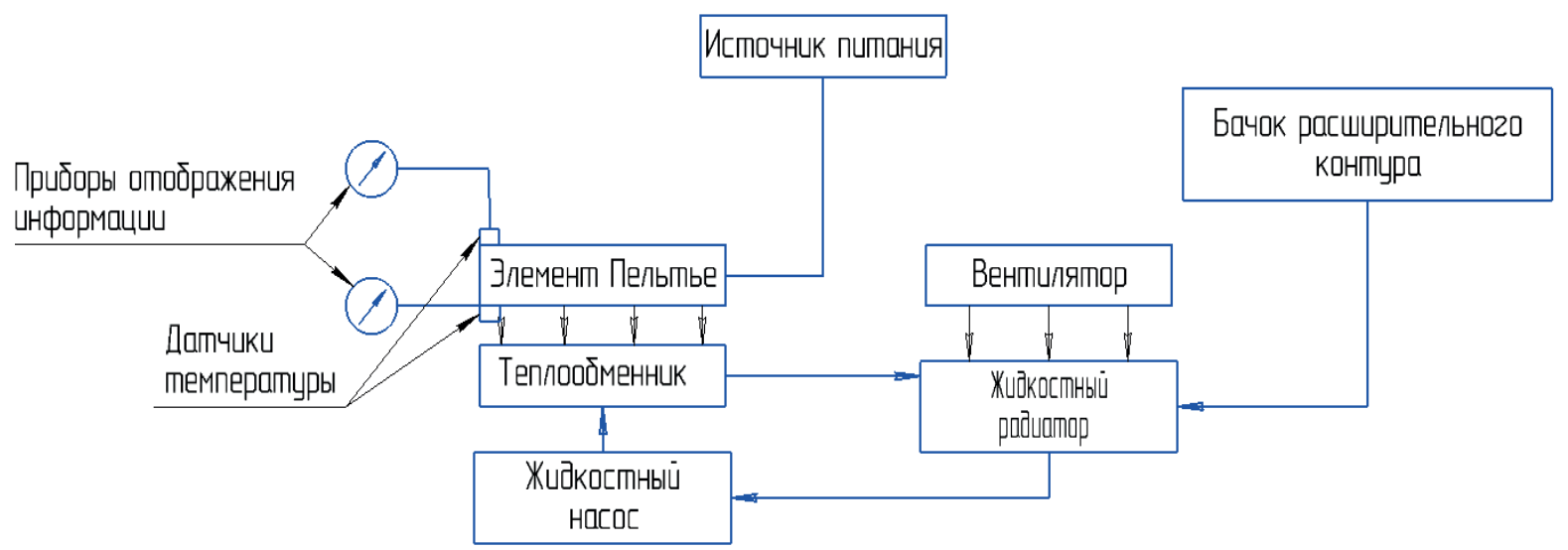

Рис. 1 - Структурная схема лабораторной установки для исследования элемента Пельтье

6

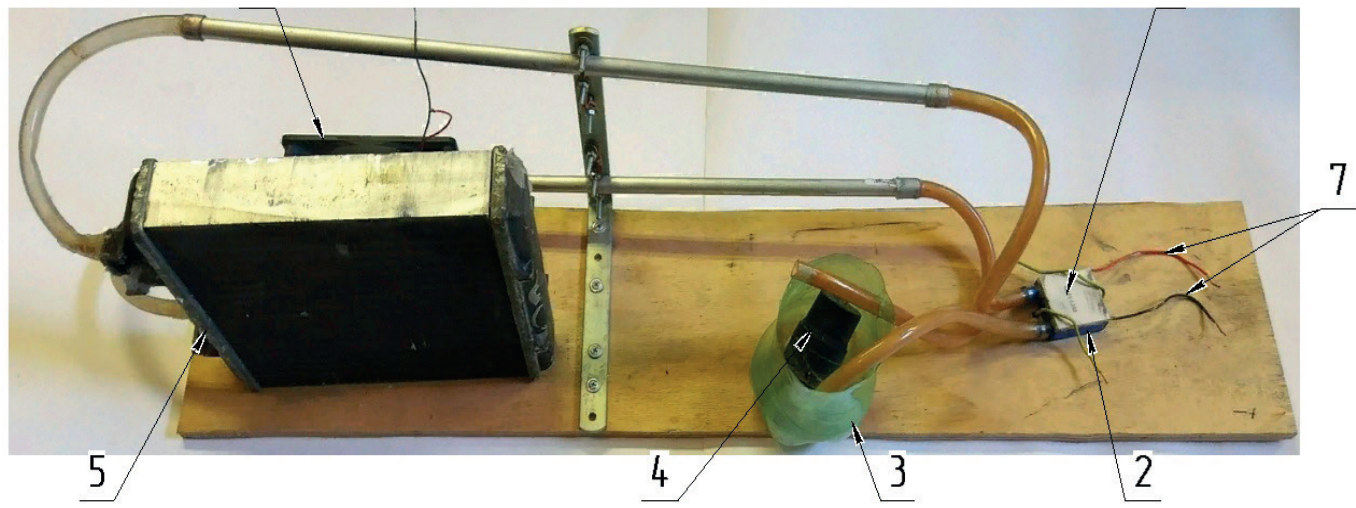

1 - элемент Пельтье; 2 - теплообменник; 3 - расширительный бак; 4 - жидкостной циркуляционный насос; 5 - радиатор; 6 - вентилятор; 7 - провода питания элемента Пельтье

Рис. 2 - Общий вид системы жидкостного охлаждения

К внешней нагреваемой стороне элемента Пельтье и к его охлаждающей поверхности посредством термопасты прикреплены два датчика температуры марки «MOSEKO-TR101», позволяющие проводить измерения с точностью до $\pm 0,5{ }^{\circ} \mathrm{C}$.

Первый этап исследования предполагал изучение работы элемента Пельтье от блока питания, выполненного по классической схеме, пред- ставленной на рисунке 3. Режим перекачки тепла контролировали по показаниям термодатчиков. Запись параметров напряжения, тока и мощности, потребляемой элементами Пельтье, а также перепады температур производили после выхода системы на стационарный режим работы. Напряжение, подаваемое на исследуемый элемент, в ходе опытов меняли с шагом в 1 вольт 


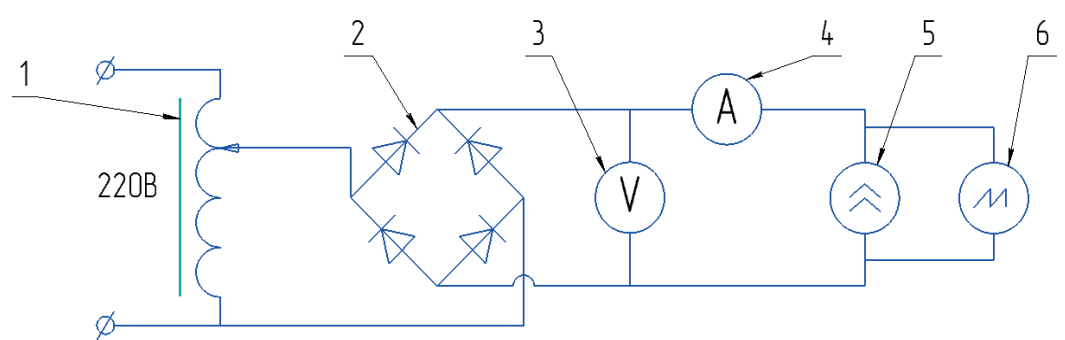

1 - ЛАТР; 2 - диодный мост; 3 - вольтметр; 4 - амперметр; 5 - элемент Пельтье; 6 - осциллограф

Рис. 3 - Схема блока питания постоянного тока

Данная электрическая схема проста в изготовлении, при этом имеет на выходе постоянный пульсирующий ток с частотой 100 Гц. Это значит, что ток постоянно изменяет своё значение, достигая при этом нуля.

На втором этапе исследований использовали блок питания марки Power man (модель IPP450DJ2-0), на выходе которого генерируется сглаженный электрический ток. Величину напряжения блока питания изменяли посредством реостата с шагом в 1 вольт. Результаты также регистрировали при выходе системы на стационарный режим работы.

Опыты в каждой точке проводили с трёхкратной повторностью.

В общем случае порядок проведения опыта был следующим: перед включением питания элемента Пельтье приводили в действие на 5 минут систему жидкостного охлаждения для выравнивания температуры теплоносителя и воздуха в помещении, где проводился опыт. Производили контроль точности цифровых термометров.

На первом этапе при помощи ЛАТРа устанавливали напряжение, равное $\mathrm{U}=1 \mathrm{~B}$. После этого таймером отмеряли интервал времени 5 минут для выравнивания температур и обеспечения доверительного интервала в 95\%. Для первого этапа напряжение повышали с $U=1 \mathrm{~B}$ до $U=16 \mathrm{~B}$ с шагом в 1В каждые 5 минут.

На втором этапе при включении элементов Пельтье от блока питания Power man оказалось невозможным обеспечить начало измерений с напряжения $\mathrm{U}=1 \mathrm{~B}$. При добавлении в цепь реостата удалось достичь минимального напряжения $\mathrm{U}=6,75 \mathrm{~B}$, которое повышали до максимального $\mathrm{U}=11,76 \mathrm{~B}$ также $\mathrm{c}$ шагом в $1 \mathrm{~B}$ каждые 5 минут.

Во время проведения всех опытов записывали показания термометров и амперметра.

После испытаний по полученным данным была вычислена потребляемая мощность Р, Вт после каждого повышения напряжения по фрормуле:

$P=I \cdot U$

где I - ток, $A$; $U$ - напряжение, $\mathrm{B}$.

Также определена разница температур между горячей и холодной сторонами элемента Пельтье:

$\Delta \mathrm{t}=\mathrm{t}_{\text {гор }}-\mathrm{t}_{\text {хол }}$

где $t_{\text {rop }}$ - температура на горячей стороне элем (2) та Пельтье, ${ }^{\circ} \mathrm{C}$; $\mathrm{t}_{\text {хол }}$ - температура на холодной стороне элемента Пельтье, ${ }^{\circ} \mathrm{C}$.

\section{Результаты и их анализ}

В результате статистической обработки результатов исследования удалось установить математическую модель, описывающую зависимость эффрективности теплопередачи элемента Пельтье от потребляемой мощности от источника постоянного электрического тока, представленную полиномом вида:

$\Delta t(P)=6.08+1.94 \cdot P-0.1 \cdot P^{2}+0.002 \cdot P^{3}-1.41 \cdot 10^{-5} \cdot P^{4}$,

$R^{2}=0.951$

где $\mathrm{P}$ - потребляемая мощность, Вт.

Данная зависимость представлена графически на рисунке 4. В полученной модели обнаруживается явный экстремум.

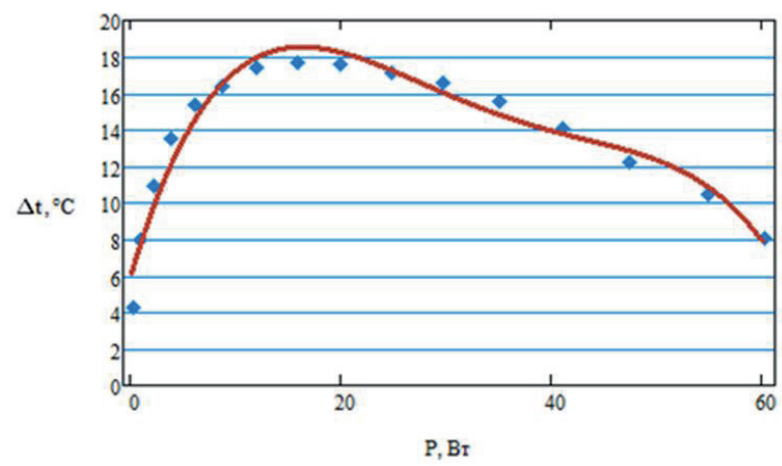

температур от потребляемой мощности для опыта с блоком питания, генерирующим постоянный электрический ток

Эфффективность теплопередачи элемента Пельтье, питаемого сглаженным электрическим током, с наибольшей точностью описывает квадратичное уравнение (4), представленное в виде графической зависимости на рисунке 5.

$$
\mathrm{I} \Delta \mathrm{t}(\mathrm{P})=14.34+0.65 \cdot P-0.012 \cdot \mathrm{P}^{2}, \quad \mathrm{R}^{2}=0.987
$$

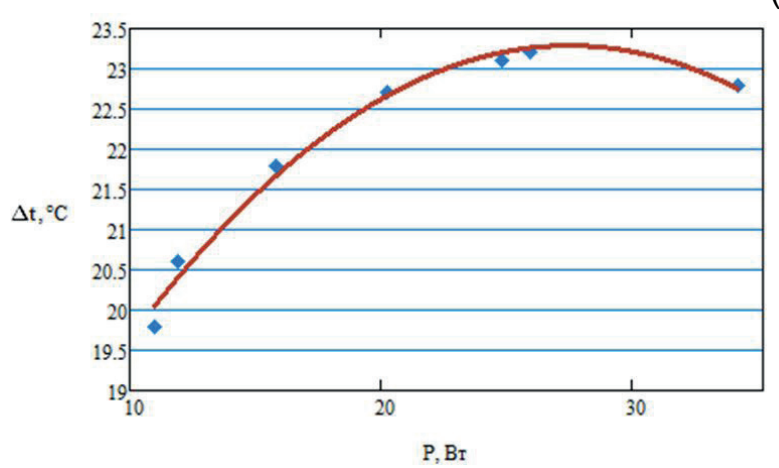

Рис. 5 - Графическая зависимость разницы температуры от потребляемой мощности при

питании элемента Пельтье сглаженным электрическим током.

Анализ представленных зависимостей показы- 
вает, что в первом исследовании элемент Пельтье достигает максимального КПД при потребляемой мощности $\mathrm{P}=15,76$ Вт. Второй этап исследований показывает, что наилучшие показатели элемент Пельтье выдаёт при мощности $\mathrm{P}=28,8$ Вт.

\section{Выводы}

Анализ результатов проведенного исследования позволяет утверждать, что КПД элемента Пельтье зависит как от величины потребляемой им мощности, так и от рода питающего тока. Причём установленные зависимости имеют явные экстремумы. Полученные закономерности можно объяснить физическими процессами, происходящими в спаях элемента Пельтье: при увеличении потребляемой мощности происходит увеличение значения разницы температур до определённого уровня, а при её увеличении свыше предельного значения количество вырабатываемой теплоты оказывается выше поглощаемой на холодной стороне элемента Пельтье, что ведёт к снижению КПД. Аналогичная зависимость подтверждается и при питании элемента Пельтье сглаженным электрическим током.

Вторым существенным фрактором оказался род тока, питающего элемент Пельтье, в частности, при сглаженном токе можно достичь большей разницы температур при том же значении потребляемой мощности, то есть значительно увеличить КПД. Данное явление связанно со свойствами полупроводников, значимое влияние на которые оказывает плотность тока.

\section{Литература}

1. Бышов Д.Н. Исследование работы измельчителя воскового сырья / Д.Н. Бышов, И.А. Успенский, Д.Е. Каширин, Н.В. Ермаченков, В.В. Павлов // Сельский механизатор. - 2015. - № 8. - С. 28-29.

2. Бышов Д.Н. Исследование рабочего процесса измельчителя перговых сотов / Д.Н. Бышов, Д.Е. Каширин, Н.В. Ермаченков, В.В. Павлов // Вестник Красноярского государственного аграрного университета. - 2015. - № 8. - С. 155-159.

3. Бышов Н.В. Исследование рабочего процесса вибрационного решета при просеивании воскоперговой массы / Н.В. Бышов, Д.Е. Каширин // Вестник Красноярского государственного аграрного университета. - 2013. - С. 160-162.

4. Бышов Н.В. Исследование установки для извлечения перги из сотов / Н.В. Бышов, Д.Е. Каширин // Механизация и электрификация сельского хозяйства. - 2012. - № 2. - С. 31-32.

5. Бышов Н.В. Обоснование параметров измельчителя перговых сотов / Н.В. Бышов, Д.Е. Ка- ширин // Механизация и электрификация сельского хозяйства. - 2012. - № 1. - С. 29-30.

6. Бышов Н.В. Обоснование рациональных параметров измельчителя перговых сотов/Н.В. Бышов, Д.Е. Каширин // Вестник Красноярского государственногоуниверситета. -2012. №6.-С. 134-138.

7. Каширин Д.Е. Вакуумная сушка перги / Д.Е. Каширин // Пчеловодство. - 2006. - № 4. - С. 50.

8. Каширин Д.Е. Исследование массы и геометрических параметров перги и перговых сотов / Д.Е. Каширин // Вестник Красноярского государственного аграрного университета. - 2010. - № 5. - C. $152-154$.

9. Каширин Д.Е. Исследование некоторых прочностных характеристик восковой основы пчелиных сотов / Д.Е. Каширин, А.В. Куприянов // Вестник Красноярского государственного аграрного университета.- 2011.- № 8. - С. 199-202.

10. Каширин Д.Е. Исследование рабочего процесса измельчителя перговых сотов / Д.Е. Каширин // Вестник Федерального государственного образовательного учреждения высшего профрессионального образования Московский государственный агроинженерный университет им. В.П. Горячкина. - 2010. - № 1. - С. 24-27.

11. Каширин Д.Е. К вопросу отделения перги из измельчённой воскоперговой массы / Д.Е. Каширин // Вестник Красноярского государственного аграрного университета. - 2010. - № 1. - С. 138-140.

12. Каширин Д.Е. Конвективная сушка перги / Д.Е. Каширин//Пчеловодство. - 2009.-№ 8-С. 46-47.

13. Каширин Д.Е. Способ и устройство для извлечения перги / Д.Е. Каширин // Аграрный научный журнал. - 2010. - № 5. - С. 34-36.

14. Каширин Д.Е. Технология и устройство для измельчения перговых сотов / Д.Е. Каширин // Диссертация на соискание ученой степени кандидата технических наук / Рязань. - 2001.

15. Каширин Д.Е. Технология и устройство для измельчения перговых сотов / Д.Е. Каширин // Диссертация на соискание ученой степени кандидата технических наук / Рязань. - 2001.

16. Пат. № 2391610 РФ. Установка для сушки перги / Д.Е. Каширин. - Заявл. 16.03.2009; опубл. 10.06.2010, бюл. № 16. - 7с.

17. Пат. № 2391610 РФ. Установка для сушки перги / Д.Е. Каширин. - Заявл. 16.03.2009; опубл. 10.06.2010, бюл. № 16. - 7с.

18. Пат. № 2275563 РФ. F26B 21/04. Установка для сушки перги в сотах / Д.Е. Каширин. - Заявл. 29.11.2004; опубл. 27.04.2006, бюл. № 12. - 5с.

\title{
RESEARCH EFFICIENCY OF PELTIER ELEMENTS
}

\author{
Byshov Dmitriy N., candidate of technical sciences, associate professor, university@rgatu.ru \\ Kashirin Dmitriy Ye., doctor of technical sciences, associate professor, kadm76@mail.ru \\ Gobelev Sergey N., candidate of technical sciences, associate professor, university@rgatu.ru \\ Bochkov Pavel E., graduate student, pav.bochkov@yandex.ru \\ Pavlov Viktor V., post-graduate student, vikp76@mail.ru \\ Ryazan state agrotechnological University named after P. A. Kostychev
}

In the process of drying agricultural products, in particular beekeeping products, it is often necessary to remove moisture from the coolant (air flow). An effective solution to this problem can be achieved by using Peltier elements. Peltier elements are semiconductor heat pumps, that is, devices that allow to get negative 
temperatures when an electric current flows through them. To create efficient drying plants, we have determined the rational conditions for the electrical power supply of these devices, in particular, the type of current sort; the amount of power consumption, providing the best values of the efficiency of the device. Laboratory studies were carried out in two stages: the study of the power characteristics of the Peltier element when it was connected to a power supply unit that generated a direct electric current; study of the power characteristics of the Peltier element when connected from a specialized power supply. The Peltier element of the brand "TEC1-12705" was studied as a prototype. The article describes the methodology of research, structural and electrical circuits of the laboratory installation, as well as its general appearance. According to the results of the study, graphical dependences and mathematical models of the temperature difference $\Delta t$ from the power consumption were obtained. The Obtained results allowed to establish the quantitative characteristics of the studied processes.

Key words: Peltier element, power supply, current shape, temperature difference.

\section{Literatura}

1. Byshov D.N. Issledovanie raboty izmelchitelia voskovogo syria / D.N. Byshov, I.A. Uspenskii, D.E. Kashirin, N.V. Ermachenkov, V.V. Pavlov // Selskii mekhanizator. - 2015. - № 8. - S. 28-29.

2. Byshov D.N. Issledovanie rabochego protsessa izmelchitelia pergovykh sotov / D.N. Byshov, D.E. Kashirin, N.V. Ermachenkov, V.V. Pavlov // Vestnik Krasnoiarskogo gosudarstvennogo agrarnogo universiteta. - 2015. - № 8. - S. 155-159.

3. Byshov N.V. Issledovanie rabochego protsessa vibratsionnogo resheta pri proseivanii voskopergovoi massy / N.V. Byshov, D.E. Kashirin // Vestnik Krasnoiarskogo gosudarstvennogo agrarnogo universiteta. 2013. - S. 160-162.

4. Byshov N.V. Issledovanie ustanovki dlia izvlecheniia pergi iz sotov / N.V. Byshov, D.E. Kashirin // Mekhanizatsiia i elektrifikatsiia selskogo khoziaistva. - 2012. - № 2. - S. 31-32.

5. Byshov N.V. Obosnovanie parametrov izmelchitelia pergovykh sotov / N.V. Byshov, D.E. Kashirin // Mekhanizatsiia i elektrifikatsiia selskogo khoziaistva. - 2012. - № 1. - S. 29-30.

6. Byshov N.V. Obosnovanie ratsionalnykh parametrov izmelchitelia pergovykh sotov / N.V. Byshov, D.E. Kashirin // Vestnik Krasnoiarskogo gosudarstvennogo universiteta. - 2012. №6. - S. 134-138.

7. Kashirin D.E. Vakuumnaia sushka pergi / D.E. Kashirin // Pchelovodstvo. - 2006. - № 4. - S. 50.

8. Kashirin D.E. Issledovanie massy i geometricheskikh parametrov pergi i pergovykh sotov / D.E. Kashirin // Vestnik Krasnoiarskogo gosudarstvennogo agrarnogo universiteta. - 2010. - № 5. - S. $152-154$.

9. Kashirin D.E. Issledovanie nekotorykh prochnostnykh kharakteristik voskovoi osnovy pchelinykh sotov / D.E. Kashirin, A.V. Kupriianov // Vestnik Krasnoiarskogo gosudarstvennogo agrarnogo universiteta.- 2011.№ 8. - S. 199-202.

10. Kashirin D.E. Issledovanie rabochego protsessa izmelchitelia pergovykh sotov / D.E. Kashirin //Vestnik Federalnogo gosudarstvennogo obrazovatelnogo uchrezhdeniia vysshego professionalnogo obrazovaniia Moskovskii gosudarstvennyi agroinzhenernyi universitet im. V.P. Goriachkina. - 2010. - № 1. - S. $24-27$.

11. Kashirin D.E. K voprosu otdeleniia pergi iz izmelchennoi voskopergovoi massy / D.E. Kashirin //

Vestnik Krasnoiarskogo gosudarstvennogo agrarnogo universiteta. - 2010. - № 1. - S. 138-140.

12. Kashirin D.E. Konvektivnaia sushka pergi / D.E. Kashirin // Pchelovodstvo. - 2009.- № 8 - S. 46-47.

13. Kashirin D.E. Sposob i ustroistvo dlia izvlecheniia pergi / D.E. Kashirin // Agrarnyi nauchnyi zhurnal. 2010. - № 5. - S. 34-36.

14. Kashirin D.E. Tekhnologiia i ustroistvo dlia izmelcheniia pergovykh sotov / D.E. Kashirin // Dissertatsiia na soiskanie uchenoi stepeni kandidata tekhnicheskikh nauk / Riazan. - 2001.

15. Kashirin D.E. Tekhnologiia i ustroistvo dlia izmelcheniia pergovykh sotov / D.E. Kashirin // Dissertatsiia na soiskanie uchenoi stepeni kandidata tekhnicheskikh nauk / Riazan. - 2001.

16. Pat. № 2391610 RF. Ustanovka dlia sushki pergi / D.E. Kashirin. - Zaiavl. 16.03.2009; opubl. 10.06.2010, biul. № 16. - 7s.

17. Pat. № 2391610 RF. Ustanovka dlia sushki pergi / D.E. Kashirin. - Zaiavl. 16.03.2009; opubl. 10.06.2010, biul. № 16. - 7s.

18. Pat. № 2275563 RF. F26B 21/04. Ustanovka dlia sushki pergi v sotakh / D.E. Kashirin. - Zaiavl. 29.11.2004; opubl. 27.04.2006, biul. № 12. - 5s.

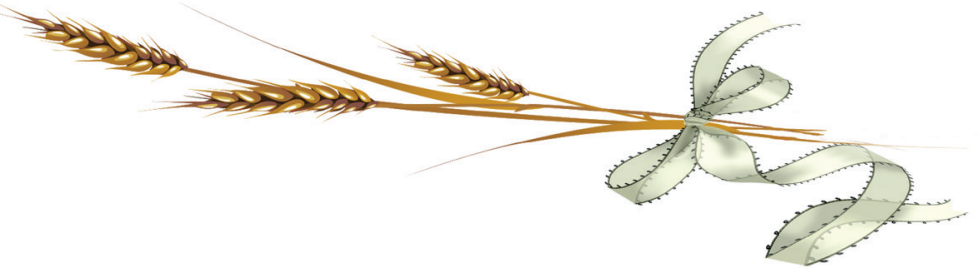


УДК 631.356

DOI 10.36508/RSATU.2020.45.1.014

ОБОСНОВАНИЕ ПАРАМЕТРОВ ПОПЕРЕЧНОГО ВОРОШИТЕЛЯ ПРУТКОВОГО ЭЛЕВАТОРА КАРТОФЕЛЕУБОРОЧНЫХ МАШИН

Бышов Николай Владимирович, д-р техн. наук, профрессор кафедры эксплуатации машиннотракторного парка, byshov63@mail.ru

РУзимУРОДОВ Абдугафор Абдусаторович, аспирант кафедры эксплуатации машинно-тракторного парка, gafor1213@mail.ru

липин Владимир Дмитриевич, канд. техн. наук, доцент кафедры технических систем в АПК, patent@rgatu.ru

Рязанский государственный агротехнологический университет имени П.А. Костычева

Качество уборки урожая картофреля напрямую зависит от конструкций рабочих органов картофелеуборочных машин. Для снижения затрат труда предлагается модернизация картофелеуборочных машин. Задачей модернизации пруткового элеватора картоффелекопателя является усиление разрушающего воздействия на клубненосный пласт, улучшение сепарации почвы и снижение потерь клубней картофеля. Для увеличения разрушающего воздействия на почвенные комки и улучшения сепарации почвы над каскадным прутковым элеватором устанавливается поперечный ворошитель, а снижение потерь картофеля происходит путем ограничения раскатывания клубней за картофрелекопателем с образованием валка клубней. Исследованиями установлено, что повышение эфрфрективности уборки картофреля зависит от работы сепарирующих устройств, а несовершенство конструкций их рабочих органов приводит к снижению производительности. В период уборки погодные условия могут быть настолько сложными, что техника не может выполнять свои ффункции. Поперечный ворошитель установлен над каскадным прутковым элеватором с возможностью изменения расстояния между ним и прутками элеватора. Для определения диаметра поперечного ворошителя и шага прутка проанализирована относительная скорость движения частиц почвы и представлены уравнения их движения. Получено математическое описание системы, которое позволяет определять оптимальные параметры устройства поперечного ворошителя, обеспечивая минимальные повреждения урожая и минимальные его потери с учетом размеров клубней, количества вороха и типа почвы.

Ключевые слова: картофелекопатель, поперечный ворошитель, прутковый элеватор, сепарация, лемех, повышение производительности, технологический процесс, совершенствование.

\section{Введение}

В настоящее время основными причинами недостаточной эфффективности картофелеводства являются следующие:

- применение малопроизводительной несовременной техники;

- проблемы механических повреждений клубней картофеля в процессе уборки;

- низкий технологический уровень возделывания картофеля.

Ключевая проблема по трудо- и энергозатратам для сбора урожая картофеля заключается в следующем:

- необходимость поднятия значительного по объему и массе пласта почвы;

- необходимость выделять клубни из данного пласта почвы;

- процесс сепарации клубней, т.е. отделение клубней от примесей, должен производиться с минимальными повреждениями.

Отметим, что доля повреждений клубней незначительна и составляет не более $2 \%$.

Исследованиями повышения эффективности механизации уборки картофеля, в целом, и работе сепарирующих устройств, в частности, посвящён ряд работ российских учёных [2, 3]. В этих работах отмечается, что современная техника для уборки картофеля не обеспечивает выполнения агротехнических требований, а несовершенство конструкций её рабочих органов приводит к снижению производительности. В период уборки погодные условия могут быть настолько сложными, что техника не может выполнять свои функции [2-5]. В работе И.Е. Кущева [4] отмечается, что на бесструктурных суглинистых почвах в процессе уборки образуются прочные почвенные комки, сопоставимые по размерам с клубнями. Перечисленные фракторы подчёркивают актуальность задачи повышения эффективности и качества функционирования сепарирующих рабочих органов картофелеуборочной техники.

\section{Материалы и методы исследований}

Повышения эффективности картофельного производства возможно добиться следующими способами:

- снижением затрат труда на единицу собранного урожая путем улучшения технологий возделывания и уборки;

- увеличением урожайности культуры.

Для снижения затрат труда предлагается модернизация картофелеуборочных машин, а именно сепарирующих рабочих органов, на которые приходится до 80\% отделенной почвы. Прутковые элеваторы являются наиболее применяемыми сепарирующими рабочими органами машин для уборки картофреля [6]. Тем не менее, их произво-

() Бышов Н. В., Рузимуродов А. А., Липин В. Д., 2020 г. 
дительность и необходимая полнота сепарации зависят от почвенно-климатических условий.

Задачей модернизации пруткового элеватора картофрелекопателя является усиление разрушающего воздействия на клубненосный пласт, улучшение сепарации почвы и снижение потерь клубней картофреля.

Для увеличения разрушающего воздействия на почвенные комки и улучшения сепарации почвы над каскадным прутковым элеватором устанавливается поперечный ворошитель, а снижение потерь картофеля происходит путем ограничения раскатывания клубней за картофрелекопателем с образованием валка клубней.

Картофрелекопатель снабжен поперечным ворошителем, установленным на каскадном прутковом элеваторе, и выполненным в виде приводного вала с фланцами. На приводном валу поперечного ворошителя между фланцами установлены спиралевидные пружины сжатия, навитые с просветом между витками с правой и левой навивкой. Спиралевидные пружины изготовлены из проволоки круглого сечения, а поверхности проволоки выполнены из эластичного материала, например силикона.

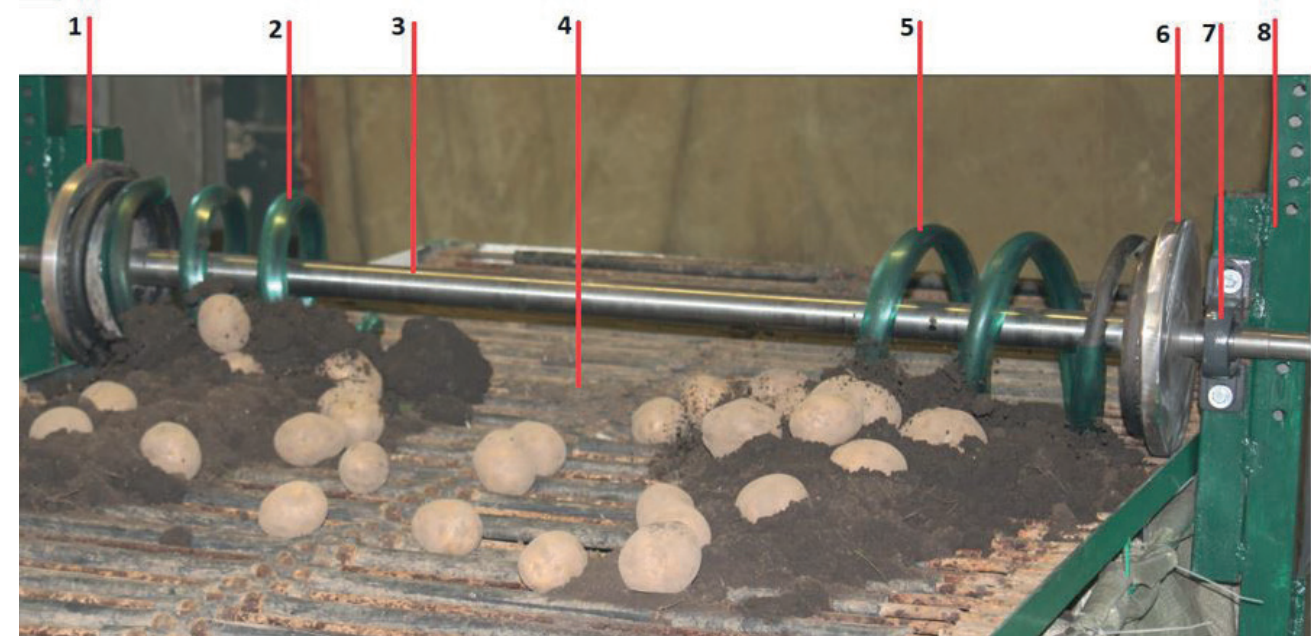

1-6 - фрланец; 2-5 - пружина с силиконовым покрытием; 3 - приводной вал; 4 - полотно элеватора;

7 - подщипник в корпусе; 8 - арка

Рис. 1 - Поперечный ворошитель

Поперечный ворошитель установлен над каскадным прутковым элеватором 4 с возможностью изменения расстояния между ним и прутками элеватора. Поперечный ворошитель выполнен в виде приводного вала 3 с фланцами 1 и 6 . На приводном валу 3 поперечного ворошителя между фланцами 1 и 6 закреплены спиральные пружины 2 и 5.

Спиральные пружины 2 и 5 навиты с просветом между витками, выполнены с правой и левой навивкой. Пружины 2 и 5 изготовлены из проволоки круглого сечения, поверхности проволоки пружин покрыты силиконовым шлангом.

При перемещении почвенных комков и клубней картофеля в зоне расположения поперечного ворошителя спиральные пружины 2 и 5, выполненные с правой и левой навивкой с просветом между витками, воздействуют на почвенные комки и
Картофелекопатель обеспечивает дополнительное разрушающее воздействие на почвенные комки с образованием за картофелекопателем картофельного валка. Основные особенности установки следующие:

1) поперечный ворошитель установлен над каскадным прутковым элеватором;

2) поперечный ворошитель установлен над каскадным прутковым элеватором с возможностью изменения расстояния между ним и прутками элеватора;

3) на приводном валу поперечного ворошителя между фоланцами установлены спиральные пружины сжатия;

4) спиральные пружины навиты с просветом между витками;

5) спиральные пружины выполнены с правой и левой навивкой;

6) спиральные пружины изготовлены из проволоки круглого сечения;

7) поверхности проволоки спиральной пружины выполнены из эластичного материала, например, силиконового шланга[1].На рисунке 1 представлен процесс сепарации на прутковом элеваторе с поперечным ворошителем в лабораторных условиях

\section{клубни картофеля.}

Клубни картофеля и почвенные комки под воздействием пружин 2 и 5 перемещаются к середине каскадного пруткового элеватора 4. При этом почвенные комки разрушается, и почва просеивается между прутками каскадного элеватора 4. Клубни картофеля очищаются от почвы спиральными пружинами 2 и 5, перемещаются на середину каскадного пруткового элеватора 4, а затем на почву без раскатывания за картофелекопателем, образуя валок.

\section{Обоснование геометрических параметров}

Проведем расчет параметров пружины картофелекопателя, работающего в тяжелых условиях.

При деформациях поперечный ворошитель накапливает потенциальную энергию, которая равна работе на заданном перемещении картофельного вороха. 
На основании наших исследований и научных источников выбрали три фактора: частота вращения и усилие поперечного ворошителя и линейная скорость полотна элеватора.

Скорость взаимодействия лопасти поперечного ворошителя с картофельным ворохом согласно [6]

$\vartheta_{\kappa}=\frac{\vartheta_{\ni} \cdot b_{\ni} \cdot h_{\ni}}{b_{\kappa} \cdot h_{\kappa}}$.

Примем рабочую скорость агрегата

$\vartheta_{\mathrm{\kappa}}=2,7 \quad \frac{\mathrm{\kappa м}}{\mathrm{u}}=0,75 \frac{\mathrm{M}}{\mathrm{c}}$.

Согласно [7], скорость элеватора:

$\vartheta_{\ni}=1,2 \cdot \vartheta_{\text {агр }}$.

Тогда:

$\vartheta_{\ni}=1,2 \cdot 0,75=0,9 \mathrm{~m} / \mathrm{c}$.

Произведем расчет скорости, приобретаемой ворохом после взаимодействия со средством интенсификации сепарации:

$$
\vartheta_{\mathrm{\kappa}}=\frac{0,9 \cdot 0,35 \cdot 0,06}{0,22 \cdot 0,05}=1,7 \mathrm{M} / \mathrm{c} \text {. }
$$

Для определения диаметра поперечного ворошителя и шага прутка проанализируем относительную скорость движения частиц почвы и представим уравнения их движения.

Дифференциальноеуравнениеввекторнойформе для относительного движения частицы почвы по рабочей поверхности устройства интенсификации: $\mathrm{m} \cdot \overline{\mathrm{a}}_{\mathrm{r}}=\sum \overline{\mathrm{F}}_{\mathrm{K}}+\bar{\Phi}_{\mathrm{C}}+\bar{\Phi}_{\mathrm{E}}$

где: $\overline{\mathrm{a}}_{\mathrm{r}}$ - ускорение относительного движения частицы;

$$
\sum \overline{\mathrm{F}}_{\mathrm{K}} \text { - геометрическая сумма всех сил, }
$$
действующих на частицу почвы с учетом реакции опор;

$\bar{\Phi}_{\text {c }}$ - сила инерции Кориолиса;

$\bar{\Phi}_{\mathrm{e}}$ - сила инерции переносного движения частицы.

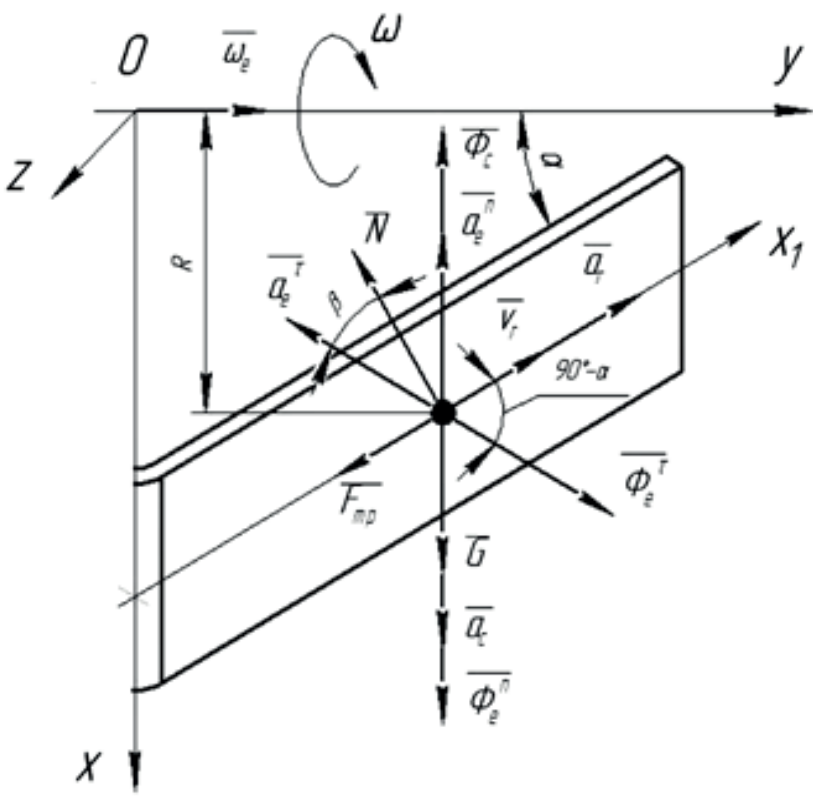

Рис. 2 - Условная схема для определения относительной скорости движения почвы
Силу инерции определим следующим векторным равенством

$$
\bar{\Phi}_{\mathrm{e}}=\bar{\Phi}_{\mathrm{e}}^{\tau}+\bar{\Phi}_{\mathrm{e}}^{\mathrm{n}}
$$

По причине того, что переносное движение частицы почвы осуществляется по окружности, полное ускорение определим следующим образом:

$\overline{\mathrm{a}}_{\mathrm{e}}=\overline{\mathrm{a}}_{\mathrm{e}}^{\mathrm{n}}+\overline{\mathrm{a}}_{\mathrm{e}}^{\tau}$,

где: $\overline{\mathrm{a}}_{\mathrm{e}}^{\mathrm{n}}$ - нормальная составляющая ускорения; ния.

$$
\overline{\mathrm{a}}_{\mathrm{e}}^{\tau} \text { - касательная составляющая ускоре- }
$$

Тогда по (4), (5) равенство (3) примет следующий вид:

$\mathrm{m} \overline{\mathrm{a}}_{\mathrm{r}}=\sum \overline{\mathrm{F}}_{\mathrm{K}}+\bar{\Phi}_{\mathrm{e}}^{\tau}+\bar{\Phi}_{\mathrm{c}}+\bar{\Phi}_{\mathrm{e}}^{\mathrm{n}}$,

где: $\bar{\Phi}_{\mathrm{e}}^{\tau}=\mathrm{m} \cdot \overline{\mathrm{a}}_{\mathrm{e}}^{\tau}-$ касательная сила инерции переносного движения;

$$
\begin{aligned}
& \bar{\Phi}_{\mathrm{c}}=\mathrm{m} \cdot \overline{\mathrm{a}}_{\mathrm{c}} \cdot{ }^{\mathrm{n}} \text { - сила инерции Кориолиса } \\
& \Phi_{\mathrm{e}}^{\mathrm{n}}=\mathrm{m} \cdot \overline{\mathrm{a}}_{\mathrm{e}}^{\mathrm{n}}-\text { нормальная сила инер- }
\end{aligned}
$$

ции.

По рис. 2 и выражению (6) с учетом сил инерции представим все вектора.

Проекции на OX1:

$\mathrm{m} \cdot \mathrm{a}_{\mathrm{r}}=-\mathrm{F}_{\mathrm{Tp}}+\bar{\Phi}_{\mathrm{e}}^{\tau} \cdot \sin \mathrm{a}$.

Сила трения скольжения:

$\mathrm{F}_{\mathrm{Tp}}=\mathrm{f} \cdot \mathrm{N}$,

где: $f$ - коэффрициент трения скольжения вороха по рабочей поверхности поперечного ворошителя;

$\mathrm{N}$ - сила нормального давления.

Составим в проекции на ОХ уравнения равновесия сил:

$\sum \mathrm{F}_{\mathrm{kx}}=0$;

$\Phi_{\mathrm{e}}^{\tau}=-\mathrm{N} \cdot \cos \beta=0$.

Тогда:

$\mathrm{N}=\frac{\Phi_{\mathrm{e}}^{\tau}}{\cos \beta}$

$\mathrm{F}_{\mathrm{Tp}}=\frac{\mathrm{f} \cdot \Phi_{\mathrm{e}}^{\mathrm{\tau}}}{\cos \beta}$.

Преобразуем равенство (7):

$\mathrm{m} \cdot \frac{\mathrm{d} \vartheta_{\mathrm{r}}}{\mathrm{dt}}=-\frac{\mathrm{f} \cdot \Phi_{\mathrm{e}}^{\tau}}{\cos \beta}+\Phi_{\mathrm{e}}^{\tau} \cdot \sin \mathrm{a}=\Phi_{\mathrm{e}}^{\tau} \cdot\left(\sin \mathrm{a}-\frac{\mathrm{f}}{\cos \beta}\right)$,

где

$\mathrm{a}_{\mathrm{r}}=\frac{\mathrm{d} \vartheta_{\mathrm{r}}}{\mathrm{dt}}$.

Тогда

$\mathrm{a}_{\mathrm{e}}^{\tau}=\varepsilon_{\mathrm{e}} \cdot \mathrm{R}$,

где: $\varepsilon_{\text {е }}$ угловое ускорение переносного движения частицы;

$\mathrm{R}$ - радиус переносного движения частицы. Получим:

$$
\mathrm{m} \cdot \frac{\mathrm{d} \vartheta_{\mathrm{r}}}{\mathrm{dt}}=\mathrm{m} \cdot \mathrm{a}_{\mathrm{e}}^{\tau} \cdot\left(\sin \mathrm{a}-\frac{\mathrm{f}}{\cos \beta}\right) ;
$$




$$
\begin{aligned}
& \frac{\mathrm{d} \vartheta_{\mathrm{r}}}{\mathrm{dt}}=\varepsilon_{\mathrm{e}} \cdot \mathrm{R} \cdot\left(\sin \mathrm{a}-\frac{\mathrm{f}}{\cos \beta}\right) ; \\
& \frac{\mathrm{d} \vartheta_{\mathrm{r}}}{\mathrm{dt}}=\frac{\mathrm{d} \omega_{\mathrm{e}}}{\mathrm{dt}} \cdot \mathrm{R} \cdot\left(\sin \mathrm{a}-\frac{\mathrm{f}}{\cos \beta}\right) ; \\
& \int_{0}^{\vartheta_{\mathrm{r}}} \mathrm{d} \vartheta_{\mathrm{r}}=\int_{0}^{\omega_{\mathrm{e}}} \mathrm{R} \cdot\left(\sin \mathrm{a}-\frac{\mathrm{f}}{\cos \beta}\right) \cdot \mathrm{d} \omega_{\mathrm{e}} ; \\
& \vartheta_{\mathrm{r}}=\mathrm{R} \cdot\left(\sin \mathrm{a}-\frac{\mathrm{f}}{\cos \beta}\right) \cdot \omega_{\mathrm{e}}
\end{aligned}
$$

В зависимости от угловой скорости движения определим скорость относительного движения частицы почвы по (18):

$\frac{\mathrm{dx}_{1}}{\mathrm{dt}}=\mathrm{R} \cdot\left(\sin \mathrm{a}-\frac{\mathrm{f}}{\cos \beta}\right) \cdot \omega_{\mathrm{e}}$.

Продиффреренцируем по времени (18) с целью получения уравнения движения частицы почвы, а затем разделим переменные и проинтегрируем:

$\int_{0}^{\mathrm{l}} \mathrm{dx}_{1}=\mathrm{R} \cdot\left(\sin \mathrm{a}-\frac{\mathrm{f}}{\cos \beta}\right) \cdot \omega_{\mathrm{e}} \cdot \int_{0}^{\mathrm{t}} \mathrm{dt}$;

$l=\mathrm{R} \cdot \omega_{\mathrm{e}} \cdot\left(\sin \mathrm{a}-\frac{\mathrm{f}}{\cos \beta}\right) \cdot \mathrm{t}$.

Абсолютную скорость движения частицы почвы можно определить с применением теоремы о сложении скоростей:

$\bar{\vartheta}_{\mathrm{a}}=\bar{\vartheta}_{\mathrm{r}}+\bar{\vartheta}_{\mathrm{e}}$

где:

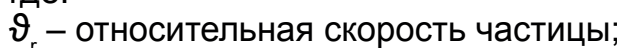

$\vartheta_{\text {e }}^{r}$ - переносная скорость частицы:

$\vartheta_{\mathrm{e}}=\omega_{\mathrm{e}} \cdot \mathrm{R}$.

Определим величину абсолютной скорости по следующему уравнению:

$$
\begin{aligned}
& \bar{\vartheta}_{\mathrm{a}}=\sqrt{\vartheta_{\mathrm{r}}^{2}+\vartheta_{\mathrm{e}}^{2}+2 \cdot \vartheta_{\mathrm{r}} \cdot \vartheta_{\mathrm{e}} \cdot \cos \gamma}, \\
& \text { где } \mathrm{\gamma}-\text { угол между векторами } \bar{\vartheta}_{\mathrm{r}} \text { и } \bar{\vartheta}_{\mathrm{e}} .
\end{aligned}
$$

Преобразуем (24) с учетом (18) и (23)

$$
\begin{aligned}
& \vartheta_{a}=\sqrt{R^{2} \cdot\left(\sin a-\frac{f}{\cos \beta}\right)^{2} \cdot \omega_{e}^{2}+\omega_{e}^{2} \cdot R^{2}+2 \cdot R \cdot\left(\sin a-\frac{f}{\cos \beta}\right) \cdot \omega_{e} \cdot \omega_{e} \cdot R \cdot \cos \gamma}= \\
& \sqrt{R^{2} \cdot \omega_{e}^{2} \cdot\left[\left(\sin a-\frac{f}{\cos \beta}\right)^{2}+1+2 \cdot\left(\sin a-\frac{f}{\cos \beta}\right) \cdot \cos \gamma\right]}= \\
& =R \cdot \omega_{e} \cdot \sqrt{\left(\sin a-\frac{f}{\cos \beta}\right)^{2}+1+2 \cdot\left(\sin a-\frac{f}{\cos \beta}\right) \cdot \cos \gamma} .
\end{aligned}
$$

Выразим радиус поперечного ворошителя:

$$
\mathrm{R}=\frac{\vartheta_{\mathrm{a}}}{\omega_{\mathrm{e}} \cdot \sqrt{\left(\sin \alpha-\frac{\mathrm{f}}{\cos \beta}\right)^{2}+1+2 \cdot\left(\sin \alpha-\frac{\mathrm{f}}{\cos \beta}\right) \cdot \cos \gamma}},
$$

где: $\omega_{\mathrm{e}}=\omega_{5}=20,7 \mathrm{c}^{-1}$;

$\vartheta_{\mathrm{a}}=1,7 \mathrm{~m} / \mathrm{c}$;

$\mathrm{f}$ - коэффрициент трения клубненосного вороха по рабочей поверхности поперечного ворошителя;

$\alpha$-угол наклона витка поперечного ворошителя к плоскости вращения; примем $\alpha=15^{\circ}$ исходя из уменьшения ударного воздействия.

Произведем расчет:

$$
\mathrm{R}=\frac{1,7}{20,7 \cdot \sqrt{\left(0,5-\frac{0,4}{0,8866}\right)^{2}+1+2 \cdot\left(0,5-\frac{0,4}{0,8866}\right) \cdot(-0,5)}}=0,08 \mathrm{M} \text {. }
$$

Тогда $\mathrm{D}=200$ мм.

С увеличением диаметра поперечного ворошителя увеличивается интенсивность воздействия.

$\mathrm{D}=0,20 \mathrm{~m}(\mathrm{R}=\mathrm{r}+\mathrm{h}=0,12 \mathrm{M})$,

$\vartheta_{\mathrm{e}}=\omega_{\mathrm{e}} \cdot \mathrm{R}=20,7 \cdot 0,1=2,8 \frac{\mathrm{M}}{\mathrm{c}}$.

Для определения количества витков поперечного ворошителя применим следующую фрормулу $\mathrm{D}=\frac{\mathrm{z} \cdot \mathrm{b} \cdot \vartheta_{\text {окр }}}{\pi \cdot \vartheta_{\mathrm{M}}}$

где

z - число секций, шт.;

D - диаметр поперечного ворошителя, м;

$\mathrm{D}=200 \mathrm{~mm}$;

$\vartheta_{\text {окр }}$ - окружная скорость поперечного ворошителя, м/c; $\vartheta_{\text {окр }}=1,5 \mathrm{~m} / \mathrm{c}$;

b-ширинапоперечноговорошителя, м; $b=250$ мм;

$\vartheta_{\text {м }}$ - скорость машины, м/с; $\vartheta_{\mathrm{m}}=\vartheta_{\vartheta}=0,9 \mathrm{~m} / \mathrm{c}$.

Из выражения (27) выразим параметр z:

$\mathrm{z}=\frac{\mathrm{D} \cdot \pi \cdot \vartheta_{\mathrm{M}}}{\mathrm{b} \cdot \vartheta_{\text {окр }}}$.

Произведем расчет:

$\mathrm{z}=\frac{0,20 \cdot \pi \cdot 2,1}{0,25 \cdot 1,5}=3,5$.

Принимаем число витков поперечного ворошителя сепарации равным $z=4$.

Как отмечалось, шаг прутков поперечного ворошителя предлагается регулировать с учетом размеров клубней, количества вороха и типа почвы в диапазоне 24-40 мм [7].

Для расчета жесткости поперечного ворошителя применятся формула [8-9]:

$\mathrm{k}_{\mathrm{ye}}=\mathrm{J}_{\mathrm{p}} \cdot \mathrm{G}_{\mathrm{c}}=\frac{\mathrm{G}_{\mathrm{c}} \cdot \mathrm{d}^{4} \cdot}{16 \cdot \mathrm{z} \cdot\left(\mathrm{R}^{2}+(\mathrm{R}-\mathrm{r})^{2}\right)}$,

$\mathrm{G}_{\mathrm{c}}$ - модуль сдвига прутка поперечного ворошителя, $78500 \mathrm{MПа;}$

$\mathrm{r}=\mathrm{d} / 2$ - радиус прутка поперечного ворошителя;

$\mathrm{R}=\mathrm{D} / 2$ - радиус поперечного ворошителя;

$\mathrm{J}_{\mathrm{p}}$ - момент инерции сечения поперечного ворошителя [10]:

$\mathrm{J}_{\mathrm{p}}=\frac{\mathrm{d}^{4} \cdot}{16 \cdot \mathrm{z} \cdot\left(\mathrm{R}^{2}+\mathrm{r}^{2}\right)}$.

По [11] выбираем диаметр прутка пружины $\mathrm{d}=30 \mathrm{~mm}$.

В качестве материала для пружины выбрана сталь конструкционная рессорно-пружинная 60C2A [11].

За счет применения силиконового покрытия пружины уменьшаются повреждения и улучается сохранение клубней картофееля.

Произведем расчет жесткости пружины:

$\mathrm{k}_{\text {yе }}=\frac{78500 \cdot 200^{4}}{16 \cdot 4 \cdot\left(100^{2}+125^{2}\right)}=76,8 \mathrm{H} / \mathrm{Mм}$.

Проведем расчет высоты размещения поперечного ворошителя. Для этого проанализируем 
движение пласта почвы высотой $\mathrm{h}$ относительно точки М поперечного ворошителя с диаметром $\mathrm{d}=2 \cdot \mathrm{r}$ с учетом расположения приводного вала на высоте Н (рис. 5).

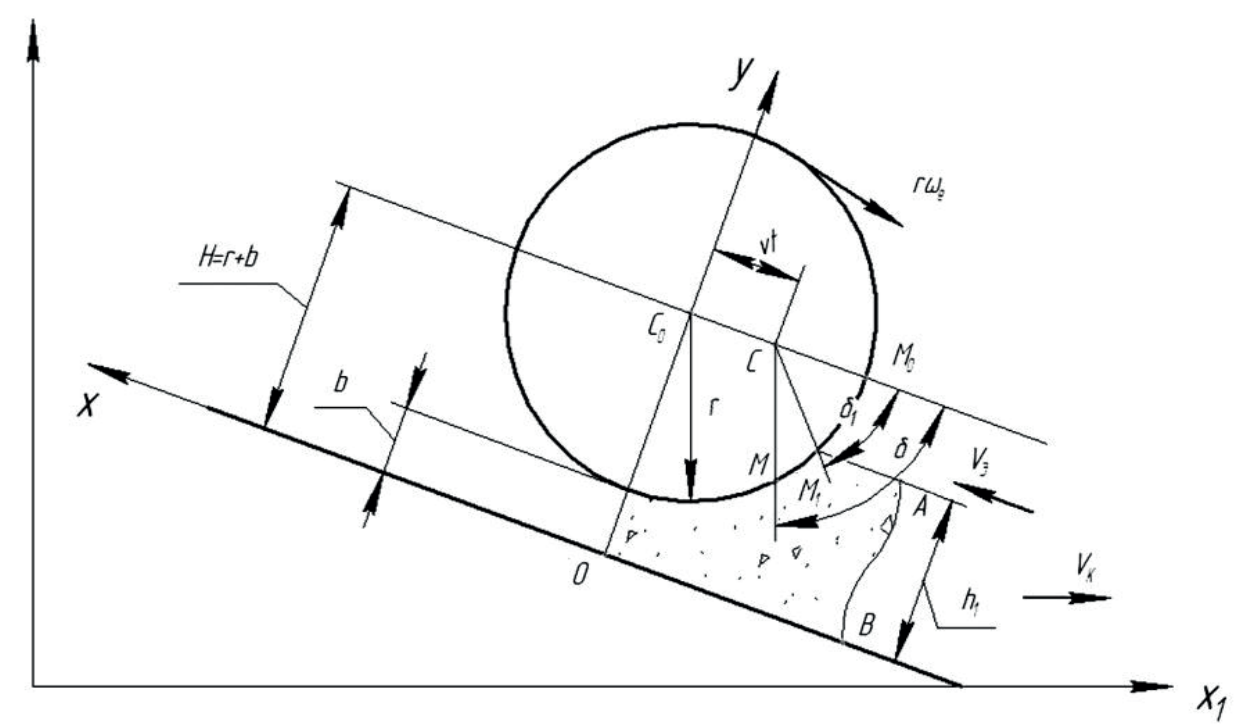

Рис. 3 - Условная схема для определения высоты размещения приводного вала поперечного ворошителя

Изменение координат точки М за некоторый промежуток времени будет иметь следующий вид:

$\left\{\mathrm{X}_{\mathrm{M}}=\mathrm{C}_{0} \mathrm{C}+\mathrm{CM} \cdot \cos \delta=\mathrm{C}_{0} \mathrm{C}+\mathrm{CM} \cdot \cos (\omega \cdot \mathrm{t})\right.$.

$\left\{\mathrm{Y}_{\mathrm{M}}=\mathrm{OC}_{0}-\mathrm{CM} \cdot \sin \delta=\mathrm{OC}_{0}-\mathrm{CM} \cdot \sin (\omega \cdot \mathrm{t})\right.$. Упростим (31):

$$
\left\{\begin{array}{l}
X_{M_{1}}=\vartheta_{\kappa} \cdot t+r \cdot \cos \left(\omega_{e} \cdot t\right) \\
Y_{M_{1}}=r+b-r \cdot \sin \left(\omega_{e} \cdot t\right)
\end{array},\right.
$$

где:

$$
\begin{aligned}
& \mathrm{C}_{0} \mathrm{C}=\vartheta \cdot \mathrm{t} \\
& \mathrm{OC}_{0}=\mathrm{H}=\mathrm{r}+\mathrm{b} .
\end{aligned}
$$

Из системы уравнений (32) определим величину у1 для точки М1 в момент времени $\mathrm{t} 1$ :

$$
\mathrm{y}_{1}=\mathrm{H}-\mathrm{r} \cdot \sin \omega \mathrm{t}_{1}=\left(\mathrm{H}-\mathrm{h}_{1}\right)-\frac{\mathrm{r}}{\frac{\vartheta_{\mathrm{e}}}{\vartheta_{\mathrm{K}}+\vartheta_{\ni}}},
$$

где: $\vartheta_{\text {к }}$ поступательная скорость картофелекопателя; теля;

$\vartheta_{\text {e }}$ - окружная скорость поперечного вороши-

$\vartheta_{\ni}$ - скорость вороха на полотне пруткового элеватора.

Высоту расположения вала $\mathrm{C}_{0}$ можно определить по следующему уравнению:

$\mathrm{H}=\mathrm{h}_{1}+\frac{\mathrm{r}}{\frac{\vartheta_{\mathrm{e}}}{\vartheta_{\mathrm{K}}+\vartheta_{\ni}}}=\mathrm{h}_{1}+\frac{\mathrm{r} \cdot\left(\vartheta_{\mathrm{\kappa}}+\vartheta_{\ni}\right)}{\vartheta_{\mathrm{e}}}$.

Данное уравнение позволяет определить над линией полотна элеватора предельную высоту установки приводного вала поперечного ворошителя, с учетом толщины пласта вороха.

Окончательную высоту, учитывающую попереч- ного ворошителя, можно определить следующим равенством:

$$
\mathrm{H}=\mathrm{h}_{1}+\frac{\mathrm{R}_{1}}{\frac{\vartheta_{\mathrm{e}}}{\vartheta_{\mathrm{K}}+\vartheta_{\ni}}}=\mathrm{h}_{1}+\frac{\mathrm{R}_{1} \cdot\left(\vartheta_{\mathrm{K}}+\vartheta_{\ni}\right)}{\vartheta_{\mathrm{e}}},
$$

где R1=r+h - радиус, учитывающий расположение барабана.

Проведем расчет высоты размещения приводного вала поперечного ворошителя:

$$
\mathrm{H}=0,05+\frac{0,10 \cdot(0,75+0,9)}{1,7}=0,14 \mathrm{M} \text {. }
$$

Принимаем высоту размещения приводного вала предложенного поперечного ворошителя $\mathrm{H}=0,14 \mathrm{M}$.

\section{Заключение}

Предложенная конструктивная схема картофелекопателя содержит поперечный ворошитель, выполненный в виде приводного вала с фланцами. Поперечный ворошитель установлен над каскадным прутковым элеватором с возможностью изменения расстояния между приводным валом ворошителя и прутками элеватора.На приводном валу поперечного ворошителя между фланцами установлены спиральные пружины сжатия, навитые с просветом между витками с правой и левой навивкой, причём спиральные пружины изготовлены из проволоки круглого сечения, а поверхности проволоки выполнены из материала с высоким коэффициентом трения, например, силикона. Использование картофелекопателя с предложенным поперечным ворошителем позволяет уложить картофель за картофелекопателем в валок без раскатывания.

Предложено математическое описание системы, которое позволяет определять оптимальные 
параметры устройства интенсификации картофельной сепарации, обеспечивающего минимальные повреждения урожая и минимальные его потери с учетом размеров клубней, количества вороха и типа почвы.

\section{Список литературы}

1. Патент на изобретение № $2672492 \mathrm{RU}, \mathrm{MПK}$ A01D 17/22 A01D 33/08. Картофелекопатель / Бышов, Н.В. Борычев, С.Н. Костенко, М.Ю. Липин, В.Д. Рузимуродов, А.А - Опубл. 15.11.2018 Бюл.№ 32

2. Борычев, С.Н. Совершенствование технологий и машин для уборки картофеля [Текст] / С.Н. Борычев // Вестник КрасГАУ - 2007.- № 5.- С. 179-185.

3. Пат. РФ №2541384. Картофелеуборочная машина / Бышов Н.В., Тришкин И.Б., Бышов Д.Н., Липин В.Д., Родионов В.В., Липина Т.В. - Опубл. 10.02.201; Бюл. № 34 .

4. Кущев, И.Е. Разработка разветвляющейся технологии уборки картофеля с обоснованием параметров и режимов работы сепарирующих устройств : автореферат дис. ... доктора технических наук: [Текст] / Рязань. гос. с.-х. акад. им. П. А. Костычева. - Рязань, 1999.

5. Рембалович, Г.К. Анализ эксплуатационнотехнологических требований к картофелеуборочным машинам и показателей их работы в условиях Рязанской области [Текст] / Г. К. Рембалович [и др.] // Вестник ФГБОУ ВПО РГАТУ. - 2013. - №1. - C. 64-68.

6. Якутин, Н. Н. Совершенствование технологического процесса и средства интенсификации сепарации картофелеуборочных машин / Н. H. Якутин // Дис. ... канд. техн. наук. - Р., 2014. - 132 с.

7. Бишоп, К. Ф. Механизация производства и хранения картофеля / Пер. с англ. А.С. Каменского / К.Ф. Бишоп, У.Ф. Мондер. - М.: Колос, 1983. $-256 \mathrm{c}$.

8. Рембалович, Г. К. Теоретические исследования процесса интенсификации первичной сепарации в картофелеуборочных машинах динамическим методом / Г. К. Рембалович, М. Ю. Костенко, Д. Е. Каширин, И. А. Успенский, А. А. Голиков // Научный журнал КубГАУ. - 2014. - №102(08).

9. Костенко, М. Ю. Исследование сепарирующей способности прутковых элеваторов/ М. Ю. Костенко, Н. А. Костенко// Сборник научных трудов профессорско-преподавательского состава ФГОУ ВПО РГАТУ имени П.А. Костычева. - Рязань, 2008 - С. 146-148.

10. Беляев, Н. М. Сопротивление материалов: 14-е изд./ Н.М. Беляев. - М.: Наука, 1965. - 846 с.

11. ГОСТ 13764-86. Пружины винтовые цилиндрические сжатия и растяжения из стали круглого сечения. Классифрикация. - М.: Стандартинформ, 2007.

\section{JUSTIFICATION OF THE PARAMETERS OF THE TRANSVERSE TARGITER OF A BAR ELEVATOR OF POTATO HARVESTERS}

Byshow Nikolay V., Dr. of technical Sciences, Professor of Department of exploitation of machinery and tractor Park, Ryazan state agrotechnological University named after P. A. Kostychev, byshov63@mail.ru

Ruzimurodov Abdugafor A., post-graduate student of Department of exploitation of machine and tractor fleet, Ryazan state agrotechnological University named after P. A. Kostychev, gafor1213@mail.ru

Lipin, Vladimir D. PhD. tech. Sciences, associate Professor, Department of technical systems in agriculture Ryazan state agrotechnological University named after P. A. Kostychev, patent@rgatu.ru

The quality of potato harvesting depends on the constructions of the working bodies potato harvesting machines. To reduce labor costs, the modernization of potato harvesting machines is proposed. The task of modernization of the rod Elevator of a potato digger is to increase the destructive effects on the tuberous layer, improve soil separation and reduce losses of potato tubers. To increase the damaging effects on soil lumps and improve soil separation above the cascade bars Elevator a transverse agitator is installed and of potato losses are reduced by limiting the rolling of tubers behind the potato digger with the formation of a potato tuber roll. Researches have found that increasing the efficiency of potato harvesting depends on the operation of separating devices, and the imperfection of structures of their working bodies leads to a decrease in productivity. During the harvest period the weather conditions can be so complex that the equipment cannot perform its functions. A transverse agitator is installed above a cascade Elevator with the possibility of changing the distance between it and the Elevator rods. To determine the transverse diameter of the mixer and the pitch of the rod the relative speed of movement of soil particles is analized and the equations of their motion are presented. A mathematical description of the system is obtained, which allows you to determine the optimal parameters of the transverse agitator device, ensuring minimum damage to the crop and its minimum loss, taking into account the size of the tubers, the amount of heap and the type of soil.

Key words: potato digger, transverse agitator, bar elevator, separation, ploughshare, increased productivity, technological process, improvement.

\section{Literatura}

1. The patent for the invention № 2672492 EN, IPC A01D 17/22 A01D 33/08. Potato Digger / Byshov, N. In. Borichev, S. N. Kostenko, M. Y. Lipin, V. D. Ruzimurodov, A. A. Publ. 15.11 .2018 bul.№ 32

2. Borichev, S. N. Improvement of technologies and machinery for harvesting potatoes [Text] / S. N. Borychev // Vestnik Krasgau - 2007.- No. 5.- S. 179-185.

3. Pat. RF \# 2541384. Potato digger / Byshov N. In. I. B. Trishkin, Byshov D. N., Lipin, V. D., Rodionov V. V., Lipina T. V., Publ. 10.02.201; bull. No. 34.

4. The kuschev, I. E. the Development of the branching technology of harvesting potatoes with the 
justification of parameters and modes of operation separating devices : abstract dis. ... doctor of technical Sciences] [Text] / Ryazan. state agricultural Acad. them. After P. A. Kostychev. - Ryazan, 1999.

5. Rymbalovich, G. K., Analysis of exploitation-technological requirements for potato machines and their performance in the conditions of the Ryazan region] [Text] / G. K. Rymbalovich [and other] // Bulletin of FGBOU VPO RGATU. - 2013. - No. 1. - S. 64-68.

6. Jacutin, N. N. Improving the process and means of intensification of separation of potato machinery / N. N. Jacutin // Dis. kand. tech. Sciences. - R., 2014. - $132 p$

7. Bishop, K. F. Mechanization of production and storage of potatoes / TRANS. from English. A. S. Kamensky / K. F. Bishop, W. F. Maunder. - M.: Kolos, 1983. - 256 p.

8. Rymbalovich, G. K. Theoretical study of process intensification of primary separation in potato machines dynamic method / G. K. Rymbalovich, M. Kostenko, D. E. Kashirin, I. A. Uspensky, A. A. Golikov // Scientific journal of the Kuban state agrarian University. - 2014. - №102(08).

9. Kostenko, M. Y. a study of the separation ability bar elevators/M. Kostenko, N. A. Kostenkol/ Collection of scientific works of the faculty of FGOU VPO RGATU named after P. A. Kostychev. - Ryazan, 2008 - P. 146148.

10. Belyaev, N. M. mechanics of materials: 14th ed./ N. M. Belyaev. - M.: Nauka, 1965. - 846 p.

11. GOST 13764-86. Springs cylindrical helical compression and tension of steel of circular cross-section. Classification.-M.:STANDARTINFORM,2007.

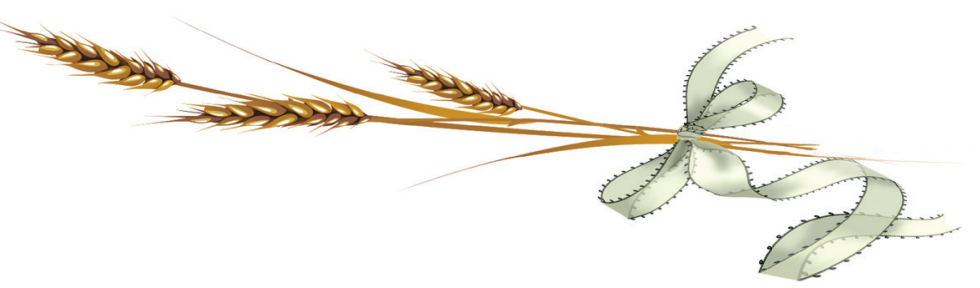

УДК 631.363.258/638.171

DOI 10.36508/RSATU.2020.45.1.015

\section{К ВОПРОСУ ОБОСНОВАНИЯ РАЦИОНАЛЬНЫХ УСЛОВИЙ ОЧИСТКИ ВОСКОВОГО СЫРЬЯ} В ВОДЕ ПРИ ИНТЕНСИВНОМ МЕХАНИЧЕСКОМ ПЕРЕМЕШИВАНИИ

КАШИРИн Дмитрий Евгеньевич, д-р техн. наук, доцент кафедры электроснабжения, kadm76@ mail.ru

УсПЕНСКИЙ Иван Алексеевич, д-р техн. наук, профрессор, зав. кафредрой технической эксплуатации транспорта, ivan.uspensckij@yandex.ru

ПАВЛОВ Виктор Вячеславович, аспирант кафедры электроснабжения, vikp76@mail.ru

ЮХИн Иван Александрович, д-р техн. наук, доцент, зав. каф. автотракторной техники и теплоэнергетики, yuival@rambler.ru

ПЕТУХОВ Алексей Андреевич, аспирант кафедры электроснабжения

Рязанский государственный агротехнологический университет имени П.А. Костычева

Главной технологической операцией при производстве пасечного воска является его термическое выделение из воскового сырья различной сортности с применением сухого или влажного способа вытопки, реализуемого посредством воскотопок всевозможных типов и конструкций. Так как в основу процесса вытопки положен физический принцип стекания расплавленного воска, сырье подвергается обязательному тепловому воздействию с переходом содержащегося в нем свободного воска в жидкое состояние. Сортность воскового сырья непосредственно связана с его восковитостью - массовой долей воска и зависит от количества и состава содержащихся в нем загрязнений. Расплавленный воск взаимодейсвтует с загрязняющими примесями, впитывается в них, переходя в связанное состояние, при этом выход свободно стекаемого воска уменьшается. В основу предлагаемого способа очистки воскового сырья от перги и других водорастворимых примесей положено удаление загрязнений из предварительно измельченных сотов до их горячей переработки путем погружения загрязненного вороха в емкость с водой и интенсивного механического перемешивания в течение непродолжительного времени, в результате чего органические примеси диспергируются или переходят в раствор, и появляется возможность отделить их от очищенных восковых частиц путем процеживания.Целью данного исследования является установление зависимости количества удаленных загрязнений из воскового сырья в результате его очистки в воде при механическом перемешивании лопастной мешалкой с электроприводом от интенсивности процесса перемешивания и его продолжительности. В результате проведенного исследования получена регрессионная модель

() Каширин Д. Е., Успенский И. А., Палов В. В., Юхин И. А., Петухов А. А., 2020 г. 
процесса и проведена оптимизация с установлением максимального значения критерия и соответствущих ему значений исследуемых фракторов.

Ключевые слова: воск, восковое сырье, перга, загрязнения, перемешивание, очистка.

\section{Введение}

Воск - ценный продукт пчеловодства, широко применяемый в целом ряде промышленных отраслей. Эфрфективность его использования напрямую зависит от его качества: чем меньше загрязнений, тем шире спектр промышленного применения воска $[1,2,3,4]$.

Основным загрязнителем воска является перга, а также ульевой сор. Таким образом, примеси в составе воскового сырья являются преимущественно органическими, при этом большинство из них полностью или частично растворимы в воде [5-8]. В условиях практического пчеловодства воск получают путём выплавления его из воскового сырья. В свою очередь сырьё представляет собой старые выбракованные соты, непригодные для дальнейшего использования в пчеловодстве. Как правило, сырьё загрязнено настолько, что содержание воска незначительно и составляет от 10 до $30 \%$ от массы сырья. Поэтому в процессе перетопки загрязненное сырьё впитывает существенную долю воска, при этом часть загрязнений растворяется в нём, что приводит как к ухудшению качества воска, так и к значительным его потерям.

Для решения обозначенной выше проблемы нами предложен способ очистки воскового сырья, защищенный патентом РФ на изобретение [9-14]. Способ предполагает последовательное выполнение следующих операций:

- охлаждение загрязнённого воскового сырья до отрицательных температур с целью придания ему хрупких свойств; массы;

- измельчение до однородной воскоперговой

- интенсивное перемешивание измельчённой массы для растворения (диспергирования) органических загрязнений;

- фильтрование загрязнённой воды для отделения очищенных восковых частиц.

Ключевой операцией предложенного нами способа очистки воскового сырья является интенсивное перемешивание измельчённой массы в воде, так как от качества её выполнения в конечном итоге зависит количество и чистота получаемого воска.

В качестве критерия оптимизации данной операции наиболее целесообразно принять процент растворённых примесей от первоначальной массы загрязненного воскового сырья (в пересчёте на сухое вещество).

Предварительно проведённые опыты показали, что решающее значение на исследуемый процесс оказывают следующие технологические факторы $[15,16]$ :

- интенсивность перемешивания;

- продолжительность перемешивания.

Приведённые соображения предполагают проведение двухфакторного эксперимента.

Материалы и методы исследования

Для выполнения экспериментального исследо- вания из заранее заготовленных выбракованных пчелиных сотов получали восковое сырьё [13, 14, 16]. Сырьё охлаждали до температуры $-5 . . .0^{\circ} \mathrm{C}$ в соответствии с операциями способа (патент РФ №2656968) и измельчали в измельчителе штифтового типа до среднего гранулометрического размера измельченных частиц 3,5 мм, так как данная фракция наиболее пригодна для перемешивания $[12,13,16]$. Далее исследование проводили на специально изготовленной лабораторной установке, представляющей собой пластмассовую цилиндрическую камеру, в верхней части которой закреплён асинхронный электродвигатель, приводящий вал, на противоположном конце которого установлены лопастные мешалки. Конструкция перемешивающего устройства выполнена разборной, что позволяет заменять воду внутри смесительной камеры и обеспечивать необходимую концентрацию перемешиваемого сырья.

Принимая во внимание то обстоятельство, что интенсивность перемешивания I $\left(\mathrm{Bт} / \mathrm{M}^{3}\right)$ - величина, имеющая функциональную зависимость от частоты вращения лопастной мешалки n (Об/мин), было проведено предварительное исследование, на основании результатов которого установлена эмпирическая зависимость (1), представленная в виде графика на рисунке 1

$$
I(n)=\left(3,7 \cdot 10^{-5}\right) \cdot n^{2,637}
$$

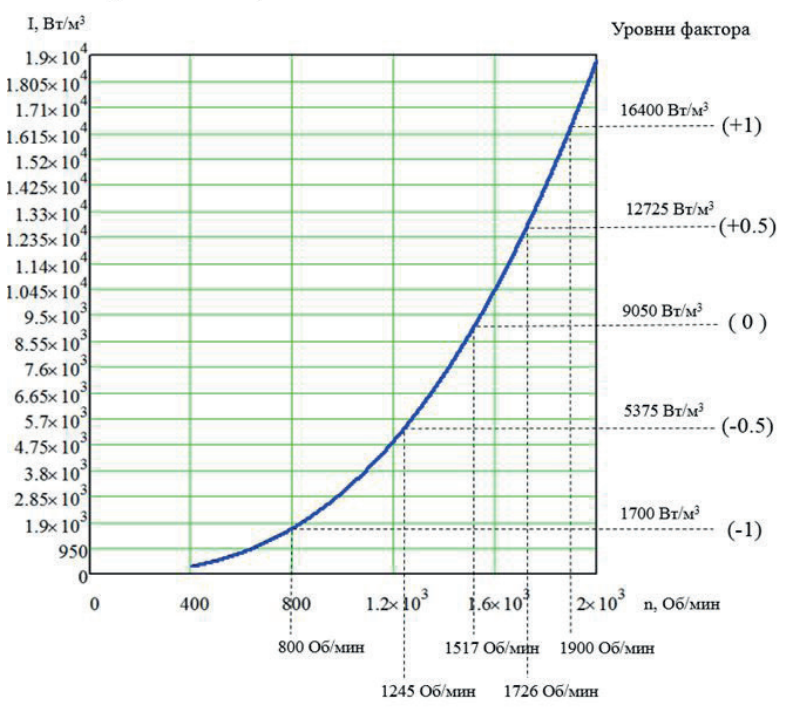

Рис. 1 - Эмпирически установленная зависимость интенсивности перемешивания от величины оборотов мешалки (отмечены пять уровней фактора «интенсивность перемешивания» I, Вт/м³ и соответствующие этим уровням значения оборотов $\mathrm{n}$, Об/мин ${ }^{-1}$ )

Процесс растворения органических загрязнений воскового сырья является весьма сложным с гидродинамической точки зрения, так как процесс зависит от ряда неуправляемых фракторов, проявляющихся с разной степенью интенсивности. В 
частности, траектории движения жидкости вблизи стенок камеры перемешивающего устройства при наличии полных отражательных перегородок [13] носит выраженный стохастический характер.

Принимая во внимание приведённые выше обстоятельства, а также необходимость проведения большого числа повторов, для проведения исследования был выбран ротатабельный пятиуровневый некомпозиционный план второго порядка, предусматривающий проведение 10 опытов (6 в углах шестиугольника, плюс 4 в центре плана). Данный план представлен на рисунке 2. По числу опытов он является более экономичным, чем соответствующий композиционный план второго порядка, требующий выполнения 13 опытов, включая 4 для реализации полного факторного эксперимента, 5 в центре плана и 4 в звездных точках.

Фактор “интенсивность перемешивания" (X1) варьирует на 5 уровнях: $+1 ;+0,5 ; 0 ;-0,5 ;-1$ (в кодированных обозначениях). Соответствующие этим уровням величины оборотов мешалки определялись из эмпирической зависимости (1) и представлены на рис.1. Фактор "время перемешивания" (Х2) варьирует на 3-х уровнях: +0,866; 0; -0,866 (в кодированных обозначениях).

Диапазоны варьирования факторами выбирали, основываясь на результатах предварительно проведённого исследования [16], учитывая технологические особенности потенциального специализированного оборудования.

Факторы и уровни их варьирования приведены в таблице. Эксперимент проводили следующим образом. Из подготовленного описанным выше способом воскопергового вороха формировали

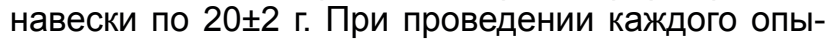
та навеску загружали в лабораторную установку и подвергали перемешиванию в воде с интенсивностью и продолжительностью в соответствии с пла- ном эксперимента. Температура воды составляла 20-22 ${ }^{\circ} \mathrm{C}$.

После завершения процесса перемешивания воду из емкости сливали через заранее подготовленные и взвешенные на весах марки ВЛКТ$500 \mathrm{M}$ сетчатые бюксы, изготовленные из нержавеющей металлической сетки с величиной ячейки 0,5×0,5 мм. Осажденное на сетке восковое сырье ополаскивали холодной водой. Затем бюксы с восковым сырьем подсушивали на воздухе, чтобы вода испарилась из ячеек, а восковое сырье на сетке приобрело рыхлую консистенцию. После этого бюксы с воскосырем взвешивали на весах и вычисляли массу очищенного влажного сырья. Для определения убыли массы в результате очистки первоначальную массу навески и массу очищенного воскосырья необходимо пересчитать на сухое вещество. Для этого определяли влажность очищенного воскового сырья по ГОСТ 31775-2012. Окончательно критерий оптимизации определяется:

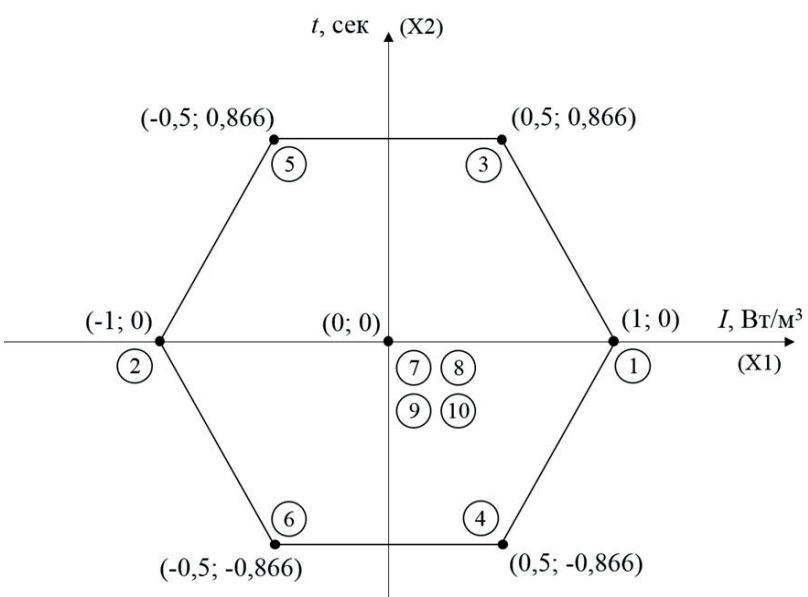

Рис. 2 - Некомпозиционный ротатабельный план второго порядка с кодированным обозначением уровней фракторов

Таблица - Факторы и уровни варьирования

\begin{tabular}{|c|c|c|c|c|c|c|c|c|c|c|}
\hline \multirow{2}{*}{ Фактор } & \multirow{2}{*}{$\begin{array}{c}\text { Обозна- } \\
\text { чение }\end{array}$} & \multirow{2}{*}{ Ед.изм. } & \multicolumn{7}{|c|}{ Уровни варьирования } & \multirow{2}{*}{$\begin{array}{c}\text { Интервал } \\
\text { варьирования }\end{array}$} \\
\hline & & & -1 & $-0,866$ & $-0,5$ & 0 & $+0,5$ & $+0,866$ & +1 & \\
\hline $\begin{array}{l}\text { Интенсив- } \\
\text { ность пере- } \\
\text { мешивания }\end{array}$ & $\mathrm{X} 1$ & $\mathrm{BT} / \mathrm{M}^{3}$ & 1700 & - & 5375 & 9050 & 12725 & - & 16400 & 3675 \\
\hline $\begin{array}{l}\text { Время пере- } \\
\text { мешивания }\end{array}$ & $\mathrm{X} 2$ & сек. & - & 120 & - & 300 & - & 480 & - & 180 \\
\hline
\end{tabular}

$$
\Delta \mathrm{m}_{\%}=\left(1-\frac{\mathrm{m}_{\mathrm{K}} \cdot\left(1-\mathrm{W}_{\mathrm{K}} / 100\right)}{\mathrm{m}_{\mathrm{H}} \cdot\left(1-\mathrm{W}_{\mathrm{H}} / 100\right)}\right) \cdot 100
$$

где $\Delta \mathrm{m}_{\%}$-процент удаленных загрязнений (относительная убыль массы), \%;

$\mathrm{m}_{\mathrm{H}}$ - первоначальная масса навески, г.;

$\mathrm{m}_{\mathrm{r}}$ - масса воскосырья после очистки, г.;

$\mathrm{W}_{\mathrm{H}}^{\mathrm{k}}$ - первоначальная влажность навески воскосырья, \%;

W -влажностьвоскосырьяпослеочистки, \%;

(1-W/100) - пересчет на сухое вещество (ГОСТ 31775-2012).

Повторность проведения каждого опыта равнялась 10.
Результаты исследования

В результате статистической обработки данных проведенного эксперимента были воспроизведены массы опытов по критерию Кохрена, подтверждено условие однородности построчных дисперсий. Построена математическая модель исследуемого процесса (3), графически представленная в виде трехмерной поверхности и линий уровня на рисунке 3 .

$$
\begin{aligned}
& \Delta m_{\%}(I, t)=6,79+0,001 \cdot I+0,038 \cdot t-8,62 \cdot 10^{-7} \cdot l \cdot t- \\
& -1,71 \cdot 10^{-8} \cdot l^{2}-2,2 \cdot 10^{-5} \cdot t^{2}
\end{aligned}
$$

Максимизация ффункции отклика (критерия оптимизации) позволила определить следующие оптимальные значения факторов: 


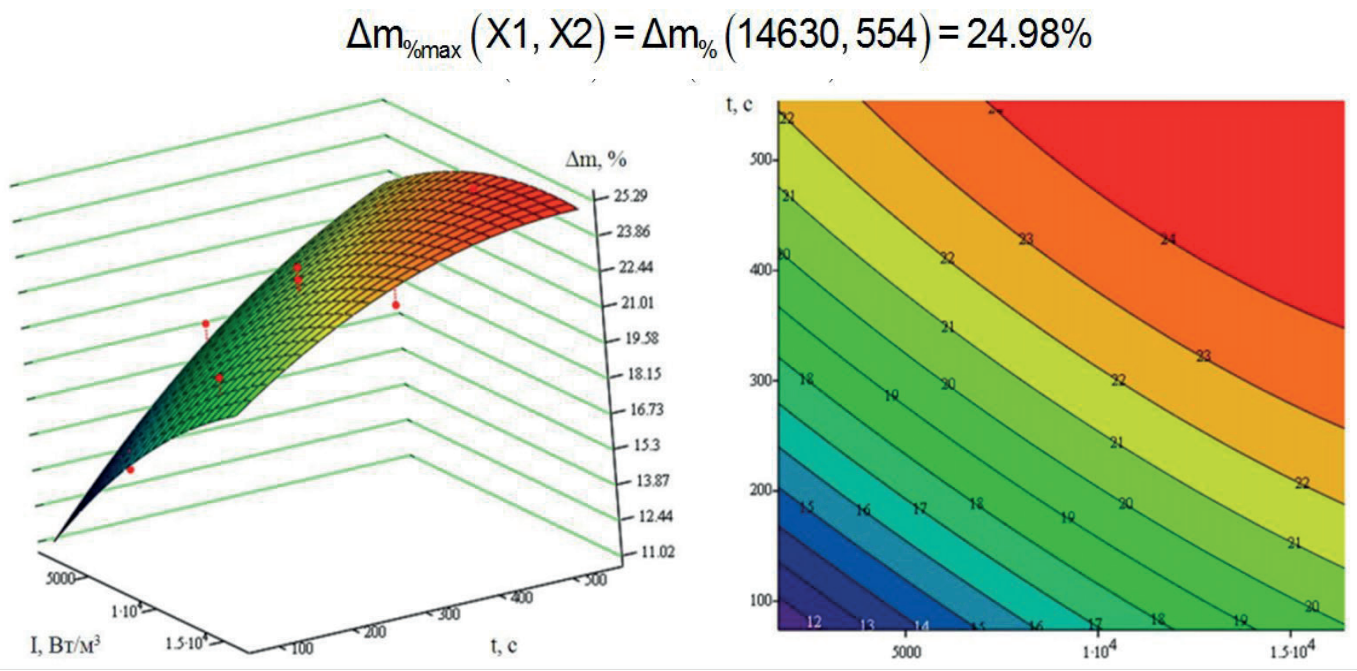

Рис. 3 - Зависимость процента удалённых примесей от исследуемых фракторов: интенсивности перемешивания I, Вт/м³ и времени процесса перемешивания t, c

Анализ установленной зависимости позволяет утверждать, что все исследуемые фракторы значимо влияют на исследуемый процесс. Критерий оптимизации достигает максимума внутри факторного пространства. Рост критерия оптимизации в значительной мере стабилизируется уже при интенсивности порядка 104 Вт/м3 и времени, равном 9-10 минутам. Дальнейшее увеличение значений факторов не привело к заметному росту критерия оптимизации, максимум которого стабилизируется на значении 23-25\% по мере приближения к верхним границам исследуемого факторного пространства. Наиболее существенное влияние на критерий оптимизации оказывает время протекания процесса перемешивания.

\section{Заключение}

В результате проведенного исследования можно сделать следующие выводы.

1. Целесообразно осуществлять предварительную влажную очистку воскового сырья от органических загрязнений до выполнения горячей переработки и вытопки воска.

2. Предлагаемая технология предварительной очистки заключается в измельчении воскового сырья до образования воскового вороха - смеси частиц сотов и органических примесей, последующем его перемешивании в воде с целью диспергирования загрязнений и фильтровании водяной смеси для отделения очищенных восковых частиц. 3. Критерий оптимизации - процент убыли массы сырья в результате очистки достигает максимума внутри факторного пространства. Рост критерия оптимизации в значительной мере стабилизируется на уровне $23-25 \%$ при величине интенсивности перемешивания порядка 104 Вт/м3 и величине времени равном 9-10 минутам. Наиболее существенное влияние на критерий оптимизации оказывает время протекания процесса перемешивания.

\section{Список литературы}

1.Каширин Д.Е. Вакуумная сушка перги / Д.Е. Каширин // Пчеловодство. - 2006. - № 4. - С. 50.

2.Каширин Д.Е. Конвективная сушка перги / Д.Е.
Каширин // Пчеловодство. - 2009.- № 8 - С. 46-47.

3.Каширин Д.Е. Способ и устройство для извлечения перги / Д.Е. Каширин // Аграрный научный журнал. - 2010. - № 5. - С. 34-36.

4.Пат. № 2275800 РФ. Установка для извлечения перги из перговых сотов / Д.Е. Каширин. - Заявл. 28.12.2004; опубл. 10.05.2006, бюл. № 13. - 6с.

5.Каширин Д.Е. Исследование рабочего процесса измельчителя перговых сотов / Д.Е. Каширин // Вестник Федерального государственного образовательного учреждения высшего профессионального образования Московский государственный агроинженерный университет им. В.П. Горячкина. - 2010. - № 1. - С. 24-27.

6.Бышов Д.Н. Исследование рабочего процесса измельчителя перговых сотов / Д.Н. Бышов, Д.Е. Каширин, Н.В. Ермаченков, В.В. Павлов // Вестник Красноярского государственного аграрного университета. - 2015. - № 8. - С. 155-159.

7.Каширин Д.Е. Исследование массы и геометрических параметров перги и перговых сотов / Д.Е. Каширин // Вестник Красноярского государственного аграрного университета. - 2010. - № 5. - C. $152-154$.

8.Бышов Н.В. Обоснование рациональных параметров измельчителя перговых сотов / Н.В. Бышов, Д.Е. Каширин // Вестник Красноярского государственного университета. - 2012. №6. - С. 134-138.

9.Пат. № 2326531 РФ. Способ извлечения перги из сотов / Д.Е. Каширин, А.В. Ларин, М.Е. Троицкая. - Заявл. 19.12.2006; опубл. 20.06.2008, бюл. № 17. $-4 \mathrm{c}$.

10.Бышов Н.В. Обоснование параметров измельчителя перговых сотов / Н.В. Бышов, Д.Е. Каширин // Механизация и электрификация сельского хозяйства. - 2012. - № 1. - С. 29-30.

11.Бышов Д.Н. К вопросу вакуумной инфракрасной сушки перги / Д.Н. Бышов, Д.Е. Каширин, С.Н. Гобелев, С.С. Морозов, А.В. Протасов // Вестник Рязанского государственного агротехнологического университета им. П.А. Костычева. - 2016. - T. 29. - № 1. - C. 56-59. 
12.Бышов Д.Н. Исследование гигроскопических свойств загрязнителей воскового сырья / Д.Н. Бышов, Д.Е. Каширин, В.В. Павлов // Электронный научно-методический журнал Омского ГАУ. - 2016. - № S2. - C. 35.

13.Бышов Д.Н. Исследование гранулометрического состава загрязненного воскового сырья / Д.Н. Бышов, Д.Е. Каширин, С.Н. В.В. Павлов // В сборнике: Энергоэффективные и ресурсосберегающие технологии и системы сборник научных трудов международной научно-практической конференции, посвященной памяти доктора технических наук, профрессора Ф. Х. Бурумкулова. Институт механики и энергетики; Ответственный за выпуск: Столяров А.В. - 2016. - С. 463-465.

14.Пат. № 2297763 РФ. Способ извлечения перги из сотов / Д.Е. Каширин. - Заявл. 05.12.2005; опубл. 27.04.2007, бюл. № 12. - 4с.

15.Харитонова М.Н. Качество перги, стабили- зированной разными способами, в процессе ее хранения / М.Н. Харитонова, Д.Е. Каширин // В сборнике: Инновационные технологии в пчеловодстве Материалы научно-практической конференции. Министерство сельского хозяйства Российской Федерации; Федеральное государственное образовательное учреждение дополнительного профессионального образования специалистов "Академия пчеловодства". - 2006. - С. 195-197.

16.Бышов Д.Н. Результаты многофакторного экспериментального исследования дисперсионных свойств перги / Д.Н. Бышов, Д.Е. Каширин, В.В. Павлов // Вестник Красноярского государственного аграрного университета. - 2017. - №2 (125). - С. 115-121.

17.Каширин Д.Е. Способ и устройство для извлечения перги / Д.Е. Каширин // Аграрный научный журнал. - 2010. - № 5. - С. 34-36.

\title{
TO THE QUESTION OF JUSTIFICATION OF RATIONAL CONDITIONS OF WAX RAW MATERIAL PURIFICATION IN WATER WITH INTENSIVE MECHANICAL MIXING
}

\author{
Kashirin Dmitriy Ye., Dr. tech. Sci., associate Professor, kadm76@mail.ru \\ Uspenskiy Ivan A., Dr. tech. Sci., Professor, ivan.uspensckij@yandex.ru \\ Pavlov Viktor V., graduate student, vikp76@mail.ru \\ Yukhin Ivan A., Dr. tech. Sci., associate Professor, yuival@rambler.ru \\ Petukhov Aleksei A., graduate student \\ Ryazan State Agrotechnological University Named after P.A. Kostychev
}

The main technological operation in the production of apiary wax is its thermal separation from wax raw materials of various grades using a dry or wet refining method, realized through wax reflows of various types and designs. Since the basis of the flooding process is the physical principle of runoff of molten wax, the raw material is subjected to mandatory heat exposure with the transition of the free wax contained in it into a liquid state. The grade of the wax raw material is directly related to its waxiness - the mass fraction of wax and depends on the amount and composition of the impurities contained in it. The molten wax interacts with contaminants, is absorbed into them, passing into a bound state, while the yield of freely draining wax decreases. The basis of the proposed method for cleaning wax raw materials from bee bread and other water-soluble impurities is the removal of contaminants from pre-ground honeycombs before hot processing by immersing the contaminated heap in a container with water and intensive mechanical stirring for a short time, as a result of which organic impurities are dispersed or transferred to solution, and it becomes possible to separate them from the purified wax particles by filtering. The aim of this study is to establish the dependence of the number of removed contaminants from wax raw materials as a result of their purification in water with mechanical stirring with a paddle mixer with an electric drive on the intensity of the mixing process and its duration. As a result of the study, a regression model of the process was obtained and optimization was carried out with the establishment of the maximum value of the criterion and the corresponding values of the studied factors.

Key words: wax, wax raw materials, bee bread, pollution, mixing, cleaning.

\section{Literatura}

1.Kashirin D.E. Vakuumnaya sushka pergi / D.E. Kashirin // Pchelovodstvo. - 2006. - № 4. - S. 50.

2.Kashirin D.E. Konvektivnaya sushka pergi / D.E. Kashirin // Pchelovodstvo. - 2009.- № 8 - S. 46-47.

3. Kashirin D.E. Sposob i ustrojstvo dlya izvlecheniya pergi / D.E. Kashirin // Agrarnyj nauchnyj zhurnal. 2010. - № 5. - S. 34-36.

4.Pat. № 2275800 RF. Ustanovka dlya izvlecheniya pergi iz pergovyh sotov / D.E. Kashirin. - Zayavl. 28.12.2004; opubl. 10.05.2006, byul. № 13. - 6s.

5.Kashirin D.E. Issledovanie rabochego processa izmel'chitelya pergovyh sotov / D.E. Kashirin // Vestnik Federal'nogo gosudarstvennogo obrazovatel'nogo uchrezhdeniya vysshego professional'nogo obrazovaniya Moskovskij gosudarstvennyj agroinzhenernyj universitet im. V.P. Goryachkina. - 2010. - № 1. - S. $24-27$.

6.Byshov D.N. Issledovanie rabochego processa izmel'chitelya pergovyh sotov /D.N. Byshov, D.E. Kashirin, N.V. Ermachenkov, V.V. Pavlov // Vestnik Krasnoyarskogo gosudarstvennogo agrarnogo universiteta. - 2015. - № 8. - S. 155-159.

7.Kashirin D.E. Issledovanie massy i geometricheskih parametrov pergi i pergovyh sotov / D.E. Kashirin // Vestnik Krasnoyarskogo gosudarstvennogo agrarnogo universiteta. - 2010. - № 5. - S. 152-154.

8.Byshov N.V. Obosnovanie racional'nyh parametrov izmel'chitelya pergovyh sotov / N.V. Byshov, D.E. Kashirin // Vestnik Krasnoyarskogo gosudarstvennogo universiteta. - 2012. №6. - S. 134-138. 
9.Pat. № 2326531 RF. Sposob izvlecheniya pergi iz sotov / D.E. Kashirin, A.V. Larin, M.E. Troickaya. Zayavl. 19.12.2006; opubl. 20.06.2008, byul. № 17. - 4s.

10.Byshov N.V. Obosnovanie parametrov izmel'chitelya pergovyh sotov / N.V. Byshov, D.E. Kashirin // Mekhanizaciya i elektrifikaciya sel'skogo hozyajstva. - 2012. - № 1. - S. 29-30.

11. Byshov D.N. K voprosu vakuumnoj infrakrasnoj sushki pergi / D.N. Byshov, D.E. Kashirin, S.N. Gobelev, S.S. Morozov, A.V. Protasov // Vestnik Ryazanskogo gosudarstvennogo agrotekhnologicheskogo universiteta im. P.A. Kostycheva. - 2016. - T. 29. - № 1. - S. 56-59.

12.Byshov D.N. Issledovanie gigroskopicheskih svojstv zagryaznitelej voskovogo syr'ya / D.N. Byshov, D.E. Kashirin, V.V. Pavlov // Elektronnyj nauchno-metodicheskij zhurnal Omskogo GAU. - 2016. - № S2. - S. 35. 13.Byshov D.N. Issledovanie granulometricheskogo sostava zagryaznennogo voskovogo syr'ya / D.N. Byshov, D.E. Kashirin, S.N. V.V. Pavlov // V sbornike: Energoeffektivnye i resursosberegayushchie tekhnologii i sistemy cbornik nauchnyh trudov mezhdunarodnoj nauchno-prakticheskoj konferencii, posvyashchennoj pamyati doktora tekhnicheskih nauk, professora F. H. Burumkulova. Institut mekhaniki i energetiki; Otvetstvennyj za vypusk: Stolyarov A.V. - 2016. - S. 463-465.

14.Pat. № 2297763 RF. Sposob izvlecheniya pergi iz sotov / D.E. Kashirin. - Zayavl. 05.12.2005; opubl. 27.04.2007, byul. № 12. - 4s.

15. Haritonova M.N. Kachestvo pergi, stabilizirovannoj raznymi sposobami, v processe ee hraneniya / M.N. Haritonova, D.E. Kashirin // V sbornike: Innovacionnye tekhnologii v pchelovodstve Materialy nauchnoprakticheskoj konferencii. Ministerstvo sel'skogo hozyajstva Rossijskoj Federacii; Federal'noe gosudarstvennoe obrazovatel'noe uchrezhdenie dopolnitel'nogo professional'nogo obrazovaniya specialistov "Akademiya pchelovodstva". - 2006. - S. 195-197.

16.Byshov D.N. Rezul'taty mnogofaktornogo eksperimental'nogo issledovaniya dispersionnyh svojstv pergi I D.N. Byshov, D.E. Kashirin, V.V. Pavlov // Vestnik Krasnoyarskogo gosudarstvennogo agrarnogo universiteta. - 2017. - №2 (125). - S. 115-121.

17. Kashirin D.E. Sposob i ustrojstvo dlya izvlecheniya pergi / D.E. Kashirin // Agrarnyj nauchnyj zhurnal. 2010. - № 5. - S. 34-36.

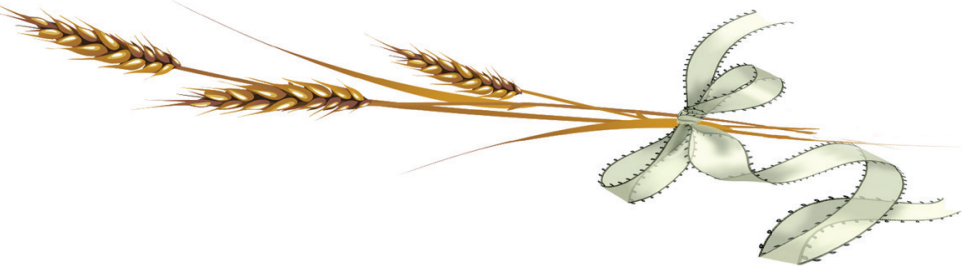

\section{ИССЛЕДОВАНИЯ ТОЛЩИНЫ ВАЛКА ХЛЕБНОЙ МАССЫ В ЗАВИСИМОСТИ ОТ УГЛА ПОЛОЖЕНИЯ ПОДБИРАЮЩЕЙ ПОВЕРХНОСТИ ПРУЖИННОГО ПАЛЬЦА}

ЛОВчИкОВ Александр Петрович, д-р техн. наук, профрессор ФГБОУ ВО Южно-Уральский государственный аграрный университет, профессор кафедры «Тракторы, сельскохозяйственные машины и земледелие», alovcikov@mail.ru

КОНСТАНТИНОВ Михаил Маерович, Заслуженный работник высшей школы РФ, д-р техн. наук, профрессор ФГБОУ ВО Оренбургский государственный аграрный университет, профрессор кафедры «Механизация технологических процессов в АПК», miconsta@yandex.ru

КОРОВИН Юрий Иванович, канд. техн. наук, ФГБОУ ВО «Московский государственный универcuтет пищевых производств», профессор кафредры "Общий и таможенный менеджмент», уига. korovin.61@mail.ru

ОГНЕВ Игорь Игоревич, канд. техн. наук, ФГАОУ ВО Уральский федеральный университет имени первого Президента России Б.Н. Ельцина, доцент кафредры «Подъемно-транспортные машины u poбomы», ognev.i.i@yandex.ru

ОГНЕВ Игорь Геннадьевич, канд. техн. наук, доцент ФГАОУ ВО Уральский федеральный универcuтет имени первого Президента России Б.Н. Ельцина, доцент кафредры «Подъемно-транспортные машины и роботы»,i.g.ognev@urfu.ru

ГЛУШКОВ Иван Николаевич, канд. техн. наук, ФГБОУ ВО Оренбургский государственный аграрный университет, доцент кафредры «Землеустройство и кадастры», i-n-g2012@yandex.ru

Валовой сбор зерна определяет решение проблемы обеспечения страны продовольственным, фруражным и семенным зерном, а также формирует сырьевую базу для развития многих отраслей промышленности. Вопрос снижения потерь зерна при раздельной уборке урожая зерновых культур при использовании транспортерного подборщика является важной научной и прикладной задачей. В настоящей работе проведены лабораторные исследования по определению толщины валка хлебной массы в зависимости от угла положения подбирающей поверхности пружинного пальца. В данной

() Ловчиков А. П., Константинов М. М., Коровин Ю. И., Огнев И. И., Огнев И. Г., Глушков И. Н., 2020 г. 
статье была рассмотрена методика проведения экспериментальных исследований на лабораторной специальной установке. Пружинные стандартные пальцы серийного подборщика рассматривались в эксперименте в качестве контрольных. Полученные в лабораторных условиях результаты исследований по замеру толщины валка хлебной массы в зависимости от угла положения подбирающей поверхности пружинного пальца позволили установить, что использование пружинного пальца с кольцевым витком на его подбирающей поверхности позволяет уплотнить хлебную массу по сравнению со стандартными пружинными пальцами, применяемыми на серийных подборщиках, на 20,0-30,0\% за счет того, что применение пружинных пальцев даёт более «мягкий» режим работы при подборе хлебной массы. Анализ проведенных экспериментальных исследований, рассматриваемых в данной статье, показывает, что использование подбирающего пальца, выполненного с кольцевым витком на его подбирающей поверхности, дает более быстрое уплотнение хлебной массы валка, в результате чего достигается снижение вероятности образования потерь зерна в процессе подбора хлебной массы валка.

Ключевые слова: раздельная уборка зерновых культур, зерноуборочный комбайн, транспортерный подборщик, подбирающий палец, валок хлебной массы.

\section{Введение}

Пшеница - важнейшая культура для Российской Федерации, поскольку обеспечивает население страны фрактически половиной калорийности ежедневного рациона.

Поэтому необходимо не только применять высокие технологии возделывания и уборки сельскохозяйственных культур, высокоурожайные сорта и гибриды зерновых культур, высокоэффективные технологии использования, повышения уровня надежности и работоспособности зерноуборочных машин, но и решить проблему повышения качества уборки, так как ежегодно потери зерна в Российской Федерации, достигают 15 миллионов тонн [1].

В связи с этим необходимо решать проблему повышения качества уборки зерновых культур за счет внедрения в производство высокоэффективных технических средств, таких как транспортерные подборщики зерноуборочных комбайнов.

Использование транспортерного подборщика, оснащенного серийными пружинными пальцами, не дает требуемого результата при выполнении технологического процесса подбора валка хлебной массы, так как подобные подборщики являются основным источником потерь зерна [2].

В связи с этим транспортерный подборщик должен быть оснащен подбирающими пальцами, обеспечивающими повышение качества уборки и уменьшения потерь зерна.

\section{Материалы и методы исследований}

Для проверки теоретических предпосылок необходимо провести лабораторные исследования замера толщины валка хлебной массы в зависимости от угла положения подбирающей поверхности пружинного пальца.

В экспериментальных исследованиях применялась лабораторная установка, имитирующая процесс подбора валка хлебной массы транспортером подборщика (рис. 1, а). Установка включала цепь (4) с прикрепленными на ней подбирающими пальцами (2), ведомую (3) и ведущую (5) звездочки привода цепи (3), приводимые в движение с помощью асинхронного двигателя (6), доски (1), имитирующей поверхность поля, и стерни (7), на которую укладывалась хлебная масса валка. Подбирающие пальцы имеют геометрию подбирающей поверхности с наличием кольцевого витка 1 , дуги 2 и стандартную (серийный палец) 3 (рис.1,б).
Методика предусматривала серию предварительных опытов с целью определения эксплуатационных режимов лабораторной установки и проверки работоспособности пружинных пальцев с измененной геометрией (рис. 1,б). Для этого к подвижной доске 1, имитирующей поверхность поля, прикреплялась деревянная линейка 3 , которая крепилась строго перпендикулярно к поверхности доски (рис.2).

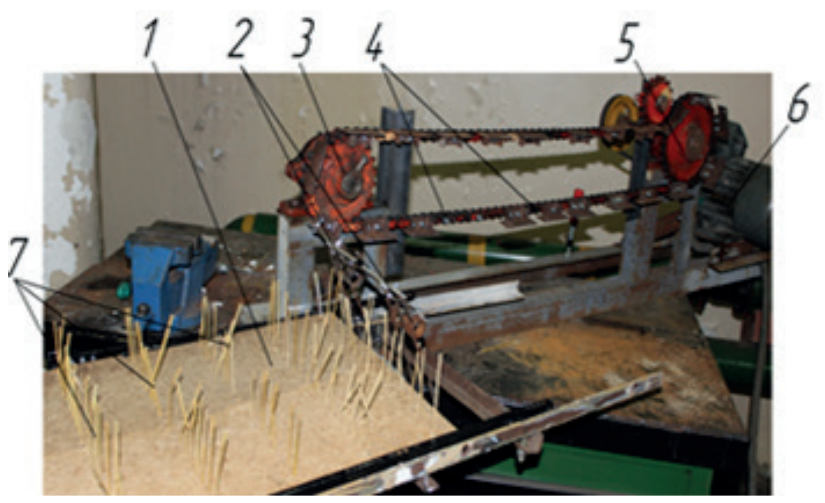

1 - подвижная доска, имитирующая поверхность поля; 2 - пружинные пальцы; 3 - ведомая звездочка привода цепи; 4 - цепь; 5 - ведущая звездочка привода цепи; 6 - асинхронный двигатель; 7 - стерня

Рис. 1 - Общий вид лабораторной установки
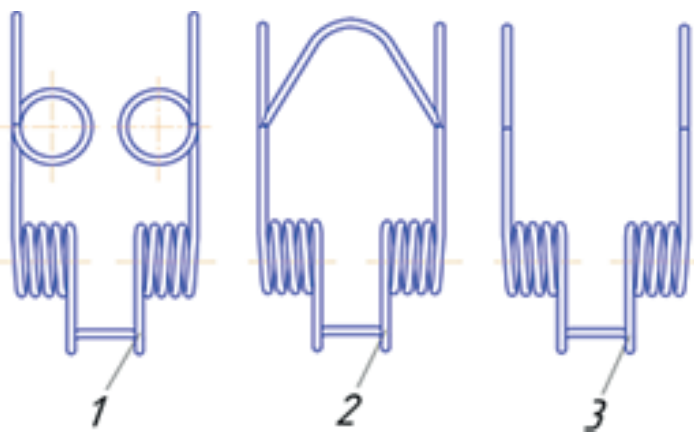

1 - пружинный палец с кольцевым витком на подбирающей поверхности

(Пат. № 158040 RU MПК A 01 D 89/00);

2 - пружинный палец с дугой на подбирающей поверхности; 3 - стандартный пружинный палец Рис. 2 - Сменные пружинные пальцы с различной геометрией подбирающей поверхности 


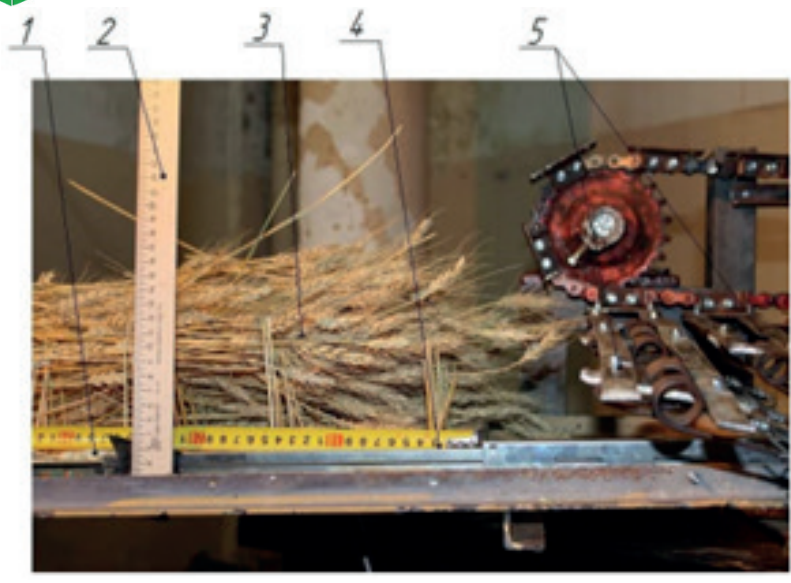

1 - подвижная доска, имитирующая поверхность поля; 2 - измерительная линейка;

3 - хлебная масса валка; 4 - рулетка; 5 - пружинные пальцы

Рис. 2 - Схема замера толщины валка хлебной массы

Далее на подвижную доску 1, имитирующую поверхность поля в лабораторной установке, укладывался валок хлебной массы 3. Пружинные пальцы 5 устанавливались на 0 градусов. Градация угла подъема бралась в пределах от 0 до 45 градусов. С помощью измерительной линейки 3 замерялась верхняя кромка положения валка от поверхности подвижной доски 1 и нижняя кромка положения валка хлебной массы над поверхностью подвижной доски 1 в зависимости от угла

Таблица 1 -Толщина валка хлебной массы в зависимости от угла положения пружинного стандартного пальца

\begin{tabular}{|c|c|c|c|c|c|c|c|c|}
\hline \multirow{2}{*}{$\begin{array}{c}\text { Угол положения } \\
\text { подбирающей по- } \\
\text { верхности пальца, } \\
\text { град }\end{array}$} & \multicolumn{9}{|c|}{ Толщина хлебной массы валка, м } \\
\cline { 2 - 9 } & 1 & 2 & 3 & 4 & 5 & \multicolumn{3}{c|}{$\begin{array}{c}\text { статистические } \\
\text { характеристики }\end{array}$} \\
\hline 0 & 0,150 & 0,148 & 0,152 & 0,144 & 0,149 & 0,149 & 0,003 & 1,79 \\
\hline 10 & 0,146 & 0,145 & 0,141 & 0,142 & 0,143 & 0,143 & 0,002 & 1,29 \\
\hline 15 & 0,140 & 0,140 & 0,133 & 0,141 & 0,136 & 0,138 & 0,003 & 2,20 \\
\hline 20 & 0,138 & 0,139 & 0,140 & 0,136 & 0,136 & 0,138 & 0,002 & 1,16 \\
\hline 25 & 0,135 & 0,138 & 0,132 & 0,133 & 0,133 & 0,134 & 0,002 & 1,59 \\
\hline 30 & 0,132 & 0,130 & 0,132 & 0,129 & 0,130 & 0,131 & 0,001 & 0,92 \\
\hline 35 & 0,130 & 0,128 & 0,130 & 0,126 & 0,128 & 0,128 & 0,001 & 1,17 \\
\hline 40 & 0,132 & 0,128 & 0,132 & 0,128 & 0,129 & 0,130 & 0,002 & 1,41 \\
\hline 45 & 0,133 & 0,129 & 0,132 & 0,129 & 0,129 & 0,130 & 0,002 & 1,34 \\
\hline
\end{tabular}

Таблица 2 - Толщина валка хлебной массы в зависимости от угла положения пружинного пальца с дугой на подбирающей поверхности

\begin{tabular}{|c|c|c|c|c|c|c|c|c|}
\hline \multirow{2}{*}{$\begin{array}{c}\text { Угол положения } \\
\text { подбирающей по- } \\
\begin{array}{c}\text { верхности пальца, } \\
\text { град }\end{array}\end{array}$} & \multicolumn{9}{|c|}{ Толщина хлебной массы валка, м } \\
\cline { 2 - 9 } & 1 & 2 & 3 & 4 & 5 & \multicolumn{3}{c|}{$\begin{array}{c}\text { статистические } \\
\text { характеристики }\end{array}$} \\
\hline 0 & 0,140 & 0,140 & 0,138 & 0,138 & 0,138 & 0,139 & 0,001 & 0,71 \\
\hline 10 & 0,140 & 0,142 & 0,140 & 0,138 & 0,138 & 0,140 & 0,001 & 1,07 \\
\hline
\end{tabular}

положения пружинных пальцев 5. На основании полученных замеров верхней и нижней кромок, определялась толщина валка хлебной массы.

Угол положения пружинных пальцев измерялся с помощью транспортира. Повторность опытов была пятикратной. Замеры толщины валка проводились для стандартного пружинного пальца (контроль) и экспериментальных пальцев.

Результаты исследований и их обсуждение

В соответствии с программой экспериментальных исследований были проведены опыты замера уплотнения валка хлебной массы в зависимости от угла положения пружинного пальца. Оценка выаром вариантам: в первом варианте на лабораторную установкукрепились стандартные пружинные пальцы, во втором - эксперименпальцы с дугой на подбирающей поверх ности, в третьем - экспериментальные пальцы с кольцевым витком на подбирающей поверхности. Пружинные стандартные пальцы рассматривались в эксперименте как контрольные. Предварительными опытами с фотосъемкой процесса уплотнения хлебной массы валка в зависимости от угла положения пружинного пальца в вертикальной плоскости во время взаимодействия с ной массой валка было установлено, что экспериментальные пальцыс дугой и кольцевым витком на подбирающей поверхности работают удоврежиты работы транспортёра лабораторной установки в трех вариантах были одинаковыми, (масса одного погонного метра валка хлебной массы $\mathrm{m}=4$ кг/пог. м). Результаты экс-

периментов приведены в таблицах 1, 2, 3 
Продолжение таблицы 2

\begin{tabular}{|c|l|l|l|l|l|l|l|l|}
\hline 15 & 0,142 & 0,145 & 0,137 & 0,137 & 0,137 & 0,140 & 0,003 & 2,38 \\
\hline 20 & 0,140 & 0,143 & 0,139 & 0,138 & 0,137 & 0,139 & 0,002 & 1,48 \\
\hline 25 & 0,139 & 0,142 & 0,137 & 0,136 & 0,136 & 0,138 & 0,002 & 1,65 \\
\hline 30 & 0,139 & 0,143 & 0,140 & 0,141 & 0,141 & 0,140 & 0,002 & 1,40 \\
\hline 35 & 0,138 & 0,141 & 0,141 & 0,139 & 0,137 & 0,139 & 0,002 & 1,15 \\
\hline 40 & 0,135 & 0,137 & 0,139 & 0,139 & 0,139 & 0,138 & 0,002 & 1,16 \\
\hline 45 & 0,132 & 0,139 & 0,139 & 0,139 & 0,140 & 0,138 & 0,003 & 2,12 \\
\hline
\end{tabular}

Таблица 3 - Толщина валка хлебной массы в зависимости от угла положения пружинного пальца с кольцевым витком на подбирающей поверхности

\begin{tabular}{|c|c|c|c|c|c|c|c|c|}
\hline \multirow{2}{*}{$\begin{array}{c}\text { Угол положения } \\
\text { подбирающей по- } \\
\text { верхности пальца, }\end{array}$} & \multicolumn{9}{|c|}{ Толщина хлебной массы валка, м } \\
\cline { 2 - 9 } град & \multicolumn{3}{|c|}{ повторность опыта } & \multicolumn{4}{c|}{$\begin{array}{c}\text { статистические } \\
\text { характеристики }\end{array}$} \\
\cline { 2 - 9 } & 1 & 2 & 3 & 4 & 5 & $\bar{x}$ & $\sigma$ & $v, \%$ \\
\hline 0 & 0,096 & 0,094 & 0,095 & 0,095 & 0,094 & 0,095 & 0,001 & 0,79 \\
\hline 10 & 0,095 & 0,096 & 0,095 & 0,091 & 0,093 & 0,094 & 0,002 & 1,09 \\
\hline 15 & 0,099 & 0,100 & 0,100 & 0,099 & 0,098 & 0,099 & 0,001 & 0,75 \\
\hline 20 & 0,100 & 0,100 & 0,100 & 0,098 & 0,100 & 0,100 & 0,001 & 0,80 \\
\hline 25 & 0,100 & 0,110 & 0,110 & 0,099 & 0,100 & 0,104 & 0,004 & 4,05 \\
\hline 30 & 0,094 & 0,097 & 0,095 & 0,099 & 0,096 & 0,096 & 0,002 & 1,79 \\
\hline 35 & 0,093 & 0,097 & 0,095 & 0,094 & 0,092 & 0,094 & 0,002 & 1,83 \\
\hline 40 & 0,093 & 0,095 & 0,094 & 0,092 & 0,093 & 0,093 & 0,001 & 1,09 \\
\hline 45 & 0,094 & 0,094 & 0,094 & 0,093 & 0,092 & 0,093 & 0,001 & 0,86 \\
\hline
\end{tabular}

На основании данных таблиц, представленных выше, была построена гистограмма, показывающая изменение толщины валка хлебной массы в зависимости от угла положения подбирающей поверхности пружинного пальца (рис. 3).

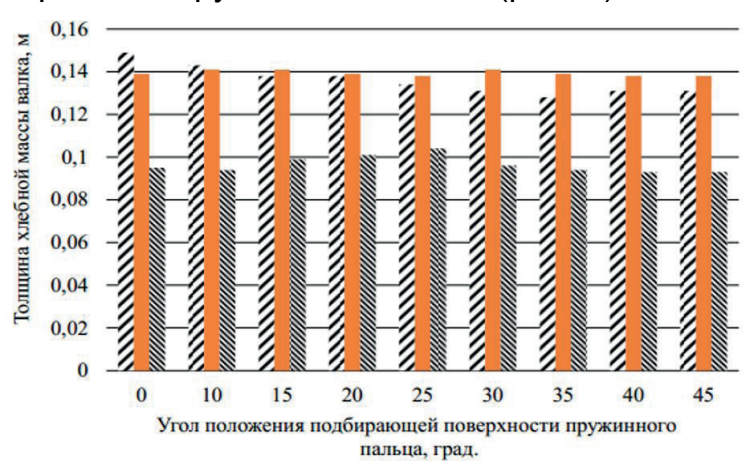

ССтандартный пружинный палец

шПружинный палец с дугой на подбирающей поверхности

Пружинный палец с кольцевым витком на подбирающей поверхности

Рис. 3 - Гистограмма изменения толщины хлебной массы валка в зависимости от угла положения подбирающей поверхности пружинного пальца

\section{Выводы}

В ходе проведения исследований толщины валка хлебной массы в зависимости от угла положения подбирающей поверхности пружинного пальца было установлено, что наличие кольцевого витка на подбирающей поверхности приводит к интенсификации процесса самоуплотнения хлебной массы во время её подъема со стерни. Так, замеры толщины хлебной массы валка в зависимости от угла положения подбирающей поверхности пружинного пальца относительно горизонтальной плоскости показывают, что наличие кольцевого витка на подбирающей поверхности ускоряет уплотнение хлебной массы в 1,2-1,3 раза в сравнении со стандартными (серийными) пружинными пальцами. Таким образом, использование подбирающего пальца, выполненного с кольцевым витком на подбирающей поверхности, позволяет быстрее уплотнять хлебную массу валка и посредством этого уменьшить вероятность образования потерь зерна при подборе хлебной массы валка, а также выпадения короткостебельных колосьев из валка хлебной массы за счет более «мягкого» режима работы данного пальца.

\section{Список литературы}

1. Федорова, О.А. Эффрективные технические решения повышения качества уборки зерновых культур: автореф. дис. ... докт. техн. наук : 05.20.01 / Федорова О.А. - Рязань, 2018. - 40 с.

2. Огнев, И.И. Снижение потерь зерна за подборщиком при комбайновой уборке урожая совершенствованием подбирающей поверхности пружинных пальцев: автореф. дис. ... канд. техн. наук: 05.20.01 / Огнев И.И. - Оренбург, 2017. -21 с.

3.Жалнин, Э. В. Технологии уборки зерновых комбайновыми агрегатами/ Жалнин Э. В., Савченко А.Н. - М. : Россельхозиздат, 1985. - 207 с.

4. Коренев, Г.В.Прогрессивные способы уборки и борьба с потерями урожая /Коренев Г. В., Тарасенко А. П. - 2-е изд., перераб. и доп. - М. : Колос, 1983. - 175 с.

5. Косилов, Н. И. Состояние и тенденции совершенствования зерноуборочных машин : учеб. пособие / Косилов Н. И. - Челябинск, 1983. - 103 с.

6. Кленин, Н. И. Сельскохозяйственные и ме- 
лиоративные машины. Элементы теории рабочих процессов. Расчет регулировочных параметров и режимов работы : учебник/Кленин Н. И., СакунВ. А. - 2-е изд., перераб. и доп. - М.: Колос, 1980. - 671 с

7. Сельскохозяйственные и мелиоративные машины : учеб. пособие / Г.Е. Листопад [и др.]. -
М. : Колос, 1976. - 751 c.

8.Патент № 158040 RU MПК A 01 D 89/00. Пружинный подбирающий палец для транспортерного подборщика зерноуборочного комбайна / А.П. Ловчиков, И.И. Огнев. - № 2015118490/13; заявл. 18.05.2015; опубл. 20.12.2015, Бюл. № 35.

\section{EVALUATION OF THICKNESS MEASUREMENT OF A BREAD MASS ROLL DEPENDING ON THE ANGLE OF THE SEARCHING SURFACE OF A SPRING FINGER}

Lovchikov Alexandr P., doctor of technical Sciences, Professor, South Ural state agrarian University, Professor of the Department "Tractors, agricultural machines and agriculture", alovcikov@mail.ru

Konstantinov Mikhail M, Honored worker of higher school of Russia, doctor of engineering. Professor of Orenburg state agrarian University, Professor of the Department "Mechanization of technological processes in agriculture", miconsta@yandex.ru

Korovin Yuri I, Cand. tech. Ph. D., Moscow state University of food production, Professor of the Department of General and customs management, yura.korovin.61@mail.ru

Ognev Igor I. candidate of technical Sciences, Ural Federal University named after the first President of Russia B. N. Yeltsin, Professor of the Department "Lifting and transport machines and robots", ognev.i.i@ yandex.ru

Ognev Igor G. candidate of technical Sciences, Professor, Ural Federal University named after the first President of Russia B. N. Yeltsin, Professor of the Department " Lifting and transport machines and robots",i.g.ognev@urfu.ru

GlushkovIvan N., candidate oftechnical Sciences, Orenburg state agrarian University,i-n-g2012@yandex.ru

The issue of reducing grain losses during separate harvesting of grain crops using a conveyor baler is an important scientific and applied task. In this work, the obtained results of laboratory studies to determine the thickness of the roll of bread mass depending on the angle of position of the picking surface of the spring pin were investigated. In this article the method of experimental research on a laboratory installation was examined. The obtained results of laboratory studies measuring the thickness of the roll of the bread mass from the angle of position of the picking surface of the spring finger revealed that the use of a spring finger with an annular coil on the picking surface allows to compact the bread mass compared to standard spring fingers by 20.0 - 30.0\%, and due to a more "soft" mode of operation of the spring fingers. Thus, the correctness of the basic theoretical provisions of the work was confirmed and it became possible to make a comparative assessment of the work of standard picking fingers and fingers with a modified geometry of the picking surface.

Key words: separate harvesting of grain crops, combine harvester, conveyor picker, picking finger, roll of bread mass.

\section{Literatura}

1. Fedorova, O.A. Effektivnye tekhnicheskie resheniya povysheniya kachestva uborki zernovyh kul'tur: avtoref. dis. ... dokt. tekhn. nauk : 05.20.01 / Fedorova O.A. - Ryazan', 2018. - 40 s.

2. Ognev, I.I. Snizhenie poter' zerna za podborshchikom pri kombajnovoj uborke urozhaya sovershenstvovaniem podbirayushchej poverhnosti pruzhinnyh pal'cev: avtoref. dis. ... kand. tekhn. nauk: 05.20.01 / Ognev I.I. - Orenburg, 2017. -21 s.

3.ZHalnin, E. V. Tekhnologii uborki zernovyh kombajnovymi agregatami/ ZHalnin E. V., Savchenko A.N. M. : Rossel'hozizdat, 1985. - 207 s.

4. Korenev, G. V. Progressivnye sposoby uborki i bor'ba s poteryami urozhaya /Korenev G. V., Tarasenko A. P. - 2-e izd., pererab. i dop. - M. : Kolos, 1983. - 175 s.

5. Kosilov, N. I. Sostoyanie i tendencii sovershenstvovaniya zernouborochnyh mashin : ucheb. posobie / Kosilov N. I. - CHelyabinsk, 1983. - 103 s.

6. Klenin, N. I. Sel'skohozyajstvennye i meliorativnye mashiny. Elementy teorii rabochih processov. Raschet regulirovochnyh parametrov i rezhimov raboty : uchebnik / Klenin N. I., Sakun V. A. - 2-e izd., pererab. i dop. - M.: Kolos, 1980. - $671 \mathrm{~s}$

7. Sel'skohozyajstvennye i meliorativnye mashiny : ucheb. posobie / G.E. Listopad [i dr.]. - M. : Kolos, 1976. $-751 \mathrm{~s}$.

8.Patent № 158040 RU MPK A 01 D 89/00. Pruzhinnyj podbirayushchij palec dlya transporternogo podborshchika zernouborochnogo kombajna / A.P. Lovchikov, I.I. Ognev. - № 2015118490/13; zayavl. 18.05.2015; opubl. 20.12.2015, Byul. № 35.

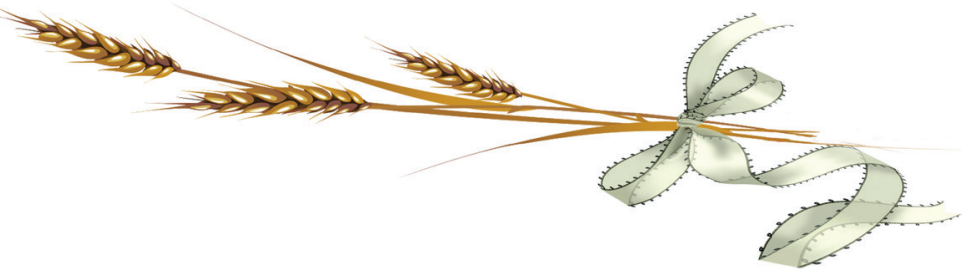


Удк 638.171.2

DOI 10.36508/RSATU.2020.45.1.017

TЕОРЕТИЧЕСКОЕ ОБОСНОВАНИЕ РАБОТЫ ВОСКОПРЕССА «ЛИСИЦА» ПРИ ОТЖИМЕ ВОСКА ИЗ МЕРВЫ

МАКСИМОВ Николай Михайлович, канд. тех. наук, доцент кафедры автомобилей, тракторов и сельскохозяйственных наук, max@vgsa.ru

НИКИФОРОВ Николай Витальевич, ст. преподаватель кафееры автомобилей, тракторов и сельскохозяйственных машин, nikforof@vgsa.ru

Великолукская государственная сельскохозяйственная академия

Пчеловодство является важной отраслью сельского хозяйства. Одним из важнейших продуктов пчеловодства является воск, получаемый из пчелиных сотов. При перетопке тёмных пчелиных сот, в которых выводился пчелиный расплод, неизбежно остаются отходы - мерва. Для извлечения воска из мервы применяются прессы различных конструкций. В силу простоты конструкции наибольшую популярность среди пчеловодов приобрёл воскопресс «Лисица». Целью настоящего исследования является теоретический анализ сил, действующих в воскопрессе «Лисица» при прессовании мервы, а также практическое определение количества получаемого воска из мервы в зависимости от развиваемого давления прессования. В статье дано теоретическое обоснование процесса отжима мервы с использованием воскопресса "Лисица». Представлена кинематическая схема воскопресса, обозначены силы, действующие в нём при отжиме мервы. Приведено уравнение моментов сил и даны фрормулы для расчёта давления прессования мервы. Установлено, что развиваемое давление прессования напрямую зависит от эффрективной длины верхнего рычага воскопресса и приложенного к нему усилия. В тексте работы приведены материалы и методика исследований с описанием экспериментальной установки и контрольно-измерительных приборов. Получены результаты исследования влияния давления прессования мервы на количество получаемого воска. Установлено, что при увеличении давления прессования в 2 раза, с 86 до 172 кПа, выход воска при прессовании мервы увеличивается в 1,5 раза и составляет 459 г для тёмных сот и 361 г для коричневых. $B$ статье даны выводы и рекомендации по улучшению работы воскопресса, а также приведён анализ полученных аналитических зависимостей.

Ключевые слова: восковое сырьё, мерва, перетопка воска, воскопресс, пчелиные соты

\section{Введение}

Пчеловодство является неотъемлемой частью агропромышленного комплекса Российской Федерации. Разведение и содержание пчёл позволяет увеличивать урожайность сельскохозяйственных культур при их опылении. Одной из главных операций в технологии производства продукции пчеловодства, без которой невозможно дальнейшее увеличение количества пчелосемей, является производство воска из пчелиных сот [1-5]. Большая часть воска идёт на изготовление вощины, которая необходима для правильной отстройки сотов пчёлами на гнездовых и магазинных рамках. В процессе перетопки воскосырья неизбежно остаются не перетапливаемые остатки пчелиных сот - мерва. Мерва ещё содержит некоторое количество воска, содержание которого зависит от возраста пчелиных сот. Для извлечения оставшегося воска требуется прессование мервы. С этой целью используются различные конструкции винтовых прессов, электрические центрифуги и другие устройства. Наибольшее применение в пчеловодстве, в силу простоты конструкции и отсутствия

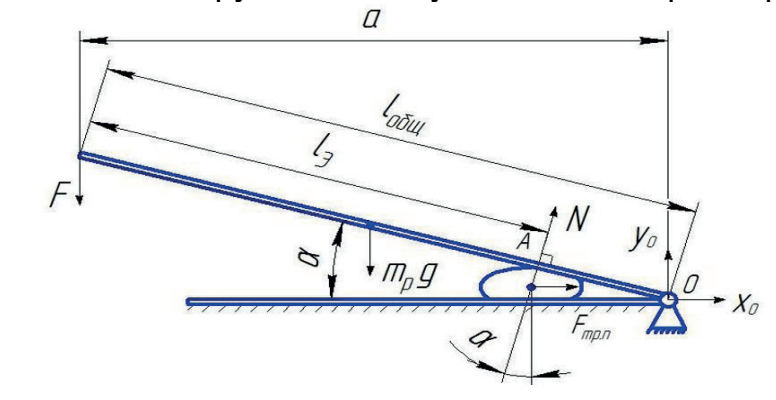

сложных узлов нашёл воскопресс «Лисица». Был сделан теоретический анализ сил, возникающих при прессовании мервы, и проведены практические испытания.

\section{Цель и задачи исследований}

Целью настоящего исследования является теоретический анализ сил, действующих в воскопрессе «Лисица» при прессовании мервы, а также практическое определение количества получаемого воска из мервы в зависимости от развиваемого давления прессования.

\section{Материалы и методика исследований}

Воскопресс «Лисица» с точки зрения теоретической механики представляет собой систему из двух рычагов, подвижно соединённых друг относительно друга [6]. Нижний рычаг (основание пресса) в процессе работы, как правило, неподвижен и служит опорой. Верхний рычаг подвижен и может откидываться для установки и извлечения отжимаемой мервы, расположенной в проницаемой оболочке. Рассмотрим схему сил, действующих в воскопрессе, и обозначим основные конструктивные размеры (рис. 1).

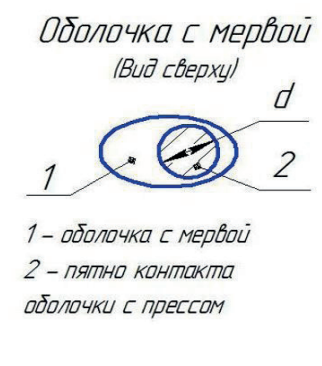

Рис. 1 - Схема сил действующих при отжиме мервы воскопрессом «Лисица

(๖) Максимов Н. М., Никифорово Н. В., 2020 г. 
Основные конструктивные размеры воскопресса можно выразить формулами. Общая габаритная длина воскопресса:

$a=l_{\text {обй }} \cdot \cos \alpha$,

где $l_{\text {обш }}$ общая длина прижимного рычага, м; $\alpha$ - угол наклона прижимной панели, град.

Расстояние от шарнирного соединения до центра оболочки с мервой:

$O A=l_{\text {ö̆i }}-l_{\ni}$,

где $l_{3}$ - эффрективная длина рычага, м.

Сумма моментов сил для воскопресса запишется уравнением:

$\Sigma M_{0}=F \cdot a-N \cdot\left(l_{\text {об̆ }}-l_{\ni}\right)+m_{p} g \frac{a}{2}=0$, $\mathrm{H}$;

где $F$ - сила действия руки человека на рычаг,

$N$ - сила, действующая на оболочку с мервой в пятне контакта, $\mathrm{H}$;

$m_{p}-$ масса рычага, кг;

$g$ - ускорение свободного падения, м/с².

Отсюда получаем силу, действующую на оболочку с мервой в пятне контакта:

$N=\frac{F \cdot a+m_{p} \cdot g \cdot \frac{a}{2}}{l_{\text {обй }}-l_{\ni}} ;$ или $N=\frac{\left(2 F+m_{p} g\right) a}{2\left(l_{\text {ö̈u }}-l_{\ni}\right)}$.

Давление прессования мервы запишется выражением:

$P=\frac{N \cdot \cos \alpha}{S}$,

где $S$ - площадь пятна контакта, $\mathbf{M}^{2}$.

Принимая допущение, что пятно контакта имеет круглую форму и её размер практически не зависит от силы $F$, площадь пятна контакта может быть определена по формуле:

$$
S=\frac{\pi \cdot d^{2}}{4} \text {. }
$$

где d-максимальныйдиаметрпятна контакта, м.

Анализ полученных аналитических уравнений позволяет сделать вывод, что количество воска, которое можно получить при отжиме мервы зависит в первую очередь от создаваемого в воскопрессе давления $\mathrm{P}(5)$. Давление прессования $\mathrm{P}$ в свою очередь зависит от силы N, действующей на оболочку с мервой. Развиваемая сила $\mathrm{N}$ также зависит от расположения оболочки с мервой относительно нижнего рычага и усилия $F$, прикладываемого к верхнему рычагу воскопресса. При смещении оболочки с мервой влево, (расстояние ОА будет увеличиваться) эфффективная длина рычага $l_{\text {э }}$ будет уменьшаться, а значит следом будет уменьшаться сила $\mathrm{N}$ и давление прессования $\mathrm{P}$. Таким образом при одинаковом усилии $F$, прикладываемом на ручку воскопресса, для увеличения выхода воска эффрективнее смещать оболочку с мервой вправо, к оси вращения О воскопресса (рис. 1). С увеличением общей длины прижимного рычага $l_{\text {обм }}$ давление прессование также будет расти.
В летний период 2019 года на частной пасеке были проведены испытания воскопресса лисица, оборудованного усиленным рычагом (рис. 2). Для опытов были выбраны 6 партий гнездовых рамок Дадана (435×300 мм) по 6 рамок в каждой. В опыте использовались разновозрастные соты, не содержащие перги, условно разделённые на 2 группы. Первая группа: соты после 6 вышедших поколений расплода (коричневые соты), вторая группа: соты после 12 вышедших поколений расплода (тёмные соты). Каждая партия взвешивалась и помещалась в рамочную воскотопку для вытопки воска. Источником пара служил твердотопливный парогенератор [7]. По окончании перетопки каждой партии рамок в рамочной воскотопке оставалась мерва, которая собиралась в проницаемую полипропиленовую оболочку и производилось прессование воскопрессом «Лисица» (рис. 2). Воск из мервы собирался в отдельную ёмкость (на рисунке отсутствует) и далее производилось его взвешивание. Отжатая прессом мерва убиралась на отдельную площадку

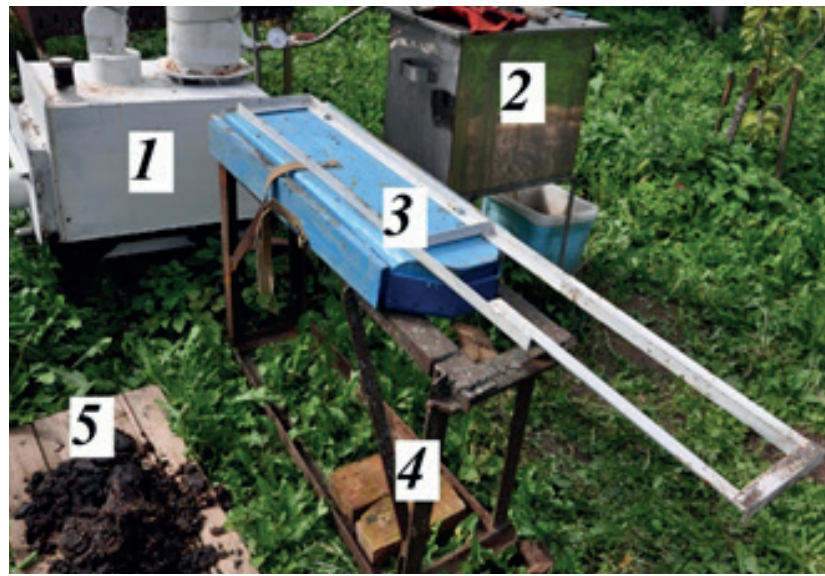

1 - парогенератор; 2 - рамочная воскотопка;

3 - воскопресс «Лисица»; 4 - опорная рама воскопресса; 5 - отжатая мерва

Рис. 2 - Общий вид оборудования для переработки воскосырья

Начальная температура мервы при загрузке в воскопресс «Лисица» составляла $97-100{ }^{\circ} \mathrm{C}$. Температура нагрева мервы контролировалась бесконтактным инфрракрасным термометром модели «CEM DT - 8833». Прессование мервы осуществлялось за 3 подхода, по 1 минуте на каждый подход. Время прессования мервы за один подход - не более минуты. Между подходами мерва в оболочке вынималась из воскопресса и повторно помещалась в рамочную воскотопку для нагрева паром. Усилие $F$ (рис. 1), прикладываемое на рукоятку воскопресса, измерялось при помощи цифрового безмена UNIT UBS-2110EL, имеющего максимальную нагрузку 50 кг и погрешность измерений \pm 50 г. Взвешивание мервы до и после прессования осуществлялось при помощи электронного безмена Штрих-M E-Scale 45, с максимальной нагрузкой 45 кг и погрешностью \pm 10 г. Взвешивание отжатого прессом воска осуществлялось при 
помощи электронных кухонных весов Polaris PKS 0531ADL Crystal, с максимальной нагрузкой 5 кг и точностью измерений \pm 2 г. По полученным данным строились графические зависимости (рис. 3).

\section{Результаты и их анализ}

Решение полученных уравнений (1-5) показало, что воскопресс «Лисица» при имеющихся начальных конструктивных параметрах $\left(\mathrm{I}_{\text {общ }}=1,5 \mathrm{M}, \mathrm{I}_{\ni}=1,3 \mathrm{M}, \alpha=20^{\circ}\right)$ и при начальном усилии, находящемся в пределах $F=200 \div 400$ H способен создать усилие прессования в точке контакта пресса с оболочкой мервы в пределах $\mathrm{N}=1410-2820 \mathrm{H}$. Давление прессования мервы при этом лежит в пределах $\mathrm{P}=86-172$ кПа. При заданных пределах давлений были проведены испытания воскопресса с трёхкратной повторностью и получены средние значения выхода воска из мервы. Выхода воска из мервы пчелиных сот разного возраста на воскопрессе «Лисица» можно представить в виде диаграммы (рис. 3).

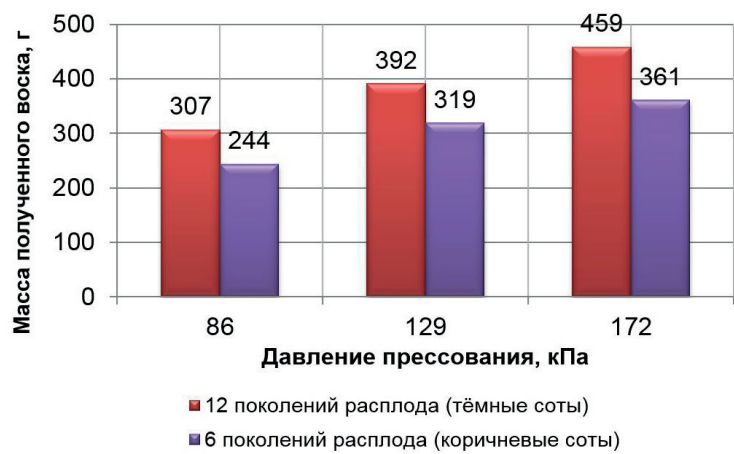

Рис. 3 - Зависимость массы полученного воска от давления прессования мервы

Группа из 6 рамок с тёмными сотами содержала 2049 г мервы после перетопки рамок в воскотопке, а группа из 6 рамок с коричневыми сотами 1285 г мервы. Из мервы тёмных сот при давлении 172 кПа удалось получить 459 г воска. Из мервы коричневых сот при давлении 172 кПа удалось получить 361 г воска. При этом масса полученного воска в рамочной воскотопке до прессования мервы для тёмных и коричневых сот составила 371г и 706г соответственно. Масса мервы после прессования для тёмных и коричневых сот составила 1590г и 924г соответственно.

Создаваемое давление прессования мервы зависит от эффективной длины рычага воскопресса и прилагаемого к нему усилия. С ростом давления прессования, количество выжимаемого воска из мервы увеличивается. Установлено, что при увеличении давления прессования в 2 раза, с 86 до 172 кПа, выход воска в обоих случаях увеличивается в 1,5 раза. Стоит учесть, что увеличение давления прессования ограничивается прочностными свойствами материалов воскопресса «Лисица». Большее количество выжимаемого воска из тём- ных сот (12 поколений расплода), по сравнению с коричневыми сотами (6 поколений расплода) объясняется наличием большего количества не перетапливаемых остатков в тёмных сотах (коконов после выхода расплода), в которых задерживается воск. Светлые и светло-коричневые соты (1-2 поколений расплода) не содержащие перги, перетапливаются практически без остатка.

\section{Заключение}

Проведённые исследования показали необходимость использования воскопресса для отжима мервы при перетопке тёмных пчелиных сот. На первоначальном этапе для отжима мервы, пчеловодам-практикам подойдёт воскопресс «Лисица», в силу простоты его конструкции. Эфффективность работы воскопресса «Лисица» может быть увеличена за счёт рационального выбора его конструктивных параметров, к числу которых следует отнести длину прижимного рычага.

Дальнейшим этапом совершенствования конструкции воскопресса может стать внедрение подогревателя. Это позволит обеспечить подогрев мервы при прессовании, без её извлечения из воскопресса, а значит, трудозатраты при перетопке воска будут уменьшены.

\section{Список литературы}

1. Некрашевич, В. Ф. Механизация пчеловодства / В. Ф. Некрашевич, Ю. Н. Кирьянов. - 2-е изд., перераб. и расшир. - Рязань, 2011. - 266 с.

2. Исследование процесса получения воска из воскового сырья различного качества / Н.В. Бышов, Д.Н. Бышов, Д.Е. Каширин [и др.] // Вестник КрасГАУ. - 2015. - №6. - С. 145-149.

3. К вопросу прессования воскового сырья В процессе вытопки. / В. Д. Хмыров, Т. В. Гребенникова, П. Ю. Хатунцев, А. Н. Тимофееев // Вестник Рязанского ГАТУ. - 2015. - № 4 (28). - С. 102-106.

4. Максимов, Н. М. Предпосылки к разработке технологии переработки воскосырья на пасеках с использованием парогенератора / Н. М. Максимов // Материалы 69-ой Международной научно-практической конференции (25 апреля 2018 года) в 2-х ч. Ч. II. - Рязань: Издательство РГАТУ, 2018. - С. 237-241.

5. Максимов, Н. М. Многофакторное исследованиевыработкипаравпарогенератореприперетопке воска/Н. М. Максимов, О. М. Афанасьева// Инновации в сельском хозяйстве. - 2019. - №31. -С. 84-91.

6. Яблонский, А. А. Курс теоретической механики. Т.1: Статика. Кинематика.: учеб. / А. А. Яблонский, В. М. Никифорова. - М.: Высшая школа, 1966. -438 с.

7. Пат. 188608 Российская Федерация, МПК7 А 01 K 59/06 (2006.01) F 24 C 1/00 (2006.01). Парогенератор для вытопки воска / Морозов В. В., Максимов Н. М.; заявитель и патентообладатель Великолук.. гос. с.-х. академия. - № 2018106374/18; заявл. 20.02.2018; опубл. 17.04.2019, Бюл. №11. - 2 с.: ил.

\section{THEORETICAL JUSTIFICATION OF THE WORK OF THE WAX PRESS "FOX" WHEN PRESSING WAX FROM WASTE}

Maximov Nikolai M., Cand. technical Sciences, associate Professor of the Department of automobiles, tractors and agricultural Sciences, max@vgsa.ru 
Nikiforov Nikolay V., senior lecturer of the Department of automobiles, tractors and agricultural machinery, nikforof@vgsa.ru

Veliky Luki state agricultural Academy

Beekeeping is an important branch of agriculture. One of the most important products of beekeeping is wax obtained from honeycombs. When re-digging dark honeycombs in which the bee brood is displayed, waste is inevitably left. Presses of various designs are used to extract wax from waste. Due to the simplicity of the design, the most popular among beekeepers was the "Fox" wax press. The purpose of this study is a theoretical analysis of the forces acting in the "Fox" wax press when pressing waste from wax, as well as a practical determination of the amount of wax produced from waste depending on the developed pressing pressure. The article provides a theoretical justification for the process of pressing waste from wax using the "Fox" wax press. The kinematic scheme of the wax press is presented, and the forces acting in it when pressing waste from wax are indicated. The equation of moments of forces is given and formulas for calculating the pressure of pressing waste from wax are given. It is established that the developed pressing pressure directly depends on the effective length of the upper arm of the wax press and the force applied to it. The text of the work contains materials and methods of research with a description of the experimental installation and control and measuring devices. The results of the study of the influence of the pressure of pressing waste from wax on the amount of wax produced are obtained. It was found that with an increase in the pressing pressure of 2 times, from 86 to $172 \mathrm{kPa}$, the output of wax during the pressing of waste increases by 1.5 times and is $459 \mathrm{~g}$ for dark cells and $361 \mathrm{~g}$ for brown ones. The article provides conclusions and recommendations for improving the operation of the wax press, as well as an analysis of the obtained analytical dependencies

Key words: the raw material of wax, waste of wax, wax melting, press for wax, bee honeycombs.

\section{Literatura}

1. Nekrashevich. V. F. Mekhanizatsiya pchelovodstva / V. F. Nekrashevich. Yu. N. Kirianov. - 2-e izd.. pererab. i rasshir. - Ryazan'. 2011. - 266 s.

2. Issledovaniye protsessa polucheniya voska iz voskovogo syria razlichnogo kachestva / N.V. Byshov. D.N. Byshov. D.E. Kashirin [i dr.] // Vestnik KrasGAU. - 2015. - №6. - S. 145-149.

3. K voprosu pressovaniya voskovogo syria v protsesse vytopki. / V. D. Khmyrov. T. V. Grebenni-kova. P. Yu. Khatuntsev. A. N. Timofeyev // Vestnik Ryazanskogo GATU. - 2015. - № 4 (28). - S. 102-106.

4. Maksimov. N. M. Predposylki k razrabotke tekhnologii pererabotki voskosyria na pasekakh s ispolzovaniyem parogeneratora / N. M. Maksimov // Materialy 69-oy Mezhdunarodnoy nauchno-prakticheskoy konferentsii (25 aprelya 2018 goda) v 2-kh ch. Ch. Il. - Ryazan': Izdatelstvo RGATU. 2018. - S. $237-241$.

5. Maksimov. N. M. Mnogofaktornoye issledovaniye vyrabotki para v parogeneratore pri pere-topke voska / N. M. Maksimov. O. M. Afanasyeva // Innovatsii v selskom khozyaystve. - 2019. - №31. -S. 84-91.

6. Yablonskiy. A. A. Kurs teoreticheskoy mekhaniki. T.1: Statika. Kinematika.: ucheb. / A. A. Yab-lonskiy. V. M. Nikiforova. - M.: Vysshaya shkola. 1966. - $438 \mathrm{~s}$.

7. Pat. 188608 Rossiyskaya Federatsiya. MPK7 A 01 K 59/06 (2006.01) F 24 C 1/00 (2006.01). Parogenerator dlya vytopki voska / Morozov V. V.. Maksimov N. M.; zayavitel i patentoobladatel Veli-koluk.. gos. s.-kh. akademiya. - № 2018106374/18; zayavl. 20.02.2018; opubl. 17.04.2019. Byul. №11. - 2 s.: il.

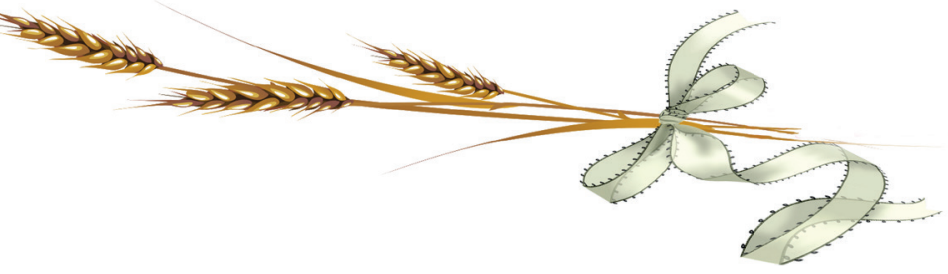

УДК 632.982.2:631.81

DOI 10.36508/RSATU.2020.45.1.018

\section{СПОСОБ АЭРОЗОЛЬНОЙ ОБРАБОТКИ ПРОПАШНЫХ КУЛЬТУР}

TЕТЕРИН Владимир Сергеевич, канд. техн. наук, зав. отделом №2, cm. науч. сотрудник, Labiogiant@mail.ru

ГАПЕЕВА Наталья Николаевна, канд. биол. наук, вед. науч. compудник, gapeevann@mail.ru

ПАНФЕРОВ Николай Сергеевич, канд. техн. наук, зам. директора по инновационным разработкам и развитию экспериментального производства, nikolaj-panfyorov@yandex.ru

Институт технического обеспечения сельского хозяйства - ффилиал Федерального государственного бюджетного научного учреждения «Федеральный научный агроинженерный центр ВИМ»

Органоминеральные удобрения (гуматы) являются мощным средством защиты растений и почвы от экологических загрязнений. Одна из главных и ценных особенностей гуминовых препаратов - совместимость их использования с применением пестицидов. При этом гума- 
ты усиливают действие пестицидов, что позволяет снизить дозы ядохимикатов на 20-40\%. Это способствует улучшению агроэкологической ситуации и дает возможность сэкономить на приобретении дорогостоящих пестицидов. Кроме того, включение гуматов в состав баковых смесей позволяет снизить негативные последствия от применения ядохимикатов. С целью повышения эффрективности обработки растений защитно-стимулирующими препаратами, включающими в свой состав гуматы, был разработан способ аэрозольной обработки пропашных культур. Он заключается в обработке растений защитно-стимулирующими препаратами, поступающими в тоннельные укрытия в виде аэрозоля, создаваемого генератором горячего тумана. В баковую смесь для обработки растений совместно со средствами защиты растений добавляется раствор солей гуминовых кислот. Одновременно с обработкой растений в рядках с помощью системы ультрамалообъемного опрыскивания осуществляется обработка междурядий от сорной растительности. Разработанная технология позволит увеличить равномерность покрытия защитно-стимулирующими препаратами обрабатываемых растений до 96-99\% за счет использования аэрозоля, дисперсность частиц которого не превышает 50 мкм. Применение тоннельных укрытий уменьшит снос препаратов ветром, а значит, снизит их потерю. Совместное применение пестицидов и солей гуминовых кислот позволит нивелировать стресс от химической обработки растений. Кроме того, внедрение данной технологии позволит снизить энергоемкость операции по обработке растений, расходы ГСМ и повысит эфффективность использования машинно-тракторного парка за счет совмещения операций обработки растений защитно-стимулирующими препаратами с обработкой междурядий гербицидами для уничтожения сорной растительности.

Ключевые слова: способ обработки, пестициды, гуматы, баковые смеси, генератор горячего тумана, аэрозоли.

\section{Введение}

Современный способ ведения сельскохозяйственного производства невозможно представить без применения большого количества разнообразных ядохимикатов, которые применяются для борьбы с болезнями растений, их вредителями и сорной растительностью. Применение этих препаратов вызывает целый ряд негативных явлений: гибель почвенной микрофлоры, накопление ядов в сельскохозяйственной продукции, нарушение фризиологических фрункций растений. Известно, что пестициды обладают высокой фритотоксичностью не только по отношению к сорным, но и к культурным растениям. Многие из них вызывают замедление, а также видоизменение биохимических и физиологических процессов, протекающих в растительных организмах, снижают интенсивность фотосинтеза, уменьшают скорость поглощения элементов минерального питания. Такое негативное воздействие на обмен веществ обрабатываемого растения сопровождается общим угнетением его роста и развития, что в конечном итоге приводит к снижению продуктивности [1,2]. Наибольшее неблагоприятное воздействие на культурное растение оказывает обработка гербицидами. Фунгициды и инсектициды вызывают меньший химический стресс.

Многочисленные данные отечественных и зарубежных ученых свидетельствуют о том, что гуминовые удобрения защищают культурные растения от фитотоксического действия гербицидов, адсорбируют вредные примеси и пестициды в почве. Добавление в баковые смеси гуминовых препаратов позволяет усилить действие средств защиты растений, снизить стрессовую нагрузку на культурные растения, увеличить скорость разложения ядов в клетках самих растений. Кроме того, являясь стимуляторами роста, гуматы помогают растению нивелировать последствия химического стресса, значительно сократить время и силу его негативного воздействия и продолжить нормальную вегетацию $[3,4]$.
Современный уровень развития сельскохозяйственного производства предъявляет к технологиям и средствам механизации защиты растений все более высокие требования. Главным среди них является обеспечение качественной обработки культур с минимальным расходом рабочей жидкости.

Аэрозольная обработка является эффрективным способом защиты растений, который позволяет существенно снизить расход ядохимикатов, улучшить равномерность покрытия обрабатываемых поверхностей и значительно увеличить производительность процесса. Аэрозоли представляют собой частицы твердого (дымы) или жидкого (туманы) пестицида, размерность которых составляет от 1 до 50 мкм, взвешенные в воздухе. Туман и дым благодаря своей размерности обладают способностью легко проникать в крону растений и равномерно распределяться по всей обрабатываемой поверхности. Эта их способность значительно усиливает токсическое действие пестицида на вредные организмы. В результате данный вид химической обработки растений, по сравнению с опрыскиванием, в десятки раз уменьшает расход ядохимикатов, значительно увеличивает производительность и повышает качество обработки $[5,6]$. При всей эффективности аэрозольный способ обработки растений не лишен недостатков. К ним можно отнести трудноуправляемость процесса и большую вероятность сноса мелких частиц тумана ветром или восходящими потоками воздуха.

\section{Материалы и методы}

С целью повышения эффективности обработки растений была предложена технология аэрозольной обработки пропашных культур, позволяющая добиться равномерного покрытия растения защитно-стимулирующими препаратами, повысить их усвояемость культурами и тем самым повысить качество обработки. Предлагаемая технология обработки растений в рядках производится аэрозолем препаратов, создаваемым генератором горячего тумана, а для снижения химического стресса 
растений в баковую смесь для обработки пропашных культур совместно со средствами защиты растений добавляется раствор солей гуминовых кислот.

Создание аэрозоля защитно-стимулирующих препаратов осуществляется при помощи генератора горячего тумана и позволяет добиться лучшей равномерности обработки растений, так как образуемый аэрозоль (туман) будет заполнять всё пространство, образованное тоннельными укрытиями и тем самым покрывать растение целиком. Кроме того, использование тоннельных укрытий позволит уменьшить снос препарата ветром или восходящими потоками воздуха. Использование аэрозоля для обработки растений также увеличит степень усвоения препарата за счёт того, что дисперсность его частиц будет составлять менее 50 мкм, что меньше размера устьиц пропашных культур. При этом одновременно с обработкой культурных растений в рядках осуществляется обработка междурядий от сорной растительности с использованием системы ультрамалообъёмного опрыскивания. На рисунке 1 представлена схема установки для аэрозольной обработки пропашных культур для предложенного способа.

Технология аэрозольной обработки пропашных культур осуществляется следующим образом. Предварительно готовится рабочая баковая смесь защитно-стимулирующих препаратов, включающая в себя средства защиты растений и раствор солей гуминовых кислот. Подготовленная смесь заправляется в бак рабочего раствора 1, бак для раствора гербицидов 2 заправляется гербицидами. После этого осуществляется аэрозольная обработка растений: рабочая баковая смесь подаётся насосом 3 через эжектор 4 в жаровую трубу 5 парогенератора 6, где происходит её преобразование в аэрозоль дисперсностью менее 50 мкм, который по системе трубопроводов 7 поступает в тоннельные укрытия 8 и заполняет их. В результате этого растения, находящиеся в них, полностью покрывается аэрозолем защитно-стимулирующих препаратов.

Одновременно с этим из бака для раствора гербицидов 2 при помощи насоса 9 системы ультрамалообъёмного опрыскивания осуществляется подача гербицидов по системе трубопроводов 10 к форсункам 11, в результате чего происходит обработка междурядий от сорной растительности.

Для апробации разработанной технологии и проведения исследований по определению равномерности заполнения тоннелей и дисперсности получаемого аэрозоля использовался метод тепловых маяков. С этой целью была разработана и изготовлена лабораторная установка, представляющая собой макет тоннельного укрытия с размещёнными в нём маяками, обладающими большой тепловой инерционностью, которые были установлены внутри укрытия определенным образом (рис. 2).

Маяки закреплялись через каждые 50 мм на нитях, которые обладали малой теплопроводностью, тем самым образуя гирлянду. Полученные гирлянды подвешивались через 50 мм внутри тоннельного укрытия, тем самым создавая координатное пространство для определения температуры на различных его участках. Для изготовления маяков использовался свинец толщиной 1,50 мм, размер каждого маяка составлял $2 \times 5$ мм. Подача аэрозоля осуществлялась при помощи генератора горячего тумана марки BF-150. При помощи тепловизора марки RGKTL-80 фиксировалась термограмма маяков, закрепленных в укрытии.

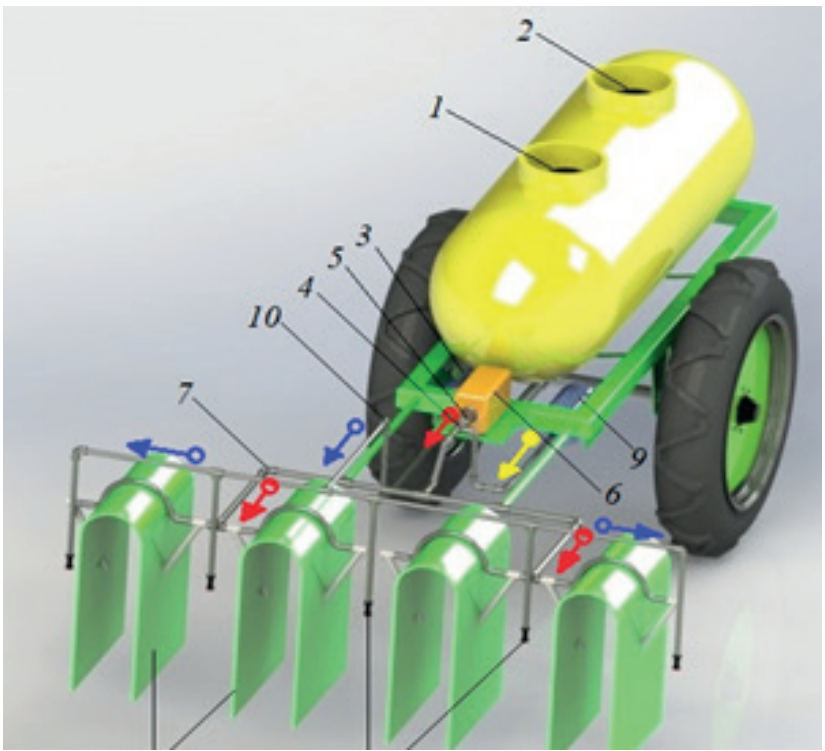

1 - бак рабочего раствора; 2 - бак для раствора гербицидов; 3 - насос; 4 - эжектор; 5 - жаровая труба;

6 - парогенератор; 7 - система трубопроводов;

8 - тоннельные укрытия; 9 - насос системы ультрамалообъёмного опрыскивания;

10 - система трубопроводов; 11 - форсунки

Рис. 1 - Схема установки для аэрозольной обработки пропашных культур

После установки гирлянд маяков через определённое расстояние в тоннельном укрытии производилась подача аэрозоля в течение определённого времени, тем самым осуществлялся нагрев пространства внутри тоннельного укрытия при помощи горячего тумана. Затем пространство внутри тоннельного укрытия фотографировалось при помощи тепловизора. Топография теплового поля фиксировалась на различных участках тоннельного укрытия.

При обработке растений по вегетации важным фактором, влияющим на усвояемость препарата, является также дисперсность получаемого аэрозоля. Для определения дисперсности аэрозоля в макет тоннельного укрытия устанавливался лабораторный штатив, имитирующий растение. На каждую лапку лабораторного штатива закреплялось по два предметных стекла таким образом, чтобы нижняя поверхность одного плотно прилегала к верхней поверхности другого, тем самым имитируя нижнюю и верхнюю поверхность листа. Расположение лабораторного штатива в тоннельном укрытии показано на рисунке 3. 


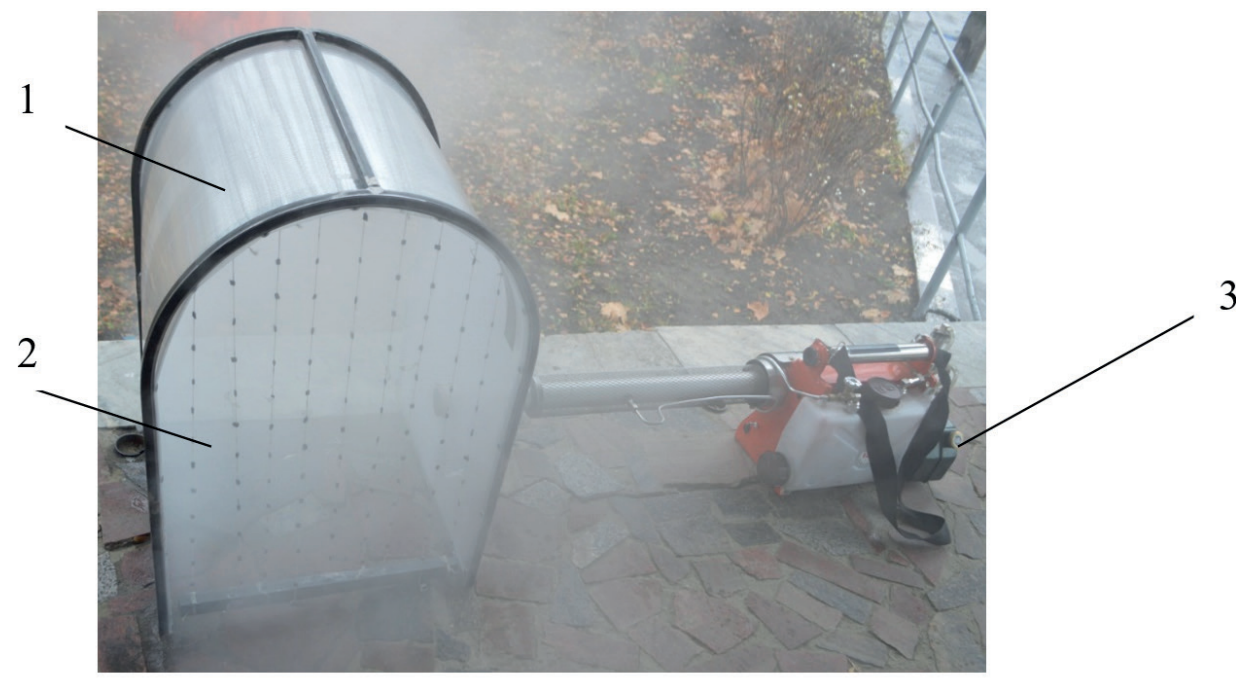

1 - макет тоннельного укрытия; 2 - гирлянда тепловых маяков; 3 - парогенератор

Рис. 2 - Общий вид лабораторной установки для аэрозольной обработки пропашных культур

1

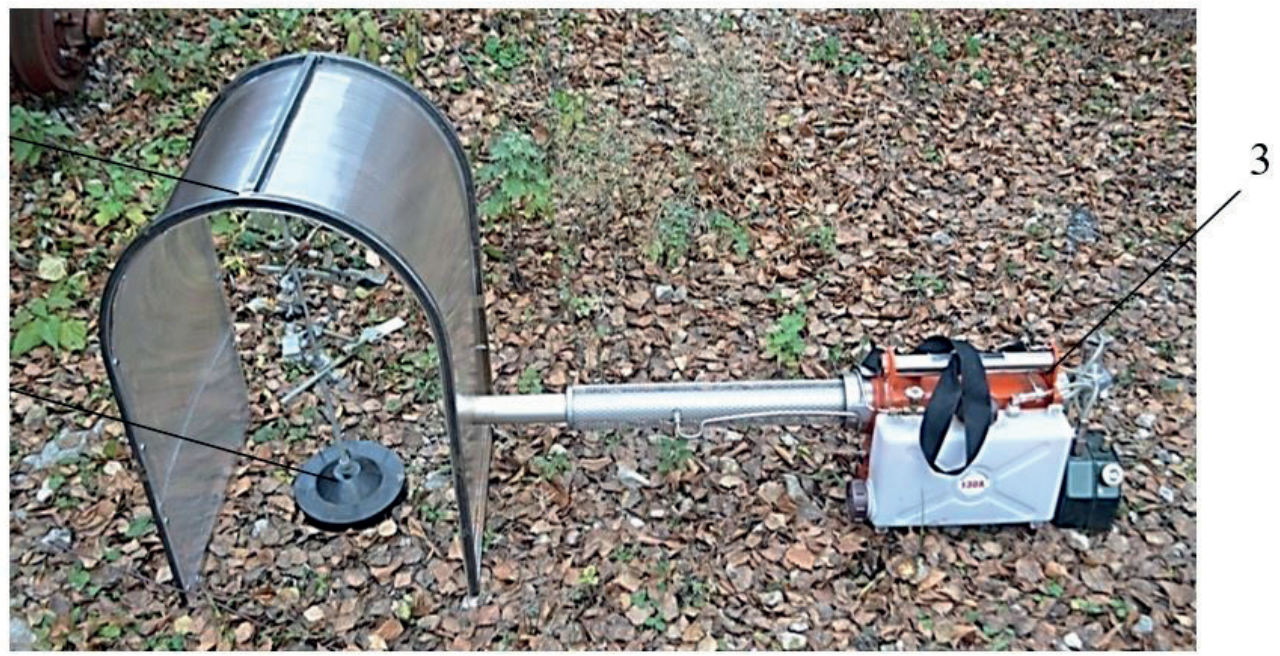

1 - макет тоннельного укрытия; 2 - лабораторный штатив с предметными стеклами; 3 - парогенератор

Рис. 3 - Общий вид расположения лабораторного штатива в тоннельном укрытии

Для определения размера капель и площади обрабатываемой поверхности растения использовался метод определения размера капель горячего тумана по солевому остатку [7]. С этой целью использовался 20\%-й раствор поваренной соли $(\mathrm{NaCl})$. Выбор данной концентрации был обусловлен коэффиициентом поверхностного натяжения и невозможностью образования насыщенного раствора. Время обработки аэрозолем соответствовало времени прохождения тоннельного укрытия над одним растением. После обработки предметных стекол горячим туманом производился их осмотр с использованием микроскопа марки «Микромед C1 LED».

Оценку размера капель аэрозоля вследствие испарения воды проводили из условия равенства массы соли $\mathrm{NaCl}$ в капле первоначального раствора и частицы после полного испарения. Большинство исследуемых частиц имели неправильную форму и являлись несферическими. Кроме того, ряд полученных образцов был сформирован из множества частиц. Поэтому для определения раз- меров капель аэрозоля использовали результаты статистического анализа. Для определения параметров каждого кристалла соли пользовались приведённым диаметром.

Результаты исследований и их обсуждение

В ходе экспериментальных исследований было установлено, что в процессе работы генератора горячего тумана в течение 5 секунд температура тепловых маяков увеличилась с $10^{\circ} \mathrm{C}$ до $15^{\circ} \mathrm{C}$ при температуре атмосферного воздуха $10{ }^{\circ} \mathrm{C}$ и его влажности 80\%; скорость воздушного потока не превышала 5 м/с. В процессе определения температуры маяков было установлено, что равномерность распределения горячего тумана по ширине тоннельного укрытия составляет от 96\% до 99\%. Результат распределения теплового поля, а также аэрозоля защитно-стимулирующих препаратов, приведен на рисунке 4. В результате фиксации термограмм тепловых маяков образовывалась топография распределения тепловых потоков тоннельного укрытия. 


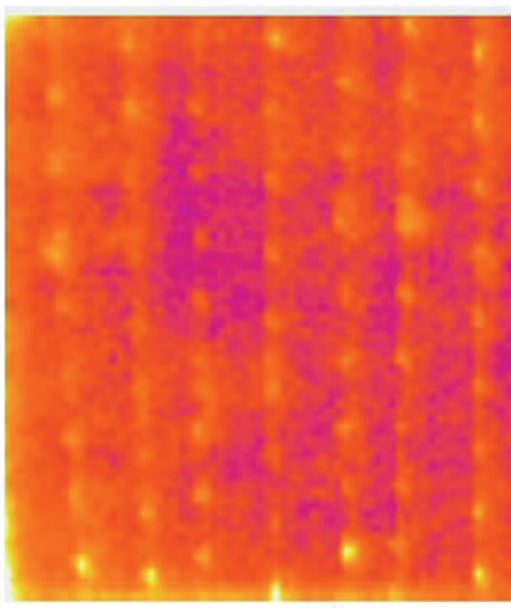

a)

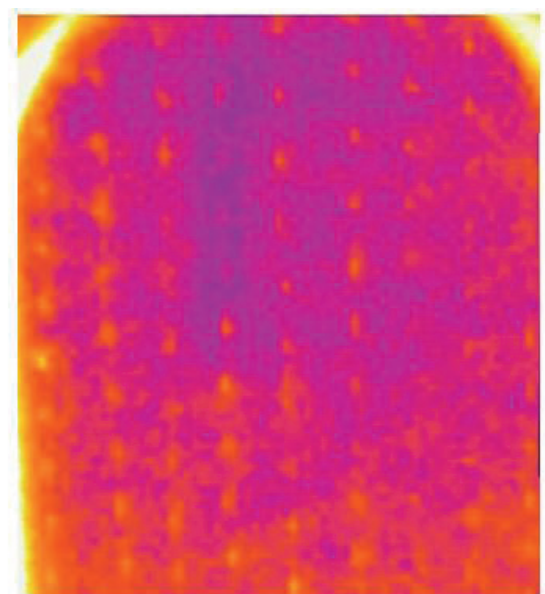

б)

a - распределение температурных маяков в центральной части тоннельного укрытия;

б - по краям тоннельного укрытия

Рис. 4 - Распределение температурного поля внутри тоннельного укрытия

Исследование распределения температуры показывает, что аэрозоль защитно-стимулирующих препаратов, полученный с использованием генератора горячего тумана, довольно равномерно распределяется в пределах камеры обработки. Это позволяет предполагать, что обработка растений в тоннельных укрытиях будет осуществляться равномерно.

Полученные экспериментальные данные с микроскопа марки «Микромед C1 LED» были обработаны в программе для анализа изображений,

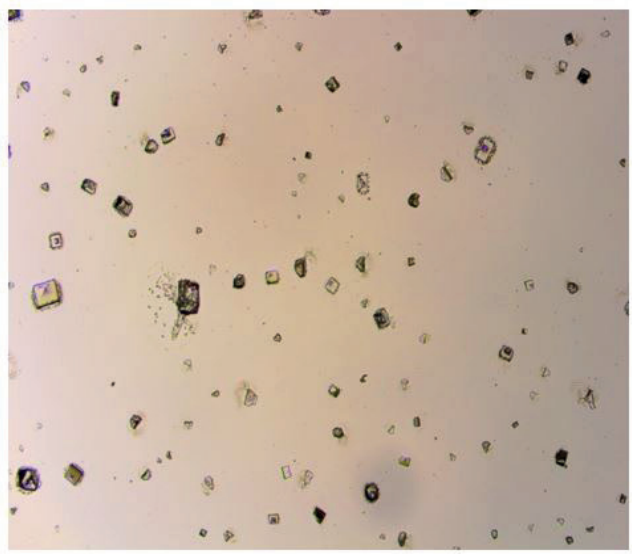

a) написанной на языке $\mathrm{C} / \mathrm{C}++$, с использованием библиотеки OpenCV 4.1.2. Данная разработка была реализована в бесплатно распространяемой среде Visual Studio 2019 Community в операционной системе Windows 10. С помощью обработки изображения алгоритмом Кэнни, который позволяет распознать границы объектов на основе изменений цветов, передаваемых в виде математической матрицы, были распознаны кристаллы соли на представленных данных с микроскопа (рис. 5).

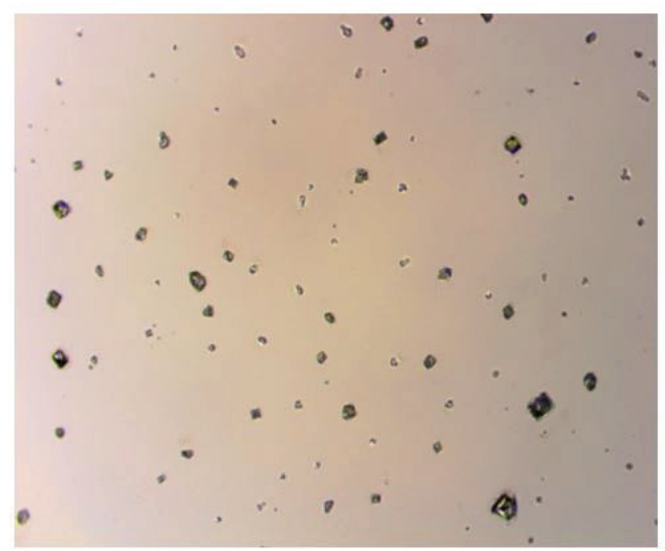

б)

a - предметное стекло, имитирующее верхнюю поверхность листа, б - предметное стекло, имитирующее нижнюю поверхность листа

Рис. 5 - Определение размерности капель по солевому остатку

Анализ полученных результатов выявил равномерное распределение кристаллов соли по обрабатываемой поверхности - коэффиициент вариации составил 8,2\%, средний размер кристаллов составляет 4,8 мкм, а средний диаметр капель горячего тумана - около 17 мкм.

Стоит отметить, что на предметных стеклах, имитирующих нижнюю поверхность листа, оседало 80-85\% капель по сравнению с количеством капель на стеклах, имитирующих верхнюю поверхность листа. Таким образом, полученные результаты свидетельствуют о том, что аэрозольная обработка пропашных культур в тоннельных укры- тиях позволяет добиться высокой равномерности покрытия растения защитно-стимулирующими препаратами. Так как экспериментально установлено, что дисперсность распыляемого аэрозоля составляет менее 50 мкм, а средний размер устьиц пропашных культур достигает 60 мкм, можно судить о высокой проницаемости и усвояемости защитно-стимулирующих препаратов, а значит, о повышении эффеективности обработки благодаря использованию данного способа.

Кроме того, при аэрозольной обработке культур отмечается снижение потерь ядохимикатов, что также связано с размерностью частиц аэрозоля и 
со способом его доставки к объекту обработки.

В процессе работы аэрозольного генератора возникают турбулентные потоки, благодаря которым и происходит доставка препарата к растению. При этом более крупные частицы аэрозоля находятся в центральной части потока и имеют большую инерционность. При встрече с препятствием они сталкиваются с ним и осаждаются на его передней поверхности. В то время как мелкие частицы имеют меньшую инерционность и при возникновении препятствия увлекаются воздушным потоком и огибают его, осаждаясь на его обратной стороне. Таким образом, благодаря наличию турбулентных потоков препараты доставляются к растению и осаждаются в самых труднодоступных его местах, чего не происходит при использовании других способов химической обработки, например, опрыскивания.

\section{Заключение}

Результаты проведенных исследований позволяют предположить, что технология аэрозольной обработки пропашных культур позволит повысить эффективность данной технологической операции за счет увеличения равномерности покрытия обрабатываемых растений защитно-стимулирующими препаратами до 96-99\% благодаря использованию аэрозоля с дисперсностью частиц не более 50 мкм и снизить потери препаратов от сноса ветром за счет применения тоннельных укрытий. Кроме того, включение в состав баковых смесей солей гуминовых кислот позволит нивелировать химический стресс растений от обработки ядохимикатами. Еще одним несомненным преимуществом предлагаемой технологии является совмещение операций обработки растений защитно-стимулирующими препаратами с обработкой междурядий гербицидами для уничтожения сорной растительности, что позволит снизить общую энергоемкость обработки, экономить ГСМ и эффрективнее использовать машинно-тракторный парк.

\section{Список литературы}

1. Рогозин, М. Ю. Экологические последствия применения пестицидов в сельском хозяйстве / М.Ю. Рогозин, Е. А. Бекетова. - Текст : электронный // Молодой ученый. - 2018. - №25. - С. 39-43. — URL: https:// moluch.ru/ archive/211/51593/ (дата обращения: 15.01.2020).

2. Саратовских, Е.А. Влияние пестицидов на физиологические процессы растений и микроор- ганизмов / Е.А. Саратовских. - Текст : непосредственный // Материалы Всероссийской научной конференции с международным участием и школы молодых ученых: Механизмы устойчивости растений и микроорганизмов к неблагоприятным условиям среды, 10-15 июля 2018 года. В 2-х частях. Рецензируемое научное издание. - Иркутск: Издательство Института географии им. В.Б. Сочавы СО РАН, 2018. - С. 1126-1134.- Библиогр.: с. 1133-1134 (23 назв.).

3. Тетерина, О.А. Аэрозольная обработка семенного зерна стимуляторами на основе гуматов / О.А. Тетерина, В.С. Тетерин, М.Ю. Костенко. - Текст : непосредственный // Материалы 67-ой Международной научно - практической конференции «Инновационные подходы к развитию агропромышленного комплекса региона», 18 мая 2016 года. Рецензируемое научное издание. - Рязань: Издательство Рязанского государственного агротехнологического университета имени П.А. Костычева, 2016. - С. 88-91. - Библиогр.: с. 90-91 (14 назв.).

4. Спиридонов, Ю.Я., Современное состояние проблемы применения гербицидов / Ю.Я Спиридонов, С.Г. Жемчужин. - Текст : непосредственный // Агрохимия. - 2011. - № 9. - С. 82-94. - Рез. англ. - Библиогр.: с. 88 -94 (157 назв.).

5. Зинченко, В.А. Химическая защита растений: средства, технологии и экологическая безопасность / В.А. Зинченко. - 2-е изд., перераб. и доп. - Москва: Колосс, 2012. - 127 с. - ISBN 978-5-95320816-1 - Текст : непосредственный.

6. Анализ технических средств для внесения биологических удобрений и биопрепаратов / И.Н. Горячкина, М.Ю. Костенко, Г.К. Рембалович [и др.]. - Текст : непосредственный // Материалы 70-й Международной научно-практической конференции «Вклад университетской аграрной науки в инновационное развитие агропромышленного комплекса», 23 мая 2019 года. Рецензируемое научное издание. - Рязань: Издательство Рязанского государственного агротехнологического университета имени П.А. Костычева, 2019. - С. 124128.- Библиогр.: с. 128 (10 назв.).

7. Ишматов, А.Н. Исследование развития высокодисперсного аэорозоля жидкости с учетом влияния слабоиспаряемой примеси / А.Н. Ишматов, Б.И. Ворожцов. - Текст : непосредственный // Краткие сообщения по физике ФИАН. - Москва. № 1 - 2010. - С. 22-27. - Библиогр.: с. 26 (5 назв.).

\section{METHOD FOR AEROSOL SPRAYING OF TILLED CROPS}

Teterin Vladimir S., candidate of technical sciences, Head of the Chair №2, Senior Researcher, Labiogiant@mail.ru

Gapeeva Natalya N., candidate of biological sciences, leading researcher, gapeevann@mail.ru

Panfyorov Nikolay S., candidate of technical sciences, Vice-director for Innovations and Development of pilot-scale production, nikolaj-panfyorov@yandex.ru

Institute of Technical Support of Agriculture - branch of the Federal State Budgetary Scientific Institution "Federal Scientific Agroengineering Center VIM"

Organo-mineral fertilizers (humates) are a powerful means of protecting plants and soils against environmental pollutions. One of the main and valuable features of humic preparations lies in their compatibility with pesticides. At the same time, humates improve the effect of pesticides, that allows to reduce doses of chemical weed and 
pest killers by $20-40 \%$. It helps to improve agroecological situation and provides an opportunity to minimize expenditures for expensive pesticides. Besides that, the inclusion of humates in tank mixtures helps to reduce the negative impact of toxic chemicals. In order to improve the efficiency of the application of humate-containing protective and stimulating substances in plant treatment, the authors have developed a method for aerosol spraying of tilled crops. The method involves spraying plants with protective and stimulating substances in the form of an aerosol, being supplied from a hot mist generator in a tunnel plant shelter. The solution of humic acid salts is introduced in a tank mixture for plant treatment together with plant protecting agents. Antiweed treatment of the space between the rows is carried out using the ultra-low volume spraying system, simultaneously with spraying plants in the rows. The developed technology will increase the uniformity of covering plants with protective and stimulating substances to $96-99 \%$ by using aerosol, characterized by the dispersity of particles of up to 50 microns. The use of tunnel plant shelters will diminish the waste of preparations through reducing the effect of the wind. The combined use of pesticides and humic acid salts will diminish the stress from the chemical treatment of plants. In addition, the introduction of this technology will lead to the reduction of energy, fuels and lubricants oils consumption in carrying out plant treatment, and provide more rational use of agricultural machines and equipment through combining such operations as spraying plants with protective and stimulating substances and treating the space between the rows with herbicides for weed destruction.

Key words: treatment method, pesticides, humates, tank mixtures, hot mist generator, aerosols.

\section{Literatura}

1. Rogozin, M. YU. Ekologicheskie posledstviya primeneniya pesticidov v sel'skom hozyajstve / M.YU. Rogozin, E. A. Beketova. - Tekst : elektronnyj // Molodoj uchenyj. - 2018. - №25. - S. 39-43. - URL: https:// moluch.ru/ archive/211/51593/ (data obrashcheniya: 15.01.2020).

2. Saratovskih, E.A. Vliyanie pesticidov na fiziologicheskie processy rastenij i mikroorganizmov / E.A. Saratovskih. - Tekst : neposredstvennyj // Materialy Vserossijskoj nauchnoj konferencii s mezhdunarodnym uchastiem i shkoly molodyh uchenyh: Mekhanizmy ustojchivosti rastenij i mikroorganizmov k neblagopriyatnym usloviyam sredy, 10-15 iyulya 2018 goda. V 2-h chastyah. Recenziruemoe nauchnoe izdanie. - Irkutsk: Izdatel'stvo Instituta geografii im. V.B. Sochavy SO RAN, 2018. - S. 1126-1134.- Bibliogr.: s. $1133-1134$ (23 nazv.).

3. Teterina, O.A. Aerozol'naya obrabotka semennogo zerna stimulyatorami na osnove gumatov / O.A. Teterina, V.S. Teterin, M.YU. Kostenko. - Tekst : neposredstvennyj // Materialy 67-oj Mezhdunarodnoj nauchno - prakticheskoj konferencii «Innovacionnye podhody k razvitiyu agropromyshlennogo kompleksa regiona», 18 maya 2016 goda. Recenziruemoe nauchnoe izdanie. - Ryazan': Izdatel'stvo Ryazanskogo gosudarstvennogo agrotekhnologicheskogo universiteta imeni P.A. Kostycheva, 2016. - S. 88-91. - Bibliogr.: s. 90-91 (14 nazv.).

4. Spiridonov, YU.YA., Sovremennoe sostoyanie problemy primeneniya gerbicidov / YU.YA Spiridonov, S.G. ZHemchuzhin. - Tekst : neposredstvennyj // Agrohimiya. - 2011. - № 9. - S. 82-94. - Rez. angl. Bibliogr.: s. $88-94$ (157 nazv.).

5. Zinchenko, V.A. Himicheskaya zashchita rastenij: sredstva, tekhnologii i ekologicheskaya bezopasnost' / V.A. Zinchenko. - 2-e izd., pererab. i dop. - Moskva: Koloss, 2012. - 127 s. - ISBN 978-5-9532-0816-1 - Tekst : neposredstvennyj.

6. Analiz tekhnicheskih sredstv dlya vneseniya biologicheskih udobrenij i biopreparatov / I.N. Goryachkina, M.YU. Kostenko, G.K. Rembalovich [i dr.]. - Tekst: neposredstvennyj//Materialy 70-jMezhdunarodnojnauchnoprakticheskoj konferencii «Vklad universitetskoj agrarnoj nauki v innovacionnoe razvitie agropromyshlennogo kompleksa», 23 maya 2019 goda. Recenziruemoe nauchnoe izdanie. - Ryazan': Izdatel'stvo Ryazanskogo gosudarstvennogo agrotekhnologicheskogo universiteta imeni P.A. Kostycheva, 2019. - S. 124-128.-Bibliogr.: s. 128 (10 nazv.).

7. Ishmatov, A.N. Issledovanie razvitiya vysokodispersnogo aeorozolya zhidkosti s uchetom vliyaniya slaboisparyaemoj primesi / A.N. Ishmatov, B.I. Vorozhcov. - Tekst : neposredstvennyj // Kratkie soobshcheniya po fizike FIAN. - Moskva. - № 1 - 2010. - S. 22-27. - Bibliogr.: s. 26 (5 nazv.).

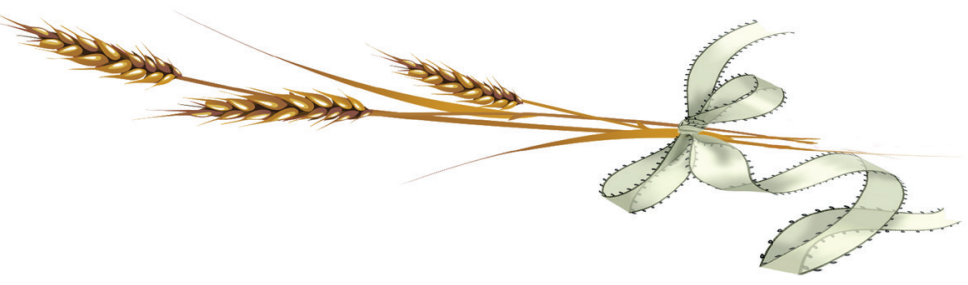




\title{
АНАЛИЗ ПРОЦЕССА ВЫГРУЗКИ КЛУБНЕЙ ИЗ ТРАНСПОРТНОГО АГРЕГАТА С УСОВЕРШЕНСТВОВАННЫМ САМОСВАЛЬНЫМ КУЗОВОМ
}

\author{
ФИлюшин Олег Владимирович, студент магистратуры 1 курса aushaniev@inbox.ru \\ КОСТЕНКО Михаил Юрьевич, д-р техн. наук, дочент, профрессор кафердры «ТМиРМ» \\ УСПЕНСКИЙ Иван Алексеевич, д-р техн. наук, профрессор, зав. кафеедрой «TЭТ», yuival@rambler.ru \\ ЮХИн Иван Александрович, д-р техн. наук, доцент, зав. кафредрой «ATTuT», yuival@rambler.ru \\ УШАНЕВ Александр Игоревич, cm. преподаватель кафеедры «TЭТ», aushaniev@inbox.ru \\ Рязанский государственный агротехнологический университет имени П.А. Костычева
}

Как известно из проведенных ранее исследований, удельный вес перевозок тракторным транспортом в РФ составляет 50-60\% от общего объема внутрихозяйственных перевозок в сельском хозяйстве. Возрастающая потребность в перевозках сельскохозяйственных грузов требует увеличения производительности внутрихозяйственного транспорта, повышения его экономичности, безопасности и комфорта. Уровень повреждений является одним из важнейших факторов, определяющих себестоимость продукции. Известно, что стоимость поврежденной сельскохозяйственной продукции на 30-50\% меньше, чем неповрежденной. По данным ряда исследователей потери при хранении поврежденной при транспортировании продукции могут достигать 50-60\% от общей массы. Поэтому снижение повреждений на пути следования сельскохозяйственной продукции «полепотребитель», в частности, на заключительной стадии доставки сельскохозяйственной продукуции - разгрузке, является важной народно-хозяйственной задачей. В связи с вышеизложенным нами была сорормулирована цель работы: снижение повреждений картофреля на внутрихозяйственных перевозках применением тракторного прицепа с усовершенствованным самосвальным кузовом для минимизации транспортных издержек. При разгрузке катящийся клубень имеет большую кинетическую энергию в сравнение со скользящим. Поэтому для гашения кинетической энергии используется перегрузочное устройство. В результате проведения теоретических исследований ВП транспортного агрегата с усовершенствованной конструкцией самосвального кузова установлено, что клубневой ворох не падает вниз, а поступает на роликовый транспортер (причем ролики снабжены выступами из упругого материала), что в совокупности сводит возможность травмирования плодов при разгрузке к минимуму (не более 1,6 \%).

Ключевые слова: механизированная уборка картофреля, повреждение клубней при транспортировке, катящийся клубень, перемещение насыпи клубней, качение клубня.

\section{Введение}

При механизированной уборке картофеля около 20-40\% клубней получают ушибы. В результате повреждений клубней при транспортировке в самосвалах потери углеводов возрастают в 2,5-3 раза по сравнению с транспортировкой в таре, потери витамина С увеличиваются примерно на $10 \%$.

Поэтому важно оценить качество клубней картофеля перед закладкой на длительное хранение, что позволит сократить потери картофеля.

\section{Объект исследований}

В настоящее время применяются разрушающие и неразрушающие способы оценки качества клубней картофеля. В первом случае тестируемые клубни для выявления повреждений разрезаются на дольки или подвергаются очистке со снятием определенной толщины слоя. Во втором случае клубни сохраняют целостность. Не разрушающие способы определения повреждений получили наибольшее распространение, так как они дают возможность автоматизировать процессы сортировки клубней. В основу этих способов положены оптические, рентгеновские, акустические, электрические и тепловые свойства клубней картофеля. Недостатком данных способов является то, что они количественно оценивают повреждения клубней, но не дают качественной оценки $[1,2]$.

Следует отметить, что выявление внешних повреждений эффрективно осуществляется с помо- щью оптических систем, установление внутренних повреждений затруднено из-за скрытости ушибов под относительно неповрежденной поверхностью клубня. При длительном хранении внутренние повреждения являются дополнительной причиной потерь питательных веществ и порчи картофеля $[3,4,5]$.

\section{Теоретические исследования процесса выгрузки клубней}

При выгрузке клубней картофреля из кузова транспортного средства, клубни могут скатываться по насыпи или скользить по днищу кузова из-за ограничений других клубней. В своем движении клубни приобретают определенную скорость, которая будет способствовать увеличению их повреждений. Рассмотрим движение клубня по насыпи картофеля (наклонной плоскости) под действием силы тяжести [6, 7].

Воспользуемся теоремой об изменении кинетической энергии

$$
\mathrm{T}_{2}-\mathrm{T}_{1}=\mathrm{A}_{(\mathrm{c})}
$$

где Т1 - начальная кинетическая энергия клубня $\left(\mathrm{T}_{1}=0\right)$, Дж;

$\mathrm{T}_{2}$ - конечная кинетическая энергия клубня, Дж;

$\mathrm{A}_{(\mathrm{c})}$ - работа внешних сил, Дж.

Так как клубень перед выгрузкой находится в покое $(\mathrm{T} 1=0)$, запишем выражение для кинетической энергии клубня

() Филюшин О. В., Костенко М. Ю., Успенский И. А., Юхин И. А., Ушанев А.И., 2020 г. 
$\mathrm{T}=\mathrm{T}_{2}=\frac{1}{2} M V_{\mathrm{\kappa} л}^{2}+\frac{1}{2} J \omega^{2}$

где М - масса клубня картофеля, кг;

$\mathrm{V}_{\text {кл }}$ - скорость центра тяжести клубня, м/с;

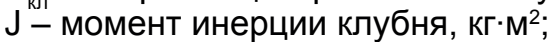

$\omega$ - угловая скорость клубня, рад/с.

При исследовании движения клубня введем допущение, что клубень имеет форму шара, тогда момент инерции определяется выражением

$$
J=\frac{2}{5} M r^{2}
$$

где $r$ - радиус шара, м.

Так как точка касания шара (клубня) является мгновенным центром скоростей, то можно записать

$\mathrm{V}_{\mathrm{kл}}=\omega \cdot \mathrm{r}$

Подставив полученные значения в формулу 2 , получим

$\mathrm{T}=\frac{1}{2} M V_{\text {кл }}^{2}+\frac{2}{5} M r^{2} \cdot\left(\frac{V_{\text {кл }}}{r}\right)^{2}=\frac{9}{10} M V_{\text {кл }}^{2}$

При качении клубня по насыпи картофеля сила трения всегда приложена в точке контакта и поэтому не совершает работу. Исходя из этого, определим работу силы тяжести

$\mathrm{A}_{(\mathrm{c})}=G \cdot h_{\text {кл }}$

где $\mathrm{G}$ - сила тяжести клубня ( $\mathrm{G}=\mathrm{Mg}), \mathrm{H}$;

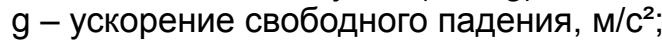

$\mathrm{h}_{\text {кл }}$ - высота перемещения клубня, м.

Высота перемещения клубня по насыпи зависит от угла естественного откоса насыпи картофеля и длины кузова (рис. 1)

$$
h_{\text {кл }}=L \sin \psi
$$

где $L$ - длина кузова транспортного средства (насыпи в кузове), м;

$\Psi$ - угол естественного откоса насыпи клубней картофеля.

Подставив в выражение (1) значения величин из выражений (5), (6 и (7), получим

$$
\frac{9}{10} M V_{\text {кл }}^{2}=M \cdot g \cdot L \cdot \sin \psi
$$

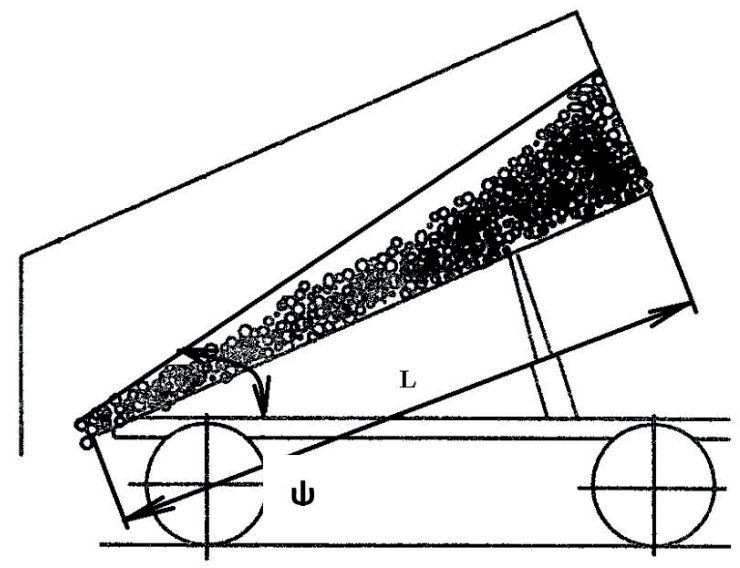

Рис. 1 - Общий вид перемещения насыпи клубней картофеля из кузова транспортного средства при разгрузке

Исходя из исследований контактного динамического взаимодействия клубня картофеля с поверхностью, следует, что скорость клубня $\mathrm{V}_{\text {кп }}$ должна быть меньше допустимого значения скорости удара $\mathrm{V}_{d}$ (табл. 1).

Таблица 1 - Допускаемые высоты падения и скорости удара клубня

\begin{tabular}{|c|c|c|}
\hline \multicolumn{1}{|c|}{ Поверхность } & Высота падения, м & Скорость удара $\mathrm{V}_{\mathrm{d}}$, $/ \mathrm{c}$ \\
\hline сталь, дерево & $0,3-0,5$ & $1,9-2,5$ \\
\hline прорезиненная решетка & $0,5-0,7$ & $5,6-7,5$ \\
\hline свободный клубень & - & $3,8-5$ \\
\hline несвободный клубень & & \\
\hline к=2 & $0,1-0,2$ & $2,7-3,6$ \\
\hline к=1 & $0,37-0,66$ & $2,7-3,6$ \\
\hline к=0,5 & $0,87-1,6$ & $4,1-5,2$ \\
\hline
\end{tabular}

Примечание: к - это отношение радиусов клубней $\mathrm{R}_{1}$ (клубень, который падает) на $\mathrm{R}_{2}$ (клубень, на который падает).

Выразим значение скорости клубня

$$
V_{\text {кл }}=\sqrt{\frac{10 g \cdot L \cdot \sin \psi}{9}}
$$

Таким образом, получена зависимость скорости скатывающегося по насыпи клубня от длины кузова транспортного средства (рис. 2)

Подставив следующие данные: $\psi=45$ град и
$\mathrm{L}=4,08$ м (конструктивные параметры самосвального прицепа 2 ПТС-4) в формулу (9), получим:

$$
V_{\text {кл }}=\sqrt{\frac{10 \cdot 9,81 \cdot 4,08 \cdot \sin 45}{9}}=5,61
$$

Расчетное значение $\mathrm{V}_{\text {кл }}=5,61 \mathrm{~m} / \mathrm{c}$ соответствует только допустимому значению скорости падения клубней на резиновую поверхность (табл. 1). 
В противном случае высока вероятность повреждения плода [8].

Следует отметить, что при выгрузке максимальная высота перемещения клубня достигается при определенном угле подъема кузова, что будет соответствовать максимально возможной скорости корнеплода.

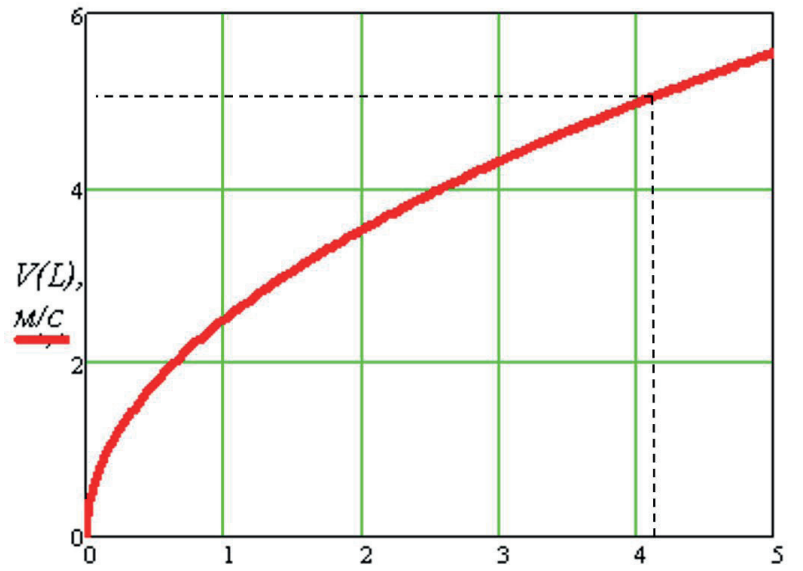

Рис. 2- Зависимость скорости качения клубня от длины насыпи

Рассмотрим движение клубня без возможности вращения (при движении насыпи целиком). Аналогично, как и в предыдущем случае, кинетическая энергия скользящего клубня равна

$\mathrm{T}=\mathrm{T}_{2}=\frac{1}{2} M V_{\text {кл1 }}^{2}$

где $\mathrm{V}_{\text {кл1 }}$ - скорость клубня при поступательном движении, м/с;

При поступательном движении клубня работа внешних сил будет определяться не только силой тяжести, но и силой трения клубня о днище кузова $\mathrm{A}_{(\mathrm{c})}=\left(G \sin \alpha-F_{\mathrm{Tp}}\right) L$

где $\alpha$ - угол подъема кузова транспортного средства;

$\mathrm{F}_{\text {тр }}$ - сила трения $\left(\mathrm{F}_{\text {тр }}=\mathrm{fN}\right), \mathrm{H}$;

$\mathrm{f}$ - коэфффициент трения клубней картофеля о днище кузова;

$\mathrm{N}$-сила нормального давления $(\mathrm{N}=\mathrm{G} \cos \alpha), \mathrm{H}$.

С учетом выражений (1), (10) и (11), получим

$\frac{1}{2} M V_{\text {кл } 1}^{2}=(M g \sin \alpha-f M g \cos \alpha) L$

Преобразовав выражение (12), получим

$V_{\text {кл } 1}=\sqrt{2 g \cdot L \cdot(\sin \alpha-f \cos \alpha)}$

Построим графрик скорости клубней в програмme MathCad (рис. 3)

Подставив следующие данные: $\alpha=45$ град и $\mathrm{L}=4,08$ м (конструктивные параметры самосвального прицепа 2 ПТС-4) и f=0,56 (коэффрициент трения скольжения клубня о сталь) в формулу (13), получим:

$V_{\text {кл1 }}=\sqrt{2 \cdot 9,81 \cdot 4,08 \cdot(\sin 45-0,56 \cos 45)}=4,99 \mathrm{M} / \mathrm{c}$

Из анализа соответствующих кузовов транспортных средств определяем: скорость клубней при сходе с днища кузова прицепа 2ПТС-4 составляет

при качении клубня - около 4,2-5,7 м/с;

при скольжении клубня - 3,8-5,2 м/с в зависимости от угла подъема кузова.

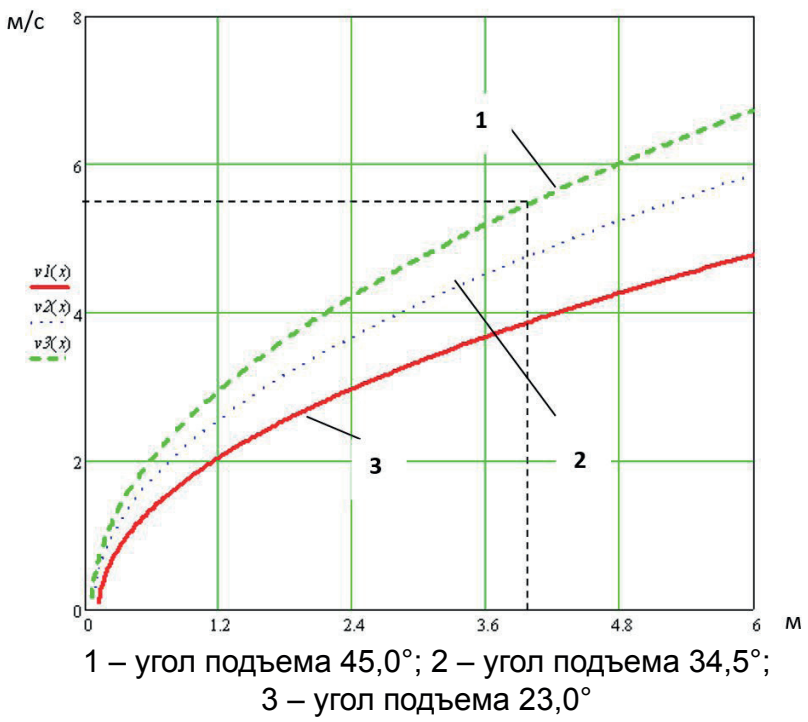

Рис. 3 - Зависимость скорости скольжения клубня от длины кузова прицепа 2-ПТС-4 при разных углах а подъема кузова

Анализ полученных результатов показывает, что кинетическая энергия клубня на момент схода клубня с кузова составляет:

для качения - 2,36 Дж;

для скольжения -1,875 Дж.

Таким образом, катящийся клубень имеет большую кинетическую энергию в сравнении со скользящим. Поэтому для гашения кинетической энергии используется перегрузочное устройство.

При выгрузке клубней картофеля из кузова, оборудованного перегрузочным устройством, клубни на момент попадания на перегрузочное устройство обладают некоторой скоростью $[9,10]$. При встрече с роликами перегрузочного устройства возникают ударные взаимодействия. Рассмотрим удар вращающегося клубня о вращающийся ролик (рис. 4)

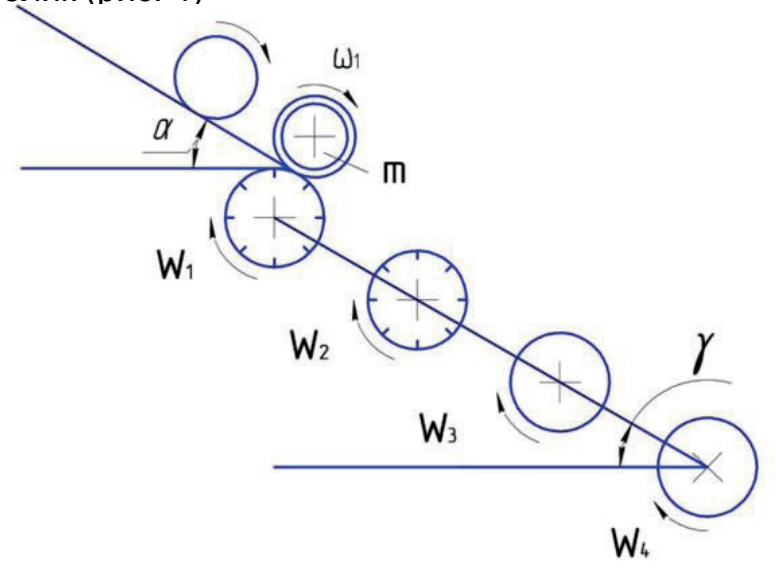

Рис. 4 - Расчетная схема к определению угловой скорости клубня при взаимодействии с вращающимися роликами 
Так как ролики перегрузочного устройства находятся на уровне днища кузова и вращаются с встречным направлением по отношению к клубню, применим теорему об изменении моментов количества движения к взаимодействию клубня с роликом. Ударные импульсы клубня и ролика запишутся как:

$I_{1}\left(\omega_{2}-\omega_{1}\right)=S \cdot r_{1}$

$$
I_{2}\left(w_{2}-w_{1}\right)=S \cdot r_{2}
$$

где I1;12 - моменты инерции клубня и ролика соответственно, кг' $\mathrm{M}^{2}$;

$\omega_{1} ; \omega_{2}-$ угловая скорость клубня до удара $и$ после удара, рад/с;

$\mathrm{w}_{1} ; \mathrm{W}_{2}$ - угловая скорость ролика до удара и после удара, рад/c;

$S$ - импульсы, кг.м/с;

$\mathrm{r}_{1} ; \mathrm{r}_{2}$ - радиусы клубня и ролика, м.

Так как неударные нагрузки - вес клубня, сила трения, реакции его взаимодействий значительно меньше ударных сил, то ими пренебрегаем.

Приравняв ударные импульсы из выражений (14) и (15), получим

$$
-I_{1}\left(\omega_{2}-\omega_{1}\right) r_{2}+I_{2}\left(w_{2}-w_{1}\right) r_{1}=0
$$

Скорости точки контакта в момент ударного взаимодействия клубня и ролика соответственно равны:

$V_{1}=\omega_{1} \cdot r_{1}$

$V_{2}=\omega_{2} \cdot r_{1}$

$U_{1}=w_{1} \cdot r_{2}$

$U_{2}=w_{2} \cdot r_{2}$

где $\mathrm{V}_{1} ; \mathrm{V}_{2}$ - окружная скорость клубня до и после удара, м/с; удара, $\mathrm{M} / \mathrm{c}$

$\mathrm{U}_{1} ; \mathrm{U}_{2}$ - окружная скорость ролика до и после

По аналогии с поступательным движением запишем выражение коэффрициента восстановления для вращательного движения:

$$
k=\frac{U_{2}-V_{2}}{U_{1}-V_{1}}=\frac{w_{2} \cdot r_{2}-\omega_{2} \cdot r_{1}}{w_{1} \cdot r_{2}-\omega_{1} \cdot r_{1}}
$$

Тогда окружные скорости клубня и ролика после соударения будут:

$$
w_{2} \cdot r_{2}-\omega_{2} \cdot r_{1}=-k \omega_{1} \cdot r_{1}+k w_{1} \cdot r_{2}
$$

Преобразовав выражение (16), получим,

$I_{1} w_{2} \cdot r_{2}-I_{2} \omega_{2} \cdot r_{1}=-I_{1} \omega_{1} \cdot r_{1}-I_{2} w_{1} \cdot r_{2}$

Решив совместно выражения (22) и (23), получим угловую скорость клубня после ударного воздействия

$$
\omega_{2}=\frac{-I_{2} \cdot r_{1} \cdot r_{2} \cdot(1+k) \cdot w_{1}+\left(-I_{1} \cdot r_{2}^{2}+I_{2} \cdot r_{1}^{2} \cdot k\right) \omega_{1}}{I_{1} \cdot r_{2}^{2}-I_{2} \cdot r_{1}^{2}}
$$

Определим изменение угловой скорости $\omega 2 \mathrm{c}$ учетом значений моментов инерции клубня и ролика, коэффициента восстановления в зависимости от угловой скорости вальца.

Анализируя график угловой скорости (рис. 5), можно видеть, что скорость клубня при движении по роликам существенно зависит от их угловой скорости и начальной угловой скорости клубня.

Так как направление вращения клубня при движении и ролика противоположны, то после каждого ролика будет происходить замедление вращения клубня, а затем и изменение вращения на противоположное. Это будет способствовать замедлению клубня при переходе его с кузова на перегрузочное устройство, а затем движению клубня со скоростью вращения роликов.

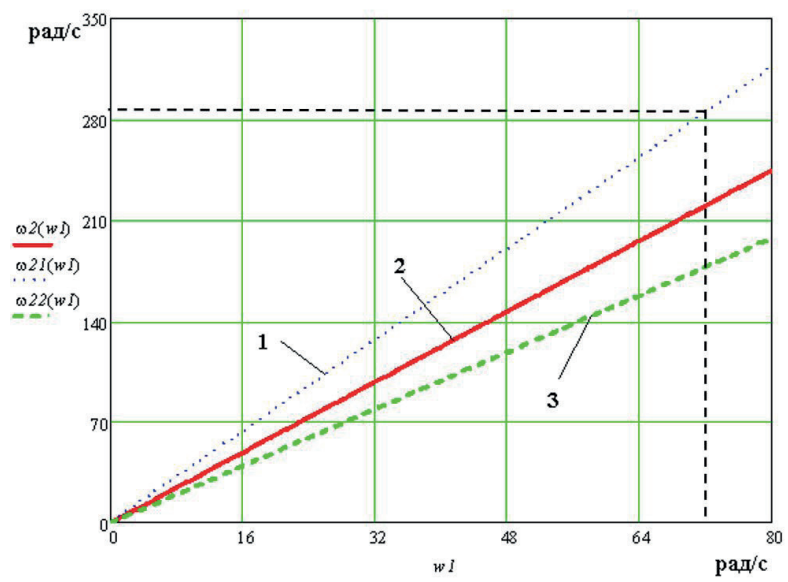

1 - диаметр клубня 40 мм; 2 - диаметр клубня 50 мм; 3 - диаметр клубня 60 мм

Рис. 5 - Зависимость угловой скорости клубня от угловой скорости вращения ролика при различных значениях диаметра клубня

При недостаточном количестве клубней на перегрузочном устройстве и малом диаметре клубней возможно вращение клубня между соседними роликами. Рассмотрим условия выхода клубней из зазора (рис. 6)

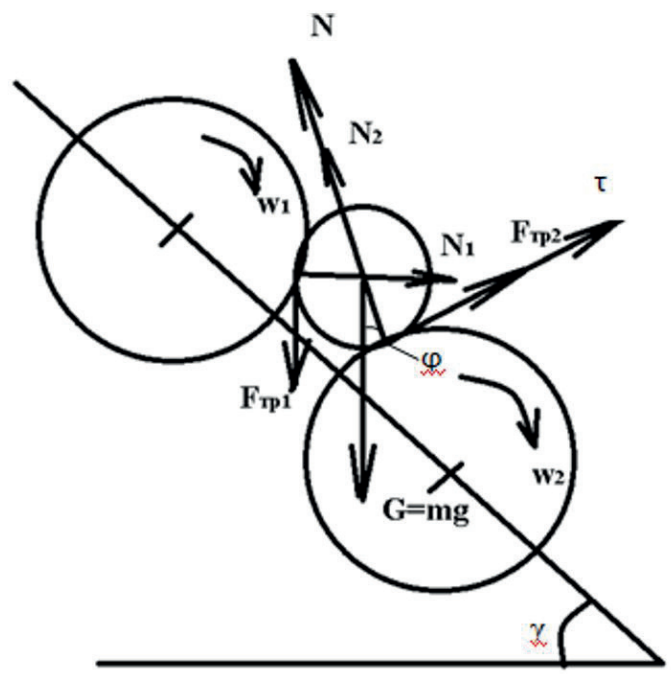

Рис. 6 - Расчетная схема к взаимодействию клубня картофеля с соседними роликами

На клубень действуют реакции опор и сила тяжести, силы инерции не учитываем, тогда диффференциальное уравнение запишется в виде

$m \frac{d V_{\tau}}{d t}=G \sin \xi-F_{\text {тр }}$ 
где $\mathrm{G}$ - сила тяжести клубня, ( $\mathrm{G}=\mathrm{mg}), \mathrm{H}$;

$\mathrm{m}$ - масса клубня, кг;

$\mathrm{g}$ - ускорение свободного падения, м/ $\mathrm{c}^{2}$;

$\mathrm{F}_{\text {тр }}$ - сила трения клубня о ролик

$$
\left(F_{\text {тр }}=f_{k} \frac{N_{1}}{r_{1}}=f_{k} \frac{G \cos \xi}{r_{1}}\right), \mathrm{H}
$$

$\mathrm{f}_{\mathrm{k}}$ - коэфффициент трения качения клубня о ролик $\mathrm{f}_{\mathrm{k}}=0,5-0,8 \mathrm{мm}$;

$\mathrm{r}_{1}$ - радиус клубня, м;

$\xi$ - угол между направлением силы тяжести и касательной в месте контакта клубня с роликом, град.

Подставив значения в уравнение (25) и разделив на $\mathrm{m}$, получим

$\frac{d V_{\tau}}{d t}=g \sin \xi-f_{k} \frac{g \cos \xi}{r_{1}}$

Разделим переменные и проинтегрируем

$\int_{v_{0}}^{v} d V_{\tau}=g \int_{0}^{t}\left(\sin \xi-f_{k} \frac{\cos \xi}{r_{1}}\right) d t$

После подстановки пределов интегрирования получим:

$V-V_{0}=g\left(\sin \xi-f_{k} \frac{\cos \xi}{r_{1}}\right) t$

или

$V=V_{0}+g t\left(\sin \xi-f_{k} \frac{\cos \xi}{r_{1}}\right)$

где $\mathrm{t}$ - время взаимодействия, с.

Угол $\xi$ зависит от соотношения геометрических показателей клубня и роликов перегрузочного устройства, которые связаны соотношением:

$d \geq \frac{D(1-\sin \varphi)+c}{\sin \varphi}$

где d - диаметр клубня,м;

D - диаметр ролика, м;

c - величина зазора между роликами, м;

$\varphi$ - угол между углом наклона перегрузочного устройства и касательной в точке контакта клубня с роликом, град.

Соотношение углов для перегрузочного устройства выглядит следующим образом:

$\xi=\gamma-\varphi$

где ү - угол наклона перегрузочного устройства.

Таким образом, подставив выражение (31) в выражение (29), получим:

$V=V_{0}+g t\left(\sin (\gamma-\varphi)-f_{k} \frac{\cos (\gamma-\varphi)}{r_{1}}\right)$

Построим зависимость скорости клубня от времени нахождения на перегрузочном устройстве для клубня диаметром 50 мм.

Из рисунка 7 видно, что клубень постепенно замедляется при движении по перегрузочному устройству. С уменьшением угла наклона перегрузочного устройства ү скорость клубня будет уменьшаться. При заданной скорости клубня угол наклона составляет 27 градусов, число роликов - 16 .

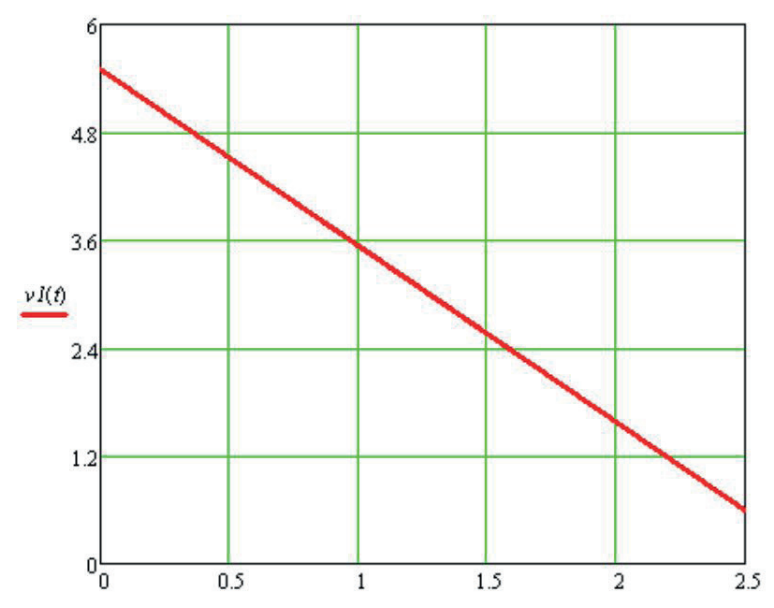

Рис. 7 - Зависимость скорости клубня от времени нахождения на перегрузочном устройстве для клубня диаметром 50 мм

\section{Заключение}

Из анализа соответствующих кузовов транспортных средств определяем: скорость клубней при сходе с днища кузова прицепа 2ПТС-4 составляет:

при качении клубня - около 4,2-5,7 м/с;

при скольжении клубня - 3,8-5,2 м/с в зависимости от угла подъема кузова.

Анализ полученных результатов показывает, что кинетическая энергия клубня на момент схода клубня с кузова составляет:

для качения 2,36 Дж;

для скольжения 1,875 Дж.

Таким образом, катящийся клубень имеет большую кинетическую энергию в сравнение со скользящим. Поэтому для гашения кинетической энергии используется перегрузочное устройство.

В результате проведения теоретических исследований транспортного агрегата с усовершенствованной конструкцией самосвального кузова установлено, что клубневой ворох не падает вниз, а поступает на роликовый транспортер (причем ролики снабжены выступами из упругого материала), что в совокупности сводит возможность травмирования клубней при разгрузке к минимуму (не более 1,6 \%).

\section{Список литературы}

1. Theoretical studies of the damage process of easily damaged products in transport vehicle body during the on-farm transportation / Byshov N.V. and other // ARPN Journal of Engineering and Applied Sciences. 2018. T. 13. № 10. pp. 3502-3508.

2. Improving the performance parameters of vehicles for intrafarm transport in the agro-industrial complex/ N.V. Byshov et al 2019 IOP Conf. Ser.: Earth Environ. Sci. 341012145.

3. Increasing the Safety of Agricultural Products During Its Transportation and Unloading / Byshov N.V. and other // (2018) ACM International Conference Proceeding Series, pp. 176-179.

4. Пат. 161488, RU, МПК B60R 9/00; B60P 1/00. Навесное перегрузочное устройство для самосвального кузова транспортного средства / Филю- 
шин О.В., Голиков А.А., Успенский И.А., Юхин И.А. [и др.]; - Опубл. 20.04.2016, бюл. № 11.

5. Перспективные направления и технические средства для снижения повреждений клубней при машинной уборке картофеля [Текст] / Н. В. Бышов, С. Н. Борычев, Г. К. Рембалович [и др.] // Техника и оборудование для села. - 2013. - № 8 (194) - С. 22-24.

6. Повышение надежности технологического процесса и технических средств машинной уборки картофеля по параметрам качества продукции [Текст] / Г.К. Рембалович, И. А. Успенский, Р. В. Безносюк [и др.] // Техника и оборудование для села. - 2012. - № 3. -С. 6-8.

7. Анализ процесса выгрузки сельскохозяйственной продукции из усовершенствованного кузова тракторного прицепа / С.В. Колупаев, И.А. Юхин, И.А. Успенский и др. // Политематический сетевой электронный научный журнал Кубанского государственного аграрного университета (Научный журнал КубГАУ) [Электронный ресурс]. - Краснодар: КубГАУ, 2015. - №08(112). С. 778 801. - IDA [article ID]: 1121508058. - Режим доступа: http://ej.kubagro.ru/2015/08/pdf/58.pdf, 1,5 у.п.л.

8. Бышов, Н.В. Основные требования к техническому уровню тракторов, транспортных средств и прицепов на долгосрочную перспективу / Н.В. Бышов, С.Н. Борычев, И. А. Успенский, И.А. Юхин, Н.В. Аникин, С.В. Колупаев, К.А. Жуков / Перера- ботка и управление качеством сельскохозяйственной продукции: доклады Международной научнопрактической конференции 21 - 22 марта 2013г. - Минск : Изд-во БГАТУ, 2013. - с. 200-202

9. Полункин, А.А. Снижение травмируемости сельскохозяйственной продукции при перевозке транспортными средствами с самосвальными кузовами /А.А. Полункин, О.В. Филюшин, И.А. Успенский, Г.К. Рембалович, И.А. Юхин // Энергоэффективные и ресурсосберегающие технологии и системы: сборник научных трудов международной научно-практической конференции, посвященной памяти доктора технических наук, профессора Ф.Х. Бурумкулова / редкол.: Сенин П.В. [и др.]. Саранск: ФГБОУ ВО«Национальный исследовательский мордовский государственный университет им. Н.П. Огарева», 2016, С. 376-382.

10. Бышов Н.В. Пути дальнейшей модернизации транспортных средств для АПК / Бышов Н.В., Борычев С.Н., Успенский И.А., Юхин И.А., Рябчиков Д.С., Кулик С.Н. // Политематический сетевой электронный научный журнал Кубанского государственного аграрного университета (Научный журнал КубГАУ) [Электронный ресурс]. - Краснодар: КубГАУ, 2016. - №09(123). - Режим доступа: http://ej.kubagro.ru/2016/09/pdf/09.pdf, 1,688 у.п.л. - IDA [article ID]: 1221608009. http://dx.doi. org/10.21515/1990-4665-123-009

\title{
ANALYSIS OF THE PROCESS OF UNLOADING TUBERS FROM A TRANSPORT UNIT WITH AN IMPROVED DUMP BODY
}

\author{
Filushin Oleg V., 1st year master's student \\ Uspensky Ivan Y., doctor of technical Sciences, Professor, head of the TET Department \\ Yukhin Ivan A., doctor of technical Sciences, associate Professor, head of the Department "Attit" \\ Ushanew Alexander I., the educational master of the Department "TET", aushaniev@inbox.ru \\ Ryazan state agrotechnological University named after P. A. Kostychev
}

When mechanized potato harvesting, about $20-40 \%$ of tubers get bruised. As a result of damage to tubers during transportation in dump trucks, the loss of carbohydrates increases by 2.5...3 times compared with transportation in containers; the loss of vitamin C increases by about $10 \%$. Therefore, it is important to assess the quality of potato tubers before laying for long-term storage, which will reduce potato losses. Currently, destructive and non-destructive methods are used to assess the quality of potato tubers. In the first case, the tested tubers are cut into slices to detect damage or are cleaned to remove a certain layer thickness. In the second case, the tubers remain intact. Non-destructive methods for determining damage are most widespread, as they make it possible to automate the processes of sorting tubers. These methods are based on the optical, $x$-ray, acoustic, electrical and thermal properties of potato tubers. The disadvantage of these methods is that they quantify damage to tubers, but do not give a qualitative assessment. It should be noted that the detection of external injuries is effectively carried out using optical systems, the establishment of internal injuries is difficult due to the concealment of bruises under the relatively intact surface of the tuber. When stored for a long time, internal damage is an additional cause of loss of nutrients and spoilage of potatoes. Thus, a rolling tuber has a greater kinetic energy compared to a sliding tuber. Therefore, an overload device is used to extinguish the kinetic energy. Graph 7 shows that the tuber gradually slows down as it moves through the reloading device. As the angle of the reloading device decreases, the tuber speed will decrease. At the set speed of the tuber, the angle of inclination will be 27 degrees, the number of rollers is 16.

Key words: mechanized potato harvesting, damage to tubers during transportation, rolling tuber, moving the mound of tubers, rolling tuber.

\section{Literatura}

1. Theoretical studies of the damage process of easily damaged products in transport vehicle body during the on-farm transportation / Byshov N.V. and other // ARPN Journal of Engineering and Applied Sciences. 2018. T. 13. № 10. pp. 3502-3508.

2. Improving the performance parameters of vehicles for intrafarm transport in the agro-industrial complex/ N.V. Byshov et al 2019 IOP Conf. Ser.: Earth Environ. Sci. 341012145.

3. Increasing the Safety of Agricultural Products During Its Transportation and Unloading / Byshov N.V. and 
other // (2018) ACM International Conference Proceeding Series, pp. 176-179.

4. Pat. 161488, RU, MPK B60R 9/00; B60P 1/00. Navesnoe peregruzochnoe ustrojstvo dlya samosval'nogo kuzova transportnogo sredstva / Filyushin O.V., Golikov A.A., Uspenskij I.A., YUhin I.A. [i dr.]; - Opubl. 20.04.2016, byul. № 11.

5. Perspektivnye napravleniya i tekhnicheskie sredstva dlya snizheniya povrezhdenij klubnej pri mashinnoj uborke kartofelya [Tekst] / N. V. Byshov, S. N. Borychev, G. K. Rembalovich [i dr.] // Tekhnika i oborudovanie dlya sela. - 2013. - № 8 (194) - S. 22-24.

6. Povyshenie nadezhnosti tekhnologicheskogo processa i tekhnicheskih sredstv mashinnoj uborki kartofelya po parametram kachestva produkcii [Tekst] / G.K. Rembalovich, I. A. Uspenskij, R. V. Beznosyuk [i dr.] // Tekhnika i oborudovanie dlya sela. - 2012. - № 3. -S. 6-8.

7. Analiz processa vygruzki sel'skohozyajstvennoj produkcii iz usovershenstvovannogo kuzova traktornogo pricepa / S. V. Kolupaev, I.A. YUhin, I.A. Uspenskij i dr. // Politematicheskij setevoj elektronnyj nauchnyj zhurnal Kubanskogo gosudarstvennogo agrarnogo universiteta (Nauchnyj zhurnal KubGAU) [Elektronnyj resurs]. Krasnodar: KubGAU, 2015. - №08(112). S. 778 - 801. - IDA [article ID]: 1121508058. - Rezhim dostupa: http://ej.kubagro.ru/2015/08/pdf/58.pdf, 1,5 u.p.l.

8. Byshov, N.V. Osnovnye trebovaniya k tekhnicheskomu urovnyu traktorov, transportnyh sredstv i pricepov na dolgosrochnuyu perspektivu / N.V. Byshov, S.N. Borychev, I. A. Uspenskij, I.A. YUhin, N.V. Anikin, S.V. Kolupaev, K.A. ZHukov / Pererabotka i upravlenie kachestvom sel'skohozyajstvennoj produkcii: doklady Mezhdunarodnoj nauchno-prakticheskoj konferencii 21 - 22 marta 2013g. - Minsk : Izd-vo BGATU, 2013. - s. 200-202

9. Polunkin, A.A. Snizhenie travmiruemosti sel'skohozyajstvennoj produkcii pri perevozke transportnymi sredstvami s samosval'nymi kuzovami /A.A. Polunkin, O.V. Filyushin, I.A. Uspenskij, G.K. Rembalovich, I.A. YUhin // Energoeffektivnye i resursosberegayushchie tekhnologii i sistemy: sbornik nauchnyh trudov mezhdunarodnoj nauchno-prakticheskoj konferencii, posvyashchennoj pamyati doktora tekhnicheskih nauk, professora F.H. Burumkulova / redkol.: Senin P.V. [i dr.]. Saransk: FGBOU VO«Nacional'nyj issledovatel'skij mordovskij gosudarstvennyj universitet im. N.P. Ogareva», 2016, S. 376-382.

10. Byshov N.V. Puti dal'nejshej modernizacii transportnyh sredstv dlya APK / Byshov N.V., Borychev S.N., Uspenskij I.A., YUhin I.A., Ryabchikov D.S., Kulik S.N. // Politematicheskij setevoj elektronnyj nauchnyj zhurnal Kubanskogo gosudarstvennogo agrarnogo universiteta (Nauchnyj zhurnal KubGAU) [Elektronnyj resurs]. - Krasnodar: KubGAU, 2016. - №09(123). - Rezhim dostupa: http://ej.kubagro.ru/2016/09/pdf/09. pdf, 1,688 u.p.I. - IDA [article ID]: 1221608009. http://dx.doi.org/10.21515/1990-4665-123-009 


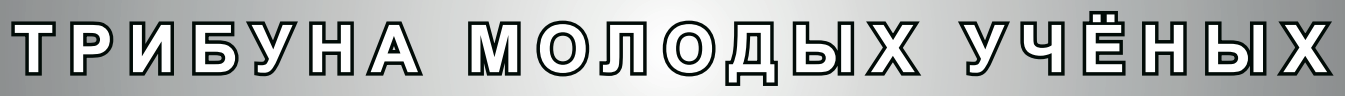

Удк: 57.065:636. 082

DOI 10.36508/RSATU.2020.45.1.020

\section{ГЕНЕТИЧЕСКАЯ ИДЕНТИФИКАЦИЯ КАК КРИТЕРИЙ СОВПАДЕНИЙ С ДАННЫМИ ПЕРВИЧНОГО УЧЕТА ЖИВОТНЫХ НА ТЕРРИТОРИИ УФО}

КАБИЦКАЯ Яна Александровна, аспирант ФГБОУ ВО ГАУ Северного Зауралья, уanakabickaуа@ yandex.ru

КАЛАШНИКОВА Любовь Александровна, д-р.биол.наук, професссор, ФГБНУ Всероссийский научно-исследовательский институт племенного дела, lakalashnikova@mail.ru

БОЙКО Елена Григорьевна, канд. биол. наук, доцент, ректор ФГБОУ ВО ГАУ Северного Зауралья, egboyko@yandex.ru

КАЛАШНИКОВ Александр Евгеньевич, канд. биол. наук, ФГБНУ Всероссийский научно-исследовательский институт племенного дела, aekalashnikov@уandex.ru

Для организации селекционно-племенной работы необходимо уточнение данных о родстве потомков крупного рогатого скота молочного и мясного направлений продуктивности при помощи молекулярно-генетических методов. Для осуществления этой задачи производилось сравнение данных первичного учета о родстве животных из информационно-аналитической системы (ИАС) СЕЛЭКС с менделевским наследованием генотипов от родителей потомкам, определенных при помощи ДНК тестирования. В качестве определения родства использовался простой и доступный метод анализа микросателлитных локусов ядерной ДНК. Для выполнения исследований создан и систематизирован банк образцов ДНК животных (крупный рогатый скот молочного и мясного направлений продуктивности) в количестве 4716 голов. Показана степень ошибочных записей в родословной потомков по данным первичного учета и результатов генотипирования на адаптированной панели 15 микросателлитных участков ядерного генома животных предприятий Тюменской и Курганской областей, а также ХМАО-Югра. Из 531 «троек» (мать-потомок-отец) животных молочного направления продуктивности выявлено не менее 88\% совпадений по обоим родителям. По родителям для черно-пестрой породы выявлено до $3 \%$ ошибочных записей в родословной потомков, для голштинской - до 11\%. Для мясных пород животных величина ошибок по генетической идентификации для абердин-ангус составила до 10\% и герефрорд - до 25\%. Установлено, что микросателлиты являются инструментом для определения достоверности происхождения по международному стандарту и проверки данных первичной регистрации зоотехнических данных и генетической идентификации крупного рогатого скота молочного и мясного направлений продуктивности.

Ключевые слова: достоверность происхождения, микросателлиты, генетическая идентификация, ошибки учета, ошибки регистрации, СЕЛЭКС, ISAG, ICAR.

\section{Введение}

Генетическая идентификация, а именно определение достоверности происхождения, является неотъемлемой частью единой системы идентифиикации племенных животных.

В мировой практике генетическую идентифрикацию и выявление ошибок регистрации в записях первичного учета животных проводят с помощью панели микросателлитных локусов, соответствующей международным стандартам в рамках рекомендаций ISAG/ICAR [13-14]. Проведение селекционных мероприятий на уровне ДНК имеет ряд преимуществ по сравнению с традиционными методами [1-4,6].

Отсутствие в Российской Федерации единой унифицированной методики по определению генетической идентификации племенных животных свидетельствует о необходимости и целесообразности разработки единых методик генотипирования в области племенного животноводства. Некоторые научно-исследовательские институты и коммерческие организации используют собственные разработки, применяя закрытые методики исследования.

Несовпадение первичного учета с данными по генотипированию животных является допустимым в селекции при показателе до 5-10\% несоответствий потомства заявленным родителям. Выявление ошибок позволяет уточнить родственные связи индивидуумов для дальнейшего формирования матриц родства, расчета величин племенной ценности животных, а также для исследований механизмов передачи наследуемых признаков от родителей к потомкам.

Формирование матриц родства в единой системе хранения генотипов является основой работы при оценке животных при помощи процедур BLUP (наилучший линейный неискаженный прогноз) [5].

Матрица родства позволяет рассчитать наследуемость при передаче генетических признаков между родственными животными для дальнейшей оценки их реализации в потомстве. Уточнение ма-

() Кабицкая Я. А., Калашникова Л. А., Бойко Е. Г., Калашников А. Е., 2020 г. 
трицы родства при помощи микросателлитного анализа и SNP маркеров представляет необходимый этап подготовки данных по генетическим признакам продуктивности, экстерьеру, здоровью животных для дальнейшего их анализа и оценки животных по потомству [5]. Важным для заводчика племенного скота является точное определение достоверности происхождения животных согласно международным стандартам, соблюдение нормативно-правовой базы, а также исправление ошибок первичного зоотехнического учёта данных [12].

Таким образом, для рационального ведения селекционно-племенной работы в Российской Федерации, а также для реализации генетического материала и племенных животных необходимо учитывать достоверность данных первичного зоотехнического учета. Также следует перейти на стандарты ICAR/ISAG при проведении генетической экспертизы методами молекулярно-генетического анализа по микросателлитным маркерам и однонуклеотидным заменам (SNP).

В связи с вышеизложенным, выполнение данной работы, посвященной генетической идентификации как критерия совпадений с данными первичного учета животных на территории УФО является не только актуальной, но и необходимой.

Для достижения поставленной цели решались следующие задачи:

1) разработать универсальный метод генетической идентификации животных в соответствии с международными консорциумами животноводов и сертификации ICAR/ISAG (Международный союз генетики животных/Международный комитет записи о животных);

2) выявить ошибки первичного учета и результатов генотипирования по микросателлитным участкам генома животных молочного и мясного направлений продуктивности предприятий Тюменской и Курганской областей, а также ХМАО-Югра;

3) выявить ошибки эксперимента, связанные с качеством теста по генетической идентификации некоторых пород крупного рогатого скота молочного и мясного направлений продуктивности предприятий Тюменской и Курганской областей, а также ХМАО-Югра.

\section{Объекты и методы}

Генетический банк ДНК сформирован из проб крови 4716 животных, отобранных в ряде предприятий Тюменской (АО «Приозерное», ООО «Бизон», ЗАО «Падунское», АО «ПЗ «Учхоз ГАУ Северного Зауралья», ООО «ЗапСибХлебИсеть», ООО «Герефорд») и Курганской (ООО «Суерь») областях, а также ХМАО-Югра (ООО «Башмаков»). В анализ были включены образцы ДНК животных следующих пород: голштинской (2091 голова), чернопестрой породы (513 голов), салерс (115 голов), обрак (1600 голов), абердин-ангус (175 голов) и герефорд (222 головы).

Данные первичного учета животных по родству получали из ИАС СЕЛЭКС (ООО «Плинор») [7]. Для выявления ошибок учёта проводили генетическую идентификацию животных при помощи микросателлитного анализа, согласно международным стандартам ISAG/ICAR (Международный союз генетики животных/Международный комитет записей о животных) (https://strbase.nist.gov/ cattleSTRs.htm) в лабораториях (центрах), имеющих свидетельство по данному виду деятельности (https://goo.gl/uM7Pxy, https://goo.gl/y4uWDH, https://goo.gl/KAJfzv, https://goo.gl/epHT5R) [10].

\section{Экспериментальная часть}

Геномную ДНК выделяли из жидкой крови животных с использованием ионообменной смоль «Chelex 100» (Bio-Rad, США) и коммерческого набора реагентов «ДНК Экстран» (Синтол, Россия). Качество ДНК проверяли электрофоретически в 2\%-м агарозном геле. Концентрацию ДНК измеряли на флуориметре Qubit3 (Thermo Fisher, США) с помощью набора dsDNA BR (Thermo Fisher, США) и программного обеспечения прибора. Генетическую идентификацию реализовали с применением коммерческих наборов (Гордис, Россия), содержащих панель 15 микросателлитных участков ядерного генома животных по 15 локусам (ЕTH3, INRA023, TGLA227, TGLA126, TGLA122, SPS115, ETH225, TGLA53, BM2113, BM1824, ETH10, CSSM66, ILSTS006) (https://goo.gl/LxCD53) [10]. ПЦР проводили на амплификаторе ProFlex 96Well PCR System (Applied Biosystems, Сингапур). Разделение продуктов амплификации осуществляли согласно протоколу производителя на секвенаторе 3500 (Thermo Fisher Scientific, США).

Достоверность происхождения определяли по закону наследования Менделя о передаче наследственной информации (менделевское наследование), представленной молекулярными маркерами между предполагаемыми родителями и потомками, по совпадению родительских аллелей и аллельных вариантов потомка [9]. Определение достоверности происхождения по SNP осуществляется при помощи модели менделевского наследования по Фишер-Райту [11], аналогично определению достоверности происхождения по микросателлитным локусам.

\section{Результаты}

Проведено сравнение данных первичного учета и результатов генотипирования, с выявлением артефактов и интерпретацией результатов молекулярно-генетического анализа животных молочного и мясного скота ряда хозяйств Тюменской и Курганской областей, а также ХМАО-Югра. Проверка ошибочных записей родословной потомков проведена сравнением генотипов «троек» - \{отец - мать - потомок\} животных по микросателлитным локусам и данными первичного учета.

Показатели ошибочных записей первичного учета и выявления достоверности происхождения в «тройках» животных молочного скота представлены в таблице 1. Выборки животных формировались по породам и отдельно по «тройкам» животных. 
Таблица 1 - Показатели ошибочных записей по данным первичного учета и выявления достоверности происхождения в «тройках» животных молочного направления продуктивности

\begin{tabular}{|l|c|c|c|}
\hline Порода & $\begin{array}{c}\text { Количество исследо- } \\
\text { ванных животных }\end{array}$ & $\begin{array}{c}\text { Количество «троек» } \\
\text { животных }\end{array}$ & $\begin{array}{c}\text { \% несоответствий по } \\
\text { генотипам в «тройках» } \\
\text { животных по отцу }\end{array}$ \\
\hline Черно-пестрая & 302 & 67 & до 3 \\
\hline Голштинская & 395 & 531 & до 11 \\
\hline
\end{tabular}

В результате проверки данных первичного учёта и подтверждения достоверности происхождения у 598 «троек» животных молочного скота было получено 531 (88\%) совпадение по обоим родителям. Ошибочные данные в «тройках» животных по матери выявлены у голштинской породы, для черно- пестрой породы такие отсутствуют.

В таблице 2 показан диапазон несоответствий генетической идентификации 4716 голов молоч-

ного и мясного скота. Ошибочные данные получены для 4 локусов мультиплексной панели крупного рогатого скота. Стоит отметить, что максимальный диапазон несоответствий выявлен для локусов Csrm60 и Tgla53. Ошибки для Tgla53 наблюдались во всех породах, за исключением пород салерс и обрак, причем наименьшие значения ошибочных данных были у последних пород.

Таблица 2 - Диапазон несоответствий генетической идентификации по отдельным локусам микросателлитных участков генома животных молочного и мясного направлений продуктивности

\begin{tabular}{|c|c|c|c|c|c|}
\hline \multirow{2}{*}{ Порода } & \multirow{2}{*}{$\begin{array}{c}\text { Кол-во } \\
\text { исследованных } \\
\text { животных }\end{array}$} & \multicolumn{4}{|c|}{ \% несоответствий по локусам } \\
\hline & & Tgla227 (\%) & Csrm60 (\%) & Ist6 (\%) & tgla53 $(\%)$ \\
\hline \multicolumn{6}{|c|}{ Тюменская область, ХМАО-Югра } \\
\hline Черно-пестрая & 513 & - & \multirow{2}{*}{\multicolumn{2}{|c|}{ частично не генотипированы }} & до 14 \\
\hline Голштинская & 2091 & до 6 & & & до 24 \\
\hline Обрак & 1600 & - & до 1 & до 0,3 & - \\
\hline Салерс & 115 & - & - & - & - \\
\hline Герефорд & 222 & - & до 25 & до 20 & до 24 \\
\hline \multicolumn{6}{|c|}{ Курганская область } \\
\hline Абердин-ангус & 175 & - & до 1 & - & до 10 \\
\hline
\end{tabular}

Таким образом, тестирование животных позволило определить достоверность происхождения скота некоторых пород молочного и мясного крупного рогатого скота: черно-пестрой, голштинской, обрак, абердин-ангус, гересорд и салерс, выращиваемых в Тюменской и Курганской областях, а также ХМАО-Югра.

Анализ учета подтверждения достоверности происхождения по родителям проводится по совпадению аллелей матери, отца и потомка (отмечено шрифттами: стандартный и курсив). Об-

щепринято, что если аллели матери и отца не присутствуют у потомка, то они не являются его родителями. Если у потомка присутствует в конкретном локусе аллель одного из родителей, то второй родитель не является его родителем (отмечено жирным шрифтом). Также не допускается ошибка при определении аллелей более чем в одном локусе, либо ошибка определения более чем в одном локусе из панели $[8,11]$. Пример такого сравнения приведен в таблице 3 .

Таблица 3 - Аллельные комбинации исследуемых «троек» образцов - предполагаемых родителей

\begin{tabular}{|c|c|c|c|c|}
\hline \multicolumn{7}{|c|}{$\left(\mathrm{F}_{1}+\mathrm{F}_{2}\right)$ и потомков $\left(\mathrm{F}_{1-1} n \mathrm{~F}_{1-2}\right)$} \\
\hline Образец/локус & $\mathrm{F}_{1}$ - мать & Потомок $\mathrm{F}_{1-1}$ & Потомок $\mathrm{F}_{1-2}$ & $\mathrm{~F}_{2}$ - отец \\
\hline ETH3 & 117,117 & 117,129 & $117, \mathbf{1 1 7}$ & 129,129 \\
\hline CSSM66 & 183,189 & 183,189 & $183, \mathbf{1 9 3}$ & 185,189 \\
\hline INRA006 & 202,210 & 210,214 & 202,214 & 214,214 \\
\hline BM1818 & 262,262 & 262,264 & 262,266 & 264,266 \\
\hline ILIST6 & 288,292 & 288,292 & 292,292 & 292,294 \\
\hline TGLA227 & 89,91 & 89,97 & 89,95 & 93,97 \\
\hline TGLA126 & 115,117 & 115,117 & 117,117 & 117,117 \\
\hline TGLA122 & 143,163 & 143,183 & 143,183 & 149,183 \\
\hline SPS115 & 248,248 & 248,254 & 248,248 & 252,254 \\
\hline ETH225 & 144,148 & 148,150 & 144,148 & 148,150 \\
\hline TGLA53 & 160,162 & 162,166 & 160,162 & 166,186 \\
\hline
\end{tabular}


Продолжение таблицы 2

\begin{tabular}{|c|c|c|c|c|}
\hline CSRM60 & 92,100 & 92,102 & 92,102 & 102,102 \\
\hline BM2113 & 125,137 & 125,135 & 135,137 & 135,139 \\
\hline BM1824 & 178,180 & 180,188 & 178,180 & 180,188 \\
\hline ETH10 & 209,219 & 217,219 & 209,217 & 217,223 \\
\hline
\end{tabular}

Необходимо отметить, что генетическая экспертиза достоверности происхождения всегда осуществляется только при наличии генетического материала обоих родителей и потомка. В противном случае, при наличии информации об одном из родителей снижается вероятность определения родства на $50 \%$. Если в базе данных присутствует генотип ранее исследованного индивида, либо этот генотип присутствует в каталоге производителя, полученный согласно протоколу ISAG/ICAR, то в дальнейшем его можно использовать для проведения генетической экспертизы.

Оценка (или прогноз, если потомки ещё не родились) генетической племенной ценности проводится только внутри оцениваемой популяции и осуществляется только при известных родственных взаимоотношениях в популяции до начала и во время оценки племенной ценности по BLUP (наилучший линейный неискаженный генетический прогноз). При оценке BLUP должна существовать генетическая связь между животными из различных хозяйств.

Матрица родства определяет родственные взаимоотношения и её расчёт проводится по племенным карточкам учёта, с обязательным уточнением по молекулярным маркерам. Это позволяет в дальнейшем отследить передачу генетических признаков между животными. Определение матрицы родства с помощью молекулярно-генетических методов исследования является неотъемлемой частью прогноза оценки племенной ценности и геномной оценки. Определение родства только по первичному учету без генетического уточнения приводит к накапливанию ошибок и превышению допустимого порога достоверности при BLUP.

Анализ полученных электрофореграмм показал наличие ряда артефактов, приводящих к ошибочному определению аллелей, которые в дальнейшем исключались из расчетов. Наиболее опасной ошибкой является детекция дополнительного пика, синтезированного вследствие присоединения ДНК-полимеразы к дополнительным основаниям (nontemplated) к концу синтезированной последовательности, неточный синтез праймеров либо не качественная их очистка (ПААГ), которые приведены на рисунке. Другие ошибки описаны в руководстве к прибору и элиминируются в процессе работы в рабочем порядке.

Присутствие артефактов затрудняло распознавание истинных пиков. Для корректной интерпретации результатов необходимо считать, что «плюс» пик должен иметь большее числовое значение длины пробега, чем у других пиков. Неоднозначность в определении истинного пика может возникнуть в случае, когда все перечисленные артефракты по вольтажу имеют почти равные значения. Данная картина наблюдалось примерно в
5-10\% используемых маркеров.

При применении микросателлитных локусов не допускается отклонение от референтных значений более чем на 1-2 пар нуклеотидов и выход за референтные интервалы (BINs, biological identification numbers) на генетическом анализаторе. Согласно ISAG/ICAR запрещено смещать выявленные длины микросателлитов, при несовпадении с BIN, ссылаясь на качество капиллярного массива, геля, реагентов или проведённого ПЦР. В данном случае следует искать причину в использовании не рекомендуемых производителем реагентов или протоколов исследования.

В случае генотипирования по SNP применяется стандартная основная (100 локусов) и дополнительная панель (+100 локусов), которая должна полностью соответствовать списку ISAG/ICAR. Taкая панель представлена на всех генетических чипах, разработанных для генотипирования крупного рогатого скота компаниями Illumina [15] и Affimetrix [16]. При проведении генотипирования по SNP допускается ошибка определения не более двух локусов, и ошибка несовпадения при определении родителей не более чем в двух локусах [14].

\section{Выводы}

На основании полученных результатов сделаны следующие выводы:

1) разработан универсальный метод генетической идентификации молочного и мясного скота в соответствии с международными консорциумами животноводов и сертификации ICAR/ISAG;

2) выявлены ошибки первичного учета и результатов генотипирования по микросателлитным участкам генома животных, которые составили до $11 \%$ для молочного и до $25 \%$ для мясного скота в ряде хозяйств Тюменской и Курганской областей, а также ХМАО-Югра;

3) выявлено не менее $88 \%$ совпадений по обоим родителям молочного скота для черно-пестрой породы, до 3\% ошибочных записей в родословной потомков, для голштинской - до $11 \%$ в ряде предприятий Тюменской и Курганской областей, а также ХМАО-Югра;

4) для мясных пород животных величина ошибок по генетической идентификации у абердин-ангусов составила до $10 \%$ и у герефордов до $25 \%$ в ряде предприятий Тюменской и Курганской областей, а также ХМАО-Югра;

5) выявили артефакты в виде дополнительных, а также отсутствие истинных пиков для некоторых локусов при интерпретации электрофореграмм микросателлитных участков генома некоторых пород крупного рогатого скота молочного и мясного направлений продуктивности предприятий Тюменской и Курганской областей, а также ХMАО-Югра. 

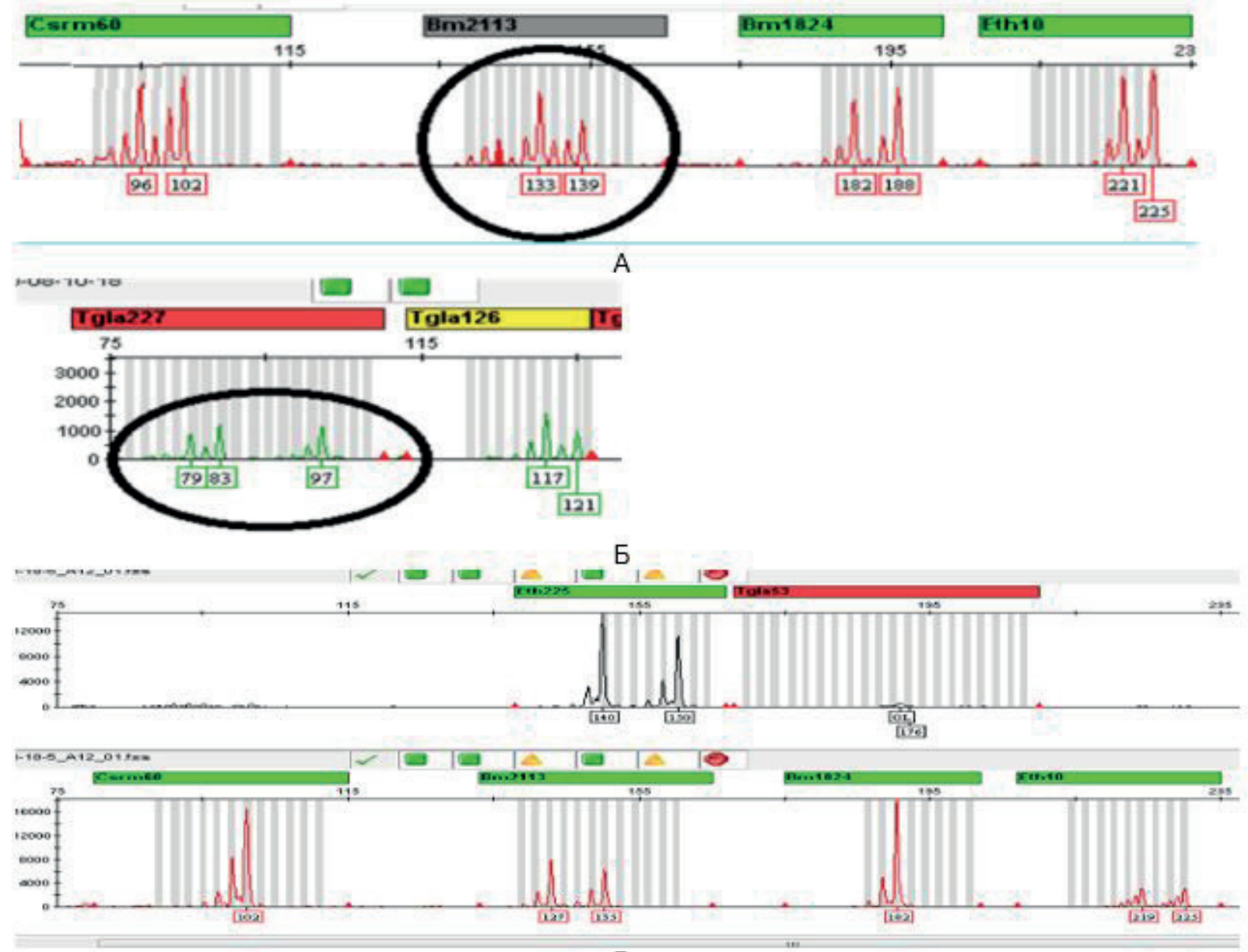

B

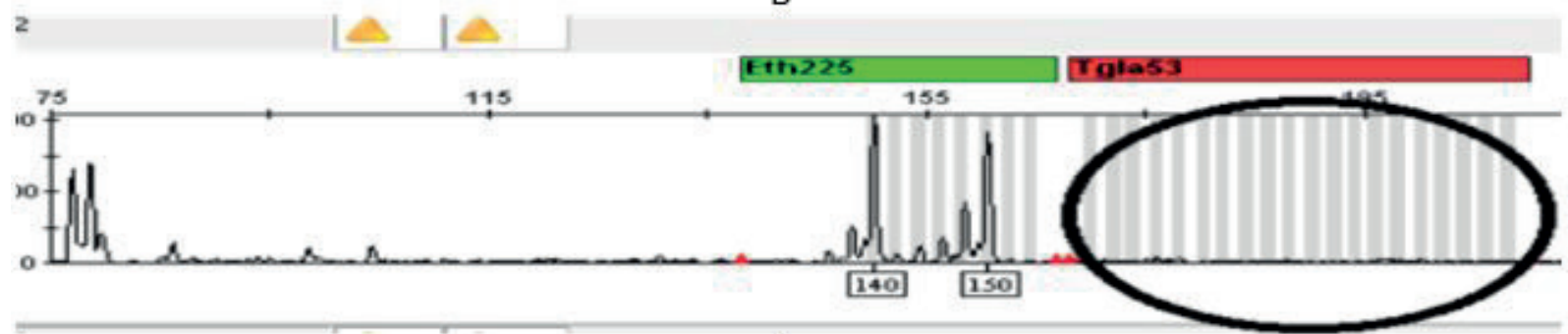

$\Gamma$

Рис. - Электрофореграммы с дополнительным (ложным) пиком (А, Б) либо отсутствием истинного (В, Г)

Работа выполнена в рамках Государственного задания Министерства сельского хозяйства Российской Федерации: №082-03-2018-130 и № 082-03-2019-307 (ААAA-A19-119082890021-3). Генетический материал предоставлен племенными хозяйствами Тюменской и Курганской областей, а также ХМАО-Югра: АО «Приозерное», ООО «Бизон», ООО «Суерь», ЗАО «Падунское», АО «ПЗ «Учхоз ГАУ Северного Зауралья», ООО «Башмаков», ООО «ЗапСибХлебИсеть», ООО «Герефорд».

\section{Список литературы}

1. Бойко, Е.Г. Перспективы использования геномного анализа при разведении и селекции крупного рогатого скота / Е.Г. Бойко // Аграрный вестник Урала. - 2009. - №10(64). - С. 33-34.

2. Глазунов, Ю.В., Кабицкая Я.А., Плотников И.В. Сравнительная оценка методов прижизненной диагностики и эпизоотическая ситуация по лейкозу крупного рогатого скота в Тюменской области / Ю.В. Глазунов, Я.А. Кабицкая, И.В. Плотников // Вестник АПК Ставрополья. - 2017. - №2 (26). - С. 63-68.
3. Зиновьева, Н.А., Гладырь, Е.А., Костюнина, О.В., Харзинова, В.Р., Покровская, М.В. и др. Роль ДНК диагностики в контроле и элиминации рецессивных наследственных аномалий сельскохозяйственных животных / Н.А. Зиновьева, Е.А. Гладырь, О.В. Костюнина, В.Р. Харзинова, М.В. Покровская и др. // Достижения науки и техники в АПК. - 2012. - №11. - С. 37-40.

4. Калашников, А.Е., Калашникова Л.А., Ялуга В.Л., Прожерин В.П. Постгеномная селекция крупного рогатого скота как необходимый этап развития 
успешной экономической модели в России / А.Е. Калашников, Л.А. Калашникова, В.Л. Ялуга, В.П. Прожерин // Главный зоотехник. - 2019. - №5. - С. 3-10.

5. Кузнецов, В.М. Основы научных исследований в животноводстве / В.М. Кузнецов. - Киров: Зональный НИИСХ Северо-Востока, 2006. - 568 с. - ISBN 5-7352-0110-7. - Текст : непосредственный.

6. Новоселов, Н.А. Роль ДНК-технологий в селекции сельскохозяйственных животных Тюменской области / Н.А. Новоселов, Я.А. Кабицкая // Сборник статей международной научно-практической конференции «Интеграция науки и практики для развития Агропромышленного комплекса». - Государственный аграрный университет Северного Зауралья, 2018. - С.21-26. - Библиогр.: с. 292 ( 4 назв.)

7. Тюренкова Е.Н. Еще раз о проблемах племенного учета // Farm Animals. - 2014. - №3 (7). C.30-31.

8. Hobolth A., Siren J. The multivariate WrightFisher process with mutation: Moment-based analysis and inference using a hierarchical Beta model / A. Hobolth, J.Siren // Theor Popul Biology. - 2016. Vol. 108. - P.36-50.

9. Miko, I. Gregor Mendel and the principles of inheritance / I. Miko. - Nature Education, 2008. Vol. 1(1). - P. 134.

10. Primorac, D. Forensic DNA Applications: An Interdisciplinary Perspectiv / D. Primorac, M. Schanfield // - CRC Press, 2014. - P.1-647.

11. Tataru P., Bataillon T., Hobolth A. Inference Under a Wright-Fisher Model Using an Accurate Beta Approximation / P. Tataru, T. Bataillon, A. Hobolth //
Genetics. - 2015. - Vol. 201 (3). - P.1133-1141.

12. Xu L., Haasl R.J., Sun J., Zhou Y., Bickhart D.M., Li J., Liu G.E. Systematic Profiling of Short Tandem Repeats in the Cattle Genome / L. Xu, R.J. Haasl, J. Sun, Y. Zhou, D.M. Bickhart, J. Li, G.E. Liu // Genome Biology Evolution. -2017.-Vol.9(1). -P.20-31.

13. Yao Y., Yang Q., Shao C., Liu B., Zhou Y., Xu H., Zhou Y., Tang Q., Xie J. Null alleles and sequence variations at primer binding sites of STR loci within multiplex typing systems / Y. Yao, Q. Yang, C. Shao, B. Liu, Y. Zhou, H. Xu, Y. Zhou, Q. Tang, J. Xie // Leg Medical (Tokyo). - 2018. - P.10-13.

14. The International Non-Governmental Organization of Animal Recording: официальный сайт компании: сайт. - URL:http://www. icar. org (дата обращения 09.12.2019). - Режим доступа: для зарегистрир. пользователей. - Текст: электронный.

15. The International Society and the International Foundation for Animal Genetics : официальный сайт компании: сайт. - URL:http:/ www. isag. us (дата обращения 09.12.2019). - Режим доступа: для зарегистрир. пользователей. - Текст: электронный.

16. The Illumina Co: официальный компании «Иллюмина»: сайт. - URL: www.illumina.com (дата обращения 09.12.2019). - Режим доступа: для зарегистрир. пользователей. - Текст: электронный.

17. The Thermofisher Co: офрициальный сайт AO «Термо Фишер Сайентифик», Россия: сайт. . URL: http://www.thermofisher.com (дата обращения 09.12.2019). - Режим доступа: для зарегистрир. пользователей. - Текст: электронный.

\title{
GENETIC IDENTIFICATION AS THE CRITERION OF PRIMARY ERRORS BEHIND THE REGISTRATION OF CATTLE ON THE TERRITORY OF THE URALS FEDERAL DISTRICT
}

\begin{abstract}
Kabitskaya Yana A., graduate student, North Ural State Agrarian University (Tyumen), yanakabickaya@ yandex.ru

Kalashnikova Liubov A., habit. Dr., professor, All-Russian Research Institute of Animal Breeding (Ministery of Agriculture RF), lakalashnikova@mail.ru

Boyko Elena G., Ph.D., prof. ass., rector, North Ural State Agrarian University (Tyumen), egboyko@ yandex.ru

Kalashnikov Aleksandr Ye., Ph.D., All-Russian Research Institute of Animal Breeding (Ministry of Agriculture RF), ФГБНУ aekalashnikov@yandex.ru

It is necessary to clarify data on the relationship of cattle progeny in the directions of dairy and meat production by molecular genetic methods and organization of breeding work. To accomplish this task, a comparison of primary registration data on the relationship of animals from the information-analytical system (IAS) was carried out taking into computation the Mendelian inheritance of genotypes from parents to offspring identified using DNA testing. A simple and affordable method for analyzing micro-satellite nuclear DNA loci was used as a definition of genetic relationships. A genetic bank of cattle samples was created and systematized for 4716 animals for research purposes. The extent of incorrect entries in the pedigree of descendants is given according to the primary counting data and the results of genotyping in the panel of 15 micro-satellite loci for animal enterprises of the Tyumen and Kurgan regions, as well as the Khanty-Mansi Autonomous Okrug-Yugra was observed. At least $88 \%$ of the matches were found for both parents of 531 "triples" (mother-offspringfather) animals of the milk cattle. Up to $3 \%$ of incorrect entries in the pedigree of offspring for the black-motley breed and up to $11 \%$ for Holstein were identified for their parents. The genetic identification errors for meat breeds for Aberdeen Angus was achieved in 10\% and Hereford to $25 \%$. It is established that micro-satellites are a tool for determining the accuracy of origin, according to the worldwide quality standard. They are suitable for verifying primary zoo-technical data and genetic identification of dairy and beef cattle.
\end{abstract}

Key words: reliability of origin, microsatellite, genetic identification, accounting errors, registration errors, AgrolS, ISAG, ICAR. 


\section{Literatura}

1. Bojko, E.G. Perspektivy ispol'zovaniya genomnogo analiza pri razvedenii i selekcii krupnogo rogatogo skota / E. G. Bojko // Agrarnyj vestnik Urala. - 2009. - №10(64). - S. 33-34.

2. Glazunov, YU.V., Kabickaya YA.A., Plotnikov I.V. Sravnitel'naya ocenka metodov prizhiznennoj diagnostiki i epizooticheskaya situaciya po lejkozu krupnogo rogatogo skota v Tyumenskoj oblasti / YU.V. Glazunov, YA.A. Kabickaya, I.V. Plotnikov // Vestnik APK Stavropol'ya. - 2017. - №2 (26). - S. 63-68.

3. Zinov'eva, N.A., Gladyr', E.A., Kostyunina, O.V., Harzinova, V.R., Pokrovskaya, M.V. i dr. Rol' DNK diagnostiki $v$ kontrole $i$ eliminacii recessivnyh nasledstvennyh anomalij sel'skohozyajstvennyh zhivotnyh / N.A. Zinov'eva, E.A. Gladyr', O.V. Kostyunina, V.R. Harzinova, M.V. Pokrovskaya i dr. // Dostizheniya nauki i tekhniki v APK. - 2012. - №11. - S. 37-40.

4. Kalashnikov, A.E., Kalashnikova L.A., YAluga V.L., Prozherin V.P. Postgenomnaya selekciya krupnogo rogatogo skota kak neobhodimyj etap razvitiya uspeshnoj ekonomicheskoj modeli v Rossii / A. E. Kalashnikov, L.A. Kalashnikova, V.L. YAluga, V.P. Prozherin // Glavnyj zootekhnik. - 2019. - №5. - S. 3-10.

5. Kuznecov, V.M. Osnovy nauchnyh issledovanij v zhivotnovodstve / V.M. Kuznecov. - Kirov: Zonal'nyj NIISKH Severo-Vostoka, 2006. - 568 s. - ISBN 5-7352-0110-7. - Tekst : neposredstvennyj.

6. Novoselov, N.A. Rol' DNK-tekhnologij v selekcii sel'skohozyajstvennyh zhivotnyh Tyumenskoj oblasti / N.A. Novoselov, YA.A. Kabickaya // Sbornik statej mezhdunarodnoj nauchno-prakticheskoj konferencii "Integraciya nauki i praktiki dlya razvitiya Agropromyshlennogo kompleksa». - Gosudarstvennyj agrarnyj universitet Severnogo Zaural'ya, 2018. - S.21-26. - Bibliogr.: s. 292 ( 4 nazv.)

7. Tyurenkova E.N. Eshche raz o problemah plemennogo ucheta // Farm Animals. - 2014. - №3 (7). S.30-31.

8. Hobolth A., Siren J. The multivariate Wright-Fisher process with mutation: Moment-based analysis and inference using a hierarchical Beta model / A. Hobolth, J.Siren // Theor Popul Biology. - 2016. Vol. 108. P.36-50.

9. Miko, I. Gregor Mendel and the principles of inheritance /I. Miko. - Nature Education, 2008. Vol. 1(1). - P. 134.

10. Primorac, D. Forensic DNA Applications: An Interdisciplinary Perspectiv / D. Primorac, M. Schanfield // - CRC Press, 2014. - P.1-647.

11. Tataru P., Bataillon T., Hobolth A. Inference Under a Wright-Fisher Model Using an Accurate Beta Approximation / P. Tataru, T. Bataillon, A. Hobolth // Genetics. - 2015. - Vol. 201 (3). - P.1133-1141.

12. Xu L., Haas/ R.J., Sun J., Zhou Y., Bickhart D.M., Li J., Liu G.E. Systematic Profiling of Short Tandem Repeats in the Cattle Genome / L. Xu, R.J. Haasl, J. Sun, Y. Zhou, D.M. Bickhart, J. Li, G.E. Liu // Genome Biology Evolution. - 2017. - Vol. 9(1). - P.20-31.

13. Yao Y., Yang Q., Shao C., Liu B., Zhou Y., Xu H., Zhou Y., Tang Q., Xie J. Null alleles and sequence variations at primer binding sites of STR loci within multiplex typing systems /Y. Yao, Q. Yang, C. Shao, B. Liu, Y. Zhou, H. Xu, Y. Zhou, Q. Tang, J. Xie // Leg Medical (Tokyo). - 2018. - P.10-13.

14. The International Non-Governmental Organization of Animal Recordihg: oficial'nyj sajt kompanii: sajt. - URL:http://Www. icar. org (data obrashcheniya 09.12.2019). - Rezhim dostupa: dlya zaregistrir. pol'zovatelej.

- Tekst: elektronnyj.

15. The International Society and the International Foundation for Animal Genetics : oficial'nyj sajt kompanii: sajt. - URL:http:/ www. isag. us (data obrashcheniya 09.12.2019). - Rezhim dostupa: dlya zaregistrir. pol'zovatelej. - Tekst: elektronnyj.

16. The Illumina Co: oficial'nyj kompanii «lllyumina»: sajt. - URL: www.illumina.com (data obrashcheniya 09.12.2019). - Rezhim dostupa: dlya zaregistrir. pol'zovatelej. - Tekst: elektronnyj.

17. The Thermofisher Co: oficial'nyj sajt AO «Termo Fisher Sajentifik», Rossiya: sajt. . - URL: http://www. thermofisher.com (data obrashcheniya 09.12.2019). - Rezhim dostupa: dlya zaregistrir. pol'zovatelej. - Tekst: elektronnyj.

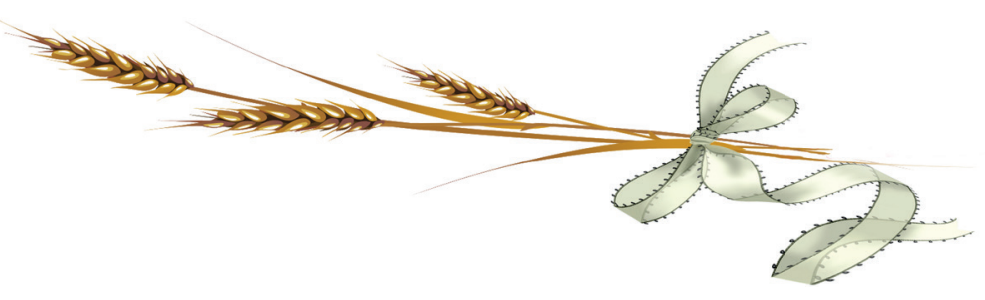


УДК 633.1:631.445.25

DOI 10.36508/RSATU.2020.45.1.021

\section{ДИСКРИМИНАНТНЫЙ АНАЛИЗ В ОЦЕНКЕ УРОЖАЙНОСТИ ЗЕРНОВЫХ КУЛЬТУР НА АГРОСЕРЫХ ПОЧВАХ}

РучкИНА Анастасия Владимировна, аспирант кафедры селекции и семеноводства, агрохимии, лесного дела и экологии, nasni91@gmail.com

УШАКОВ Роман Николаевич, д-р с.-х. наук, профрессор кафредры селекции и семеноводства, агрохимии, лесного дела и экологии, r.ushakov1971@таil.ru

ЕЛИЗАРОВ Андрей Олегович, аспирант кафедры селекции и семеноводства, агрохимии, лесного дела и экологии, Elder-1@уandex.ru

АМЕЛИНА Татьяна Юрьевна, магистрант кафедры селекции и семеноводства, агрохимии, лесного дела и экологии, amelinatania.lovesm@yandex.ru

Рязанский государственный агротехнологический университет имени П.А. Костычева

Цель исследований - методом дискриминантного анализа оченить вклад абиотических (почвенные условия, осадки) и биотических (сорняки) фракторов в формировании урожайности зерновых культур. Урожайность является производной множества условий, проявляющихся в двух результирующих фракторах - климатических и почвенных с подчинением классическим законам земледелия. Реализация продукционного процесса сельскохозяйственных растений, его гомеостатические возможности зависят не только от наличия ресурсов жизнеобеспечения, но и от их доступности для растения. Материальными носителями, обуславливающими доступность ресурсов в почве, являются различные компоненты, которые генерируют разнообразные связи внутри почвы и в фоормате почва - растение. Для достоверной оценки сложных и многообразных явлений, оказывающих влияние на формирование урожайности необходимо применять методы многомерного статистического анализа, в частности, дискриминантный анализ. Минимальное значение продуктивности севооборотов, с экономической точки зрения, не должно составлять ниже 25-30 и з.ед/га. Массив данных по урожайности зерновых культур был разбит на группу 1 (урожайность ниже 25-30 u з. ед/га) и группу 2 (больше 25-30 и з. ед/га). Всего было определено 180 комбинаций. Это стало возможным благодаря многолетнему опыту, заложенному Л.В. Ильиной по комплексному окультуриванию агросерой почвы с внедрением систем удобрений, обработки, севооборотов. Дискриминация между группами была значима. В процедуре дискриминации наиболее желательным является присутствие переменной «Сорняки» (соответствует наибольшее значение Уилкса Лямбда). На данный факт указывает также значение частной лямбды (характеризует единичный вклад), именно переменная "Сорняки» дает наибольший вклад, вторая переменная по значению вклада - «Калий». Ощутимый вклад сорняков обусловлен конкуренцией с их стороны за использование одних и тех же экологических ресурсов, которые необходимы и культурным растениям. За счет более эфрфективной организации экологической ниши сорная растительность снижает потенциал реализации климатических и погодных условий.

Ключевые слова: дискриминантный анализ, урожайность, зерновые культуры, почвенные условия, агросерая почва.

\section{Введение}

Урожайность является производной множества условий, проявляющихся в результирующих двух факторах - климатических и почвенных с подчинением классическим законам земледелия. Выявление лимитирующих условий - достаточно сложная задача, даже при условии использования специальных программных продуктов. Это связано с наличием в почве, как многокомпонентной биокосной открытой системе, разнообразных и разноуровневых почвенных акцепторов и доноров сигналов и энергии, взаимно генерирующие разные по направлениям и природе внутрисистемные связи. Они в еще большей степени усложняются по причине проявления внешних факторов. Для понимания условий формирования урожайности следует упростить подход, допустив, что в основе многообразия связей лежат в том числе и опосредованные отношения, которые в конечном итоге замыкаются на информативных субстантивных структурах, диагностируемых определенным набором незначительно коррелируемых показателей (хотя присутствие корреляций неизбежно). Это показатели, которые отражены в моделях плодородия, при общем приближении - засоренность, гумус, элементы питания, запасы воды, плотность.

В научной литературе представлено достаточно много публикаций, отражающих зависимость урожайности сельскохозяйственных культур от климатических и почвенных условий [1- 9].

Схема и методика проведения исследований

Цель исследований - методом дискриминантного анализа оценить вклад абиотических (почвенные условия, осадки) и биотических (сорняки) факторов в формировании урожайности зерновых культур.

Задачи исследований - оценить вклад гумуса, плотности почвы, запаса воды, азота, фосфрора, калия, сорняков, осадков, а также дискриминацию урожайности зерновых культур (средние значения урожайности озимой пшеницы, ячменя) за 30-летний массив данных.

Материалы и методы исследований. Минимальное значение продуктивности севооборотов, С экономической точки зрения, не должно состав-

() Ручкина А. В., Ушаков Р. Н., Елизаров А. О., Амелина Т. Ю., 2020 г. 
лять ниже 25-30 ц з. ед/га. Для того, чтобы спрогнозировать события превышения и не превышения данного уровня, был применен дискриминантный анализ (D = b0+b1X1+b2X2+....+bkXk), где в роли зависимого от указанных в данной формуле количественно задаваемых параметров был взят качественный параметр - группы: сценарий урожайности больше 25-30 ц з. ед/га (1) и меньше 25-30 ц з. ед/га (0). Во избежание проявления возможной созависимости между количественными параметрами был использован метод их пошагового включения в математическую обработку.

У составленной матрицы менялись показатели всех указанных параметров: количество осадков составляло от 10 мм до 50 мм; содержание гумуса менялось в пределах от 1,7 до 3,0\%; макроэлементов - от низкой обеспеченности до повышенной; общая засоренность многолетними и малолетними сорняками менялась от слабого до высокого уровня. Суммарно было учтено 180 комбинаций. Это стало возможным благодаря многолетнему опыту по комплексному окультуриванию серой лесной почвы с внедрением систем удобрений, севооборотов, обработки почвы.

За 30 лет Л.В. Ильиной был сорормирован и систематизирован большой научный материал по почве и растениям с опыта по методам окультуривания. Данные работы проводились на базе двух севооборотов, застающих во времени шесть ротаций: первый полевой зернопропашной севооборот состоял из последовательного чередования викоовсяной смеси (на сено), озимой пшеницы, картофеля, ячменя и овса; второй севооборот (полевой зернотравянопропашной) включал в себя те же самые культуры, кроме однолетних трав, они были заменены на многолетние - клевером. В данных севооборотах рассматривали системы основной обработки почвы с разной мощностью пахотного слоя и различными методами его углубления (табл. 1).

Схемы обработки почвы заложены на трех фонах: 1) без внесения удобрений (контроль); 2) средние дозировки минеральных и органических удобрений; 3) высокие дозировки минеральных и органических удобрений. Вычисление доз удобрений осуществляли на основании планируемого урожая и содержания в почве элементов питания.

Опыт закладывали методом расщепленных делянок, методом рандомизации выбирались схемы обработки почвы в повторениях. Повторность - четырехкратная. Площадь делянки третьего по-

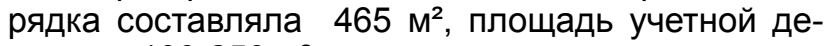
лянки - 100-250 м².

Во всех ротациях севооборотов агротехнические условия возделывания сельскохозяйствен- ных культур были равными и общепринятыми для зоны.

В качестве переменных дискриминантного анализа учтены гумус, плотность, запасы воды, азот, фосфор, калий, сорняки, осадки.

В биомассе сорняков общий азот вычисляли по методу Кьельдаля, общий фосфор - колориметрическим методом, калий - пламенно-фотометрическим методом.

\section{Результаты исследований}

Реализация продукционного процесса сельскохозяйственных растений, его гомеостатические возможности зависят не только от наличия ресурсов жизнеобеспечения, но и от их доступности для растения, эффективности использования. Материальными носителями, обуславливающими доступность ресурсов в почве, являются различные компоненты, которые генерируют разнообразные связи внутри почвы и в фрормате почва - растение. Разобраться со всей сложностью явления формирования урожайности позволяют методы многомерного статистического анализа, в частности дискриминантный анализ. Дискриминантный анализ - это раздел статистики, содержанием которого является разработка методов решения задач различения (дискриминации) объектов наблюдения по определенным признакам.

Внутри агрофитоценоза сорные растения с более широкой дифференциацией экологических ниш в отношении использования почвенных фракторов создают существенную конкуренцию сельскохозяйственным растениям. Сорная растительность если не истощает почву элементами питания, то, потребляя доступный пул азота, фосфрора, калия и т. д., создает условия для мобилизации запасных ресурсов. С точки зрения обеспечения устойчивости системы это не может считаться благоприятным процессом. По химическому составу сорных растений, т.е. содержанию в их биомассе азота, фосфора, калия и других, можно рассчитать вынос элементов питания сорным компонентом агрофитоценоза с учетом его продуктивности и структуры видового состава, т.к. разные виды сорняков потребляют неодинаковое количество элементов. Например, из представленных в таблице 1 растений больше всего азота выносят азот вьюнок полевой, осот полевой, полынь горькая, т.к. в их биомассе содержание азота составило около 30 г/кг. Около 4 г фосфора содержится в 1 кг полыни горькой и куриного проса; чуть больше трех граммов в килограмме осота полевого и мари белой; калий больше всего потребляют марь белая (около 67 г/кг), осот полевой (49 г/кг), полынь горькая (34.9 г/кг), пырей ползучий и куриное просо - около 33 г/кг.

Таблица 1 - Химический состав сорных растений, г/кг

\begin{tabular}{|l|c|c|c|c|c|}
\hline $\begin{array}{c}\text { Сорные } \\
\text { растения }\end{array}$ & Азот & Фосфор & Калий & Кальций & Магний \\
\hline Вьюнок полевой & 32,1 & 2,8 & 19,7 & 10,0 & 6,9 \\
\hline Осот полевой & 30,2 & 3,4 & 49,1 & 22,0 & 9,4 \\
\hline $\begin{array}{l}\text { Черноголовник } \\
\text { обыкновенный }\end{array}$ & 21,0 & 2,5 & 14,7 & 13,6 & 1,4 \\
\hline
\end{tabular}


Продолжение таблицы 1

\begin{tabular}{|l|c|c|c|c|c|}
\hline $\begin{array}{l}\text { Ромашка } \\
\text { непахучая }\end{array}$ & 19,0 & 2,9 & 28,5 & 12,0 & 3,5 \\
\hline $\begin{array}{l}\text { Одуванчик } \\
\text { лекарственный }\end{array}$ & 25,4 & 2,5 & 30,9 & 22,4 & 8,5 \\
\hline Костер ржаной & 21,7 & 2,8 & 20,8 & 4,8 & 1,7 \\
\hline Василек синий & 16,5 & 2,5 & 15,3 & 11,8 & 4,6 \\
\hline Хвощ полевой & 19,6 & 2,0 & 11,6 & 29,0 & 6,1 \\
\hline Полынь горькая & 31,1 & 4,5 & 34,9 & 11,6 & 3,1 \\
\hline Куриное просо & 20,9 & 4,2 & 33,5 & 5,6 & 5,6 \\
\hline Бодяк полевой & 26,7 & 2,4 & 17,7 & 28,4 & 8,0 \\
\hline Пырей ползучий & 21,5 & 2,1 & 33,4 & 3,2 & 1,8 \\
\hline $\begin{array}{l}\text { Молочай } \\
\text { прутьевидный }\end{array}$ & 21,2 & 2,8 & 12,8 & 13,6 & 2,9 \\
\hline Марь белая & 24,8 & 3,5 & 67,4 & 18,4 & 15,3 \\
\hline
\end{tabular}

Вынос элементов питания сорняками может составлять 5-20\% от общего выноса их культурной растительностью, что не может не отразиться на потенциале устойчивости почвы по агрохимическому градиенту.

Сорная растительность использует те же факторы жизни, что и культурная. Для определения вклада сорной растительности в снижение продуктивности севооборота нами на основе научных данных, полученных Л.В. Ильиной (1987) в многолетнем полевом опыте с минеральными и органическими удобрениями, переменная "Сорняки" была включена в дискриминантный анализ.

В таблице 2 показаны средние значения переменных. Расчет коэффрициентов корреляции не показал наличие тесных зависимостей между большинством переменных за исключением азо- та и фосфора. Содержание азота и фосфора не прошли нижнюю границу толерантности (1-R2 < 0,01), поэтому они признаны неинформативными (избыточными). При конкретном массиве данных показатели создают сильную внутригрупповую изменчивость (коэффрициент корреляции $r$ около 1, табл. 3). Поэтому переменные, к сожалению, были исключены из обработки. Их вынужденная выбраковка снижает ценность проводимого анализа, делает невозможной более широкую интерпретацию результатов. Отчасти невключение в модель азота объясняется тем, что он представлен расчетным путем через содержание гумуса. В корреляционных матрицах отмечается тесная связь между фосфором и калием, что связано с количественной синхронностью при применении фоосфорных и калийных удобрений.

Таблица 2 - Средние значения переменных

\begin{tabular}{|c|c|c|c|c|c|c|c|c|}
\hline Условия & $\begin{array}{c}\text { Гумус, } \\
\%\end{array}$ & 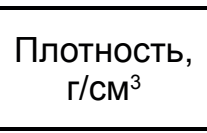 & $\begin{array}{c}\text { Запасы } \\
\text { воды, } \\
\text { мМ }\end{array}$ & $\begin{array}{l}\text { Азот, } \\
\text { мг/кг }\end{array}$ & $\begin{array}{l}\text { Фосфрор, } \\
\text { мг/кг }\end{array}$ & $\begin{array}{l}\text { Калий, } \\
\text { мг/кг }\end{array}$ & $\begin{array}{c}\text { Сорняки, } \\
\text { шт/ } \text { м }^{2}\end{array}$ & $\begin{array}{c}\text { Осадки, } \\
\text { мм }\end{array}$ \\
\hline $\begin{array}{c}\text { Группа } 1 \\
<30 \text { ц з. ед./га }\end{array}$ & 2,3 & 1,15 & 97,0 & 13,2 & 9,5 & 11,3 & 80,5 & 29,4 \\
\hline $\begin{array}{c}\text { Группа } 2 \\
>30 \text { ц з. ед./га }\end{array}$ & 2,5 & 1,16 & 100,4 & 19,4 & 14,6 & 16,3 & 26,9 & 36,6 \\
\hline Общая & 2,38 & 1,15 & 98,3 & 15,6 & 11,5 & 13,2 & 60,0 & 32,22 \\
\hline
\end{tabular}

Остальные переменные нелинейно независимы, значит, мультиколлинеарность отсутствует. Выбранные фракторы не понижают качество модели (табл. 3).

Таблица 3 - Корреляционная матрица

\begin{tabular}{|c|c|c|c|c|c|c|c|c|}
\hline & $\begin{array}{c}\text { Гумус, } \\
\%\end{array}$ & $\begin{array}{c}\text { Плот- } \\
\text { ность, г/ } \\
\text { см }^{3}\end{array}$ & $\begin{array}{c}\text { Запасы } \\
\text { воды,мм }\end{array}$ & $\begin{array}{l}\text { Азот, } \\
\mathrm{Mr} / 100 \text { г }\end{array}$ & $\begin{array}{l}\text { Фосфpop, } \\
\text { мг/100 г }\end{array}$ & $\begin{array}{l}\text { Калий, } \\
\text { мг/100 г }\end{array}$ & $\begin{array}{l}\text { Сорняки, } \\
\text { шт/M² }\end{array}$ & $\begin{array}{c}\text { Осадки, } \\
\text { мм }\end{array}$ \\
\hline \multirow{2}{*}{ Гумус, \% } & \multicolumn{8}{|c|}{ Внутригрупповая корреляция } \\
\hline & 1 & $-0,04$ & \multirow[b]{2}{*}{0,01} & \multirow[b]{2}{*}{$-0,04$} & \multirow[b]{2}{*}{$-0,04$} & \multirow[b]{2}{*}{$-0,05$} & \multirow[b]{2}{*}{0,18} & \multirow[b]{2}{*}{0,03} \\
\hline $\begin{array}{l}\text { Плотность, } \\
\text { г/см }^{3}\end{array}$ & $-0,03$ & 1 & & & & & & \\
\hline Запасы воды,мм & 0,02 & $-0,43$ & 1 & $-0,02$ & $-0,02$ & $-0,02$ & 0,07 & 0,01 \\
\hline $\begin{array}{l}\text { Азот, } \\
\text { Mг/100 г }\end{array}$ & 0 & 0 & 0 & 1 & 0,99 & 0,99 & 0,30 & $-0,06$ \\
\hline $\begin{array}{l}\text { Фосфpop, } \\
\text { мг/100 г }\end{array}$ & 0 & 0 & 0 & 0,99 & 1 & 1,0 & 0,28 & $-0,06$ \\
\hline
\end{tabular}


Продолжение таблицы 3

\begin{tabular}{|l|c|c|c|c|c|c|c|c|}
\hline $\begin{array}{l}\text { Калий, } \\
\text { мг/100 }\end{array}$ & 0 & 0 & 0 & 0,99 & 1,0 & $\mathbf{1}$ & 0,30 & $-0,06$ \\
\hline Сорняки, шт/м ${ }^{2}$ & 0,06 & $-0,12$ & 0,02 & 0 & 0 & $\mathbf{0}$ & 1 & 0,15 \\
\hline Осадки, мм & 0,05 & 0,06 & 0,02 & 0 & 0 & 0 & 0 & $\mathbf{1}$ \\
\hline
\end{tabular}

Для определения вклада переменных в разделение продуктивности культур на группы использован метод пошаговой дискриминации с включением. Значение общей Уилкса лямбды (до включения переменных в обработку) составило 0,4, F (5,17) - 50,1 при p< 0,01 (табл. 4). Поэтому дискриминация между группами значима. Теперь обратим внимание на независимые вклады каждой отдельной переменной в модели в предсказание. Присутствие переменной "Сорняки" в процедуре дискриминации является наиболее желательным (соответствует наибольшее значение Уилкса лямбда). На это указывает также значение частной лямбды (характеризует единичный вклад), т.е. именно переменная "Сорняки» дает наибольший вклад, вторая переменная по значению вклада «Калий». Переменная "Запасы воды” добавляет в общую дискриминацию меньше всех, к тому же достоверность участия данной переменной статистически не подтверждается ( $p>0,05)$.

По данным из таблицы 4 можно заметить, что значения толерантности всех показателей довольно большие, следовательно, можно сделать вывод об их успешном включении в модель.

Таблица 4 - Список информативных переменных

\begin{tabular}{|l|c|c|c|c|c|}
\hline \multicolumn{1}{|c|}{ Переменная } & $\begin{array}{c}\text { Уилкса } \\
\text { Лямбда }\end{array}$ & $\begin{array}{c}\text { Частная } \\
\text { Лямбда }\end{array}$ & $\begin{array}{c}\text { Значение } \\
\text { F - критерия }\end{array}$ & $\begin{array}{c}\text { Уровень } \\
\text { значимости }\end{array}$ & $\begin{array}{c}\text { Толерантность } \\
\text { 1-R }\end{array}$ \\
\hline Сорняки, шт/м² & 0,84 & 0,48 & 186,0 & $<0,01$ & 0,83 \\
\hline Калий, мг/100г & 0,52 & 0,78 & 47,1 & $<0,01$ & 0,88 \\
\hline Осадки, мм & 0,43 & 0,93 & 11,9 & $<0,01$ & 0,96 \\
\hline Гумус, \% & 0,43 & 0,94 & 10,2 & $<0,01$ & 0,95 \\
\hline $\begin{array}{l}\text { Запасы воды, } \\
\text { мм }\end{array}$ & 0,41 & 0,99 & 1,32 & 0,05 & 0,99 \\
\hline
\end{tabular}

В таблице 5 приведена функция классификации, позволяющий сделать прогноз в отношении продуктивности севооборота.

Таблица 5 - Функция классификаци

\begin{tabular}{|c|c|c|}
\hline Переменная & $\begin{array}{c}\text { Группа } 1 \\
(<30 \text { ц з.ед.)p =0,6 }\end{array}$ & $\begin{array}{c}\text { Группа } 2 \\
(>30 \text { ц з. ед.)p = 0,4 }\end{array}$ \\
\hline Сорняки, шт/м² & 0,037 & $-0,044$ \\
\hline Калий, мг/100 г & 0,225 & 0,45 \\
\hline Осадки, мм & 0,065 & 0,107 \\
\hline Запасы воды, мм & 0,088 & 0,097 \\
\hline Константа & $-14,56$ & $-18,84$ \\
\hline Гумус, \% & 5,203 & 6,397 \\
\hline
\end{tabular}

С целью получения дальнейших результатов и функция. Так как уровень значимости $p<0,05$, кавыяснения природы дискриминации был выпол- нонический корень функции является статистиченен канонический анализ. Чтобы оценить влияние ски значимым. Как видно из таблицы 6, процесс пяти переменных на разделение различных со- разделения на группы прошёл успешно вокупностей, была определена дискриминантная

Таблица 6 - Проверка статистической значимости дискриминантной фрункции

\begin{tabular}{|c|c|c|c|c|c|}
\hline $\begin{array}{c}\text { Корень } \\
\text { функции }\end{array}$ & $\begin{array}{c}\text { Собственное } \\
\text { значение }\end{array}$ & $\begin{array}{c}\text { Собственное } \\
\text { значение }\end{array}$ & $\begin{array}{c}\text { Уилкса } \\
\text { Лямбда }\end{array}$ & Хи-квадрат & $\begin{array}{c}\text { Уровень } \\
\text { значимости }\end{array}$ \\
\hline 1 & 1,3 & 0,75 & 0,43 & 147 & $<0,01$ \\
\hline
\end{tabular}

Далее были рассчитаны стандартизованные коэффрициенты дискриминантных фрункций, которые характеризуют направление и вклад переменных. Как видно из таблицы 7, в дискриминантную функцию наибольший вклад внесен сорной

растительностью, далее калием, осадками и гумусом. Сорняки - более важный признак для дискриминации. Функция ответственна за $100 \%$ объясненной дисперсии. 
Таблица 7 - Стандартизированные коэффициенты для канонических переменных

\begin{tabular}{|l|c|}
\hline Сорняки & $-1,02072$ \\
\hline Калий & 0,63730 \\
\hline Осадки & 0,33518 \\
\hline Гумус & 0,31315 \\
\hline Запасы воды & 0,11298 \\
\hline Собственное значение & 1,45576 \\
\hline Кумулятивный процент & 1,00000 \\
\hline
\end{tabular}

\section{Заключение}

Предложенные дискриминантные функции не являются идеальными, так как не учитывают целый ряд переменных (осадков, азота, фосфора и др.), влияние которых на продуктивность сельскохозяйственных растений очевидно. Результаты классификационных матриц, канонического анализа, расчетов различных коэффициентов не отражают в полной мере интегрального проявления условий группировки, поэтому к ним необходимо относиться с осторожностью. Тем не менее, данный дискриминантный анализ указывает на вклад факторов в фрормирование урожайности зерна.

Присутствие переменной “Сорняки” в процедуре дискриминации является наиболее желательным (соответствует наибольшее значение Уилкса Лямбда). На это указывает также значение частной лямбды (характеризует единичный вклад), т.е. переменная "Сорняки” дает наибольший вклад.

По-видимому, весомый вклад сорняков обусловлен конкуренцией с их стороны за использование одних и тех же экологических ресурсов, которые необходимы и культурным растениям. За счет более эффективной организации экологической ниши сорная растительность снижает потенциал реализации климатических и погодных условий.

\section{Список литературы}

1. Бакаева, Н.П. Влияние погодных условий, систем обработки почвы и удобрений на структуру урожая и качество зерна яровой пшеницы / Н.П. Бакаева // Известия Самарской государственной сельскохозяйственной академии. - 2019. - №4. C. 12-19.

2. Горянин, О.И. Возделывание полевых куль- тур в Среднем Поволжье / О.И. Горянин // Самарский Научно-исследовательский институт сельского хозяйства. Самара. - 2019.

3. Горянин, О.И. Поддержим плодородие пашни / О.И. Горянин, А.П. Чичкин, Б.Ж. Джангабаев // Агро-Информ. - 2017. - №5 (223). - С. 19-20.

4. Куликова, А.Х. Влияние соломы и сидерата на баланс элементов питания в черноземе типичном Среднего Поволжья / А.Х. Куликова. Е.А. Яшин, А.Е. Яшин // Вестник Ульяновской государственной сельскохозяйственной академии. -2019. - № 2 (46). - С. 79-84.

5. Постников, П.А. Урожайность яровой пшеницы в зависимости от погодных условий и фона питания / П.А. Постников // В сборнике: Итоги выполнения программы фундаментальных научных исследований государственных академий на 2013-2020 гг. Материалы Всероссийского координационного совещания научных учрежденийучастников Географической сети опытов с удобрениями. Под ред. акад. РАН В.Г. Сычева. - 2018. - C. 225-230.

6. Сорокина, И.Ю. Влияние погодных условий на урожайность и качество зерна озимой пшеницы / И.Ю. Сорокина, А.В. Кирин // В сборнике: Перспективные этапы развития научных исследований: теория и практика сборник материалов II Международной научно-практической конференции. - 2019. - С. 137-140.

7. Турьянский, А.В. Влияние погодных условий на урожайность зерновых культур // А.В. Турьянский, Н.Р. Асыка, С.И. Смуров [и др.] // Органическое сельское хозяйство: проблемы и перспективы Материалы XXII международной научно-производственной конференции. - 2018. - С. 9-13.

8. Черкасов, Е.А. Динамика агрохимических показателей плодородия черноземов Ульяновской области за 2000-2015 гг. / Е.А. Черкасов, А.Х. Куликова // Почвоведение -продовольственной и экологической безопасности страны тезисы докладов VII съезда Общества почвоведов им. В.В. Докучаева и Всероссийской с международным участием научной конференции. - 2016. - С. 135-136.

9. Шарапов, И.И. Влияние засоренности посевов на урожайность зерна пшеницы в лесостепи Самарской области / И.И. Шарапов // Известия Самарской государственной сельскохозяйственной академии. - 2016. - №1. - С. 61-64.

\section{DISCRIMINANT ANALYSIS IN THE ASSESSMENT OF CROP YIELDS ON AGRIBUSINESS SOILS}

Ruchkina Anastasia V., aspirant of the department of selection and seed production, agrochemistry, forestry and ecology, nasni91@gmail.com

Ushakov Roman N., doctor of agricultural sciences, professor of the department of selection and seed production, agrochemistry, forestry and ecology, r.ushakov1971@mail.ru

Elizarov Andrey O., aspirant of the department of selection and seed production, agrochemistry, forestry and ecology, Elder-1@yandex.ru

Amelina Tatyana Y., magister of the department of Selection and Seed Production, Agrochemistry, Forestry and Ecology, amelinatania.lovesm@yandex.ru

Ryazan State Agrotechnological University named after P.A. Kostycheva

The aim of the studies is to assess the contribution of abiotic (soil conditions, precipitation) and biotic (weed) factors in the formation of crop yields by discriminatory analysis. Yield is a derivative of the many conditions evident in the resulting two factors - climatic and soil with submission to the classical laws of farming. The 
realization of the production process of agricultural plants, its homeostatic capabilities depend not only on the availability of life support resources, but also on their availability for the plant. The material carriers that make resources available in the soil are various components that generate a variety of connections within the soil and in soil-plant format. The methods of multidimensional statistical analysis, in particular discriminant analysis, allow to understand at least all the complexity of the phenomenon of yield formation. From an economic point of view, the minimum productivity of crop rotation should not be lower than $30 \mathrm{c} \mathrm{z}$. piece/ hectare. The crop yield data array was divided into group 0 (yield below 25-30 c z. Unit/ha) and group 1 (more than 25-30 c z. piece/hectare). A total of 180 combinations were determined. This was made possible by the long-term experience laid down by L. V. Ilina on the complex culturing of grey forest soil with the introduction of fertilizer systems, treatment, crop rotation. Discrimination between groups was significant. The presence of the Weeds variable in the discrimination procedure is most desirable (corresponding to Wilkes lambda 's greatest value). This is also indicated by the value of the private lambda (characterizes the unit contribution), i.e. the variable "Weeds" gives the contribution more than all, the variable. "Potassium" is the second most important contribution. The significant contribution of weeds seems to be due to competition on their part for the use of the same environmental resources as cultural plants. Due to more efficient organization of ecological niche, weed vegetation reduces the potential for realization of climatic and weather conditions.

Key words: discriminant analysis, yield, grain crops, soil conditions, agricultural soil.

\section{Literatura}

1. Bakaeva, N.P. Vliyanie pogodnyh uslovij, sistem obrabotki pochvy i udobrenij na strukturu urozhaya $i$ kachestvo zerna yarovoj pshenicy/N.P. Bakaeva//Izvestiya Samarskoj gosudarstvennoj sel'skohozyajstvennoj akademii. - 2019. - №4. - S. 12-19.

2. Goryanin, O.I. Vozdelyvanie polevyh kul'turv Srednem Povolzh'e / O.I. Goryanin // Samarskij Nauchnoissledovatel'skij institut sel'skogo hozyajstva. Samara. - 2019.

3. Goryanin, O.I. Podderzhim plodorodie pashni / O.I. Goryanin, A.P. CHichkin, B.ZH. Dzhangabaev // Agro-Inform. - 2017. - №5 (223). - S. 19-20.

4. Kulikova, A.H. Vliyanie solomy $i$ siderata na balans elementov pitaniya $v$ chernozeme tipichnom Srednego Povolzh'ya / A.H. Kulikova. E.A. YAshin, A.E. YAshin // Vestnik Ul'yanovskoj gosudarstvennoj sel'skohozyajstvennoj akademii. - 2019. - № 2 (46). - S. 79-84.

5. Postnikov, P.A. Urozhajnost' yarovoj pshenicy $v$ zavisimosti ot pogodnyh uslovij $i$ fona pitaniya / P.A. Postnikov // V sbornike: Itogi vypolneniya programmy fundamental'nyh nauchnyh issledovanij gosudarstvennyh akademij na 2013-2020 gg. Materialy Vserossijskogo koordinacionnogo soveshchaniya nauchnyh uchrezhdenij-uchastnikov Geograficheskoj seti opytov s udobreniyami. Pod red. akad. RAN V.G. Sycheva. - 2018. - S. 225-230.

6. Sorokina, I.YU. Vliyanie pogodnyh uslovij na urozhajnost' i kachestvo zerna ozimoj pshenicy / I.YU. Sorokina, A.V. Kirin // V sbornike: Perspektivnye etapy razvitiya nauchnyh issledovanij: teoriya $i$ praktika sbornik materialov II Mezhdunarodnoj nauchno-prakticheskoj konferencii. - 2019. - S. 137-140.

7. Tur'yanskij, A.V. Vliyanie pogodnyh uslovij na urozhajnost' zernovyh kul'tur // A.V. Tur'yanskij, N.R. Asyka, S.I. Smurov [i dr.] // Organicheskoe sel'skoe hozyajstvo: problemy i perspektivy Materialy XXII mezhdunarodnoj nauchno-proizvodstvennoj konferencii. - 2018. - S. 9-13.

8. CHerkasov, E.A. Dinamika agrohimicheskih pokazatelej plodorodiya chernozemov Ul'yanovskoj oblasti za 2000-2015 gg. / E.A. CHerkasov, A.H. Kulikova // Pochvovedenie -prodovol'stvennoj i ekologicheskoj bezopasnosti strany tezisy dokladov VII s"ezda Obshchestva pochvovedov im. V.V. Dokuchaeva i Vserossijskoj s mezhdunarodnym uchastiem nauchnoj konferencii. - 2016. - S. 135-136.

9. SHarapov, I.I. Vliyanie zasorennosti posevov na urozhajnost' zerna pshenicy v lesostepi Samarskoj oblasti / I.I. SHarapov // Izvestiya Samarskoj gosudarstvennoj sel'skohozyajstvennoj akademii. - 2016 . - №1. - S. 61-64.

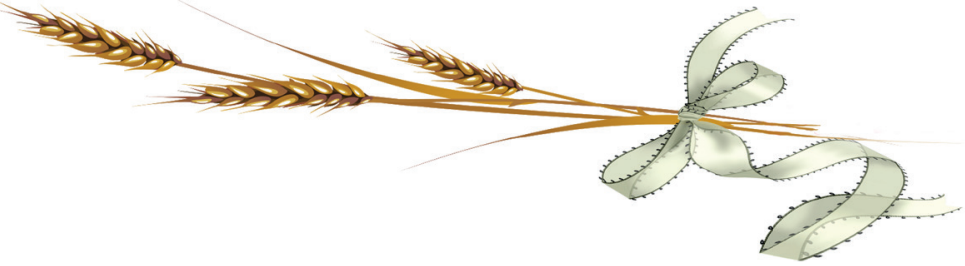




\section{МАЛЮГИН СЕРГЕЙ ГЕРАСИМОВИЧ}

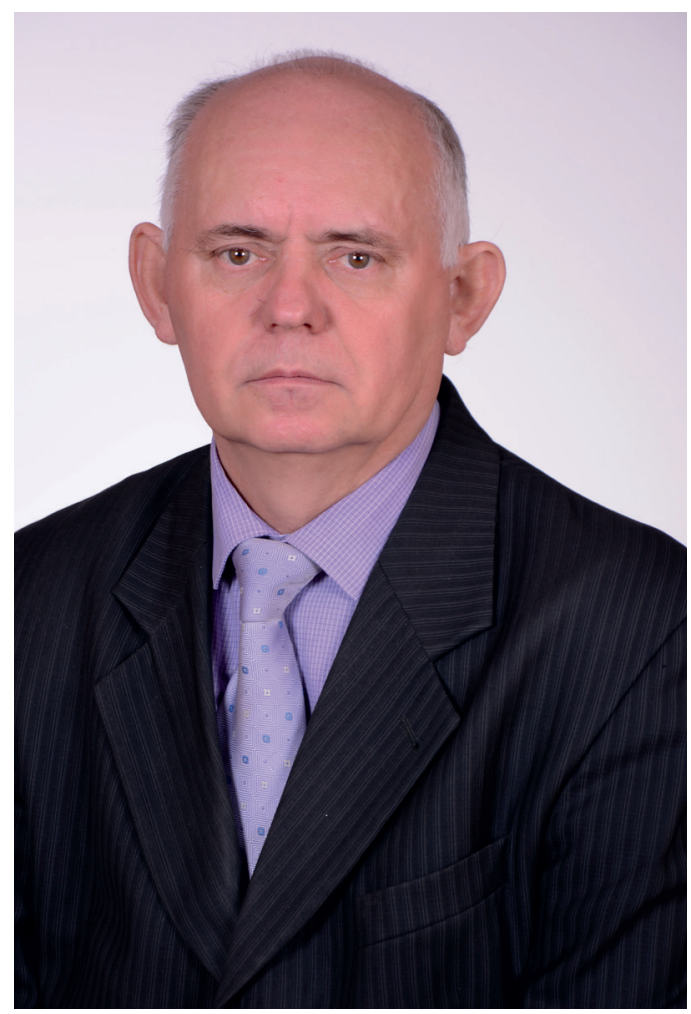

3 января 2020 года отметил свой 70-летний юбилей кандидат технических наук, дочент кафредры “Строительство инженерных сооружений и механика» Малюгин Сергей Герасимович. В 1971 году он поступил в Рязанский сельскохозяйственный институт на фракультет механизации сельского хозяйства, имея за плечами немалый жизненный опыт и трудовой стаж: прохождение службы в ПВО вооруженных сил СА СССР, работу слесарем на заводе. Видимо, поэтому выбор окончательной профессии инженера-механика был обдуманным и серьёзным. На данный момент трудовой стаж Малюгина Сергея Герасимовича составляет 44 года, из них в университете работает Сергей Герасимович - 24 года. C 2007 по 2013 год он возглавлял кафредру «Автомобильные дороги и гидравлика». После объединения двух кафредр «Автомобильные дороги и гидравлика» и "Теоретическая и прикладная механика» под общим названием

«Cтроительство инженерных сооружений и механика» с сентября 2013 года и по настоящее время работает на кафедре в должности доцента. Имеет государственные награды.

Сергей Герасимович постоянно совершенствует своё профрессиональное мастерство, получает новые знания и опыт. Своей профрессиональной деятельностью Малюгин С.Г. содействует росту престижа университета как признанного центра науки, образования и культуры. Его интерес к работе, жизнелюбие, творческий подход к обязанностям и справедливое отношение к окружающим служат примером для коллег. Нельзя не отметить его многолетнюю плодотворную работу по развитию и совершенствованию учебного процесса, значительный вклад в дело подготовки квалифицированных специалистов. Многие поколения студентов и выпускников помнят его отзывчивость и доброту.

Коллектив кафедры «Строительство инженерных сооружений и механика» и автодорожного фракультета от всей души поздравляет Сергея Герасимовича с юбилеем, желает успехов, крепкого здоровья, благополучия и новых научных достижений. 


\section{ТЕКУЧЕВ ВЛАДИМИР ВАСИЛЬЕВИЧ}

Текучев Владимир Васильевич - доктор экономических наук, профессор, почетный работник высшего профрессионального образования Российской Федерации.

Владимир Васильевич родился 28 января 1950 года в рабочем поселке Тульский Майкопского района Краснодарского края, в семье служащих. В 1967 году он окончил с золотой медалью среднюю школу №1 и затем поступил в Рязанский радиотехнический институт, где успешно обучался по специальности «Электронные вычислительные машины». По окончании вуза с 1972 по 1974 год работал инженером кафредры ЭВМ Рязанского радиотехнического института.

Нашему университету Владимир Васильевич посвятил более сорока пяти лет, лучшие годы жизни. Этот путь он начинал в 1974 году ассистентом кафредры экономической кибернетики, затем с 1978 года работал старшим преподавателем. Окончив заочно аспирантуру, в 1982 году защитил

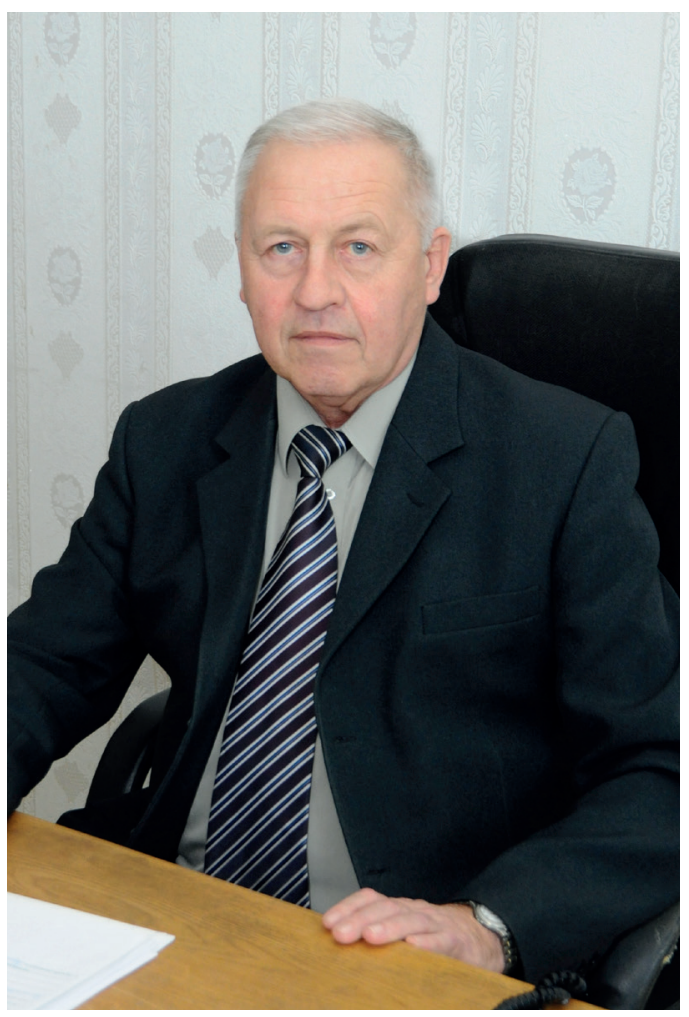
кандидатскую диссертацию, ему была присвоена ученая степень кандидата экономических наук. С 1989 года становится доцентом кафедры, а с 1990 года - бессменным ее руководителем. Должность профрессора он получает в 1995 году. В 1999 году защитил докторскую диссертацию и получил степень доктора экономических наук.

За свой труд награжден званием "Почетный работник высшего профрессионального образования Российской Федерации", награжден почетными грамотами администрации Рязанской области, Рязанской областной Думы.

За время своей профессиональной деятельности подготовил около восьмидесяти научных публикаций, три научные монографии.

Владимир Васильевич - замечательный наставник, под его руководством целая плеяда молодых ученых успешно защитили кандидатские диссертации.

Все, кто работал и работает с ним в одном коллективе, могут сказать $в$ его адрес только добрые и теплые слова благодарности. Это широкой души человек, грамотный управленец, тактичный и порядочный коллега. Руководя кафредрой, он создал благоприятные условия для фрормирования дружного и сплоченного коллектива, атмосферу взачмовыручки и доверия, что способствовало плодотворной работе и достижению поставленных целей.

Администрация университета, коллектив сотрудников и студентов, редакция журнала сердечно поздравляют Вас, Владимир Васильевич, с юбилеем и желают Вам крепкого здоровья, семейного благополучия, оптимизма, неиссякаемой творческой энергии, способных студентов и перспективных аспирантов. 


\section{ЖУЛЕВА НИНА МИХАЙЛОВНА}

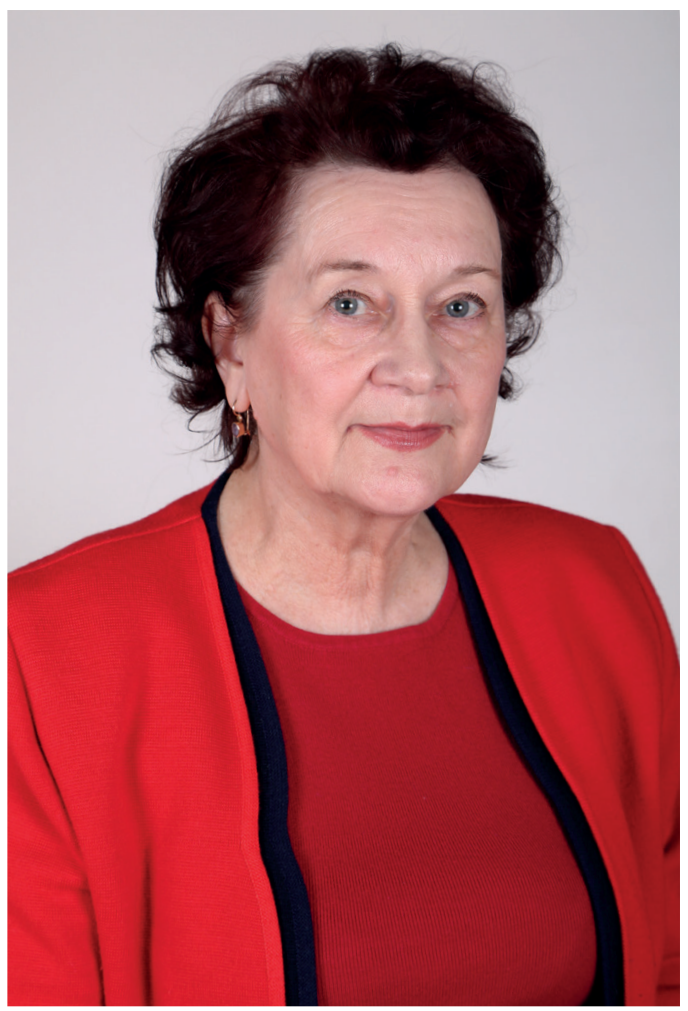

31 марта 2020 г. отметила свой юбилей кандидат исторических наук, доцент кафредры гуманитарных дисциплин Нина Михайловна Жулева. В нашем университете работаem 34 года. За эти годы ею накоплен богатый научный и педагогический потенциал. Она является настоящим экспертом в области истории. Нина Михайловна совместила в себе качества востребованного ученого и глубоко образованного, воспитанного, мудрого преподавателя. В течение 34 лет педагогической работы в Рязанском государственном агротехнологическом университете имени П. А. Костычева вначале в качестве ассистента, затем старшего преподавателя, доцента Нина Михайловна передает свои теоретические и практические знания студентам, являясь примером для молодого поколения. Коллектив кафедры, сотрудники университета, студенты отмечают высокий уровень ее знаний, умение выдвигать новые идеи и эфрфективно

решать исследовательские задачи. Ее лекционные и практические занятия всегда вызывают больщой интерес у обучающихся, поскольку носят инновационный характер и всегда наполнены современным материалом. Нельзя не отметить высокие человеческие качества Нины Михайловны - ее порядочность, человечность, понимание сложившейся ситуации и выход из нее с оптимальным и правильным решением. Хочется отметить активную жизненную позицию этого человека, который всегда придет на помощь, поддержит словом и делом всех, кому это жизненно необходимо. Все, кто знает Нину Михайловну, отмечают ее искренность, порядочность, принципиальность и доброту. Окружающие отмечают её отзывчивость, дружелюбие, позитивный настрой и оптимизм.

Коллектив кафедры гуманитарных дисциплин, сотрудники университета поздравляют с днём рождения замечательного человека. Om всей души желают неутомимых сил и больщого энтузиазма, великих достижений и значительных успехов, почёта и уважения, всеобщего признания и перспективных предложений, жизненной энергии и бодрости, счастья и крепкого здоровья.

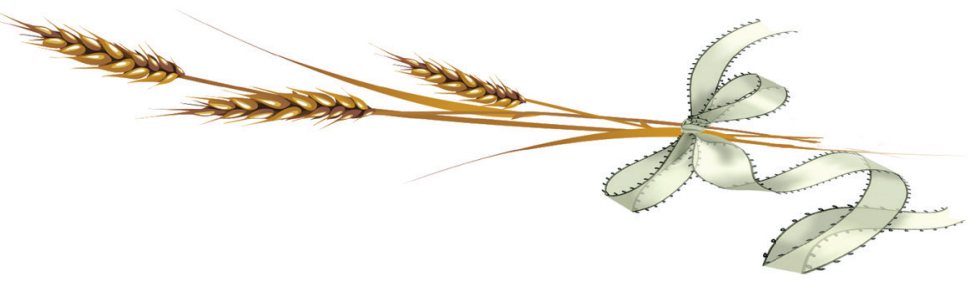




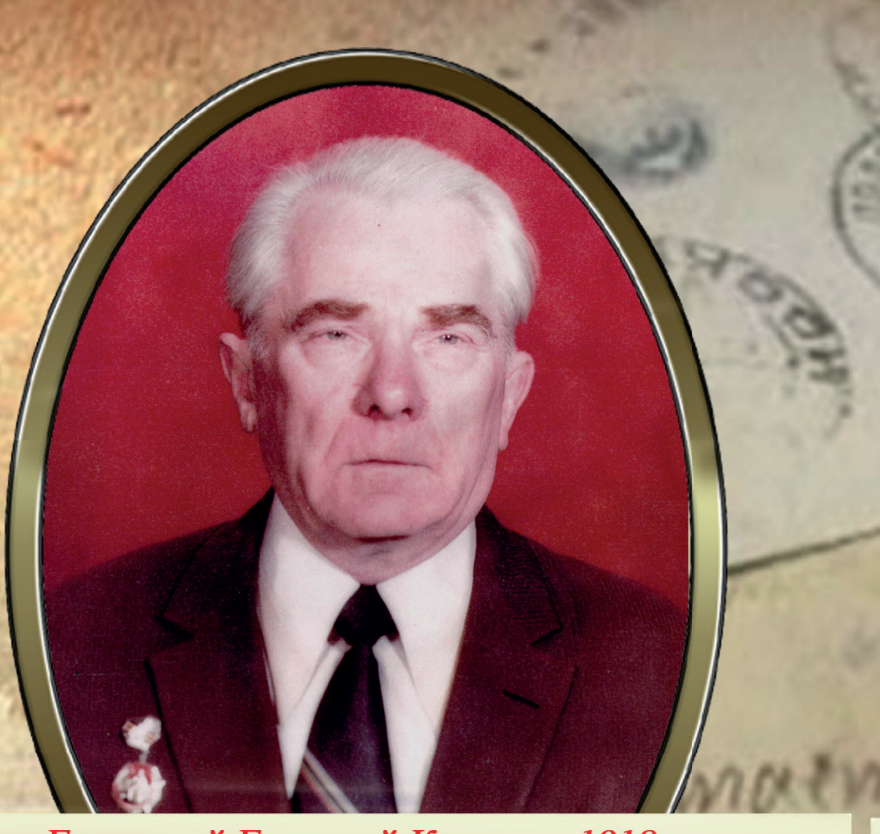

Гудовский Григорий Кузьмич, 1918 г.р., старпий лаборант кафедры физвоспитания. Воевал в составе Дальневосточного фронта в должностях командира роты, начальника оперотдела, помощника начальника отдела

боевой подготовки армии.Воинское звание-полковник.

Награжден 10 правительственными наградамн, в том числе 2 орденами Красной Звезды,

орденом Красного Знамени, медалью “ За боевые заслуги». Ветеран труда.

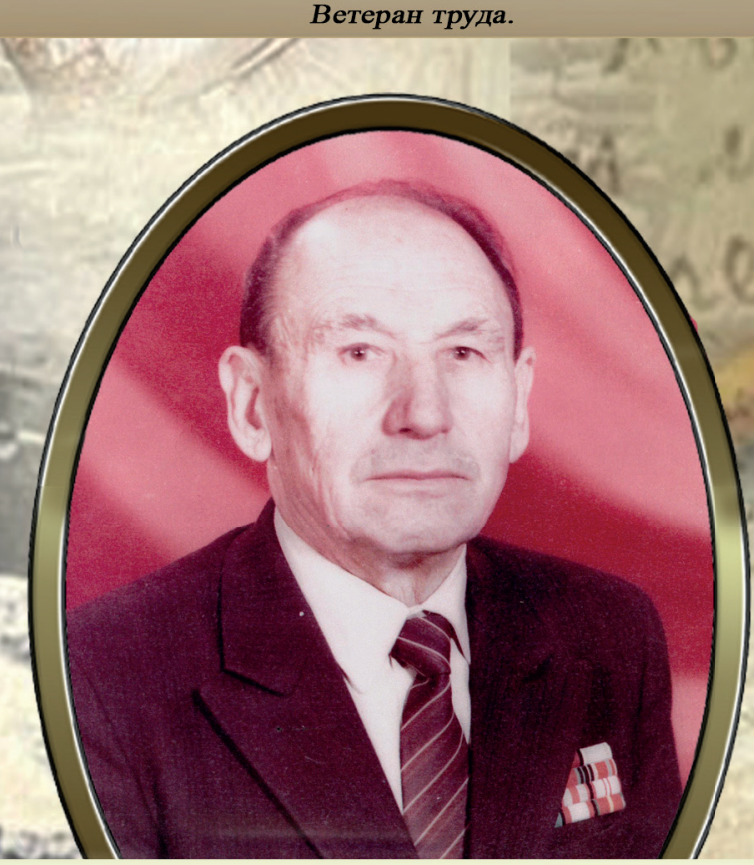

Казак Мирон Федотьевич, 1916 г.р., начальник цикла ГО. Воевал в составе

Юго-Западного фронта, командир пулеметного взвода. Имеет ранение. Воинское звание--полковник.

Награжден 12 правительственными наградами, в том числе орденом Отечественной войны II степени, красной звезды, медалью «За боевые заслуги». Ветеран труда.

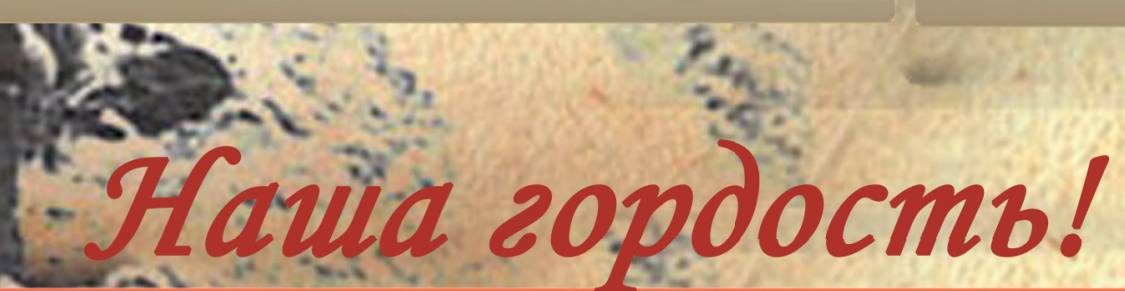

Зубарев Алскссй Гаврилович, 1925 г.р. доцент кафедры организации сельскохозяйственных предприятий.Воевал в составе Ленинградского и 2 -го Белорусского фронтов, 96 тяжелой гаубичной артиллерийской бригады, разведчик, вычислитель - топограф. Воинское звание - сержант. Имеет ранение, контузию. Награжден 9 правительственными наградами, в том числе орденом Красной Звезды, медалями «За боевые заслуги», «За взятие Кенигсберга», «За оборону Ленинграда». Ветеран труда.

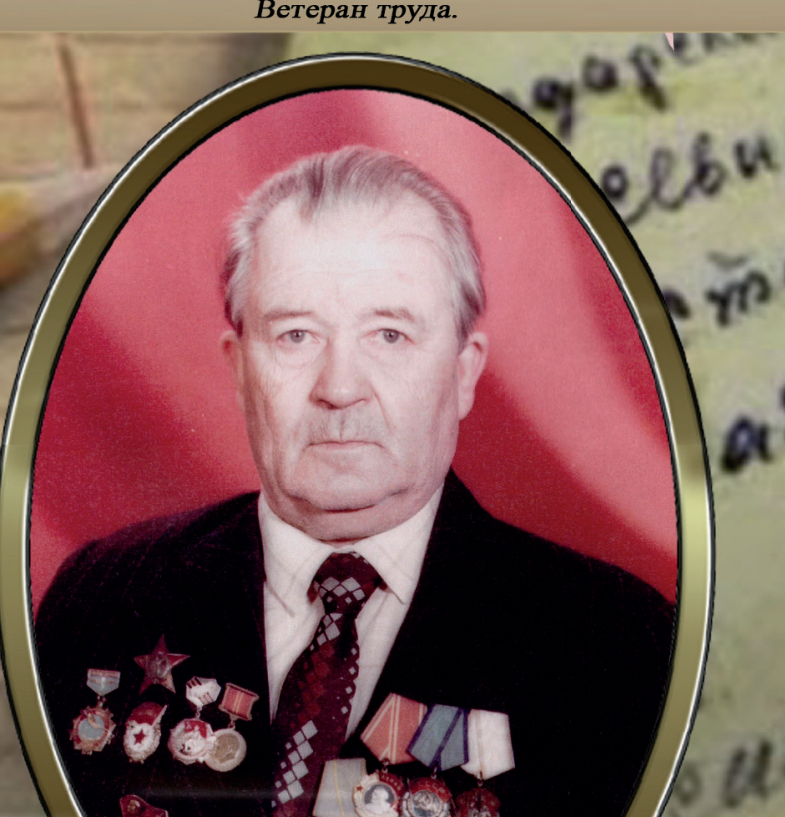

Кирюхин Петр Леонтьевич, 1923 г.р., доцент кафедры философии и научного коммунизма. Воевал в составе Сталинградского, 4- го Украинского, 3-го Белорусского фронтов, механик авиачасти. Воинское звание майор. Имеет ранение под Сталинградом. Награжден 9 правительственными наградами, в том числе орденом Ленина, Красной Звезды, Красного Знамени,

Знак Почета, медалями: «За оборону Сталинграда», «За взятие Кенитсберга».

\section{$1941-1945$}


